\title{
Investigating Bicyclobutane-Triazolinedione Cycloadditions as a Tool for Peptide Modification
}

Brett D. Schwartz, ${ }^{\ddagger}$ Aidan P. Smyth,${ }^{\ddagger}$ Philippe E. Nashar, Michael G. Gardiner, Lara R. Malins* Research School of Chemistry, Australian National University, Canberra, ACT 2601, Australia. *Email: lara.malins@anu.edu.au 
Table of Contents

General Methods $\quad$ S-3

General Procedures $\quad$ S-4

$\begin{array}{ll}\text { Optimization Studies } & \text { S-6 }\end{array}$

$\begin{array}{ll}\text { Competition experiment } & \text { S-8 }\end{array}$

Specific Chemical Transformations $\quad$ S-9

Synthesis of Protected Building Blocks 18 and $23 \quad$ S-24

$\begin{array}{ll}\text { Crystallographic Studies } & \text { S-48 }\end{array}$

$\begin{array}{lr}\text { References } & \text { S-57 }\end{array}$

${ }^{1} \mathrm{H},{ }^{13} \mathrm{C}$ and/or 2D NMR Spectra of Compounds S-58 


\section{General Methods}

Melting points were measured using an SRS Optimelt automated melting point system and are uncorrected. Optical rotations were measured in the solvent specified using a Rudolph Research Analytical Autopol I Automatic Polarimeter (sodium D line, $589 \mathrm{~nm}$ ) at $22{ }^{\circ} \mathrm{C}$. Unless otherwise specified, proton $\left({ }^{1} \mathrm{H}\right)$ and carbon $\left({ }^{13} \mathrm{C}\right) \mathrm{NMR}$ spectra were recorded at $18{ }^{\circ} \mathrm{C}$ in $\mathrm{CDCl}_{3}$ (treated with $\mathrm{K}_{2} \mathrm{CO}_{3}$ and then stored over $4 \AA$ molecular sieves) or in $\mathrm{D}_{2} \mathrm{O}(99.9$ atom \% D) on Bruker Ascend 400 , $600,700 \mathrm{MHz}$ or Varian MR400 $400 \mathrm{MHz}$ spectrometers. Chemical shifts are recorded in parts per million $(\mathrm{ppm})$ downfield from tetramethylsilane $(\delta \mathrm{TMS}=0)$. For ${ }^{1} \mathrm{H}$ NMR spectra, signals arising from the residual protio-forms of the solvent were used as the internal standards. The signal due to residual $\mathrm{CHCl}_{3}$ appearing at $\delta_{\mathrm{H}} 7.26$, partial protio-forms of deuterated benzene at $\delta_{\mathrm{H}} 7.16$, the $\mathrm{HDO}$ resonance at $\delta_{\mathrm{H}} 4.79$, the central resonance at $\delta_{\mathrm{H}} 3.31$ for MeOD and the central resonance at $\delta_{\mathrm{H}} 2.50$ for DMSO- $d_{6}$ were used to reference ${ }^{1} \mathrm{H}$ NMR spectra. The central resonance of the $\mathrm{CDCl}_{3}$ "triplet" appearing at $\delta_{\mathrm{C}} 77.16, \mathrm{C}_{6} \mathrm{D}_{6}$ "triplet" at $\delta_{\mathrm{C}} 128.06, \mathrm{MeOD}$ "septet" at $\delta_{\mathrm{C}} 49.00$ or DMSO- $d_{6}$ "septet" at $\delta_{\mathrm{C}} 39.52$ were used to reference ${ }^{13} \mathrm{C}$ NMR spectra. For ${ }^{13} \mathrm{C}$ NMR spectra recorded in $\mathrm{D}_{2} \mathrm{O}$, ca. $1 \mu \mathrm{L}$ of $\mathrm{CH}_{3} \mathrm{CN}$ was added and the " $\mathrm{CH}_{3}$ " signal arising at $\delta_{\mathrm{C}} 1.47$ was used as a reference. When required for the purposes of differentiation, signals appearing in ${ }^{13} \mathrm{C}$ NMR spectra are reported to two decimal places. ${ }^{1} \mathrm{H}$ NMR data are recorded as follows: chemical shift $\delta(\mathrm{ppm})$ [multiplicity, coupling constant(s) $J(\mathrm{~Hz})$, relative integral] where multiplicity is defined as: $\mathrm{s}=\operatorname{singlet} ; \mathrm{d}=$ doublet; $\mathrm{t}=$ triplet; $\mathrm{q}=$ quartet; $\mathrm{m}=$ multiplet; $\mathrm{b}=$ broad, app. $=$ apparent, obsc. $=$ obscured, or combinations of the above. Structural assignments were made with additional information from gCOSY, gHSQC, and gHMBC experiments.

Infrared spectra were recorded on a Perkin-Elmer UATR Two spectrometer as a thin film or solid. Low-resolution mass spectrometry (LRMS) and high-resolution mass spectrometry (HRMS) were performed using positive or negative mode electrospray ionisation $\left(\mathrm{ESI}^{+/-}\right)$techniques on an Agilent LCMS 6120B, a Micromass ZMD ESI-Quadrupole, a Waters LCT Premier XE, a Thermo-Fischer Scientific Orbitrap Elite ${ }^{\mathrm{TM}}$ Hybrid Ion Trap-Orbitrap or an Orbitrap QExactive mass spectrometer. A VG Fisons Auto-Spec mass spectrometer was used to obtain low- and high-resolution electron impact (EI) mass spectra. Analytical thin layer chromatography (TLC) was performed on aluminum-backed Merck silica gel $60 \mathrm{~F}_{254}$ plates. Eluted plates were visualized using a $254 \mathrm{~nm}$ UV lamp and/or by treatment with a suitable dip followed by heating. These dips included phosphomolybdic acid : ceric sulfate : sulfuric acid (conc.) : water $(37.5 \mathrm{~g}: 7.5 \mathrm{~g}: 37.5 \mathrm{~g}: 720 \mathrm{~mL})$ or potassium permanganate : potassium carbonate : 5\% sodium hydroxide aqueous solution : water $(3 \mathrm{~g}: 20 \mathrm{~g}: 5 \mathrm{~mL}: 300 \mathrm{~mL})$. Flash chromatographic separations were carried out following protocols defined by Still et al. ${ }^{1}$ with Merck silica gel $60(40-63 \mu \mathrm{m})$. THF, $\mathrm{Et}_{2} \mathrm{O}$, and DCM were dried using a Glass Contour solvent purification system that is based upon a technology originally described by Grubbs et al. ${ }^{2}$ Solvent compositions were mixed in the $v / v$ ratios indicated. All solvents and reagents were used as supplied unless otherwise specified. Petroleum spirit (pet. spirit) in the boiling range of $40-60{ }^{\circ} \mathrm{C}$ was used. Reactions were conducted in oven-dried glassware open to the atmosphere unless otherwise specified. $N$-methoxy- $N$-methylbicyclo[1.1.0]butane-1-carboxamide (4) was prepared from $N$-methoxy- $N$ methylcyanoformamide according to our previously published procedures. ${ }^{3}$ For reactions that required heating, the reaction vessel or round bottomed flask was heated in a suitably well-fitting, aluminium dry-heating block attached to a hot-plate magnetic stirrer. Temperature was maintained with a digital thermostat. 


\section{General Procedures}

\section{General procedure A: Preparation of Weinreb amides}

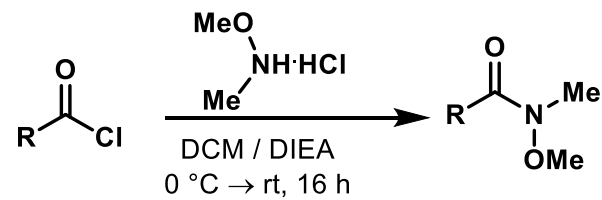

Weinreb amides were prepared according to Ghosh and co-workers: ${ }^{4}$ A magnetically stirred solution of $\mathrm{N}, \mathrm{O}$-dimethylhydroxylamine hydrochloride (1.2 equiv.) and acyl chloride (1.0 equiv.) in DCM $(0.4 \mathrm{M})$ maintained under an atmosphere of nitrogen at $0{ }^{\circ} \mathrm{C}$ was treated with $\mathrm{N}, \mathrm{N}$ diisopropylethylamine (DIEA) (3.0 equiv.) dropwise over five minutes. The cold-bath was removed and stirring maintained at $\mathrm{rt}$ for $16 \mathrm{~h}$. The reaction mixture was treated with $\mathrm{HCl}\left(0.5 \mathrm{M}\right.$ in $\left.\mathrm{H}_{2} \mathrm{O}\right)$ and stirred for $0.25 \mathrm{~h}$ before being extracted with DCM $(3 \times 30 \mathrm{~mL})$. The combined organic phases were washed sequentially with $\mathrm{HCl}(0.5 \mathrm{M}, 2 \times 30 \mathrm{~mL})$, saturated $\mathrm{NaHCO}_{3(\mathrm{aq})}(2 \times 30 \mathrm{~mL})$, brine $(30 \mathrm{~mL})$ and then dried $\left(\mathrm{Na}_{2} \mathrm{SO}_{4(\mathrm{~s})}\right)$ before being concentrated in vacuo to afford the desired products, which required no further purification.

\section{General procedure B: Preparation of [1.1.0]bicyclobutyl ketones}

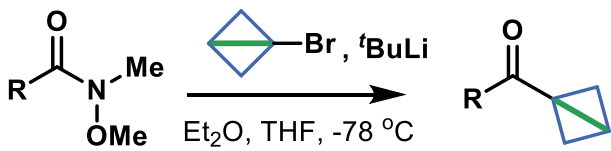

Following a procedure according to Malins and co-workers. ${ }^{3 \mathrm{a}}$ A magnetically stirred solution of 1-

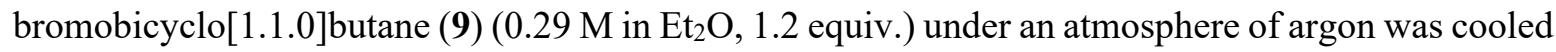
to $-78{ }^{\circ} \mathrm{C}\left(\mathrm{CO}_{2(\mathrm{~s})} /\right.$ acetone), then treated dropwise with ${ }^{t} \mathrm{BuLi}$ (2.4 equiv.) over the course of 10 minutes. The reaction mixture was stirred vigorously for $0.5 \mathrm{~h}$, at which point it was treated dropwise with the desired Weinreb amide ( $0.20 \mathrm{M}$ in anhydrous THF, 1.0 equiv.). The solution was stirred vigorously for a further 5 minutes, then quenched with a saturated $\mathrm{NaHCO}_{3 \text { (aq) }}$ solution (ca. 20 $\mathrm{mL}$ ) containing ice (ca. $10 \mathrm{~g})$. The reaction mixture was extracted using $\mathrm{Et}_{2} \mathrm{O}(3 \times 10 \mathrm{~mL})$ and the combined organic phases were washed with brine $(20 \mathrm{~mL})$, dried $\left(\mathrm{Na}_{2} \mathrm{SO}_{4(\mathrm{~s})}\right)$, then concentrated via rotary evaporation to afford a crude residue. Purification by flash chromatography, in the solvents specified, afforded the desired ketone. 


\section{General procedure C: Preparation of semicarbazides}<smiles>O=C=Nc1ccc(Br)cc1</smiles><smiles>CCOC(=O)NN</smiles>

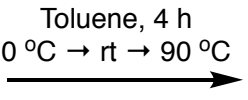<smiles>CCOC(=O)NNC(=O)Nc1ccc(Br)cc1</smiles>

Procedure adapted from Zolfigol and co-workers. ${ }^{5}$ A magnetically stirred solution of ethyl carbazate (S-1, 1.0 equiv.) in toluene $(0.9 \mathrm{M})$ maintained under an atmosphere of nitrogen was cooled to $0{ }^{\circ} \mathrm{C}$, then isocyanate (1.0 equiv.) was added dropwise over $5 \mathrm{~min}$. The cold-bath was removed and after $2 \mathrm{~h}$, the mixture was heated to $90^{\circ} \mathrm{C}$ and stirring maintained for an additional $2 \mathrm{~h}$. The mixture was cooled to room temperature and the precipitate collected by vacuum filtration. The solids were then washed with cold toluene to afford the desired semicarbazide as a powder.

\section{General procedure D: Preparation of 4-substituted urazoles}<smiles>CCOC(=O)NNC(=O)Nc1ccc([Tl])cc1</smiles><smiles>O=c1[nH][nH]c(=O)n1-c1ccc([TlH])cc1</smiles>

Procedure adapted from Zolfigol and co-workers. ${ }^{5}$ A magnetically stirred solution of semicarbazide (1.0 equiv.) under an atmosphere of nitrogen was treated with aqueous $\mathrm{KOH}$ (4.0 M, 2.0 equiv.). The mixture was heated under reflux for $1.5 \mathrm{~h}$ and then the mixture was filtered, whilst warm, and the filtrate collected. The filtrate was then acidified to $\mathrm{pH} 1$ using aqueous $\mathrm{HCl}(4.0 \mathrm{M})$ leading to precipitation of the product. The crude product was then collected by vacuum filtration and washed with cold water, affording the desired urazole as a powder.

\section{General procedure E: Preparation of 1,2,4-triazoline-3,5-diones (TADs)}<smiles>[R]c1ccc(-n2c(=O)[nH][nH]c2=O)cc1</smiles><smiles>[R]c1ccc(N2C(=O)N=NC2=O)cc1</smiles> 
Procedure adapted from Zolfigol and co-workers. ${ }^{5}$ A magnetically stirred solution of urazole (1.0 equiv) in $\mathrm{DCM}(0.1 \mathrm{M})$ was charged with $\operatorname{KBr}(0.2$ equiv) then Oxone ( 1.15 equiv.) The mixture was stirred vigorously and drops of water $(\sim 3$ per mmol of urazole) were added. After $0.33 \mathrm{~h}$, the mixture was filtered and the filtrate collected. DCM was removed via rotary evaporation, affording the desired 1,2,4-triazoline-3,5-dione, which was used without further purification.

\section{General procedure F: Preparation of BCB-TAD cycloadducts}<smiles>[R]C(=O)C12CC1C2</smiles>

Procedure adapted from Amey \& Smart. ${ }^{6}$ A magnetically stirred solution of acyl BCB (1.0 equiv.) in THF (0.06 M with respect to the acyl BCB) at $\mathrm{rt}$ was charged with TAD (2.0 equiv.). After $16 \mathrm{~h}$, the solvent was removed via rotary evaporation and the resulting crude residue was purified via flash column chromatography using the specified solvent gradient to afford the desired cycloadduct.

\section{Optimization Studies}

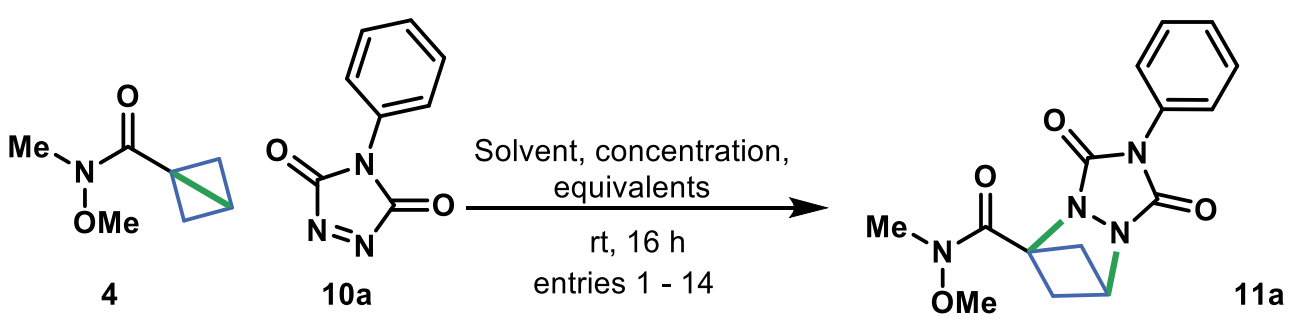

The optimization of the cycloaddition reaction to form 11a (water sensitivity, equivalents, solvent and concentration) employed the cycloaddition of BCB carboxamide $\mathbf{4}$ and PTAD (10a) as a model reaction (Table 1 - entries 1 to 14). All reactions were run on a $0.11 \mathrm{mmol} \mathrm{scale,} \mathrm{with} \mathrm{the} \mathrm{exception}$ of entries 9 and 10 (20 $\mu \mathrm{mol}$, no observed product). Reactions were conducted according to General Procedure F, with equivalents of TAD, solvent and concentration adjusted appropriately. After $4 \mathrm{~h}$, solvents were removed and the cycloadduct was purified by flash column chromatography (silica, 1:1 $\left.v / v \mathrm{Et}_{2} \mathrm{O}: \mathrm{DCM}\right)$.

\section{Cycloaddition of 4 and 10b under various light conditions}<smiles>CON(C)C(=O)C12CC1C2</smiles>

4<smiles>COc1ccc(N2C(=O)N=NC2=O)cc1</smiles>

$10 b$<smiles>COc1ccc(-n2c(=O)n3n(c2=O)C2(C(=O)N(C)OC)CC3C2)cc1</smiles>

11b 
Magnetically stirred solutions of $\mathbf{1 0 b}$ (1.0 equiv., $0.22 \mathrm{mmol}, 0.06 \mathrm{M}$ in THF) in quartz tubes were subjected to three lighting conditions: 1) wrapped in aluminium foil for the absence of light; 2) left exposed to fume hood light (cool-white LED) for ambient light; and 3) placed in a black box and exposed to a UVGL-58 handheld lamp $\left(\lambda_{\max }=254 \mathrm{~nm}\right)$ for UV irradiation. BCB carboxamide 4 (1.0 equiv., $0.11 \mathrm{mmol}$ ) was then added to each flask, with care taken not to disrupt the relevant lighting conditions. After $4 \mathrm{~h}$, cycloadduct was observed in each reaction and was isolated using flash chromatography $\left(1: 1 \mathrm{Et}_{2} \mathrm{O}: \mathrm{DCM}\right)$ (yields: absence of light $=43 \%$, ambient $\left.=44 \%, \mathrm{UV}=43 \%\right)$.

Table 1: Optimisation (water sensitivity, equivalents, solvent and concentration) for the cycloaddition of $\mathrm{BCB}$ carboxamide 4 and PTAD (10a) - entries 1 to 14. Cycloaddition of $\mathbf{4}$ and $\mathbf{1 0 b}$ under various light conditions - entries 15 to 17 .

\begin{tabular}{|c|c|c|c|c|c|c|}
\hline $\begin{array}{l}\text { Entry } \\
\text { No. }\end{array}$ & $\begin{array}{l}\text { Anhydrous } \\
\text { conditions }^{\dagger}\end{array}$ & $\begin{array}{c}\text { Equiv. } \\
\text { of } 10 \mathrm{a}\end{array}$ & Solvent & $\begin{array}{c}\text { Conc. (M) } \\
\text { of } 4\end{array}$ & $\begin{array}{l}\text { Cycloadduct } \\
\text { Isolated Yield }\end{array}$ & Lighting \\
\hline$\overline{c 1}$ & Yes & 1 & "THF & 0.06 & $31 \%$ & Ambient \\
\hline 2 & No & 1 & THF & 0.06 & $30 \%$ & Ambient \\
\hline 3 & No & 2 & THF & 0.06 & $46 \%$ & Ambient \\
\hline 4 & No & 3 & THF & 0.06 & $45 \%$ & Ambient \\
\hline 5 & No & 2 & $\overline{\mathrm{DCM}}$ & 0.06 & $42 \%$ & Ambient \\
\hline 6 & No & 2 & $\mathrm{CDCl}_{3}{ }^{\dagger \dagger}$ & 0.06 & $50 \%$ & Ambient \\
\hline 7 & No & 2 & Toluene & 0.06 & $46 \%$ & Ambient \\
\hline 8 & No & 2 & $1: 1 \mathrm{CDCl}_{3}^{\dagger \dagger}:$ toluene & 0.06 & $45 \%$ & Ambient \\
\hline 9 & No & 1 & $\mathrm{H}_{2} \mathrm{O}$ & 0.06 & Not observed & Ambient \\
\hline 10 & No & 1 & 1:1 $\mathrm{H}_{2} \mathrm{O}: \mathrm{MeCN}$ & 0.06 & Not observed & Ambient \\
\hline 11 & No & 2 & $\mathrm{MeCN}$ & 0.06 & $46 \%$ & Ambient \\
\hline 12 & No & 2 & THF & 0.0024 & $45 \%$ & Ambient \\
\hline 13 & No & 2 & THF & 0.012 & $46 \%$ & Ambient \\
\hline 14 & No & 2 & THF & 0.3 & $47 \%$ & Ambient \\
\hline 15 & No & $2(10 b)$ & THF & 0.06 & $44 \%$ & Ambient \\
\hline 16 & No & $2(\mathbf{1 0 b})$ & THF & 0.06 & $43 \%$ & Dark \\
\hline 17 & No & $2(10 b)$ & THF & 0.06 & $43 \%$ & $254 \mathrm{~nm}$ \\
\hline
\end{tabular}

${ }^{\dagger}$ Anhydrous conditions involved a pre-dried reaction vessel, dry solvent and an atmosphere of argon.

${ }^{\dagger} \mathrm{CDCl}_{3}$ was base-treated with $\mathrm{K}_{2} \mathrm{CO}_{3(\mathrm{~s})}$ to preclude $\mathrm{BCB}$ decomposition from various amounts of concomitant hydrogen chloride. 


\section{Competition experiment between TAD 10b and TAD 10c with BCB carboxamide 4}<smiles>COc1ccc(N2C(=O)N=NC2=O)cc1</smiles>

A magnetically stirred solution of $\mathbf{1 0 b}(111 \mathrm{mg}, 0.54 \mathrm{mmol})$ and $\mathbf{1 0 c}(119 \mathrm{mg}, 0.54 \mathrm{mmol})$ in THF $(2 \mathrm{~mL})$ was treated in one portion with BCB carboxamide $4(38 \mathrm{mg}, 0.27 \mathrm{mmol})$ in THF $(2.5 \mathrm{~mL})$. After $0.5 \mathrm{~h}$ the bright-red coloured reaction mixture was quenched by pouring into water $(20 \mathrm{~mL})$ and the mixture shaken vigorously for 1 minute. The ensuing light-brown coloured mixture was then extracted with EtOAc $(15 \mathrm{~mL})$ and DCM $(15 \mathrm{~mL})$ the combined organic phases were dried $\left(\mathrm{Na}_{2} \mathrm{SO}_{4(\mathrm{~s})}\right)$ and concentrated under reduced pressure to afford a thick, brown oil which was analysed directly, without further purification, by ${ }^{1} \mathrm{H}$ NMR $(700 \mathrm{MHz})$.
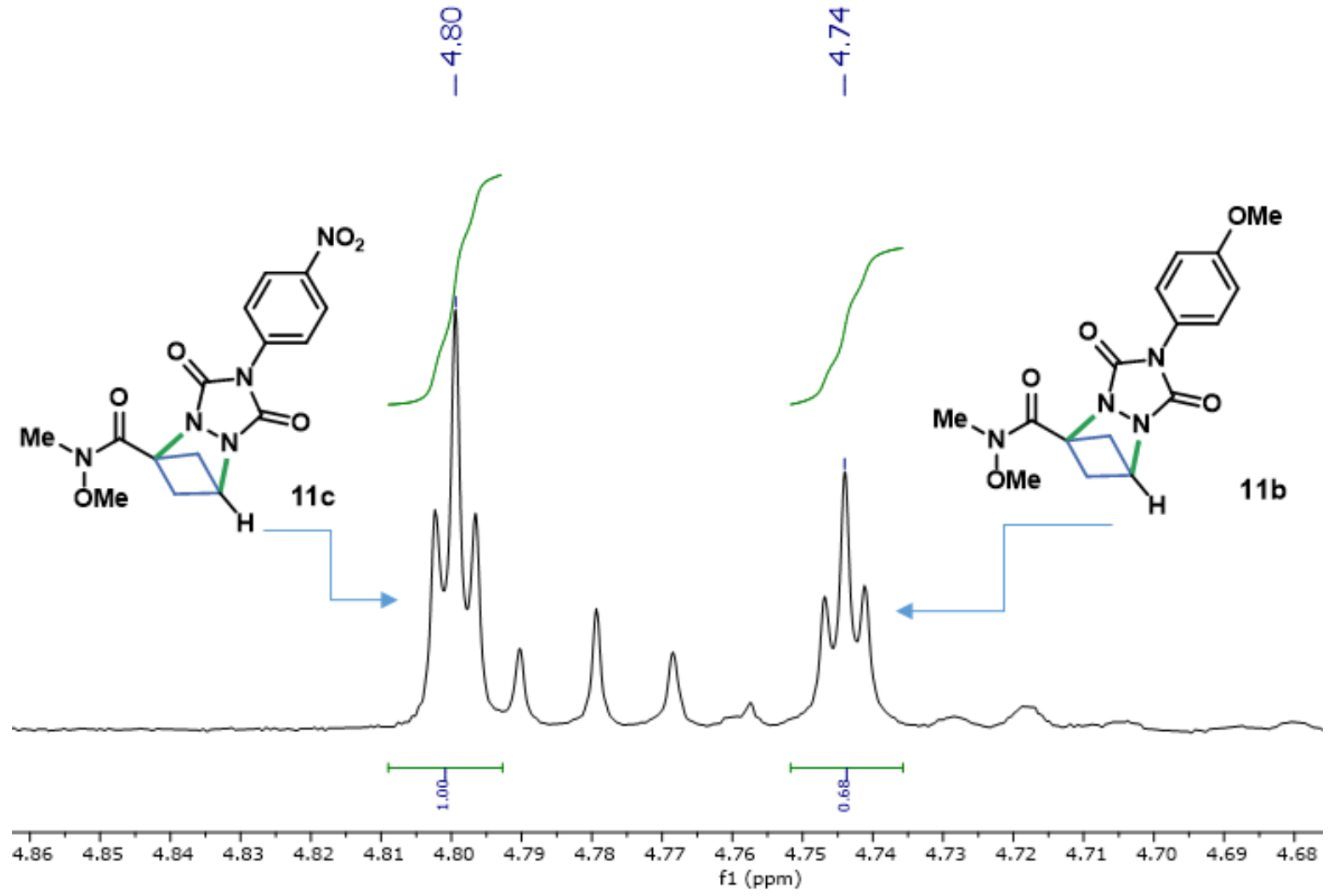

Figure 1. ${ }^{1} \mathrm{H}$ NMR analysis $(700 \mathrm{MHz})$ of the crude reaction material obtained 


\section{Specific Chemical Transformations}

\section{Ethyl carbazate $\mathbf{S - 1}$}<smiles>CCOC(=O)NN</smiles>

Procedure adapted from Zolfigol and co-workers. ${ }^{5}$ A magnetically stirred solution of diethyl carbonate $(12.9 \mathrm{~mL}, 107 \mathrm{mmol})$ and hydrazine monohydrate $(5.06 \mathrm{~mL}, 101 \mathrm{mmol})$ was heated to $50{ }^{\circ} \mathrm{C}$. After $0.33 \mathrm{~h}$ the mixture was cooled to $\mathrm{rt}$ and stirring maintained for $30 \mathrm{~h}$. Volatiles were removed by short-path distillation $(\sim 1 \mathrm{mmHg})$ to afford ethyl carbazate $\mathbf{S - 1}(10.0 \mathrm{~g} \mathrm{95 \% )}$ as a white crystalline mass.

${ }^{1}$ H NMR (400 MHz, CDCl 3 ) $\delta 6.11($ br s, $1 \mathrm{H}), 4.15$ (q, $\left.J=7.2 \mathrm{~Hz}, 2 \mathrm{H}\right), 3.70$ (br s, 2H), 1.24 (t, $J=$ $7.1 \mathrm{~Hz}, 3 \mathrm{H})$.

${ }^{13}$ C NMR (101 MHz, $\left.\mathbf{C D C l}_{3}\right) \delta 159.0,61.6,14.6$.

LRMS (ESI $\left.{ }^{+}\right): m / z$ (rel. int.) $105(100)[\mathrm{M}+\mathrm{H}]^{+}$.

IR: $\mathrm{V}_{\max }=3317,3230,1706,1651,1527,1277,1066,697 \mathrm{~cm}^{-1}$.

Preparation of benzyl bicyclo[1.1.0]butane-1-carboxylate $\mathbf{1}$

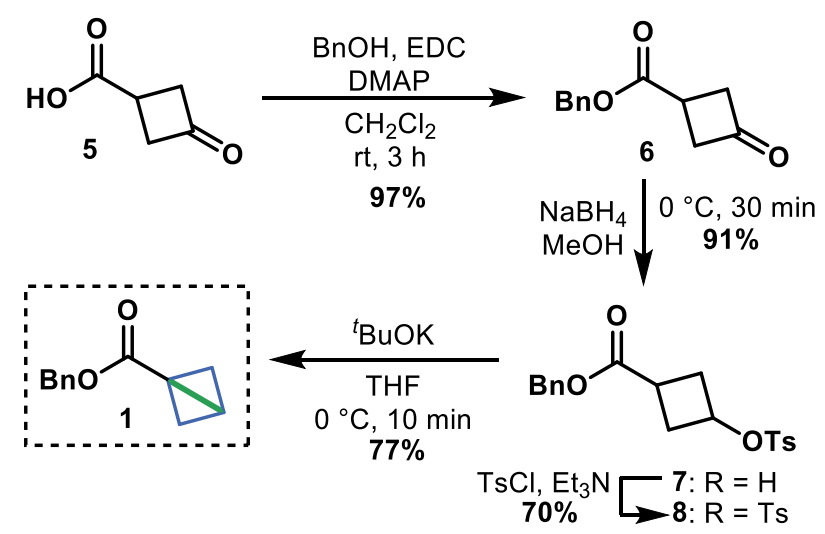

Benzyl 3-oxocyclobutane-1-carboxylate 6

Procedure adapted from Majima and Yamano. ${ }^{7}$ A magnetically stirred solution of 3-oxocyclobutane1-carboxylic acid $(1.0 \mathrm{~g}, 8.8 \mathrm{mmol})$ in DCM $(44 \mathrm{~mL}, 0.2 \mathrm{M})$ maintained under an atmosphere of nitrogen, was charged with 1-ethyl-3-(3-dimethylaminopropyl)carbodiimide hydrochloride (EDC) 
(1.85 g, $9.6 \mathrm{mmol})$, benzyl alcohol ( $0.91 \mathrm{~mL}, 8.8 \mathrm{mmol})$, and DMAP (0.21 g, $1.8 \mathrm{mmol})$. The reaction mixture was left stirring for $3 \mathrm{~h}$. DCM $(20 \mathrm{~mL})$ was added to the reaction mixture, which was then quenched with a saturated aqueous $\mathrm{NH}_{4} \mathrm{Cl}$ solution $(50 \mathrm{~mL})$. The reaction was extracted with $\mathrm{DCM}$ $(2 \times 50 \mathrm{~mL})$. The combined organic phase was dried $\left(\mathrm{Na}_{2} \mathrm{SO}_{4(\mathrm{~s})}\right)$, then the solvent removed via rotary evaporation to yield 6 as a light brown oil (1.75 g, 97\%), which required no further purification. Spectral data were consistent with those reported. ${ }^{8}$

${ }^{1}$ H NMR (400 MHz, CDCl $) \delta 7.40-7.34(\mathrm{~m}, 5 \mathrm{H}), 5.20$ (s, 2H), $3.49-3.39$ (m, 2H), $3.34-3.24$ $(\mathrm{m}, 3 \mathrm{H})$.

LRMS (ESI $\left.{ }^{+}\right): m / z$ (rel. int.) $227(100)[\mathrm{M}+\mathrm{Na}]^{+}$.

\section{Benzyl 3-hydroxycyclobutane-1-carboxylate 7}

Procedure adapted from Gryko and coworkers. ${ }^{9}$ A magnetically stirred solution of ketone 6 (1.00 g, $4.90 \mathrm{mmol})$ in $\mathrm{MeOH}(17 \mathrm{~mL}, 0.3 \mathrm{M})$ was cooled to $0{ }^{\circ} \mathrm{C}$ (ice/water bath). The reaction mixture was charged with $\mathrm{NaBH}_{4}(93 \mathrm{mg}, 2.45 \mathrm{mmol})$ and stirred at $0{ }^{\circ} \mathrm{C}$ (ice/water bath) for $0.5 \mathrm{~h}$, then quenched with a saturated aqueous $\mathrm{NH}_{4} \mathrm{Cl}$ solution $(50 \mathrm{~mL})$. The reaction was extracted using DCM $(3 \times 50 \mathrm{~mL})$ and the combined organic phase was washed with brine $(50 \mathrm{~mL})$, dried with $\mathrm{Na}_{2} \mathrm{SO}_{4(\mathrm{~s})}$, then the solvent removed via rotary evaporation to yield 7 as a light-yellow oil (915 $\mathrm{mg}, 91 \%)$ a portion of which was used without further purification in the tosylation reaction detailed below. Spectral data were consistent with those reported. ${ }^{10}$

${ }^{1} \mathbf{H}$ NMR (400 MHz, $\left.\mathbf{C D C l}_{3}\right) \delta 7.39-7.30(\mathrm{~m}, 5 \mathrm{H}), 5.12(\mathrm{~s}, 2 \mathrm{H}), 4.24-4.15(\mathrm{~m}, 1 \mathrm{H}), 2.71-2.56$ (m, 3H), $2.27-2.13(\mathrm{~m}, 2 \mathrm{H}), 1.92-1.70$ (br m, OH).

LRMS (ESI $\left.{ }^{+}\right): m / z$ (rel. int.) $229(100)[\mathrm{M}+\mathrm{Na}]^{+}$.

\section{Benzyl 3-(tosyloxy)cyclobutane-1-carboxylate $\mathbf{8}$}

Procedure adapted from Gryko and coworkers. ${ }^{9}$ A magnetically stirred solution of alcohol $(7,0.50 \mathrm{~g}$, $2.4 \mathrm{mmol})$, maintained under an atmosphere of nitrogen, in DCM $(2.5 \mathrm{~mL}, 1.0 \mathrm{M})$ was cooled to $0{ }^{\circ} \mathrm{C}$ (ice/water bath). The reaction mixture was charged with 4-toluenesulfonyl chloride $(0.60 \mathrm{~g}$, $3.2 \mathrm{mmol}), \mathrm{Et}_{3} \mathrm{~N}(0.44 \mathrm{~mL}, 3.2 \mathrm{mmol})$, and DMAP ( $\left.30 \mathrm{mg}, 0.24 \mathrm{mmol}\right)$. The reaction was warmed to room temperature and left stirring for $3 \mathrm{~h}$. DCM $(20 \mathrm{~mL})$ was added to the reaction mixture, then water $(40 \mathrm{~mL})$. The organic phase was washed with brine $(50 \mathrm{~mL})$, dried with $\mathrm{Na}_{2} \mathrm{SO}_{4(\mathrm{~s})}$, then the solvent removed via rotary evaporation to afford a residue which was purified by flash chromatography (silica, 1:10 v/v EtOAc:pet. spirit). Concentration of the appropriate fractions provided $\mathbf{8}$ as a colourless solid (611 $\mathrm{mg}, 70 \%)$.

${ }^{1}$ H NMR (400 MHz, $\left.\mathbf{C D C l}_{3}\right) \delta 7.80-7.76(\mathrm{~m}, 2 \mathrm{H}), 7.39-7.29(\mathrm{~m}, 7 \mathrm{H}), 5.09$ (s, 2H), $4.78-4.70$ (m, $1 \mathrm{H}), 2.72-2.60(\mathrm{~m}, 1 \mathrm{H}), 2.54-2.39(\mathrm{~m}, 4 \mathrm{H}), 2.45(\mathrm{~s}, 3 \mathrm{H})$.

${ }^{13}$ C NMR (101 MHz, CDCl $) \delta 173.1,145.1,135.7,134.0,130.0,128.8,128.5,128.4,128.0,69.7$, $66.9,34.3,29.8,21.8$. 
LRMS (ESI $\left.{ }^{+}\right): m / z$ (rel. int.) $383(100)[\mathrm{M}+\mathrm{Na}]^{+}$.

Benzyl bicyclo[1.1.0]butane-1-carboxylate 1

Procedure adapted from Gryko and coworkers. ${ }^{9}$ A magnetically stirred solution of tosylate $(\mathbf{8}, 0.5 \mathrm{~g}$, $1.4 \mathrm{mmol}, 1.0$ equiv.), maintained under an atmosphere of nitrogen, in THF ( $7 \mathrm{~mL}, 0.2 \mathrm{M})$ was cooled to $0{ }^{\circ} \mathrm{C}$ (ice/water bath). The reaction mixture was charged with ${ }^{t} \mathrm{BuOK}(2 \mathrm{~mL}, 1.5 \mathrm{mmol}, 0.73 \mathrm{M}$ in THF). The reaction mixture was left stirring for $10 \mathrm{~min}$, then quenched with a saturated aqueous $\mathrm{NH}_{4} \mathrm{Cl}$ solution $(10 \mathrm{~mL})$. The reaction mixture was extracted with DCM $(3 \times 20 \mathrm{~mL})$ and the combined organic phase was dried with $\mathrm{Na}_{2} \mathrm{SO}_{4(\mathrm{~s})}$, and solvent removed via rotary evaporation to provide a crude oil. The ensuing residue was then subjected to purification by flash chromatography (silica, 1:20 v/v Et $2 \mathrm{O}$ :pentane) to yield 1 as a colourless solid (202 $\mathrm{mg}, 77 \%$ ). Spectral data were consistent with those reported. ${ }^{11}$

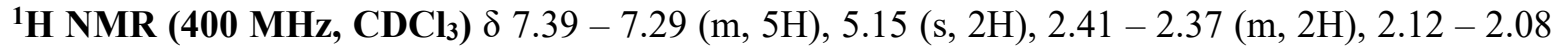
$(\mathrm{m}, 1 \mathrm{H}), 1.19-1.16(\mathrm{~m}, 2 \mathrm{H})$.

LRMS (ESI $\left.{ }^{+}\right): m / z$ (rel. int.) $211(100)[\mathrm{M}+\mathrm{Na}]^{+}$.

$N$-methoxy-N-methyl-hexanamide $\mathbf{S - 2}$<smiles>CCCCCC(=O)N(C)OC</smiles>

Prepared according to General Procedure A on a $35 \mathrm{mmol}$ scale. Reaction of $\mathrm{N}, \mathrm{O}$-dimethyl hydroxylamine hydrochloride $(2.56 \mathrm{~g}, 42.0 \mathrm{mmol})$ with $n$-hexanoyl chloride $(4.89 \mathrm{~mL}, 35 \mathrm{mmol})$ in the presence of DIEA $(18.3 \mathrm{~mL}, 105 \mathrm{mmol})$ and DCM $(90 \mathrm{~mL})$ afforded $N$-methoxy- $N$-methylhexanamide (S-2) (4.90 g, 89\%) as a brown oil following aqueous workup. Spectral data were consistent with those reported. ${ }^{12}$

${ }^{1} \mathrm{H}$ NMR (400 MHz, CDCl $) \delta 3.68(\mathrm{~s}, 3 \mathrm{H}), 3.18(\mathrm{~s}, 3 \mathrm{H}), 2.43-2.39(\mathrm{t}, J=7.6 \mathrm{~Hz}, 2 \mathrm{H}), 1.64-1.61$ (m, 2H), 1.36-1.29 (m, 4H), $0.90(\mathrm{t}, J=6.9 \mathrm{~Hz}, 3 \mathrm{H})$.

$N$-methoxy-N-methyl-benzamide $\mathbf{S - 3}$<smiles>CON(C)C(=O)c1ccccc1</smiles>

Prepared according to general procedure $\mathrm{A}$ on a $35 \mathrm{mmol}$ scale. Reaction of $\mathrm{N}, \mathrm{O}$-dimethyl hydroxylamine hydrochloride $(2.56 \mathrm{~g}, 42.0 \mathrm{mmol})$ with benzoyl chloride $(4.06 \mathrm{~mL}, 35 \mathrm{mmol})$ in the presence of DIEA $(18.3 \mathrm{~mL}, 105 \mathrm{mmol})$ and DCM $(90 \mathrm{~mL})$ afforded $N$-methoxy- $N$-methylbenzamide (S-3) (5.6 g, $34 \mathrm{mmol}, 97 \%$ ) as a brown oil following aqueous workup. Spectral data were consistent with those reported. ${ }^{3 b}$ 
${ }^{1} \mathrm{H}$ NMR (400 MHz, CDCl $) \delta 7.69-7.65(\mathrm{~m}, 2 \mathrm{H}), 7.48-7.38(\mathrm{~m}, 3 \mathrm{H}), 3.56(\mathrm{~s}, 3 \mathrm{H}), 3.36(\mathrm{~s}, 3 \mathrm{H})$.

${ }^{13}$ C NMR (101 MHz, $\left.\mathbf{C D C l}_{3}\right) \delta 170.1,134.3,130.7,128.3,128.1,61.1,33.9$.

1-(Bicyclo[1.1.0]butan-1-yl)hexan-1-one 2

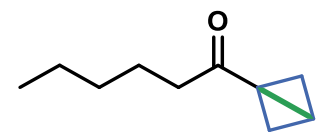

Prepared according to General Procedure B on a $2.20 \mathrm{mmol}$ scale. Reaction of Weinreb amide S-2 (11.0 mL, 2.20 mmol, 0.20 M in THF) with 1-bromobicyclo[1.1.0]butane ${ }^{3 \mathrm{a}}(9.10 \mathrm{~mL}, 2.64 \mathrm{mmol}$, $0.29 \mathrm{M}$ in diethyl ether) and ${ }^{t} \mathrm{BuLi}(3.52 \mathrm{~mL}, 5.28 \mathrm{mmol}, 1.5 \mathrm{M}$ in pentane) followed by flash chromatography (silica, 1:5 v/v Et $2 \mathrm{O}$ :pentane) yielded ketone 2 as a colourless oil (255 $\mathrm{mg}, 76 \%$ ).

$\mathbf{R}_{f}=0.4\left(1: 5 v / v \mathrm{Et}_{2} \mathrm{O}:\right.$ pentane $)$.

${ }^{1} \mathbf{H}$ NMR (400 MHz, CDCl$)$ ) $\delta$ 2.44-2.43 (m, 2H), 2.41 (t, $\left.J=7.5 \mathrm{~Hz}, 2 \mathrm{H}\right), 2.15-2.12(\mathrm{~m}, 1 \mathrm{H}), 1.65-$ $1.57(\mathrm{~m}, 2 \mathrm{H}), 1.35-1.25(\mathrm{~m}, 4 \mathrm{H}), 1.20-1.18(\mathrm{~m}, 2 \mathrm{H}), 0.89$ (t, $J=6.9 \mathrm{~Hz}, 3 \mathrm{H})$.

${ }^{13}$ C NMR (101 MHz, $\left.\mathbf{C D C l}_{3}\right) \delta$ 207.1, 39.0, 35.8, 31.6, 24.4, 22.6, 19.7, 18.5, 14.1.

HRMS $\left(\mathrm{EI}^{+}\right)$: calc'd for $\mathrm{C}_{10} \mathrm{H}_{16} \mathrm{O}^{+}[\mathrm{M}]^{+*}:$ 152.1201, found: 152.1206 .

IR: $\mathrm{V}_{\max }=2957,2933,2872,1669,1403,836 \mathrm{~cm}^{-1}$.

Bicyclo[1.1.0]butan-1-yl(phenyl)methanone $\mathbf{3}$<smiles>O=C(c1ccccc1)C1CC1</smiles>

Prepared according to General Procedure B on a $2.10 \mathrm{mmol}$ scale. Reaction of Weinreb amide $\mathbf{S}-\mathbf{3}$ (10.5 mL, $2.10 \mathrm{mmol}, 0.20 \mathrm{M}$ in THF) with 1-bromobicyclo[1.1.0]butane ${ }^{3 \mathrm{a}}$ (8.69 mL, $2.52 \mathrm{mmol}$, $0.29 \mathrm{M}$ in diethyl ether) and ${ }^{t} \mathrm{BuLi}(3.36 \mathrm{~mL}, 5.04 \mathrm{mmol}, 1.5 \mathrm{M}$ in pentane) followed by purification by flash chromatography (silica, 1:5 v/v Et $2 \mathrm{O}$ :pentane) yielded ketone 3 as a colourless oil (240 mg, $1.52 \mathrm{mmol}, 72 \%$ ). Spectral data were consistent with those reported. ${ }^{3 \mathrm{a}}$

${ }^{1}$ H NMR (400 MHz, C6 $\left.\mathbf{D}_{6}\right) \delta$ 7.87-7.83 (m, 2H), 7.14-7.10 (m, 1H), 7.08-7.03 (m, 2H), 2.36-2.33 (m, 2H), 1.63-1.60 (m, 1H), 1.03-1.00 (m, 2H).

${ }^{13} \mathbf{C}$ NMR (101 MHz, $\left.\mathbf{C}_{6} \mathbf{D}_{6}\right)$ one peak obscured by $C_{6} D_{6} \delta 197.7,138.5,132.0,129.1,37.6,20.0$, 16.5 . 


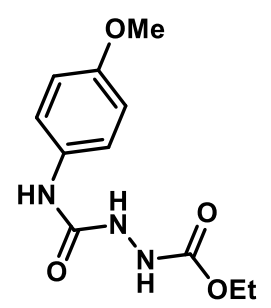

Prepared according to General Procedure $\mathrm{C}$ on a $3.00 \mathrm{mmol}$ scale. Reaction of 1-isocyanato-4methoxybenzene $(447 \mathrm{mg}, 3.00 \mathrm{mmol})$ with ethyl carbazate S-1 $(312 \mathrm{mg}, 3.00 \mathrm{mmol})$ in toluene $(5 \mathrm{~mL})$ followed by vacuum filtration yielded semicarbazide $\mathbf{S}-4$ as a white solid $(0.67 \mathrm{~g}, 87 \%)$.

$\mathbf{R}_{f}=0.6($ EtOAc).

${ }^{1}$ H NMR (400 MHz, DMSO-d 6 ) $\delta 8.87$ (s, 1H), $8.52(\mathrm{~s}, 1 \mathrm{H}), 7.89$ (s, 1H), 7.38-7.32 (m, 2H), 6.86$6.80(\mathrm{~m}, 2 \mathrm{H}), 4.05(\mathrm{q}, J=7.0 \mathrm{~Hz}, 2 \mathrm{H}), 3.70(\mathrm{~s}, 3 \mathrm{H}), 1.19(\mathrm{t}, J=7.0 \mathrm{~Hz}, 3 \mathrm{H})$.

${ }^{13}$ C NMR (101 MHz, DMSO-d $) \delta$ 157.0, 155.8, 154.4, 132.7, 120.3, 113.8, 60.5, 55.1, 14.6.

LRMS (ESI $\left.{ }^{+}\right): m / z$ (rel. int.) $276(15)[\mathrm{M}+\mathrm{Na}]^{+}, 529(100)[2 \mathrm{M}+\mathrm{Na}]^{+}$.

HRMS (ESI ${ }^{+}$): calc'd for $\mathrm{C}_{11} \mathrm{H}_{16} \mathrm{~N}_{3} \mathrm{O}_{4}^{+}[\mathrm{M}+\mathrm{H}]^{+}:$254.1135, found 254.1132.

IR: $\mathrm{V}_{\max }=3320,3279,2979,1739,1683,1599,1506,1236,1032 \mathrm{~cm}^{-1}$.

MP: $168-171{ }^{\circ} \mathrm{C}$.

4-(4-Methoxyphenyl)-1,2,4-triazolidine-3,5-dione S-5<smiles>COc1ccc(-n2c(=O)[nH][nH]c2=O)cc1</smiles>

Prepared according to General Procedure D on a $8.30 \mathrm{mmol}$ scale. Reaction of semicarbazide S-4 ( $2.10 \mathrm{~g}, 8.3 \mathrm{mmol})$ with $\mathrm{KOH}\left(4.15 \mathrm{~mL}, 16.6 \mathrm{mmol}, 4 \mathrm{M}\right.$ in $\left.\mathrm{H}_{2} \mathrm{O}\right)$ followed by acidification and filtration yielded urazole $\mathbf{S}-5$ as a white solid (1.50 g, 87\%).

$\mathbf{R}_{f}=0.2($ EtOAc).

${ }^{1}$ H NMR (400 MHz, DMSO-d d $^{\delta} 10.36$ (br s, 2H), 7.35-7.30 (m, 2H), 7.05-6.99 (m, 2H), 3.78 (s, $3 \mathrm{H})$.

${ }^{13}$ C NMR (101 MHz, DMSO-d $\left.\boldsymbol{d}_{6}\right) \delta$ 158.5, 153.7, 127.7, 124.5, 114.1, 55.4.

HRMS (EI): calc'd for $\mathrm{C}_{9} \mathrm{H}_{9} \mathrm{~N}_{3} \mathrm{O}_{3}[\mathrm{M}]^{+\cdot}: 207.0644$, found 207.0643 . 
IR: $\mathrm{V}_{\max }=3301,3230,1677,1512,1442,1242,787,558 \mathrm{~cm}^{-1}$.

MP: $215-217^{\circ} \mathrm{C}$.

4-(4-Methoxyphenyl)-1,2,4-triazoline-3,5-dione 10b<smiles></smiles>

Prepared according to General Procedure E on a $1.50 \mathrm{mmol}$ scale. Reaction of urazole S-5 $(311 \mathrm{mg}$, $1.50 \mathrm{mmol})$ with $\mathrm{KBr}(36 \mathrm{mg}, 0.30 \mathrm{mmol})$, Oxone $(530 \mathrm{mg}, 1.73 \mathrm{mmol})$, and $\mathrm{H}_{2} \mathrm{O}$ (5 drops) in DCM $(15 \mathrm{~mL})$ followed by filtration then removal of DCM yielded TAD $10 \mathbf{b}$ as a maroon solid $(0.28 \mathrm{~g}$, $1.40 \mathrm{mmol}, 93 \%)$.

$\mathbf{R}_{f}=0.9$ (EtOAc).

${ }^{1}$ H NMR (400 MHz, CDCl $) \delta$ 7.37-7.33 (m, 2H), 7.07-7.02 (m, 2H), $3.86(\mathrm{~s}, 3 \mathrm{H})$.

${ }^{13}$ C NMR (101 MHz, CDCl 3$) \delta 160.3,158.0,125.7,121.9,115.3,55.8$.

HRMS (EI): calc'd for $\mathrm{C}_{9} \mathrm{H}_{7} \mathrm{~N}_{3} \mathrm{O}_{3}[\mathrm{M}]^{+\cdot}:$ 205.0487, found 205.0492 .

IR: $\mathrm{V}_{\max }=1770,1748,1512,1404,1260,1174,1022,676 \mathrm{~cm}^{-1}$.

MP: $127-129^{\circ} \mathrm{C}$.

Ethyl 2-((4-nitrophenyl)carbamoyl)hydrazine-1-carboxylate S-6<smiles>CCOC(=O)NNC(=O)Nc1ccc([N+](=O)[O-])cc1</smiles>

Prepared according to General Procedure C on a 3.10 mmol scale. Reaction of 1-isocyanato-4nitrobenzene (509 mg, $3.10 \mathrm{mmol})$ with ethyl carbazate (S-1) $(323 \mathrm{mg}, 3.10 \mathrm{mmol})$ in toluene $(3.44$ $\mathrm{mL})$ followed by vacuum filtration yielded semicarbazide S-6 $(0.67 \mathrm{~g}, 81 \%)$ as a yellow solid.

$\mathbf{R}_{f}=0.6($ EtOAc) .

${ }^{1}$ H NMR (400 MHz, DMSO-d 6 ) $\delta 9.52$ (br s, 1H), 9.04 (s, 1H), 8.39 (br s, 1H), $8.20-8.14$ (m, 2H), 7.74 (br s, 2H), 4.07 (q, $J=7.2 \mathrm{~Hz}, 2 \mathrm{H}), 1.20$ (t, $J=7.2 \mathrm{~Hz}, 3 \mathrm{H})$. 
${ }^{13}$ C NMR (101 MHz, DMSO-d $\left.\boldsymbol{d}_{6}\right) \delta$ 156.8, 155.1, 146.5, 141.1, 125.0, 117.8, 60.7, 14.5.

LRMS (ESI $\left.{ }^{+}\right): m / z$ (rel. int.) $559(100)[2 \mathrm{M}+\mathrm{Na}]^{+}$.

HRMS (ESI ${ }^{+}$): calc'd for $\mathrm{C}_{10} \mathrm{H}_{13} \mathrm{~N}_{3} \mathrm{O}_{3}{ }^{+}[\mathrm{M}+\mathrm{H}]^{+}: 269.088$, found 269.0877 .

IR: $\mathrm{V}_{\max }=3311,3290,3122,1702,1675,1579,1519,1344,1236,1115,854,624 \mathrm{~cm}^{-1}$.

MP: $208-210{ }^{\circ} \mathrm{C}$.

4-(4-Nitrophenyl)-1,2,4-triazolidine-3,5-dione S-7<smiles>O=c1[nH][nH]c(=O)n1-c1ccc([N+](=O)[O-])cc1</smiles>

Prepared according to General Procedure D on a $5.60 \mathrm{mmol} \mathrm{scale}$. Reaction of semicarbazide S-6 ( $1.50 \mathrm{~g}, 5.60 \mathrm{mmol})$ with $\mathrm{KOH}\left(2.80 \mathrm{~mL}, 11.2 \mathrm{mmol}, 4 \mathrm{M}\right.$ in $\left.\mathrm{H}_{2} \mathrm{O}\right)$ followed by acidification and filtration yielded urazole $\mathrm{S}-7$ as a yellow solid $(1.20 \mathrm{~g}, 5.50 \mathrm{mmol}, 96 \%)$.

$\mathbf{R}_{\boldsymbol{f}}=0.1$ (EtOAc).

${ }^{1}$ H NMR (400 MHz, DMSO-d $\left.\boldsymbol{d}_{6}\right) \delta 10.80$ (s, 2H), 8.38-8.32 (m, 2H), 7.91-7.86 (m, 2H).

${ }^{13}$ C NMR (101 MHz, DMSO-d 6 ) $\delta$ 152.2, 145.5, 138.1, 125.5, 124.1.

LRMS (ESI-): $m / z$ (rel. int.) $221(100)[\mathrm{M}-\mathrm{H}]^{-}, 443(80)[2 \mathrm{M}-\mathrm{H}]^{-}$.

HRMS (EI): calc'd for $\mathrm{C}_{8} \mathrm{H}_{6} \mathrm{~N}_{4} \mathrm{O}_{4}[\mathrm{M}]^{+\bullet}: 222.0389$, found 222.0390 .

IR: $\mathrm{V}_{\max }=3645,3228,1694,1608,1500,1421,1346,850,784,558 \mathrm{~cm}^{-1}$.

MP: $248-250{ }^{\circ} \mathrm{C}$ (decomp.).

4-(4-Nitrophenyl)-1,2,4-triazoline-3,5-dione 10c<smiles></smiles>

Prepared according to General Procedure E on a $17.0 \mathrm{mmol}$ scale. Reaction of urazole S-7 (3.78 g, $17.0 \mathrm{mmol})$ with $\mathrm{KBr}(405 \mathrm{mg}, 3.40 \mathrm{mmol})$, Oxone $(6.01 \mathrm{~g}, 19.6 \mathrm{mmol})$, and $\mathrm{H}_{2} \mathrm{O}(2.0 \mathrm{~mL})$ in DCM S-15 
$(170 \mathrm{~mL})$ followed by filtration then removal of solvent under reduced pressure afforded TAD 10c as a pink solid (3.0 $\mathrm{g}, 80 \%)$.

$\mathbf{R}_{f}=0.75$ (EtOAc).

${ }^{1}$ H NMR (400 MHz, CDCl $) \delta 8.46-8.43(\mathrm{~m}, 2 \mathrm{H}), 7.87-7.85(\mathrm{~m}, 2 \mathrm{H})$.

${ }^{13}$ C NMR (101 MHz, $\left.\mathbf{C D C l}_{3}\right) \delta$ 157.0, 147.6, 135.1, 125.4, 124.1.

MS: A low or high resolution mass spectrum was not able to be obtained on this compound.

IR: $\mathrm{V}_{\max }=2255,1770,1496,1342,851,727 \mathrm{~cm}^{-1}$.

MP: $130-132{ }^{\circ} \mathrm{C}$.

\section{Cycloadduct 11a}<smiles>O=C([O-])C1([N+](=O)[O-])C2CC1n1c(=O)n(-c3ccccc3)c(=O)n12</smiles>

Prepared according to General procedure F on a $0.26 \mathrm{mmol}$ scale. Reaction of BCB 4 ( $38 \mathrm{mg}, 0.26$ mmol) with TAD 10a $(91 \mathrm{mg}, 0.52 \mathrm{mmol})$ in THF $(4.30 \mathrm{~mL})$ followed by purification by flash chromatography (silica, 1:1 v/v Et $\mathrm{t}_{2} \mathrm{O}: \mathrm{DCM}$ ) yielded product 11a as a yellow solid (41 $\mathrm{mg}, 50 \%$ ). Crystallisation of 11a from the slow evaporation of EtOAc afforded crystals which were subjected to single crystal x-ray analysis. The associated data of this experiment, which includes a thermal ellipsoid plot, are disclosed in the Crystallographic Data section of this document.

$\mathbf{R}_{\boldsymbol{f}}=0.53\left(1: 1 v / v \mathrm{Et}_{2} \mathrm{O}: \mathrm{DCM}\right)$.

${ }^{1}$ H NMR (400 MHz, $\left.\mathbf{C D C l}_{3}\right) \delta$ 7.52-7.35 (m, 5H), 4.79-4.76 (m, 1H), 3.85 (s, 3H), $3.32(\mathrm{~s}, 3 \mathrm{H})$, $2.59-2.50(\mathrm{~m}, 2 \mathrm{H}), 2.27-2.19(\mathrm{~m}, 2 \mathrm{H})$.

${ }^{13}$ C NMR (176 MHz, $\left.\mathbf{C D C l}_{3}\right) \delta 164.3,159.5,158.8,131.4,129.3,128.7,125.3,73.5,62.2,59.6$, $43.4,32.7$.

HRMS (ESI ${ }^{+}$): calc'd for $\mathrm{C}_{15} \mathrm{H}_{16} \mathrm{~N}_{4} \mathrm{O}_{4} \mathrm{Na}[\mathrm{M}+\mathrm{Na}]^{+}:$339.1064, found 339.1062.

IR: $V_{\max }=2941,1717,1656,1494,1412,1243 \mathrm{~cm}^{-1}$. MP: $163-165^{\circ} \mathrm{C}$. 
<smiles></smiles>

Prepared according to General procedure F on a $0.23 \mathrm{mmol} \mathrm{scale}$. Reaction of 4 ( $34 \mathrm{mg}, 0.23 \mathrm{mmol}$ ) with TAD $10 \mathrm{~b}(94 \mathrm{mg}, 0.46 \mathrm{mmol})$ in THF $(3.80 \mathrm{~mL})$ followed by purification by flash chromatography (silica, 1:1 v/v Et $\mathrm{t}_{2} \mathrm{O}: \mathrm{DCM}$ ) afforded the desired product $11 \mathbf{b}(39 \mathrm{mg}, 48 \%$ ), as a paleyellow solid. Crystallisation of 11b from the slow evaporation of 1:1 $v / v \mathrm{Et}_{2} \mathrm{O}: \mathrm{DCM}$ afforded crystals which were subjected to single crystal x-ray analysis. The associated data of this experiment, which includes a thermal ellipsoid plot, are disclosed in the Crystallographic Data section of this document.

$\mathbf{R}_{f}=0.5\left(1: 1 v / v \mathrm{Et}_{2} \mathrm{O}: \mathrm{DCM}\right)$.

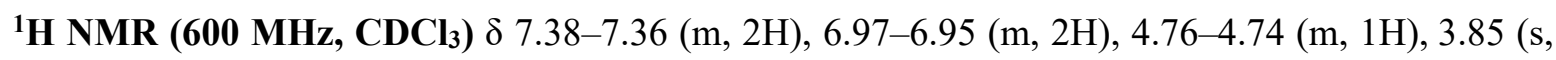
$3 \mathrm{H}), 3.82(\mathrm{~s}, 3 \mathrm{H}), 3.31(\mathrm{~s}, 3 \mathrm{H}), 2.52-2.51(\mathrm{~m}, 2 \mathrm{H}), 2.21-2.20(\mathrm{~m}, 2 \mathrm{H})$.

${ }^{13}$ C NMR (151 MHz, $\left.\mathbf{C D C l}_{3}\right) \delta 164.3,159.9,159.7,159.1,126.9,124.0,114.6,73.5,62.3,59.6$, $55.7,43.4,32.8$.

LRMS $\left(\mathrm{ESI}^{+}\right): m / z$ (rel. int.) $715(100)[2 \mathrm{M}+\mathrm{Na}]^{+}$.

HRMS (ESI ${ }^{+}$): calc'd for $\mathrm{C}_{16} \mathrm{H}_{18} \mathrm{~N}_{4} \mathrm{NaO}_{5}[\mathrm{M}+\mathrm{Na}]^{+}:$369.1175, found 369.1176.

IR: $\mathrm{V}_{\max }=2940,1720,1656,1514,1401,1250,829,438 \mathrm{~cm}^{-1}$.

MP: $161-163{ }^{\circ} \mathrm{C}$.

\section{Cycloadduct 11c}<smiles>CON(C(=O)[O-])C12CC3CC(C1)N3C(=O)N(c1ccc([N+](=O)[O-])cc1)C2=O</smiles>

Prepared according to General procedure F on a 0.29 mmol scale. Reaction of BCB 4 ( $43 \mathrm{mg}, 0.29$ mmol) with TAD 10c $(128 \mathrm{mg}, 0.58 \mathrm{mmol})$ in THF $(4.80 \mathrm{~mL})$ followed by purification by flash chromatography (silica, 1:1 v/v $\mathrm{Et}_{2} \mathrm{O}: \mathrm{DCM}$ ), afforded the desired product 11c (42 $\mathrm{mg}, 41 \%$ ), as a yellow solid. Crystallisation of 11c from the slow evaporation of EtOAc afforded crystals which were 
subjected to single crystal x-ray analysis. The associated data of this experiment, which includes a thermal ellipsoid plot, are disclosed in the Crystallographic Data section of this document.

$\mathbf{R}_{\boldsymbol{f}}=0.53\left(1: 1 \mathrm{Et}_{2} \mathrm{O}: \mathrm{DCM}\right)$.

${ }^{1} \mathbf{H}$ NMR (400 MHz, CDCl $) \delta 8.35-8.30$ (m, 2H), 7.91-7.86 (m, 2H), 4.81 (app. t, $\left.J=1.7 \mathrm{~Hz}, 1 \mathrm{H}\right)$ $3.85(\mathrm{~s}, 3 \mathrm{H}), 3.33(\mathrm{~s}, 3 \mathrm{H}), 2.62-2.54(\mathrm{~m}, 2 \mathrm{H}), 2.28-2.18(\mathrm{~m}, 2 \mathrm{H})$.

${ }^{13}$ C NMR (151 MHz, $\left.\mathbf{C D C l}_{3}\right) \delta 163.9,158.2,157.7,146.8,137.2,124.8,124.6,73.8,62.3,59.9$, $43.8,32.8$.

LRMS (ESI $\left.{ }^{+}\right): m / z$ (rel. int.) $384(100)[\mathrm{M}+\mathrm{Na}]^{+}$.

HRMS (ESI ${ }^{+}$): calc'd for $\mathrm{C}_{15} \mathrm{H}_{15} \mathrm{~N}_{5} \mathrm{NaO}_{6}[\mathrm{M}+\mathrm{Na}]^{+}:$384.0940, found 384.0920.

IR: $\mathrm{V}_{\max }=2941,1724,1657,1524,1387,1344,1103,979,731 \mathrm{~cm}^{-1}$.

MP: $144-146{ }^{\circ} \mathrm{C}$.

Cycloadduct 12a<smiles></smiles>

Prepared according to General procedure F on a $0.26 \mathrm{mmol}$ scale. Reaction of BCB 1 (49 $\mathrm{mg}, 0.26$ mmol) with TAD 10a (91 mg, $0.52 \mathrm{mmol})$ in THF $(4.30 \mathrm{~mL})$ followed by flash column chromatography in 1:100 $\mathrm{Et}_{2} \mathrm{O}$ :DCM yielded 12a as a colourless solid (50 $\mathrm{mg}, 0.14 \mathrm{mmol}, 53 \%$ ).

$\mathbf{R}_{f}=0.4\left(1: 50 v / v \mathrm{Et}_{2} \mathrm{O}: \mathrm{DCM}\right)$.

${ }^{1}$ H NMR (400 MHz, CDCl $)$ ) 8.49 - $7.46(\mathrm{~m}, 4 \mathrm{H}), 7.44-7.34$ (m, 6H), 5.32 (s, 2H), 4.78 (app. t, $J$ $=2.0 \mathrm{~Hz}, 1 \mathrm{H}), 2.63-2.55(\mathrm{~m}, 2 \mathrm{H}), 2.23-2.15(\mathrm{~m}, 2 \mathrm{H})$.

${ }^{13}$ C NMR (101 MHz, $\left.\mathbf{C D C l}_{3}\right) \delta 164.8,159.2,159.0,134.9,131.3,129.4,128.9,128.8,128.7,128.6$, $125.5,72.3,68.2,60.2,43.3$.

LRMS (ESI $\left.{ }^{+}\right): m / z$ (rel. int.) $386(100)[\mathrm{M}+\mathrm{Na}]^{+}$.

HRMS (ESI ${ }^{+}$): calc'd for $\mathrm{C}_{20} \mathrm{H}_{17} \mathrm{~N}_{3} \mathrm{O}_{4} \mathrm{Na}^{+}[\mathrm{M}+\mathrm{Na}]^{+}$386.1111; found 386.1120 .

IR: $\mathrm{V}_{\max }=2924,1721,1404,1327,1135,735,696 \mathrm{~cm}^{-1}$.

MP: $124-125^{\circ} \mathrm{C}$. 
<smiles>COc1ccc(-n2c(=O)n3n(c2=O)C2(C(=O)OCc4ccccc4)CC32)cc1</smiles>

Prepared according to General procedure F on a 0.26 mmol scale. Reaction of BCB 1 (49 mg, 0.26 mmol) with TAD $10 b(107 \mathrm{mg}, 0.52 \mathrm{mmol})$ in THF $(4.30 \mathrm{~mL})$ followed by flash column chromatography in 1:50 v/v Et $2 \mathrm{O}: \mathrm{DCM}$ yielded $\mathbf{1 2 b}$ as a colourless solid (54 mg, $0.14 \mathrm{mmol}, 53 \%$ ).

$\mathbf{R}_{f}=0.25\left(1: 50 \mathrm{Et}_{2} \mathrm{O}: \mathrm{DCM}\right)$.

${ }^{1}$ H NMR (400 MHz, CDCl $) \delta 7.44-7.33(\mathrm{~m}, 7 \mathrm{H}), 6.99-6.95(\mathrm{~m}, 2 \mathrm{H}), 5.32$ (s, 2H), 4.77, (app. t, $J=2.0 \mathrm{~Hz}, 1 \mathrm{H}), 3.83(\mathrm{~s}, 3 \mathrm{H}), 2.63-2.54(\mathrm{~m}, 2 \mathrm{H}), 2.22-2.13(\mathrm{~m}, 2 \mathrm{H})$.

${ }^{13}$ C NMR (101 MHz, CDCl $) \delta$ 164.9, 159.8, 159.6, 159.3, 134.9, 128.8, 128.7, 128.6, 127.1, 123.9, $114.7,72.2,68.2,60.2,55.7,43.2$.

LRMS (ESI $\left.{ }^{+}\right): m / z$ (rel. int.) $416(100)[\mathrm{M}+\mathrm{Na}]^{+}$.

HRMS (ESI'): calc'd for $\mathrm{C}_{21} \mathrm{H}_{19} \mathrm{~N}_{3} \mathrm{O}_{5} \mathrm{Na}^{+}[\mathrm{M}+\mathrm{Na}]^{+}$416.1217; found 416.1221.

IR: $\mathrm{V}_{\max }=2944,1717,1516,1413,1257,1134,827,742 \mathrm{~cm}^{-1}$.

MP: $113-114{ }^{\circ} \mathrm{C}$.

Cycloadduct 12c<smiles>O=C(OCc1ccccc1)C12CC(C1)n1c(=O)n(-c3ccc([N+](=O)[O-])cc3)c(=O)n12</smiles>

Prepared according to General procedure F on a 0.26 mmol scale. Reaction of BCB 1 (49 mg, 0.26 mmol) with TAD 10c $(114 \mathrm{mg}, 0.52 \mathrm{mmol})$ in THF $(4.30 \mathrm{~mL})$ followed by two sequential silica flash column purifications: column 1, 1:100 v/v $\mathrm{Et}_{2} \mathrm{O}$ :DCM, column 2, 2:5 v/v EtOAc: pet. spirit, yielded $\mathbf{1 2 c}$ as a yellow solid (55 $\mathrm{mg}, 52 \%)$.

$\mathbf{R}_{\boldsymbol{f}}=0.4\left(1: 50 v / v \mathrm{Et}_{2} \mathrm{O}: \mathrm{DCM}\right)$.

${ }^{1}$ H NMR (400 MHz, CDCl $) \delta 8.35-8.32(\mathrm{~m}, 2 \mathrm{H}), 7.89-7.84(\mathrm{~m}, 2 \mathrm{H}), 7.44-7.33(\mathrm{~m}, 5 \mathrm{H}), 5.33$ (s, 2H), 4.83 (app. t, $J=2.0 \mathrm{~Hz}, 1 \mathrm{H}), 2.68-2.60(\mathrm{~m}, 2 \mathrm{H}), 2.23-2.16(\mathrm{~m}, 2 \mathrm{H})$.

${ }^{13}$ C NMR (101 MHz, CDCl $) \delta 164.4,157.9,157.8,146.9,137.1,134.7,128.9,128.8,128.6,125.0$, 124.7, 72.6, 68.4, 60.4, 43.7 . 
LRMS (ESI $\left.{ }^{+}\right): m / z$ (rel. int.) $431(100)[\mathrm{M}+\mathrm{Na}]^{+}$.

HRMS (ESI ${ }^{+}$): calc'd for $\mathrm{C}_{20} \mathrm{H}_{16} \mathrm{~N}_{4} \mathrm{O}_{6} \mathrm{Na}^{+}[\mathrm{M}+\mathrm{Na}]^{+}$431.0962; found 431.0967 .

IR: $\mathrm{V}_{\max }=2924,1725,1599,1521,1405,1326,1134,700 \mathrm{~cm}^{-1}$.

MP: $144-146^{\circ} \mathrm{C}$.

\section{Cycloadduct 13a}

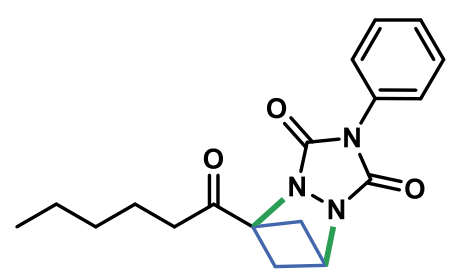

Prepared according to General procedure F on a $0.26 \mathrm{mmol}$ scale. Reaction of BCB 2 (40 mg, 0.26 mmol) with TAD 10a $(91 \mathrm{mg}, 0.52 \mathrm{mmol})$ in THF $(4.33 \mathrm{~mL})$ followed by purification by flash chromatography (silica, 1:50 v/v Et $\mathrm{t}_{2} \mathrm{O}: \mathrm{DCM}$ ) afforded the desired product 13a (40 $\mathrm{mg}, 46 \%$ ), as a colourless solid. Crystallisation of 13a from the slow evaporation of EtOAc afforded crystals which were subjected to single crystal $\mathrm{x}$-ray analysis. The associated data of this experiment, which includes a thermal ellipsoid plot, are disclosed in the Crystallographic Data section of this document.

$\mathbf{R}_{f}=0.73\left(1: 50 v / v \mathrm{Et}_{2} \mathrm{O}: \mathrm{DCM}\right)$.

${ }^{1} \mathbf{H}$ NMR (400 MHz, CDCl 3 ) $\delta$ 7.50-7.37 (m, 5H), 4.79 (app. t, $\left.J=1.8 \mathrm{~Hz}, 1 \mathrm{H}\right) 2.94$ (t, $J=7.3 \mathrm{~Hz}$, $2 \mathrm{H}), 2.57-2.49(\mathrm{~m}, 2 \mathrm{H}), 2.12-2.04(\mathrm{~m}, 2 \mathrm{H}), 1.73-1.64(\mathrm{~m}, 2 \mathrm{H}), 1.38-1.25(\mathrm{~m}, 4 \mathrm{H}), 0.90(\mathrm{t}, J=7.0$ $\mathrm{Hz}, 3 \mathrm{H})$

${ }^{13}$ C NMR (101 MHz, $\left.\mathbf{C D C l}_{3}\right) \delta 202.0,160.0,159.2,131.2,129.4,128.9,125.5,78.4,59.9,42.8$, $39.3,31.3,22.7,22.5,14.0$.

LRMS (ESI $\left.{ }^{+}\right): m / z$ (rel. int.) $677(100)[2 \mathrm{M}+\mathrm{Na}]^{+}$.

HRMS (ESI ${ }^{+}$): calc'd for $\mathrm{C}_{18} \mathrm{H}_{21} \mathrm{~N}_{3} \mathrm{NaO}_{3}[\mathrm{M}+\mathrm{Na}]^{+}:$350.14751, found 350.14734 .

IR: $\mathrm{V}_{\max }=2932,1714,1504,1398,1139,687 \mathrm{~cm}^{-1}$.

MP: $79-81{ }^{\circ} \mathrm{C}$.

\section{Cycloadduct 13b}<smiles>CCCCCC(=O)C12CC(C1)n1c(=O)n(-c3ccc(OC)cc3)c(=O)n12</smiles> 
Prepared according to General procedure F on a $0.26 \mathrm{mmol}$ scale. Reaction of BCB 2 ( $40 \mathrm{mg}, 0.26$ mmol) with TAD 10b $(107 \mathrm{mg}, 0.52 \mathrm{mmol})$ in THF $(4.30 \mathrm{~mL})$ followed by purification by flash chromatography (silica, 1:50 v/v $\mathrm{Et}_{2} \mathrm{O}: \mathrm{DCM}$ ) afforded the desired product 13b (45 $\mathrm{mg}, 50 \%$ ), as a colourless solid.

$\mathbf{R}_{f}=0.53\left(1: 50 v / v \mathrm{Et}_{2} \mathrm{O}: \mathrm{DCM}\right)$.

${ }^{1} \mathbf{H}$ NMR (400 MHz, $\left.\mathbf{C D C l}_{3}\right) \delta 7.36-7.31(\mathrm{~m}, 2 \mathrm{H}), 7.00-6.94(\mathrm{~m}, 2 \mathrm{H}), 4.77$ (app. t, $J=2.0 \mathrm{~Hz}$, $1 \mathrm{H}), 3.82(\mathrm{~s}, 3 \mathrm{H}), 2.93(\mathrm{t}, J=7.3 \mathrm{~Hz}, 2 \mathrm{H}), 2.52-2.51(\mathrm{~m}, 2 \mathrm{H}), 2.08-2.06(\mathrm{~m}, 2 \mathrm{H}), 1.73-1.66(\mathrm{~m}$, $2 \mathrm{H}), 1.36-1.31(\mathrm{~m}, 4 \mathrm{H}), 0.89$ (t, $J=6.9 \mathrm{~Hz}, 3 \mathrm{H})$.

${ }^{13}$ C NMR (101 MHz, $\left.\mathbf{C D C l}_{3}\right) \delta 202.1,160.0,159.8,159.6,127.0,123.8,114.7,78.4,59.9,55.7$, $42.8,39.3,31.3,22.7,22.6,14.0$.

LRMS (ESI $\left.{ }^{+}\right): m / z$ (rel. int.) $737(100)[2 \mathrm{M}+\mathrm{Na}]^{+}$.

HRMS (ESI ${ }^{+}$): calc'd for $\mathrm{C}_{19} \mathrm{H}_{23} \mathrm{~N}_{3} \mathrm{NaO}_{4}[\mathrm{M}+\mathrm{Na}]^{+}$: 380.1581; found 380.1574.

IR: $V_{\max }=2934,1725,1515,1402,1253,829 \mathrm{~cm}^{-1}$.

MP: $60-62{ }^{\circ} \mathrm{C}$.

\section{Cycloadduct 13c}

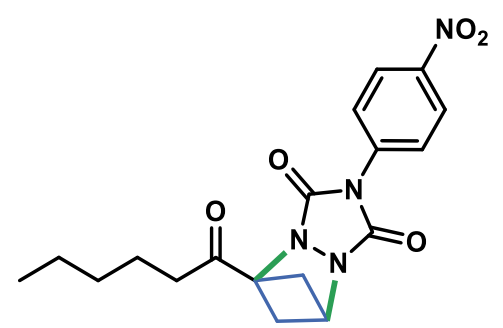

Prepared according to General procedure F on a 0.26 mmol scale. Reaction of BCB 2 ( $40 \mathrm{mg}, 0.26$ mmol) with TAD 10c $(114 \mathrm{mg}, 0.52 \mathrm{mmol})$ in THF $(4.30 \mathrm{~mL})$ followed by purification by flash chromatography (silica, 1:50 v/v $\left.\mathrm{Et}_{2} \mathrm{O}: \mathrm{DCM}\right)$ afforded the desired product 13c $(54 \mathrm{mg}, 58 \%)$, as a colourless solid. Crystallisation of $\mathbf{1 3 c}$ from the slow evaporation of EtOAc afforded crystals which were subjected to single crystal x-ray analysis. The associated data of this experiment, which includes a thermal ellipsoid plot, are disclosed in the Crystallographic Data section of this document.

$\mathbf{R}_{f}=0.67\left(1: 50 v / v \mathrm{Et}_{2} \mathrm{O}: \mathrm{DCM}\right)$.

${ }^{1} \mathbf{H}$ NMR (400 MHz, $\left.\mathbf{C D C l}_{3}\right) \delta 8.36-8.31(\mathrm{~m}, 2 \mathrm{H}), 7.88-7.83(\mathrm{~m}, 2 \mathrm{H}), 4.83$ (app. t, $J=2.0 \mathrm{~Hz}$, $1 \mathrm{H}), 2.93(\mathrm{t}, J=7.3 \mathrm{~Hz}, 2 \mathrm{H}), 2.61-2.53(\mathrm{~m}, 2 \mathrm{H}), 2.13-2.05(\mathrm{~m}, 2 \mathrm{H}), 1.74-1.65(\mathrm{~m}, 2 \mathrm{H}), 1.38-1.29$ (m, 4H), $0.91(\mathrm{t}, J=6.9 \mathrm{~Hz}, 3 \mathrm{H})$.

${ }^{13}$ C NMR (101 MHz, $\left.\mathbf{C D C l}_{3}\right) \delta 201.5,158.5,158.0,147.0,137.0,125.0,124.7,78.7,60.2,43.2$, $39.3,31.3,22.7,22.6,14.1$. 
LRMS (ESI $\left.{ }^{+}\right): m / z$ (rel. int.) 767 (100) [2M+Na $]^{+}$.

HRMS (ESI ${ }^{+}$): calc'd for $\mathrm{C}_{18} \mathrm{H}_{20} \mathrm{~N}_{4} \mathrm{NaO}_{5}[\mathrm{M}+\mathrm{Na}]^{+}: 350.14751$, found 350.14734 .

IR: $\mathrm{V}_{\max }=2957,1725,1599,1524,1500,1390,1345,1311,1111,908,727 \mathrm{~cm}^{-1}$.

MP: $106-108^{\circ} \mathrm{C}$.

\section{Cycloadduct 14a}<smiles>O=C(c1ccccc1)C12CC(C1)n1c(=O)n(-c3ccccc3)c(=O)n12</smiles>

Prepared according to General procedure F on a $0.32 \mathrm{mmol}$ scale. Reaction of BCB 3 (51 $\mathrm{mg}, 0.32$ mmol) with TAD 10a $(112 \mathrm{mg}, 0.64 \mathrm{mmol})$ in THF $(5.30 \mathrm{~mL})$ followed by purification by flash chromatography (silica, 1:50 v/v $\mathrm{Et}_{2} \mathrm{O}: \mathrm{DCM}$ ), afforded the desired product 14a (56 $\mathrm{mg}, 53 \%$ ) as a colourless solid. Crystallisation of 14a from the slow evaporation of EtOAc afforded crystals which were subjected to single crystal $\mathrm{x}$-ray analysis. The associated data of this experiment, which includes a thermal ellipsoid plot, are disclosed in the Crystallographic Data section of this document.

$\mathbf{R}_{\boldsymbol{f}}=0.58\left(1: 50 v / v \mathrm{Et}_{2} \mathrm{O}: \mathrm{DCM}\right)$.

${ }^{1}$ H NMR (400 MHz, CDCl $\left.)_{3}\right) \delta 8.24-8.19(\mathrm{~m}, 2 \mathrm{H}), 7.65-7.59(\mathrm{~m}, 1 \mathrm{H}), 7.54-7.48(\mathrm{~m}, 2 \mathrm{H}), 7.47-7.38$ (m, 4H), 7.38-7.34 (m, 1H), 4.88 (app. t, $J=1.9 \mathrm{~Hz}, 1 \mathrm{H}), 2.76-2.68$ (m, 2H), 2.37-2.29 (m, 2H).

${ }^{13}$ C NMR (151 MHz, CDCl $) \delta$ 190.7, 159.4, 159.0, 134.7, 134.3, 131.3, 129.5, 129.3, 128.9, 128.8, $125.3,77.7,60.0,44.0$.

LRMS (ESI ${ }^{+}$): $m / z$ (rel. int.) $689(100)[2 \mathrm{M}+\mathrm{Na}]^{+}$.

HRMS (ESI'): calc'd for $\mathrm{C}_{19} \mathrm{H}_{15} \mathrm{~N}_{3} \mathrm{O}_{3} \mathrm{Na}^{+}[\mathrm{M}+\mathrm{Na}]^{+}$356.1011; found 356.1104.

IR: $\mathrm{V}_{\max }=2926,1719,1676,1400,1136,715 \mathrm{~cm}^{-1}$.

MP: $158-160^{\circ} \mathrm{C}$. 
<smiles></smiles>

Prepared according to General procedure F on a $0.32 \mathrm{mmol}$ scale. Reaction of BCB 3 (51 $\mathrm{mg}, 0.32$ mmol) with TAD 10b $(131 \mathrm{mg}, 0.64 \mathrm{mmol})$ in THF $(5.30 \mathrm{~mL})$ followed by purification by flash chromatography (silica, 1:50 v/v $\mathrm{Et}_{2} \mathrm{O}: \mathrm{DCM}$ ), afforded the desired product $\mathbf{1 4 b}$ (57 $\mathrm{mg}, 50 \%$ ), as a colourless solid. Crystallisation of $\mathbf{1 4 b}$ from the slow evaporation of EtOAc afforded crystals which were subjected to single crystal $\mathrm{x}$-ray analysis. The associated data of this experiment, which includes a thermal ellipsoid plot, are disclosed in the Crystallographic Data section of this document.

$\mathbf{R}_{f}=0.50\left(1: 50 v / v \mathrm{Et}_{2} \mathrm{O}: \mathrm{DCM}\right)$.

${ }^{1}$ H NMR (400 MHz, $\left.\mathbf{C D C l}_{3}\right) \delta 8.25-8.17(\mathrm{~m}, 2 \mathrm{H}), 7.65-7.59(\mathrm{~m}, 1 \mathrm{H}), 7.55-7.47(\mathrm{~m}, 2 \mathrm{H}), 7.36$ $-7.31(\mathrm{~m}, 2 \mathrm{H}), 6.94-6.92(\mathrm{~m}, 2 \mathrm{H}), 4.86$ (app. t, $J=1.7 \mathrm{~Hz}, 1 \mathrm{H}), 3.80(\mathrm{~s}, 3 \mathrm{H}), 2.74-2.67$ (m, 2H), $2.36-2.27(\mathrm{~m}, 2 \mathrm{H})$.

${ }^{13}$ C NMR (101 MHz, $\left.\mathbf{C D C l}_{3}\right) \delta$ 190.7, 159.7, 159.7, 159.3, 134.6, 134.2, 129.5, 128.9, 126.9, 123.9, 114.6, 77.6, 59.9, 55.6, 43.9.

LRMS (ESI $\left.{ }^{+}\right): m / z$ (rel. int.) $749(100)[2 \mathrm{M}+\mathrm{Na}]^{+}$.

HRMS (ESI ${ }^{+}$): calc'd for $\mathrm{C}_{20} \mathrm{H}_{17} \mathrm{~N}_{3} \mathrm{NaO}_{4}[\mathrm{M}+\mathrm{Na}]^{+}$: 386.1117 , found 386.1117 .

IR: $V_{\max }=2937,1718,1669,1515,1402,1255,1137,825,703 \mathrm{~cm}^{-1}$.

MP: $170-172{ }^{\circ} \mathrm{C}$.

\section{Cycloadduct 14c}<smiles>O=C(c1ccccc1)C12CCC(C1)n1c(=O)n(-c3ccc([N+](=O)[O-])cc3)c(=O)n12</smiles> 
Prepared according to General procedure F on a $0.32 \mathrm{mmol}$ scale. Reaction of BCB 3 (51 mg, 0.32 mmol) with TAD $10 \mathrm{c}(141 \mathrm{mg}, 0.64 \mathrm{mmol})$ in THF $(5.30 \mathrm{~mL})$ followed by purification by flash column chromatography (silica, 1:50 v/v Et $\left.{ }_{2} \mathrm{O}: \mathrm{DCM}\right)$, afforded 14c $(75 \mathrm{mg}, 63 \%)$ as a colourless solid. Crystallisation of 14c from the slow evaporation of EtOAc afforded crystals which were subjected to single crystal $\mathrm{x}$-ray analysis. The associated data of this experiment, which includes a thermal ellipsoid plot, are disclosed in the Crystallographic Data section of this document.

$\mathbf{R}_{\boldsymbol{f}}=0.7\left(1: 50 v / v \mathrm{Et}_{2} \mathrm{O}: \mathrm{DCM}\right)$.

${ }^{1}$ H NMR (400 MHz, $\left.\mathbf{C D C l}_{3}\right) \delta 8.32-8.27(\mathrm{~m}, 2 \mathrm{H}), 8.23-8.18(\mathrm{~m}, 2 \mathrm{H}), 7.87-7.82(\mathrm{~m}, 2 \mathrm{H}), 7.67$ $-7.62(\mathrm{~m}, 1 \mathrm{H}), 7.56-7.50(\mathrm{~m}, 2 \mathrm{H}), 4.92(\mathrm{app} \mathrm{t}, J=1.8 \mathrm{~Hz}, 1 \mathrm{H}), 2.80-2.72(\mathrm{~m}, 2 \mathrm{H}), 2.38-2.30$ $(\mathrm{m}, 2 \mathrm{H})$.

${ }^{13}$ C NMR (151 MHz, $\left.\mathbf{C D C l}_{3}\right) \delta 190.2,158.1,157.9,146.9,137.1,134.5,134.4,129.5,129.1,124.8$, $124.6,77.9,60.2,44.3$.

LRMS (ESI $\left.{ }^{+}\right): m / z$ (rel. int.) $779(100)[2 \mathrm{M}+\mathrm{Na}]^{+}$.

HRMS (EI): calc'd for $\mathrm{C}_{19} \mathrm{H}_{14} \mathrm{O}_{5}[\mathrm{M}]^{+}:$: 378.0962, found 378.0964.

IR: $\mathrm{V}_{\max }=3071,1722,1665,1596,1517,1386,1342,1106,850,694 \mathrm{~cm}^{-1}$.

MP: $188-190^{\circ} \mathrm{C}$.

Preparation of Boc-protected urazole $\mathbf{1 8}$
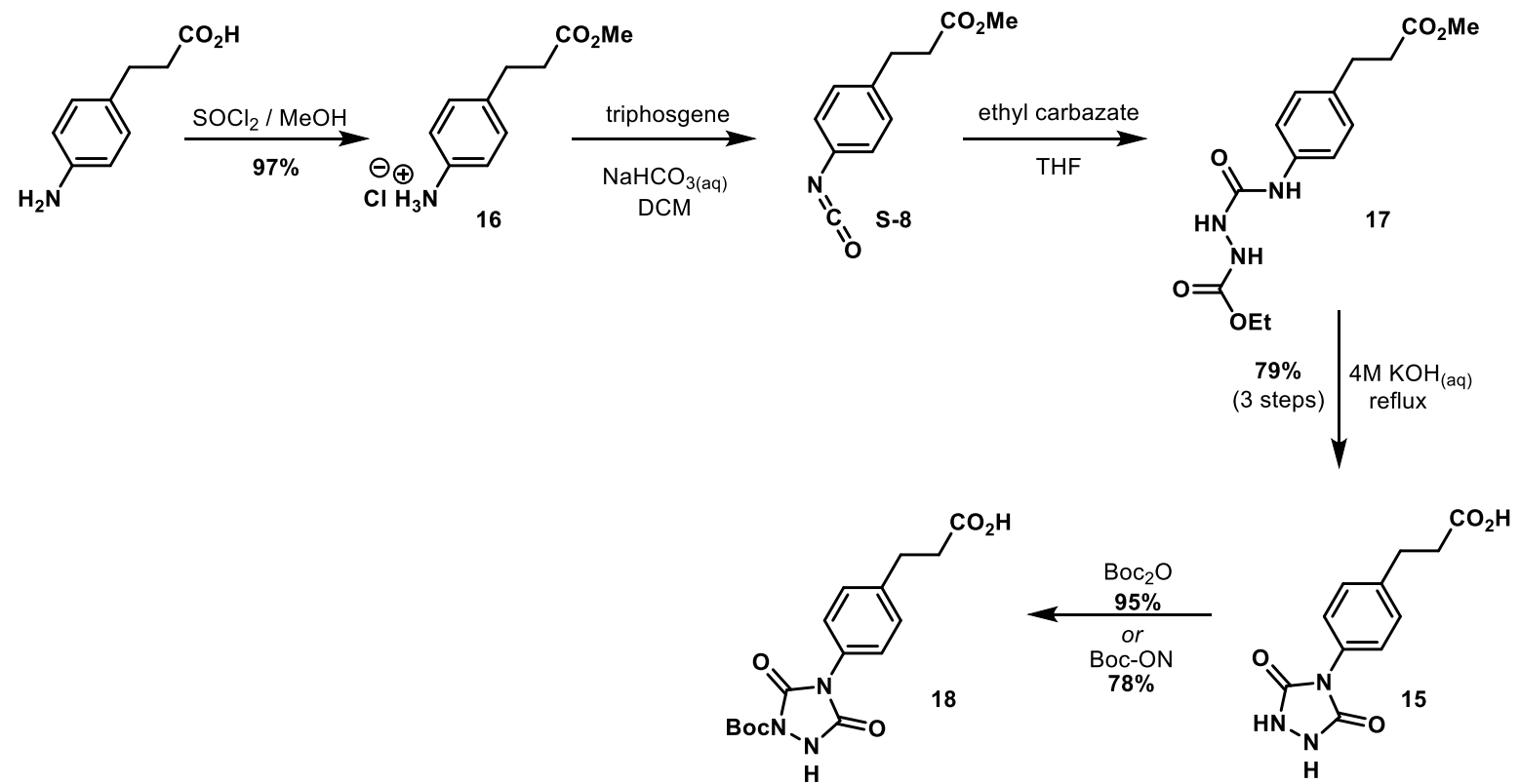

Methyl 3-(4-aminophenyl)propanoate hydrochloride $\mathbf{1 6}$

Magnetically stirred methanol $(45 \mathrm{~mL})$, maintained at $0{ }^{\circ} \mathrm{C}$ (ice-bath) under a nitrogen atmosphere, was treated dropwise with thionyl chloride $(10 \mathrm{~mL})$. The resulting solution was stirred for $0.1 \mathrm{~h}$ and then treated with 3-(4-aminophenyl)propanoic acid $(5.34 \mathrm{~g}, 32.3 \mathrm{mmol})$ and the ensuing mixture 
heated under reflux for $2 \mathrm{~h}$ before being cooled then concentrated to ca. $20 \mathrm{~mL}$ under a gentle stream of nitrogen. The mixture was then poured into ether $(100 \mathrm{~mL})$, stirred vigorously for $0.1 \mathrm{~h}$, and the precipitate collected by vacuum filtration. The retained solids were washed with ether $(30 \mathrm{~mL})$ to provide methyl 3-(4-aminophenyl)propanoate hydrochloride (16) (6.77 g 97\%) as a cream-coloured powder and used without further purification.

${ }^{1}$ H NMR (400 MHz, DMSO-d $\left.\mathbf{d}_{\mathbf{6}}\right) \delta 10.26$ (br s, 3H), $7.35-7.31$ (m, 2H), $7.30-7.26(\mathrm{~m}, 2 \mathrm{H}), 3.57$ (s, 3H), 2.86 (t, $J=7.5 \mathrm{~Hz}, 2 \mathrm{H}), 2.64$ (t, $J=7.5 \mathrm{~Hz}, 2 \mathrm{H})$.

${ }^{13}$ C NMR (101 MHz, DMSO-d $) \delta$ 172.5, 140.3, 130.1, 129.5, 123.0, 51.3, 34.6, 29.6.

LRMS (ESI $\left.{ }^{+}\right): m / z$ (rel. int.) $180(100)[\mathrm{M}+\mathrm{H}]^{+}$.

HRMS (ESI $\left.{ }^{+}\right)$: calc'd for $\mathrm{C}_{10} \mathrm{H}_{14} \mathrm{NO}_{2}[\mathrm{M}+\mathrm{H}]^{+}: 180.1019$, found: 180.1015 .

IR: $\mathrm{V}_{\max }=2871,2587,1997,1732,1507,1432,1166,825 \mathrm{~cm}^{-1}$.

Isocyanate $\mathbf{S - 8 , ~ e t h y l ~ c a r b a z a t e ~ a d d u c t ~} \mathbf{1 7}$ and urazole $\mathbf{1 5}$

A vigorously stirring ice-cold mixture of DCM $(100 \mathrm{~mL})$ and aqueous $\mathrm{NaHCO}_{3}(100 \mathrm{~mL}, 1 \mathrm{M})$ was treated portion-wise with methyl 3-(4-aminophenyl)propanoate hydrochloride (16) (3.05 g, $14.1 \mathrm{mmol})$. After $5 \mathrm{~min}$, triphosgene $(1.69 \mathrm{~g}, 5.70 \mathrm{mmol})$ was added portion-wise over two minutes and stirring maintained for $0.5 \mathrm{~h}$. The cold bath was removed and after $0.5 \mathrm{~h}$ the mixture was partitioned in a separatory funnel. The organic layer was collected, washed with water $(20 \mathrm{~mL})$, dried $\left(\mathrm{Na}_{2} \mathrm{SO}_{4}\right)$ and concentrated under reduced pressure to afford crude methyl 3-(4isocyanatophenyl)propanoate (S-8) as a tan-coloured oil which was used without purification. A magnetically stirred solution of the so-formed, crude isocyanate in THF $(30 \mathrm{~mL})$, maintained in an ice-bath was treated portion-wise with ethyl carbazate (S-1) $(1.48 \mathrm{~g}, 14.2 \mathrm{mmol})$. A white precipitate immediately formed and after $1 \mathrm{~h}$ the cold-bath was removed and stirring maintained at $\mathrm{rt}$ for $18 \mathrm{~h}$. The mixture was poured into ice-cold water $(100 \mathrm{~mL})$ and the mixture stirred vigorously for $5 \mathrm{~min}$ before collecting the solids by vacuum filtration. The filter-cake was washed with ice-cold water $(50 \mathrm{~mL})$ to afford $\mathbf{1 7}$ as a damp, white powder which was used without further purification. A portion of the above collected powder $(\sim 50 \mathrm{mg})$ was dried further under reduced pressure $(0.3 \mathrm{mmHg}, 18 \mathrm{~h})$ for characterisation purposes. The remaining bulk of the crude material described directly above was suspended in aqueous potassium hydroxide $(50 \mathrm{~mL}, 4 \mathrm{M})$ and heated under reflux for $3 \mathrm{~h}$. The resulting clear solution was cooled in an ice-bath to $\sim 5{ }^{\circ} \mathrm{C}$ then acidified with aqueous $\mathrm{HCl}(5 \mathrm{M})$ to $\mathrm{pH} \sim 1$. The precipitate was collected by vacuum filtration, washed with cold water $(30 \mathrm{~mL})$ then dried under reduced pressure $(0.3 \mathrm{mmHg}, 36 \mathrm{~h})$ to afford $\mathbf{1 5}(2.78 \mathrm{~g}, 79 \%$ over $3 \mathrm{steps})$ as a cream powder.

Data for methyl 3-(4-isocyanatophenyl)propanoate (S-8)

${ }^{1}$ H NMR (400 MHz, CDCl $) \delta 7.17-7.12$ (m, 2H), $7.03-6.99$ (m, 2H), 3.66 (s, 3H), 2.92 (app. t, $J=7.7 \mathrm{~Hz}, 2 \mathrm{H}$ ), 2.61 (app. t, $J=7.7 \mathrm{~Hz}, 2 \mathrm{H}$ ).

${ }^{13}$ C NMR (101 MHz, $\left.\mathbf{C D C l}_{3}\right) \delta 173.2,138.3,131.7,129.6,124.9,124.8,51.8,35.7,30.5$. 
Data for ethyl carbazate adduct $\mathbf{1 7}$

${ }^{1}$ H NMR (400 MHz, DMSO-d $\left.\boldsymbol{d}_{6}\right) \delta 8.89$ (br s, 1H), 8.62 (s, 1H), 7.94 (br s, 1H), $7.39-7.31$ (m, 2H), $7.12-7.06$ (m, 2H), 4.05 (q, $J=7.1 \mathrm{~Hz}, 2 \mathrm{H}), 3.57$ (s, 3H), 2.77 (app. t, $J=7.6 \mathrm{~Hz}, 2 \mathrm{H}$ ), 2.58 (app. t, $J=7.6 \mathrm{~Hz}, 2 \mathrm{H}), 1.19$ (t, $J=6.8 \mathrm{~Hz}, 3 \mathrm{H})$.

${ }^{13}$ C NMR (101 MHz, DMSO-d $\left.\mathbf{6}\right) \delta$ 172.7, 157.0, 155.6, 137.8, 133.8, 128.3, 118.6, 60.5, 51.2, 35.1, 29.6, 14.6 .

LRMS (ESI $\left.{ }^{+}\right): m / z$ (rel. int.) $332(100)[\mathrm{M}+\mathrm{Na}]^{+}$.

HRMS (ESI ${ }^{+}$): calc'd for $\mathrm{C}_{14} \mathrm{H}_{19} \mathrm{~N}_{3} \mathrm{NaO}_{5}[\mathrm{M}+\mathrm{Na}]^{+}: 332.1217$, found: 332.1222 .

IR: $\mathrm{V}_{\max }=3277,1740,1553,1235,845 \mathrm{~cm}^{-1}$.

MP: $196-200{ }^{\circ} \mathrm{C}$.

\section{Data for urazole 15}

${ }^{1}$ H NMR (400 MHz, DMSO-d d $_{\text {) }} \delta 12.15$ (s, 1H), 10.41 (s, 2H), 7.34 - 7.32 (m, 4H), 2.86 (app. t, $J$ $=7.6 \mathrm{~Hz}, 2 \mathrm{H}$ ), 2.56 (app. t, $J=7.6 \mathrm{~Hz}, 2 \mathrm{H}$ ).

${ }^{13}$ C NMR (101 MHz, DMSO-d $)$ ) $\delta$ 173.7, 153.5, 140.5, 129.8, 128.6, 126.0, 35.1, 30.0.

LRMS (ESI $\left.{ }^{+}\right): m / z$ (rel. int.) $272(100)[\mathrm{M}+\mathrm{Na}]^{+}$.

HRMS (ESI ${ }^{+}$): calc'd for $\mathrm{C}_{11} \mathrm{H}_{11} \mathrm{~N}_{3} \mathrm{NaO}_{4}[\mathrm{M}+\mathrm{Na}]^{+}: 272.0642$, found: 272.0642 .

IR: $\mathrm{V}_{\max }=1778,1674 \mathrm{~cm}^{-1}$.

MP: $227-231^{\circ} \mathrm{C}$.

Boc-protected urazole 18

18 From BOC-ON (2-(Boc-oxyimino)-2-phenylacetonitrile)

A magnetically stirred suspension of $15(650 \mathrm{mg}, 2.61 \mathrm{mmol})$ in a mixture of acetonitrile $(15 \mathrm{~mL})$ and THF $(3 \mathrm{~mL})$ was treated sequentially with triethylamine $(1.09 \mathrm{~mL}, 7.83 \mathrm{mmol})$ and then BOC-ON (2-(Boc-oxyimino)-2-phenylacetonitrile) ( $834 \mathrm{mg}, 3.39 \mathrm{mmol}$ ). The mixture was stirred vigorously for $18 \mathrm{~h}$ and then concentrated under reduced pressure which afforded a viscous oil. Subjection of this material to purification by flash chromatography (silica, 45:6:0.2 v/v/v DCM/MeOH/AcOH) afforded Boc-adduct 18 (706 mg, 78\%).

$\mathbf{R}_{\boldsymbol{f}}=0.4(45: 6: 0.2 v / v / v \mathrm{DCM} / \mathrm{MeOH} / \mathrm{AcOH})$

${ }^{1}$ H NMR (400 MHz, DMSO-d 6 ) $\delta 12.13$ (br s, 1H), 11.45 (br s, 1H), 7.37 - 7.30 (m, 4H), 2.86 (app. t, $J=7.6 \mathrm{~Hz}, 2 \mathrm{H}), 2.57$ (app. t, $J=7.6 \mathrm{~Hz}, 2 \mathrm{H}), 1.51$ (s, 9H). 
${ }^{13}$ C NMR (101 MHz, DMSO-d (1) $^{\delta}$ 173.7, 150.5, 146.8, 145.8, 141.2, 129.1, 128.7, 126.8, 84.4, 35.0, 30.0, 27.6.

LRMS (ESI $\left.{ }^{+}\right): m / z$ (rel. int.) $372(100)[\mathrm{M}+\mathrm{Na}]^{+}$.

HRMS (ESI ${ }^{+}$): calc'd for $\mathrm{C}_{16} \mathrm{H}_{19} \mathrm{~N}_{3} \mathrm{NaO}_{6}[\mathrm{M}+\mathrm{Na}]^{+}: 372.1166$, found: 372.1172 .

IR: $\mathrm{V}_{\max }=1825,1745,1719,1286,1131 \mathrm{~cm}^{-1}$.

MP: $225-227^{\circ} \mathrm{C}$.

\section{From di-tert-butyl dicarbonate}

A magnetically stirred suspension of $15(1.12 \mathrm{~g}, 4.5 \mathrm{mmol})$ in water $(5 \mathrm{~mL})$ and dioxane $(5 \mathrm{~mL})$ was treated with sodium hydroxide $(358 \mathrm{mg}, 8.95 \mathrm{mmol})$ in one portion. After 1 minute the clear solution was treated with di-tert-butyl dicarbonate $(1.27 \mathrm{~g}, 5.82 \mathrm{mmol})$ and the mixture stirred for $24 \mathrm{~h}$. Water $(25 \mathrm{~mL})$ was added and the mixture washed with ether $(2 \times 10 \mathrm{~mL})$. The retained aqueous layer was then cooled in an ice-bath and acidified to $\mathrm{pH} \sim 1-2$ with potassium hydrogen sulfate $(0.5 \mathrm{M})$ and then extracted with DCM $(3 \times 15 \mathrm{~mL})$. The combined organic layers were washed with brine $(15 \mathrm{~mL})$ then concentrated under reduced pressure, to afford 18 as a white powder $(1.49 \mathrm{~g}, 95 \%)$ contaminated with ca. $4 \%$ dioxane (from integration of signals in the ${ }^{1} \mathrm{H}$ NMR), which was used without further purification. Spectral data matched those reported above.

Preparation of Boc-protected urazole $\mathbf{2 3}$
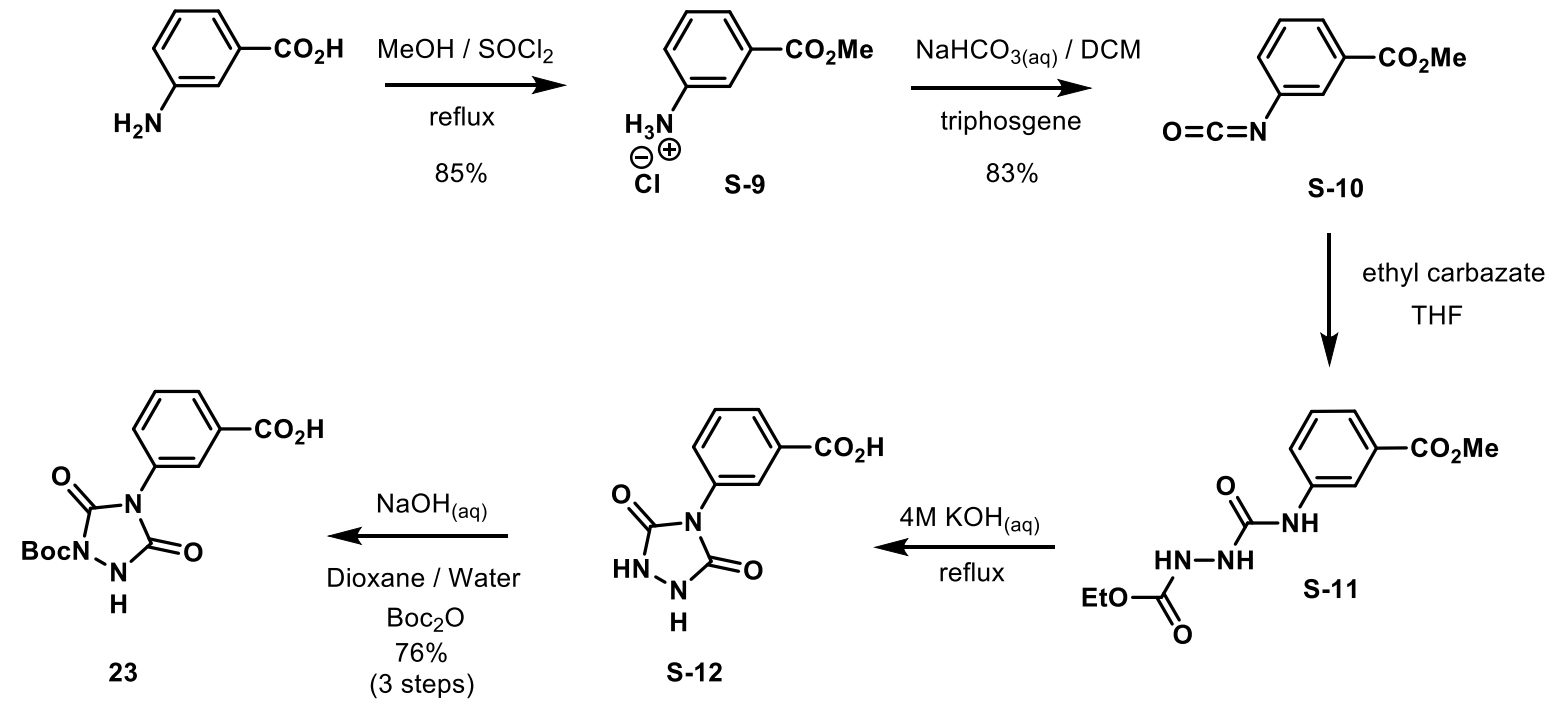


\section{Methyl 3-aminobenzoate hydrochloride $\mathbf{S - 9}$}

Magnetically stirred methanol $(50 \mathrm{~mL})$, maintained at $0{ }^{\circ} \mathrm{C}$ (ice-bath) under a nitrogen atmosphere, was treated dropwise with thionyl chloride $(10 \mathrm{~mL})$. The resulting solution was stirred for $0.1 \mathrm{~h}$ and then treated with 3-aminobenzoic acid $(3.27 \mathrm{~g}, 23.9 \mathrm{mmol})$ and the ensuing mixture heated under reflux for $3 \mathrm{~h}$ before being cooled then concentrated to ca. $20 \mathrm{~mL}$ under a gentle stream of nitrogen. The mixture was then poured into ether $(100 \mathrm{~mL})$, stirred vigorously for $0.1 \mathrm{~h}$, then the precipitate collected by vacuum filtration. The retained solids were washed with ether $(30 \mathrm{~mL})$ to provide methyl 3-aminobenzoate hydrochloride (S-9) $(3.81 \mathrm{~g} 85 \%)$ as a cream-coloured powder and used without further purification.

${ }^{1}$ H NMR (400 MHz, DMSO-d $\left.\mathbf{d}_{\mathbf{6}}\right) 3$ NHs not observed $\delta 7.83-7.78(\mathrm{~m}, 2 \mathrm{H}), 7.59-7.49(\mathrm{~m}, 2 \mathrm{H}), 3.87$ $(\mathrm{s}, 3 \mathrm{H})$.

${ }^{13}$ C NMR (101 MHz, DMSO-d $\left.\mathbf{d}\right) 1$ Ar-C overlapping $\delta$ 165.5, 135.8, 130.8, 130.2, 126.3, 122.0, 52.4 .

LRMS (ESI $\left.{ }^{+}\right): m / z$ (rel. int.) $152(100)[\mathrm{M}+\mathrm{H}]^{+}$.

HRMS $\left(\mathrm{ESI}^{+}\right)$: calc'd for $\mathrm{C}_{8} \mathrm{H}_{10} \mathrm{NO}_{2}[\mathrm{M}+\mathrm{H}]^{+}:$152.0706, found: 152.0709 .

\section{Boc-Protected urazole $\mathbf{2 3}$}

A vigorously stirring mixture of DCM $(70 \mathrm{~mL})$ and aqueous $\mathrm{NaHCO}_{3}(100 \mathrm{~mL}, 1 \mathrm{M})$, maintained in an ice-bath, was treated portion-wise with methyl methyl 3-aminobenzoate hydrochloride (S-9) (1.90 $\mathrm{g}, 10.1 \mathrm{mmol})$. After $5 \mathrm{~min}$ triphosgene $(1.20 \mathrm{~g}, 4.00 \mathrm{mmol}$, CAUTION!) was added portion-wise over two minutes and stirring maintained for $0.5 \mathrm{~h}$. The cold bath was removed and after $0.5 \mathrm{~h}$ the mixture was partitioned in separatory funnel. The organic layer was collected, washed with water (20 $\mathrm{mL})$, dried $\left(\mathrm{Na}_{2} \mathrm{SO}_{4}\right)$, and concentrated under reduced pressure to afford methyl 3-isocyanatobenzoate (S-10) $(1.48 \mathrm{~g}, 83 \%)$ as a tan-coloured oil, which was used immediately and without further purification. A magnetically stirred solution of the so-formed, crude isocyanate $\mathbf{S - 1 0}$ (1.38 g, 8.34 mmol) in THF (30 mL), maintained in an ice-bath, was treated portion-wise with ethyl carbazate (S1) $(1.04 \mathrm{~g}, 10.0 \mathrm{mmol})$. A white precipitate immediately formed and after $1 \mathrm{~h}$ the cold-bath was removed and stirring maintained at $\mathrm{rt}$ for $18 \mathrm{~h}$. The mixture was poured into ice-cold water $(100 \mathrm{~mL})$ and the mixture stirred vigorously for $5 \mathrm{~min}$ before collecting the solids by vacuum filtration. The filter-cake was washed with ice-cold water $(50 \mathrm{~mL})$ to afford $\mathbf{S - 1 1}$ as a damp, white powder and used without further purification. A portion of this powder $(\sim 50 \mathrm{mg})$ was dried further under reduced pressure $(0.3 \mathrm{mmHg}, 18 \mathrm{~h})$ for characterisation purposes. The remaining bulk of the crude material was suspended in aqueous potassium hydroxide $(50 \mathrm{~mL}, 4 \mathrm{M})$ and heated under reflux for $3 \mathrm{~h}$. The resulting clear solution was cooled in an ice-bath to $\sim 5^{\circ} \mathrm{C}$ then acidified with aqueous $\mathrm{HCl}(5 \mathrm{M})$ to $\mathrm{pH} \sim 1$ to afford (S-12) as a white precipitate which was collected by vacuum filtration and washed with cold water $(30 \mathrm{~mL})$. A portion of this powder $(\sim 50 \mathrm{mg})$ was dried further under reduced pressure $(0.3 \mathrm{mmHg}, 18 \mathrm{~h})$ for characterisation purposes. The remaining bulk of the crude (S-12) was suspended in a mixture of water $(15 \mathrm{~mL})$, dioxane $(15 \mathrm{~mL})$ and sodium hydroxide $(1.00 \mathrm{~g}, 25.0$ mmol). Di-tert-butyl dicarbonate $(2.36 \mathrm{~g}, 10.8 \mathrm{mmol})$ was added and the mixture stirred for $72 \mathrm{~h}$. Water $(25 \mathrm{~mL})$ was added and the mixture washed with ether $(2 \times 20 \mathrm{~mL})$. The aqueous layer was cooled in an ice-bath then acidified to $\mathrm{pH} \sim 1$ with potassium hydrogen sulfate $(0.5 \mathrm{M})$ and then 
extracted with DCM $(3 \times 15 \mathrm{~mL})$. The combined organic layers were washed with brine $(15 \mathrm{~mL})$ then concentrated under reduced pressure, to afford $\mathbf{2 3}$ as a white powder (2.03 g, 76\% from isocyanate S-10).

Data for methyl 3-isocyanatobenzoate S-10

${ }^{1} \mathbf{H}$ NMR (400 MHz, $\left.\mathbf{C D C l}_{3}\right) \delta 7.89-7.84(\mathrm{~m}, 1 \mathrm{H}), 7.78-7.76$ (m, 1H), 7.40 (app. t, $J=7.9 \mathrm{~Hz}$, $1 \mathrm{H}), 7.29(\mathrm{~m}, 1 \mathrm{H}), 3.93(\mathrm{~s}, 3 \mathrm{H})$.

${ }^{13} \mathbf{C}$ NMR (101 MHz, $\left.\mathbf{C D C l}_{3}\right)$ NC彑 O obscured or not observed $\delta 166.1,134.0,131.9,129.8,129.1$, 127.0, 126.0, 52.6.

Data for ethyl carbazate adduct S-11

${ }^{1}$ H NMR (400 MHz, DMSO-d $\left.\boldsymbol{d}_{\mathbf{6}}\right) \boldsymbol{\delta} 9.03$ (br s, 1H), 8.95 (br s, 1H), $8.19-8.16$ (m, 1H), 8.13 (br s, 1H), 7.72 (br s, 1H), 7.54 (dt, $J=7.7,1.1 \mathrm{~Hz}, 1 \mathrm{H}), 7.39$ (app. t, $J=7.9 \mathrm{~Hz}, 1 \mathrm{H}), 4.06$ (q, $J=7.0 \mathrm{~Hz}$, $2 \mathrm{H}), 3.84(\mathrm{~s}, 3 \mathrm{H}), 1.20(\mathrm{t}, J=7.0 \mathrm{~Hz}, 3 \mathrm{H})$.

${ }^{13}$ C NMR (101 MHz, DMSO-d $\mathbf{6}$ ) $\delta$ 166.3, 156.9, 155.7 (br), 140.2, 130.0, 129.0, 123.1 (br), 122.5, 119.1 (br), 60.6, 52.1, 14.6.

LRMS (ESI-): $m / z$ (rel. int.) $280(100)[\mathrm{M}-\mathrm{H}]^{-}$.

HRMS (ESI-): calc'd for $\mathrm{C}_{12} \mathrm{H}_{14} \mathrm{~N}_{3} \mathrm{O}_{5}[\mathrm{M}-\mathrm{H}]^{-}: 280.0939$, found: 280.0943 .

IR: $\mathrm{V}_{\max }=3322,1718,1681,1614,1567,1255 \mathrm{~cm}^{-1}$.

Data for 1,2,4-triazolidine-3,5-dione derivative $\mathbf{S - 1 2}$

${ }^{1}$ H NMR (400 MHz, DMSO-d $\left.\boldsymbol{d}_{6}\right) \delta 13.18$ (br s, OH), 10.59 (s, (NH) $), 8.05$ (app. t, $J=1.7 \mathrm{~Hz}, 1 \mathrm{H}$ ), 7.94 (ddd, $J=7.8,1.2 \mathrm{~Hz}, 1 \mathrm{H}$ ), 7.75 (ddd, $J=8.0,2.2,1.2 \mathrm{~Hz}, 1 \mathrm{H}$ ), 7.61 (app. t, $J=7.8 \mathrm{~Hz}, 1 \mathrm{H}$ ).

${ }^{13}$ C NMR (101 MHz, DMSO-d $) \delta$ 166.6, 153.0, 132.3, 131.5, 130.0, 129.2, 128.2, 126.4 .

LRMS (ESI $\left.{ }^{-}\right): m / z$ (rel. int.) $220(100)[\mathrm{M}-\mathrm{H}]^{-}$.

HRMS (ESI-): calc'd for $\mathrm{C}_{9} \mathrm{H}_{6} \mathrm{~N}_{3} \mathrm{O}_{4}[\mathrm{M}-\mathrm{H}]^{-}:$220.0364, found: 220.0362

IR: $\mathrm{V}_{\max }=3244,1694,1668,1460,1259, \mathrm{~cm}^{-1}$.

Data for Boc-protected 1,2,4-triazolidine-3,5-dione derivative $\mathbf{2 3}$

${ }^{1}$ H NMR (400 MHz, DMSO-d 6 ) $\delta 13.19$ (br s, 1H), 11.66 (br s, 1H), 8.06 - 8.04 (m, 1H), 7.98 (app. dt, $J=7.7,1.4 \mathrm{~Hz}, 1 \mathrm{H}), 7.72$ (ddd, $J=7.9,2.1,1.2 \mathrm{~Hz}, 1 \mathrm{H}$ ), 7.63 (app. t, $J=7.9 \mathrm{~Hz}, 1 \mathrm{H}$ ), 1.52 (s, $9 \mathrm{H})$.

${ }^{13}$ C NMR (101 MHz, DMSO-d $\left.\boldsymbol{d}_{\mathbf{6}}\right) \delta$ 166.5, 150.1, 146.5, 145.7, 131.6, 131.5, 131.0, 129.2, 129.0, $127.5,84.5,27.6$.

LRMS (ESI-): $m / z$ (rel. int.) $320(100)[\mathrm{M}-\mathrm{H}]^{-}$.

HRMS (ESI-): calc'd for $\mathrm{C}_{14} \mathrm{H}_{14} \mathrm{~N}_{3} \mathrm{O}_{6}[\mathrm{M}-\mathrm{H}]^{-}: 320.0888$, found: 320.0886 .

IR: $\mathrm{V}_{\max }=2981,1735,1720,1700,1303,1133 \mathrm{~cm}^{-1}$. 
TAD cycloadduct $\mathbf{2 8}$
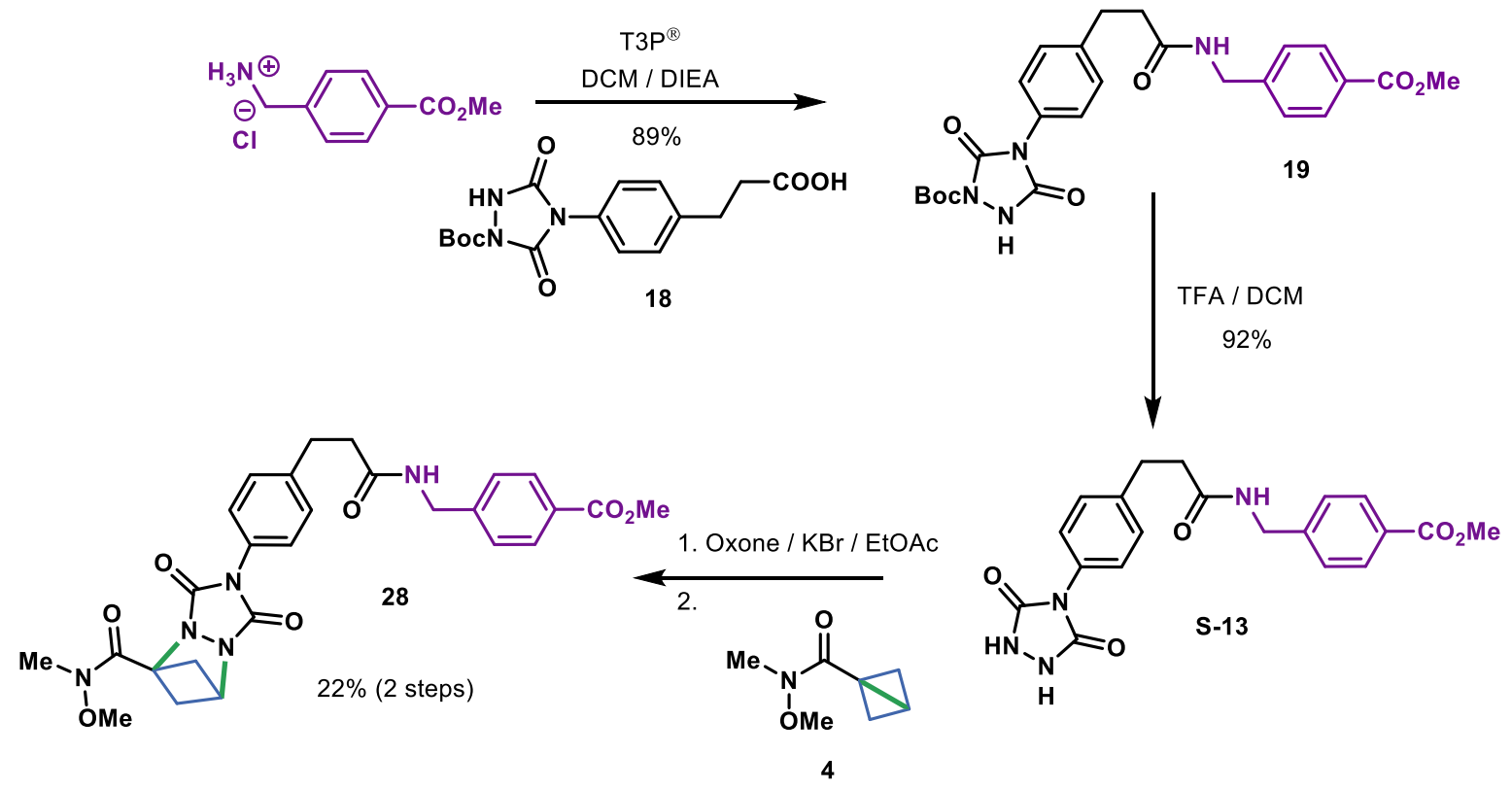

\section{Protected urazole adduct 19}

A magnetically stirred suspension of $18(208 \mathrm{mg}, 0.60 \mathrm{mmol})$ in $\mathrm{DCM}(5 \mathrm{~mL})$ maintained at $0{ }^{\circ} \mathrm{C}$ (ice-bath) was treated sequentially with DIEA $(628 \mu \mathrm{L}, 3.60 \mathrm{mmol})$, then $\mathrm{T}^{\mathrm{P}} \mathrm{P}^{\circledR}(535 \mu \mathrm{L}$ of a $50 \%$ $\mathrm{w} / \mathrm{v}$ solution in EtOAc, $0.84 \mathrm{mmol}$ ). The reaction was stirred for $0.5 \mathrm{~h}$ and then methyl 4(aminomethyl)benzoate hydrochloride ( $144 \mathrm{mg}, 0.72 \mathrm{mmol}$ ) was added. After $0.5 \mathrm{~h}$ the cold bath was removed and stirring was maintained at $\mathrm{rt}$ for $18 \mathrm{~h}$ before being diluted into DCM $(50 \mathrm{~mL})$, and then washed sequentially with an ice-cold aqueous solution of potassium hydrogen sulfate $(2 \times 20 \mathrm{~mL}$, $0.5 \mathrm{M})$, and finally brine $(15 \mathrm{~mL})$. The organic layer was dried $\left(\mathrm{Na}_{2} \mathrm{SO}_{4}\right)$ then volatiles removed under reduced pressure to provide a thick oil which was subjected to purification by flash chromatography (silica, 10:1 v/v DCM:MeOH). Concentration of the appropriate fractions afforded adduct 19 (265 $\mathrm{mg}, 89 \%)$ as a colourless foam.

$\mathbf{R}_{f}=0.4(10: 1 v / v \mathrm{DCM} / \mathrm{MeOH})$

${ }^{1} \mathbf{H}$ NMR (600 MHz, $\left.\mathbf{C D C l}_{3}\right)$ one NH not observed $\delta 7.97-7.96(\mathrm{~m}, 2 \mathrm{H}), 7.37-7.34(\mathrm{~m}, 2 \mathrm{H}), 7.31$ $-7.28(\mathrm{~m}, 2 \mathrm{H}), 7.25-7.22(\mathrm{~m}, 2 \mathrm{H}), 5.78$ (app. t, $J=5.1 \mathrm{~Hz}, 1 \mathrm{H}), 4.44$ (d, $J=5.9 \mathrm{~Hz}, 2 \mathrm{H}), 3.90$ (s, $3 \mathrm{H}), 3.03(\mathrm{t}, J=7.5 \mathrm{~Hz}, 2 \mathrm{H}), 2.53(\mathrm{t}, J=7.5 \mathrm{~Hz}, 2 \mathrm{H}), 1.60(\mathrm{~s}, 9 \mathrm{H})$.

${ }^{13} \mathbf{C}$ NMR (151 MHz, $\left.\mathbf{C D C l}_{3}\right) \delta 171.8,167.0,150.1,146.1,145.9,143.5,141.8,130.2,129.4(6)$, 129.4(5), 128.8, 127.7, 126.2, 87.0, 52.3, 43.4, 38.3, 31.4, 28.1.

LRMS (ESI $\left.{ }^{+}\right): m / z$ (rel. int.) $519(100)[\mathrm{M}+\mathrm{Na}]^{+}$.

HRMS (ESI ${ }^{+}$): calc'd for $\mathrm{C}_{25} \mathrm{H}_{28} \mathrm{~N}_{4} \mathrm{NaO}_{7}[\mathrm{M}+\mathrm{Na}]^{+}: 519.1850$, found: 519.1852 . 
A magnetically stirred solution of $\mathbf{1 9}(150 \mathrm{mg}, 0.91 \mathrm{mmol})$ in DCM $(5 \mathrm{~mL})$ maintained in an ice-bath was treated with TFA $(1.8 \mathrm{~mL})$. After $0.1 \mathrm{~h}$ the mixture was warmed to $\mathrm{rt}$ and stirring continued for $0.75 \mathrm{~h}$. The majority of the volatiles were removed with a gentle stream of nitrogen and then the residue was re-dissolved in DCM (ca. $1 \mathrm{~mL}$ ) and precipitated with 1:1 v/v diethyl ether/pet. spirit $(10 \mathrm{~mL})$. The solution was decanted from the sticky gum and the precipitation process was repeated. The resulting gum was subjected to reduced pressure $(\sim 0.8 \mathrm{mmHg})$ for $18 \mathrm{~h}$ which afforded $\mathbf{S - 1 3}$ (109 $\mathrm{mg}, 92 \%)$ as a crisp foam and used without further purification.

${ }^{1}$ H NMR (700 MHz, DMSO-d $\left.\boldsymbol{d}_{\mathbf{6}}\right) \delta 10.43(\mathrm{~s}, 2 \mathrm{H}), 8.45(\mathrm{t}, J=6.0 \mathrm{~Hz}, 1 \mathrm{H}), 7.91-7.87(\mathrm{~m}, 2 \mathrm{H}), 7.35$ -7.27 (m, 6H), 4.33 (d, $J=5.9 \mathrm{~Hz}, 2 \mathrm{H}), 3.84(\mathrm{~s}, 3 \mathrm{H}), 2.90$ (t, $J=7.6 \mathrm{~Hz}, 2 \mathrm{H}), 2.51$ (t, $J=7.6 \mathrm{~Hz}$, $2 \mathrm{H})$.

${ }^{13}$ C NMR (176 MHz, DMSO-d $\left.\mathbf{d}\right) \delta$ 171.4, 166.1, 153.5, 145.2, 140.8, 129.8, 129.2, 128.7, 128.1, $127.3,125.9,52.0,41.8,36.7,30.6$.

LRMS (ESI $\left.{ }^{-}\right): m / z$ (rel. int.) 395 (100) $[\mathrm{M}-\mathrm{H}]^{-}$.

HRMS (ESI ${ }^{+}$): calc'd for $\mathrm{C}_{20} \mathrm{H}_{20} \mathrm{~N}_{4} \mathrm{NaO}_{5}[\mathrm{M}+\mathrm{Na}]^{+}: 419.1326$, found: 419.1335

IR: $\mathrm{V}_{\max }=1718,1690,1278,1103,755 \mathrm{~cm}^{-1}$. 


\section{TAD cycloadduct $\mathbf{2 8}$}

A magnetically and vigorously-stirred suspension of $\mathbf{S - 1 3}(129 \mathrm{mg}, 0.33 \mathrm{mmol})$ in DCM $(10 \mathrm{~mL})$ maintained at $\mathrm{rt}$, was charged sequentially with powdered $\mathrm{KBr}(12 \mathrm{mg}, 99 \mu \mathrm{mol})$, Oxone $(264 \mathrm{mg}$, $0.43 \mathrm{mmol})$ then water $(100 \mu \mathrm{L})$. The suspension was stirred vigorously and after $1 \mathrm{~h}$, the red mixture was filtered through a $0.45 \mu \mathrm{m}$ nylon syringe filter and the filtrate collected. The volatiles were removed with a gentle stream of nitrogen to afford a red solid which was immediately dissolved in THF $(5 \mathrm{~mL})$ and treated with a solution of $N$-methoxy- $N$-methylbicyclo[1.1.0]butane-1-carboxamide (4) $(92 \mathrm{mg}, 0.65 \mathrm{mmol})$ in ether $(1.5 \mathrm{~mL})$. After stirring for $1 \mathrm{~h}$ the colourless mixture was concentrated under reduced pressure with a gentle stream of nitrogen and the ensuing residue was subjected to purification by flash chromatography (silica, 7:1.5:1.5 v/v/v DCM/EtOAc/Acetone). Concentration of the appropriate fractions afforded $28(39 \mathrm{mg}, 22 \%)$ as a colourless foam.

$\mathbf{R}_{\boldsymbol{f}}=0.4(7: 1.5: 1.5 v / v / v$ DCM/EtOAc/Acetone $)$

${ }^{1}$ H NMR (700 MHz, CDCl $) \delta 7.94-7.92(\mathrm{~m}, 2 \mathrm{H}), 7.36-7.34(\mathrm{~m}, 2 \mathrm{H}), 7.27-7.24(\mathrm{~m}, 2 \mathrm{H}), 7.23$ $-7.21(\mathrm{~m}, 2 \mathrm{H}), 6.03$ (app. t, $J=6.1 \mathrm{~Hz}, 1 \mathrm{H}), 4.74-4.73(\mathrm{~m}, 1 \mathrm{H}), 4.41(\mathrm{~d}, J=5.9 \mathrm{~Hz}, 2 \mathrm{H}), 3.88$ (s, $3 \mathrm{H}), 3.38$ (s, 3H), 3.28 (br s, 3H), 2.99 (t, $J=7.6 \mathrm{~Hz}, 2 \mathrm{H}), 2.52-2.49$ (m, 2H), 2.50 (t, $J=7.6 \mathrm{~Hz}$, $2 \mathrm{H}), 2.21-2.14(\mathrm{~m}, 2 \mathrm{H})$.

${ }^{13}$ C NMR (176 MHz, CDCl $\mathbf{C}_{3} \delta 171.8,166.9,164.3,159.5,158.9,143.6,141.7,130.0,129.5$, 129.3(4), 129.3(4), 127.6, 125.5, 73.5, 62.3, 59.6, 52.2, 43.4, 43.3, 38.1, 32.7, 31.3.

LRMS (ESI $\left.{ }^{+}\right): m / z$ (rel. int.) $558(100)[\mathrm{M}+\mathrm{Na}]^{+}$.

HRMS (ESI ${ }^{+}$): calc'd for $\mathrm{C}_{27} \mathrm{H}_{29} \mathrm{~N}_{5} \mathrm{NaO}_{7}[\mathrm{M}+\mathrm{Na}]^{+}: 558.1959$, found: 558.1952 .

Alanine cycloadduct 29
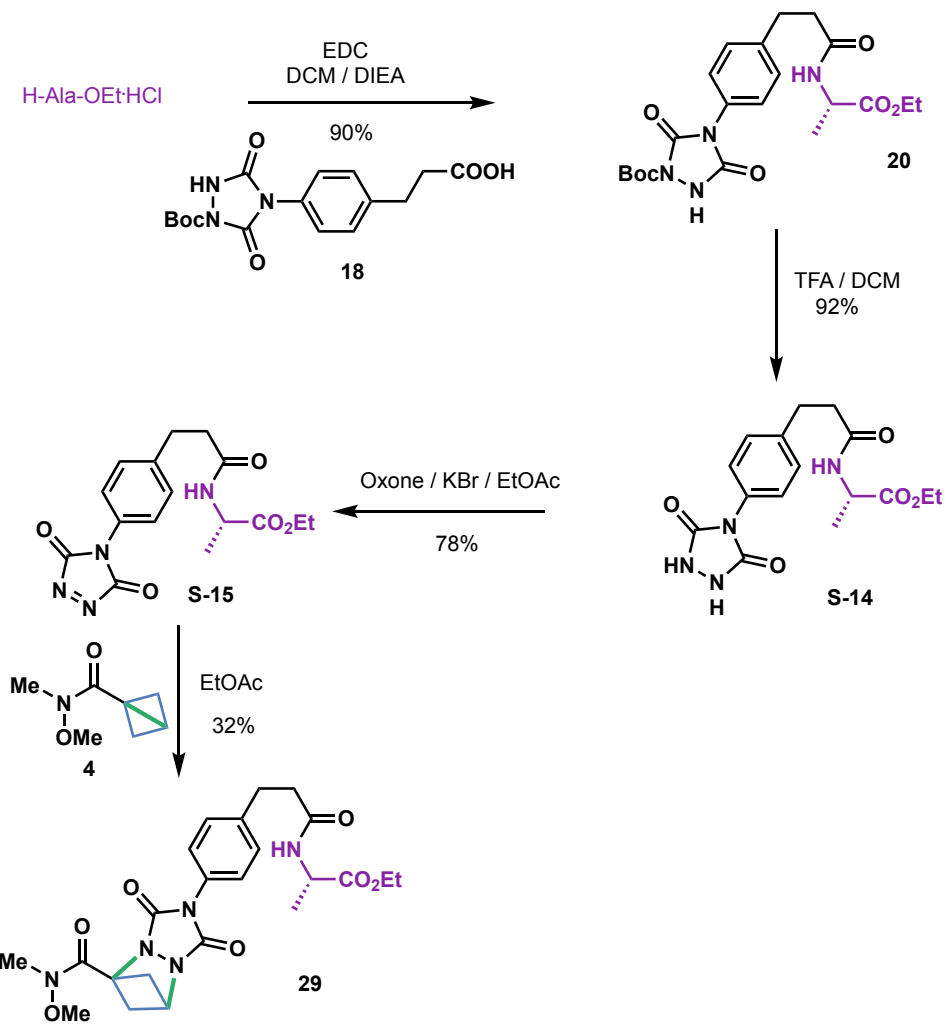
A magnetically stirred suspension of $18(349 \mathrm{mg}, 1.00 \mathrm{mmol})$ in $\mathrm{DCM}(10 \mathrm{~mL})$, maintained at $0{ }^{\circ} \mathrm{C}$ (ice-bath) was treated sequentially with $\mathrm{HOBt}(149 \mathrm{mg}, 1.10 \mathrm{mmol})$, DIEA $(191 \mu \mathrm{L}, 1.10 \mathrm{mmol})$ then EDC $(211 \mathrm{mg}, 1.10 \mathrm{mmol})$. After $0.5 \mathrm{~h}$, a subsequent aliquot of DIEA $(191 \mu \mathrm{L}, 1.10 \mathrm{mmol})$ was added, followed by alanine ethyl ester hydrochloride $(169 \mathrm{mg}, 1.10 \mathrm{mmol})$ and then a final aliquot of DIEA $(191 \mu \mathrm{L}, 1.10 \mathrm{mmol})$. The cold bath was removed and stirring was maintained at $\mathrm{rt}$ for $4 \mathrm{~h}$ before being diluted into DCM $(30 \mathrm{~mL})$ and then washed sequentially with an ice-cold aqueous solution of potassium hydrogen sulfate $(2 \times 15 \mathrm{~mL}, 0.5 \mathrm{M})$, Dulbecco's phosphate buffered saline $(2 \times 10 \mathrm{~mL}, \mathrm{pH} 7.4)$ then brine $(15 \mathrm{~mL})$. The organic layer was dried $\left(\mathrm{Na}_{2} \mathrm{SO}_{4}\right)$, concentrated under reduced pressure and the residue so obtained was purified by flash chromatography (silica, 1:10 v/v $\mathrm{MeOH} / \mathrm{DCM}$ ) to afford $\mathbf{2 0}$ (406 $\mathrm{mg}, 90 \%$ ) as a white solid.

$\mathbf{R}_{f}=0.5(1: 10 v / v \mathrm{MeOH} / \mathrm{DCM})$

$[\boldsymbol{\alpha}]_{\boldsymbol{D}}^{\mathbf{2 2}}+10.3(c=0.9, \mathrm{MeOH})$.

${ }^{1} \mathbf{H}$ NMR (400 MHz, $\left.\mathbf{C D C l}_{3}\right)$ one NH not observed $\delta 7.38-7.33(\mathrm{~m}, 2 \mathrm{H}), 7.31-7.25(\mathrm{~m}, 2 \mathrm{H}), 6.27$ $(\mathrm{d}, J=7.5 \mathrm{~Hz}, 1 \mathrm{H}), 4.63-4.53(\mathrm{~m}, 1 \mathrm{H}), 4.20(\mathrm{q}, J=7.2 \mathrm{~Hz}, 2 \mathrm{H}), 3.04-2.93(\mathrm{~m}, 2 \mathrm{H}), 2.57-2.43$ $(\mathrm{m}, 2 \mathrm{H}), 1.58(\mathrm{~s}, 9 \mathrm{H}), 1.36(\mathrm{~d}, J=7.1 \mathrm{~Hz}, 3 \mathrm{H}), 1.27(\mathrm{t}, J=7.2 \mathrm{~Hz}, 3 \mathrm{H})$.

${ }^{13}$ C NMR (101 MHz, $\left.\mathbf{C D C l}_{3}\right) \delta 173.5,171.5,150.4,146.2,145.8,141.9,129.4,128.6,126.2,86.9$, $61.7,48.2,37.9,31.2,28.1,18.7,14.2$.

LRMS (ESI $\left.{ }^{+}\right): m / z$ (rel. int.) $471(100)[\mathrm{M}+\mathrm{Na}]^{+}$.

HRMS (ESI ${ }^{+}$): calc'd for $\mathrm{C}_{21} \mathrm{H}_{28} \mathrm{~N}_{4} \mathrm{NaO}_{7}[\mathrm{M}+\mathrm{Na}]^{+}: 471.1850$, found: 471.1846 .

IR: $\mathrm{V}_{\max }=1736,1304,1132,752 \mathrm{~cm}^{-1}$.

Alanine urazole adduct $\mathbf{S - 1 4}$

A magnetically stirred solution of $\mathbf{2 0}(406 \mathrm{mg}, 0.91 \mathrm{mmol})$ in DCM $(10 \mathrm{~mL})$ maintained in an icebath, was treated with TFA $(4 \mathrm{~mL})$. After $0.1 \mathrm{~h}$ the mixture was warmed to $\mathrm{rt}$ and stirring continued for $0.75 \mathrm{~h}$ after which time TLC revealed complete consumption of the starting material. The solvent was removed with a gentle stream of nitrogen and the thick oil obtained was subjected to purification by flash chromatography (silica, 45:6:0.2 $v / v / v$ DCM/MeOH/AcOH). Concentration of the appropriate fractions afforded $\mathbf{S - 1 4}(270 \mathrm{mg}, 85 \%)$ as a colourless foam.

$[\boldsymbol{\alpha}]_{\boldsymbol{D}}^{23}-25.0(c=1.0, \mathrm{MeOH})$. 
${ }^{1}$ H NMR (400 MHz, DMSO-d $\left.\mathbf{d}_{\mathbf{6}}\right) \delta 10.40(\mathrm{~s}, 2 \mathrm{H}), 8.29(\mathrm{~d}, J=7.0 \mathrm{~Hz}, 1 \mathrm{H}), 7.35-7.29(\mathrm{~m}, 4 \mathrm{H}), 4.26$ $-4.19(\mathrm{~m}, 1 \mathrm{H}), 4.13-4.02(\mathrm{~m}, 2 \mathrm{H}), 2.88-2.82(\mathrm{~m}, 2 \mathrm{H}), 2.47-2.41(\mathrm{~m}, 2 \mathrm{H}), 1.24(\mathrm{~d}, J=7.3 \mathrm{~Hz}$, $3 \mathrm{H}), 1.17$ (t, $J=7.1 \mathrm{~Hz}, 3 \mathrm{H})$.

${ }^{13}$ C NMR (101 MHz, DMSO-d $\left.\mathbf{d}_{\mathbf{6}}\right) \delta$ 172.7, 171.2, 153.5, 140.9, 129.7, 128.6, 125.9, 60.4, 47.6, 36.3, $30.5,17.0,14.1$.

LRMS (ESI $\left.{ }^{+}\right): m / z$ (rel. int.) $371(100)[\mathrm{M}+\mathrm{Na}]^{+}$.

HRMS (ESI $\left.{ }^{+}\right)$: calc'd for $\mathrm{C}_{16} \mathrm{H}_{20} \mathrm{~N}_{4} \mathrm{NaO}_{5}[\mathrm{M}+\mathrm{Na}]^{+}: 371.1326$, found: 371.1330 .

IR: $\mathrm{V}_{\max }=3344,1708,1649,1227,597 \mathrm{~cm}^{-1}$.

\section{Alanine TAD adduct $\mathbf{S - 1 5}$}

Procedure adapted from Zolfigol and co-workers. ${ }^{5}$ A magnetically and vigorously-stirred suspension of S-14 $(80 \mathrm{mg}, 0.23 \mathrm{mmol})$ in DCM $(10 \mathrm{~mL})$ maintained at $\mathrm{rt}$, was charged sequentially with powdered $\mathrm{KBr}(22 \mathrm{mg}, 0.18 \mathrm{mmol})$, Oxone $(163 \mathrm{mg}, 0.27 \mathrm{mmol})$ then water $(100 \mu \mathrm{L})$. The suspension was stirred vigorously and after $0.5 \mathrm{~h}$, the red mixture was filtered, and the filtrate collected. The volatiles were removed with a gentle stream of nitrogen to afford S-15 (62 mg, 78\% at ca. 80\% purity) as a red solid which was used immediately in the procedure described below, and without further purification.

${ }^{1} \mathrm{H}$ NMR (400 MHz, $\left.\mathbf{C D C l}_{3}\right) \delta 7.36-7.31(\mathrm{~m}, 4 \mathrm{H}), 6.19(\mathrm{~d}, J=7.5 \mathrm{~Hz}, 1 \mathrm{H}), 4.55-4.47(\mathrm{~m}, 1 \mathrm{H})$, 4.15 (q, $J=7.1 \mathrm{~Hz}, 2 \mathrm{H}), 2.98$ (app. t, $J=7.7 \mathrm{~Hz}, 2 \mathrm{H}), 2.51$ (td, $J=7.6,4.7 \mathrm{~Hz}, 2 \mathrm{H}), 1.32$ (d, $J=7.2$ $\mathrm{Hz}, 3 \mathrm{H}), 1.25$ (t, $J=7.1 \mathrm{~Hz}, 3 \mathrm{H})$.

${ }^{13}$ C NMR (101 MHz, $\left.\mathbf{C D C l}_{3}\right) \delta 173.3,171.3,158.0,142.6,129.9,127.7,124.2,61.7,48.2,37.6$, $31.0,18.5,14.2$.

\section{Alanine cycloadduct $\mathbf{2 9}$}

A magnetically stirred solution of S-15 $(60 \mathrm{mg}, 173 \mu \mathrm{mol})$ in EtOAc $(7 \mathrm{~mL})$ maintained at $\mathrm{rt}$ was treated with a solution of $N$-methoxy- $N$-methylbicyclo[1.1.0]butane-1-carboxamide (4) $(32 \mathrm{mg}$, $226 \mu \mathrm{mol})$ in ether $(1 \mathrm{~mL})$. After $2 \mathrm{~h}$ the solvent was removed with a gentle stream of nitrogen and the residue so obtained was subjected to purification by flash chromatography (silica, 70:15:15 v/v/ $\mathrm{DCM} / \mathrm{EtOAc} / \mathrm{acetone})$. Concentration of the appropriate fractions afforded $\mathbf{2 9}(27 \mathrm{mg}, 32 \%)$ as a colourless foam.

$\mathbf{R}_{f}=0.2(4: 6 v / v \mathrm{DCM} / \mathrm{EtOAc})$

$[\alpha]_{D}^{22}+2.76(c=1.3, \mathrm{MeOH})$.

${ }^{1}$ H NMR (400 MHz, CDCl $) \delta 7.41-7.37$ (m, 2H), $7.31-7.27$ (m, 2H), 5.98 (d, J= 7.3 Hz, 1H), 4.75 (app. t, $J=2.0 \mathrm{~Hz}, 1 \mathrm{H}$ ), 4.55 (app. p, $J=7.2 \mathrm{~Hz}, 1 \mathrm{H}$ ), 4.19 (q, $J=7.1 \mathrm{~Hz}, 2 \mathrm{H}$ ), 3.84 (s, 3H), 
$3.31(\mathrm{~s}, 3 \mathrm{H}), 3.05-2.93(\mathrm{~m}, 2 \mathrm{H}), 2.57-2.43(\mathrm{~m}, 4 \mathrm{H}), 2.24-2.16(\mathrm{~m}, 2 \mathrm{H}), 1.35(\mathrm{~d}, J=7.1 \mathrm{~Hz}, 3 \mathrm{H})$, $1.27(\mathrm{t}, J=7.1 \mathrm{~Hz}, 3 \mathrm{H})$.

${ }^{13}$ C NMR (101 MHz, $\left.\mathbf{C D C l}_{3}\right) \delta 173.1,171.0,164.1,159.4,158.7,141.5,129.4,129.2,125.3,73.4$, $62.1,61.5,59.5,48.1,43.3,37.9,32.6,31.0,29.7,18.6,14.1$.

LRMS (ESI $\left.{ }^{+}\right): m / z$ (rel. int.) $510(100)[\mathrm{M}+\mathrm{Na}]^{+}$.

HRMS (ESI ${ }^{+}$): calc'd for $\mathrm{C}_{23} \mathrm{H}_{29} \mathrm{~N}_{5} \mathrm{NaO}_{7}[\mathrm{M}+\mathrm{Na}]^{+}: 510.1959$, found: 510.1961 .

IR: $\mathrm{V}_{\max }=1725,1659,1399 \mathrm{~cm}^{-1}$.

Phe-Ala-OEt TAD cycloadduct $\mathbf{3 0}$
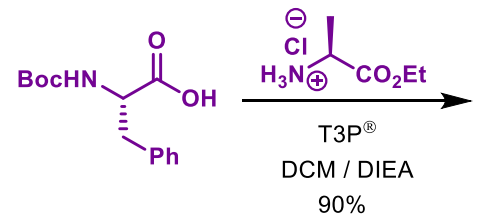

BocHN<smiles>C=C(NCC)C(I)Cc1ccccc1</smiles><smiles>CCCCC(=O)OCC</smiles>

S-16

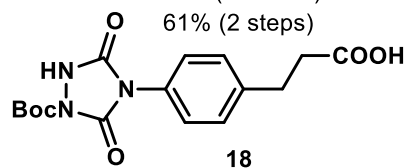

18
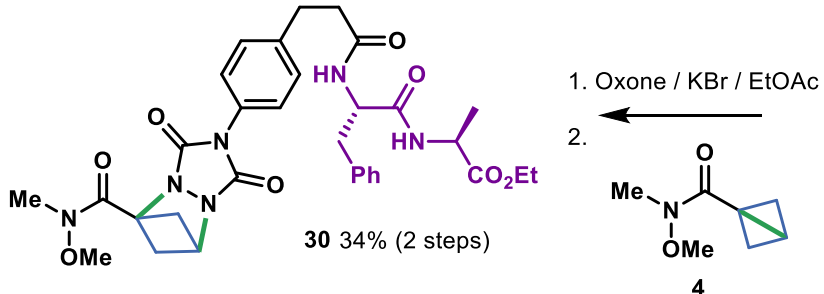
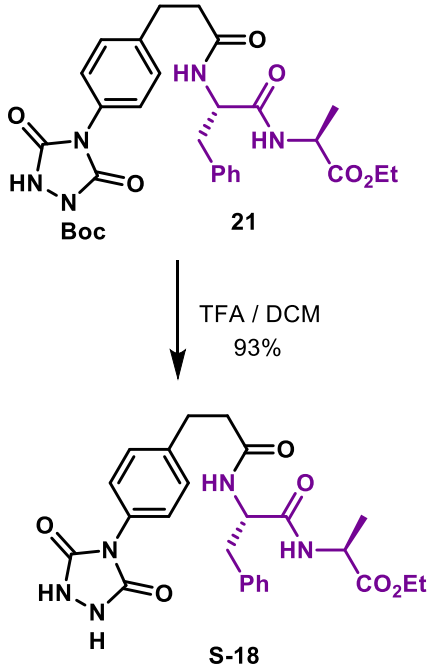

Boc-Phe-Ala-OEt S-16

A magnetically stirred suspension of Boc-L-phenylalanine $(862 \mathrm{mg}, 3.26 \mathrm{mmol})$ in DCM $(20 \mathrm{~mL})$ maintained at $0{ }^{\circ} \mathrm{C}$ (ice-bath) was treated sequentially with DIEA $(1.73 \mathrm{~mL}, 9.75 \mathrm{mmol})$, then T3P ${ }^{\circledR}$ $(2.59 \mathrm{~mL}$ of a $50 \% \mathrm{w} / \mathrm{v}$ solution in EtOAc, $6.88 \mathrm{mmol})$. The reaction was stirred for $0.5 \mathrm{~h}$ and then $L$-alanine ethyl ester hydrochloride was added $(500 \mathrm{mg}, 3.26 \mathrm{mmol})$. After $0.5 \mathrm{~h}$ the cold bath was removed and stirring was maintained at $\mathrm{rt}$ for $18 \mathrm{~h}$ before being diluted into DCM $(50 \mathrm{~mL})$, and then the organic phase was washed sequentially with an ice-cold aqueous solution of potassium hydrogen sulfate $(2 \times 20 \mathrm{~mL}, 1 \mathrm{M})$, saturated aqueous solution of sodium hydrogen carbonate $(2 \times 20 \mathrm{~mL})$ and finally brine $(15 \mathrm{~mL})$. The organic layer was dried $\left(\mathrm{Na}_{2} \mathrm{SO}_{4}\right)$ then volatiles removed under reduced pressure to provide a thick oil which was subjected to purification by flash chromatography (silica, 1.5:3.5 v/v EtOAc:DCM). Concentration of the appropriate fractions afforded Boc-Phe-Ala-OEt S-16 $(1.07 \mathrm{~g}, 90 \%)$ as a colourless foam.

$[\alpha]_{D}^{22}+3.3\left(c=1, \mathrm{CDCl}_{3}\right)$. 
${ }^{1} \mathbf{H}$ NMR (400 MHz, $\left.\mathbf{C D C l}_{3}\right) \delta 7.32-7.17(\mathrm{~m}, 5 \mathrm{H}), 6.43(\mathrm{~d}, J=7.2 \mathrm{~Hz}, 1 \mathrm{H}), 5.05-4.91(\mathrm{~m}, 1 \mathrm{H})$, $4.53-4.44(\mathrm{~m}, 1 \mathrm{H}), 4.42-4.30(\mathrm{~m}, 1 \mathrm{H}), 4.22-4.11(\mathrm{~m}, 2 \mathrm{H}), 3.13-3.01(\mathrm{~m}, 2 \mathrm{H}), 1.41(\mathrm{~s}, 9 \mathrm{H}), 1.34$ $(\mathrm{d}, J=7.1 \mathrm{~Hz}, 3 \mathrm{H}), 1.26(\mathrm{t}, J=7.1 \mathrm{~Hz}, 3 \mathrm{H})$.

${ }^{13} \mathbf{C}$ NMR (101 MHz, $\left.\mathbf{C D C l}_{3}\right) \delta=172.5,170.8,155.4,136.7,129.5,128.8,127.1,80.4,61.6,55.7$, $48.3,38.5,28.4,18.6,14.2$.

LRMS (ESI $\left.{ }^{+}\right): m / z$ (rel. int.) $387(100)[\mathrm{M}+\mathrm{Na}]^{+}$.

HRMS (ESI ${ }^{+}$): calc'd for $\mathrm{C}_{19} \mathrm{H}_{28} \mathrm{~N}_{2} \mathrm{NaO}_{5}[\mathrm{M}+\mathrm{Na}]^{+}: 387.1890$, found: 387.1896 .

IR: $\mathrm{V}_{\max }=1744,1656,1538 \mathrm{~cm}^{-1}$.

\section{Phe-Ala-OEt Boc-urazole 21}

A magnetically stirred solution of $\mathbf{S - 1 6}(395 \mathrm{mg}, 1.08 \mathrm{mmol})$ in DCM (4 mL) maintained in an icebath, was treated with TFA $(4 \mathrm{~mL})$. After $0.1 \mathrm{~h}$ the mixture was warmed to $\mathrm{rt}$ and stirring continued for $0.75 \mathrm{~h}$. The majority of the volatiles were removed with a gentle stream of nitrogen and then the residue re-dissolved in DCM (ca. $5 \mathrm{~mL}$ ) and precipitated with diethyl ether $(15 \mathrm{~mL})$. The ensuing gum was then subjected to reduced pressure $(\sim 5 \mathrm{mmHg})$ for $5 \mathrm{~h}$ which afforded the deprotected, amine trifluoroacetic acid salt $\mathbf{S - 1 7}$ as a crisp foam which was used directly in the amide bondforming process described directly below. In a separate flask, a magnetically stirred solution of carboxylic acid $18(349 \mathrm{mg}, 1.00 \mathrm{mmol})$ in DCM $(10 \mathrm{~mL})$, maintained at $0{ }^{\circ} \mathrm{C}$ (ice-bath) was treated sequentially with, HOBt $(149 \mathrm{mg}, 1.10 \mathrm{mmol})$, DIEA $(191 \mu \mathrm{L}, 1.10 \mathrm{mmol})$ then EDC $(211 \mathrm{mg}$, $1.10 \mathrm{mmol}$ ). The mixture was stirred for $0.5 \mathrm{~h}$ then a mixture of the above formed TFA salt (S-17), DIEA ( $376 \mu \mathrm{L} \mathrm{mL}, 2.16 \mathrm{mmol})$ and DCM $(10 \mathrm{~mL})$ was added and stirring maintained for $18 \mathrm{~h}$. The reaction mixture was then diluted with DCM $(50 \mathrm{~mL})$ and brine $(15 \mathrm{~mL})$. The organic layer was dried $\left(\mathrm{Na}_{2} \mathrm{SO}_{4}\right)$, concentrated under reduced pressure and the ensuing residue purified by flash chromatography (silica, 45:6:0.2 v/v/v DCM/MeOH/AcOH) to provide 21 (390 mg, 61\%, 2 steps) as a colourless gum.

Data for amine trifluoroacetic acid salt of H-Phe-Ala-OEt S-17

${ }^{1}$ H NMR (400 MHz, DMSO-d $) \delta 8.91$ (d, $\left.J=7.2 \mathrm{~Hz}, 1 \mathrm{H}\right), 8.15$ (br s, 3H), 7.37 - 7.24 (m, 5H), 4.41 $-4.29(\mathrm{~m}, 1 \mathrm{H}), 4.10(\mathrm{q}, J=7.1 \mathrm{~Hz}, 2 \mathrm{H}), 4.06-3.98(\mathrm{~m}, 1 \mathrm{H}), 3.13(\mathrm{dd}, J=14.1,5.4 \mathrm{~Hz}, 1 \mathrm{H}), 2.93$ (dd, $J=14.1,8.1 \mathrm{~Hz}, 1 \mathrm{H}), 1.32$ (d, $J=7.2 \mathrm{~Hz}, 3 \mathrm{H}), 1.19$ (t, $J=7.1 \mathrm{~Hz}, 3 \mathrm{H})$.

${ }^{13}$ C NMR (101 MHz, DMSO-d $\left.\boldsymbol{d}_{\mathbf{6}}\right) \delta 171.8,167.9,158.2\left(\mathrm{q},{ }^{2} J_{C-F}=35.9 \mathrm{~Hz}\right), 134.8,129.5,128.6$, $127.2,115.8\left(\mathrm{q}, J_{C-F}=293.1 \mathrm{~Hz}\right), 60.8,53.3,47.8,36.9,17.0,14.0$.

LRMS (ESI $\left.{ }^{+}\right): m / z$ (rel. int.) $265(100)[\mathrm{M}+\mathrm{H}]^{+}$.

Data for adduct $\mathbf{2 1}$

$[\alpha]_{\mathbf{D}}^{23}-1.4\left(\mathrm{c}=0.5, \mathrm{CDCl}_{3}\right)$.

${ }^{1}$ H NMR (400 MHz, $\left.\mathbf{C D C l}_{3}\right) \delta 10.61$ (br s, 1H), 7.61 (d, $\left.J=8.5 \mathrm{~Hz}, 1 \mathrm{H}\right), 7.30-7.06(\mathrm{~m}, 10 \mathrm{H}), 4.92$ $-4.84(\mathrm{~m}, 1 \mathrm{H}), 4.51-4.41(\mathrm{~m}, 1 \mathrm{H}), 4.11(\mathrm{q}, J=7.0 \mathrm{~Hz}, 2 \mathrm{H}), 3.04(\mathrm{dd}, J=13.8,6.5 \mathrm{~Hz}, 1 \mathrm{H}), 2.95$ $(\mathrm{dd}, J=13.8,7.2 \mathrm{~Hz}, 1 \mathrm{H}), 2.86-2.74(\mathrm{~m}, 2 \mathrm{H}), 2.48-2.36(\mathrm{~m}, 2 \mathrm{H}), 1.54(\mathrm{~s}, 9 \mathrm{H}), 1.31(\mathrm{~d}, J=7.2 \mathrm{~Hz}$, $3 \mathrm{H}), 1.20(\mathrm{t}, J=6.9 \mathrm{~Hz}, 3 \mathrm{H})$. 
${ }^{13}$ C NMR (101 MHz, $\left.\mathbf{C D C l}_{3}\right) \delta 172.5,172.2,171.9,150.7,146.3,145.6,141.8,136.5,129.6,129.2$, $128.7,128.4,126.9,126.0,86.3,61.6,54.2,48.4,38.8,38.1,31.8,28.1,18.1,14.2$.

LRMS (ESI $\left.{ }^{+}\right): m / z$ (rel. int.) $618(100)[\mathrm{M}+\mathrm{Na}]^{+}$.

HRMS (ESI ${ }^{+}$): calc'd for $\mathrm{C}_{30} \mathrm{H}_{37} \mathrm{~N}_{5} \mathrm{NaO}_{8}[\mathrm{M}+\mathrm{Na}]^{+}: 618.2534$, found: 618.2547.

IR: $\mathrm{V}_{\max }=1725,1638,1307,1133,730 \mathrm{~cm}^{-1}$.

\section{Phe-Ala urazole adduct S-18}

A magnetically stirred solution of $21(384 \mathrm{mg}, 2.32 \mathrm{mmol})$ in DCM $(10 \mathrm{~mL})$ maintained in an icebath, was treated with TFA $(4 \mathrm{~mL})$. After $0.1 \mathrm{~h}$ the mixture was warmed to $\mathrm{rt}$ and stirring continued for $0.75 \mathrm{~h}$. The majority of the volatiles were removed with a gentle stream of nitrogen and then the residue was re-dissolved in DCM (ca. $5 \mathrm{~mL}$ ) and precipitated with 1:1 v/v diethyl ether/pet. spirit $(15 \mathrm{~mL})$. The solution was decanted from the sticky gum and the precipitation process was repeated and the resulting gum was subjected to reduced pressure $(\sim 0.8 \mathrm{mmHg})$ for $24 \mathrm{~h}$ which afforded $\mathbf{S - 1 8}$ (297 $\mathrm{mg}, 93 \%$ ) as a crisp foam used without further purification.

$[\alpha]_{\mathrm{D}}^{22}-22.3(\mathrm{c}=1.0, \mathrm{MeOH})$.

${ }^{1}$ H NMR (400 MHz, Methanol-d $\left.\boldsymbol{d}_{4}\right) 4$ NHs not observed $\delta 7.34-7.30(\mathrm{~m}, 2 \mathrm{H}), 7.29-7.17(\mathrm{~m}, 7 \mathrm{H})$, $4.68(\mathrm{dd}, J=9.5,5.1 \mathrm{~Hz}, 1 \mathrm{H}), 4.38(\mathrm{q}, J=7.3 \mathrm{~Hz}, 1 \mathrm{H}), 4.16(\mathrm{q}, J=7.1 \mathrm{~Hz}, 2 \mathrm{H}), 3.15(\mathrm{dd}, J=14.0$, $5.2 \mathrm{~Hz}, 1 \mathrm{H}), 2.87-2.79(\mathrm{~m}, 3 \mathrm{H}), 2.52-2.40(\mathrm{~m}, 2 \mathrm{H}), 1.37(\mathrm{~d}, J=7.3 \mathrm{~Hz}, 3 \mathrm{H}), 1.25(\mathrm{t}, J=7.1 \mathrm{~Hz}$, $3 \mathrm{H})$.

${ }^{13}$ C NMR (101 MHz, Methanol- $\left.\boldsymbol{d}_{4}\right) \delta$ 174.8, 174.0, 173.5, 155.8, 142.6, 138.5, 130.9, 130.3, 130.0, $129.4,127.7,127.3,62.3,55.6,49.6,39.0,38.2,32.2,17.4,14.5$.

LRMS (ESI'): $m / z$ (rel. int.) $494(100)[\mathrm{M}-\mathrm{H}]^{-}$.

HRMS (ESI'): calc'd for : $\mathrm{C}_{25} \mathrm{H}_{28} \mathrm{~N}_{5} \mathrm{O}_{6}[\mathrm{M}-\mathrm{H}]^{-}: 494.2045$, found: 494.2037.

IR: $\mathrm{V}_{\max }=1725,1638,1307,1133 \mathrm{~cm}^{-1}$.

Phe-Ala-OEt TAD cycloadduct 30

A magnetically and vigorously-stirred suspension of $\mathbf{S - 1 8}(159 \mathrm{mg}, 0.32 \mathrm{mmol})$ in DCM $(10 \mathrm{~mL})$ maintained at $\mathrm{rt}$, was charged sequentially with powdered $\mathrm{KBr}(11 \mathrm{mg}, 84 \mu \mathrm{mol})$, Oxone (236 mg, $0.38 \mathrm{mmol})$ then water $(100 \mu \mathrm{L})$. The suspension was stirred vigorously and after $0.5 \mathrm{~h}$, the redcoloured mixture was filtered through a $0.45 \mu \mathrm{m}$ nylon syringe filter and the filtrate collected. The volatiles were removed with a gentle stream of nitrogen to afford a red solid which was immediately dissolved in ethyl acetate $(10 \mathrm{~mL})$ and treated with a solution of $N$-methoxy- $N$ methylbicyclo[1.1.0]butane-1-carboxamide (4) $(90 \mathrm{mg}, 0.64 \mathrm{mmol})$ in ether (2 mL). After stirring for $1.5 \mathrm{~h}$ the colourless mixture was concentrated under reduced pressure with a gentle stream of nitrogen and the ensuing residue was subjected to purification by flash chromatography (silica, 10:0.5 v/ 
$\mathrm{DCM} / \mathrm{MeOH})$. Concentration of the appropriate fractions afforded $\mathbf{3 0}(69 \mathrm{mg}, 34 \%)$ as a colourless foam.

$[\alpha]_{D}^{22}-15.7(c=1.3, \mathrm{MeOH})$.

$\mathbf{R}_{f}=0.4(10: 0.5 v / v \mathrm{DCM} / \mathrm{MeOH})$

${ }^{1}$ H NMR (700 MHz, CDCl $) \delta 7.41-7.37(\mathrm{~m}, 2 \mathrm{H}), 7.29-7.21(\mathrm{~m}, 5 \mathrm{H}), 7.19-7.16(\mathrm{~m}, 2 \mathrm{H}), 6.41$ $(\mathrm{d}, J=7.1 \mathrm{~Hz}, \mathrm{NH}), 6.22$ (d, $J=7.8 \mathrm{~Hz}, \mathrm{NH}), 4.76$ (app. t, $J=1.6 \mathrm{~Hz}, 1 \mathrm{H}), 4.69$ (q, $J=7.2 \mathrm{~Hz}, 1 \mathrm{H})$, $4.46-4.42(\mathrm{~m}, 1 \mathrm{H}), 4.21-4.15(\mathrm{~m}, 2 \mathrm{H}), 3.85(\mathrm{~s}, 3 \mathrm{H}), 3.31(\mathrm{br} \mathrm{s}, 3 \mathrm{H}), 3.05(\mathrm{dd}, J=13.9,6.5 \mathrm{~Hz}$, $1 \mathrm{H}), 3.02(\mathrm{dd}, J=13.9,7.2 \mathrm{~Hz}, 1 \mathrm{H}), 2.95-2.91(\mathrm{~m}, 2 \mathrm{H}), 2.57-2.52(\mathrm{~m}, 2 \mathrm{H}), 2.51-2.42(\mathrm{~m}, 2 \mathrm{H})$, $2.24-2.18$ (m, 2H), 1.34 (d, $J=7.1 \mathrm{~Hz}, 3 \mathrm{H}), 1.27$ (t, $J=7.1 \mathrm{~Hz}, 3 \mathrm{H})$.

${ }^{13}$ C NMR (176 MHz, $\left.\mathbf{C D C l}_{3}\right) \delta 172.4,171.7,170.4,164.3,159.5,158.8,141.5,136.5,129.5,129.4$, 129.2 , 128.7, 127.1, 125.4, 73.5, 62.2, 61.6, 59.6, 54.3, 48.4, 43.4, 38.5, 37.8, 32.7, 31.0, 18.4, 14.2.

LRMS (ESI $\left.{ }^{+}\right): m / z$ (rel. int.) $657(100)[\mathrm{M}+\mathrm{Na}]^{+}$.

HRMS (ESI ${ }^{+}$): calc'd for $\mathrm{C}_{32} \mathrm{H}_{38} \mathrm{~N}_{6} \mathrm{NaO}_{8}[\mathrm{M}+\mathrm{Na}]^{+}:$657.2643, found: 657.2645.

Ser(OBn)-Phe-Lys(Cbz)-OMe TAD cycloadduct $\mathbf{3 1}$

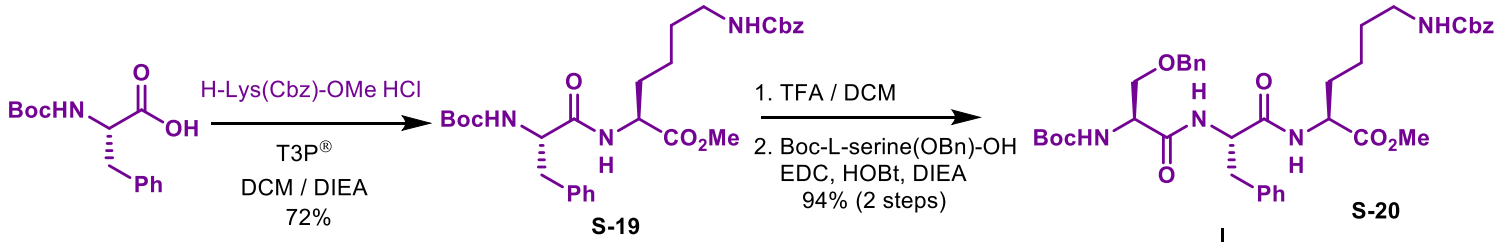

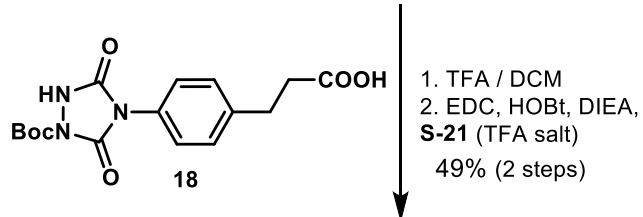

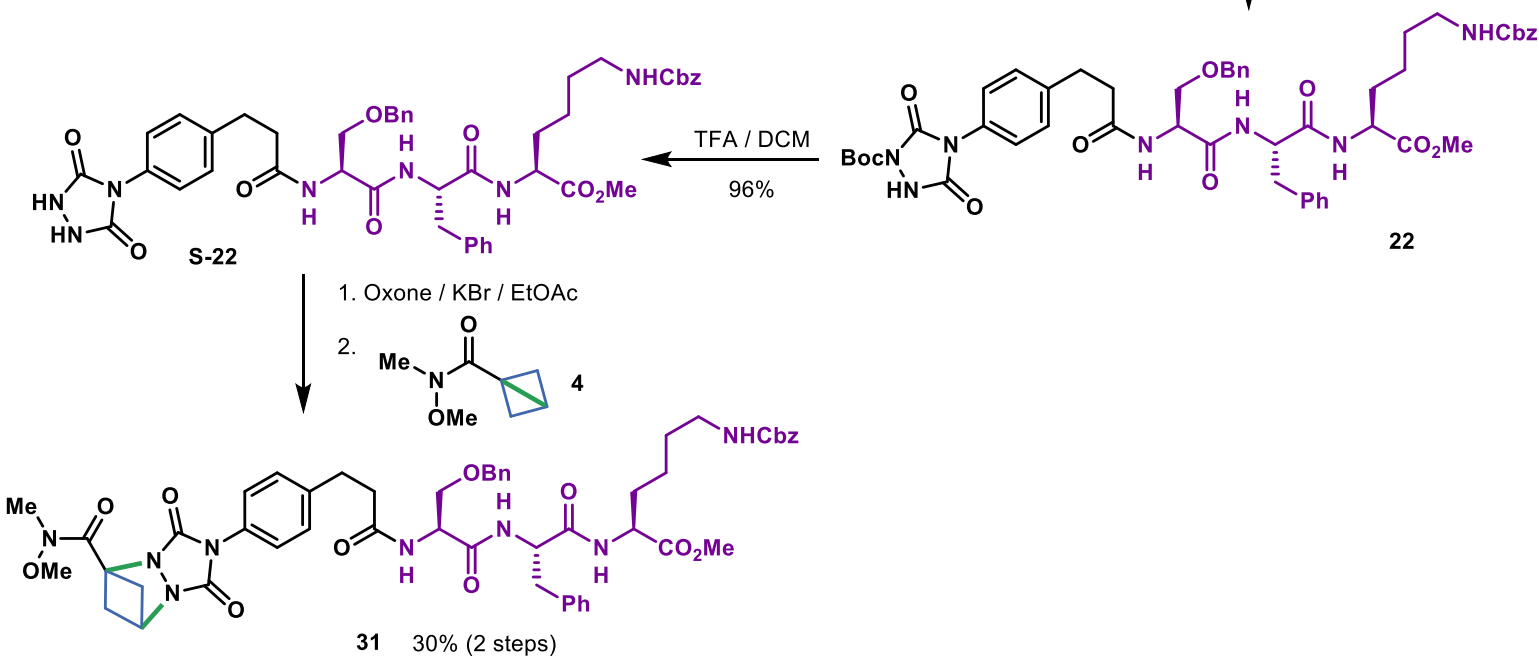




\section{Boc-Phe-Lys(Cbz)-OMe S-19}

A magnetically stirred suspension of Boc-L-phenylalanine $(1.46 \mathrm{~g}, 5.50 \mathrm{mmol})$ in DCM $(20 \mathrm{~mL})$ maintained at $0{ }^{\circ} \mathrm{C}$ (ice-bath) was treated sequentially with DIEA $(5.74 \mathrm{~mL}, 33.0 \mathrm{mmol})$, then T3P ${ }^{\circledR}$ $(4.38 \mathrm{~mL}$ of a $50 \% \mathrm{w} / \mathrm{v}$ solution in EtOAc, $6.88 \mathrm{mmol})$. The reaction was stirred for $0.5 \mathrm{~h}$ and then $N_{\varepsilon}$-Cbz-L-lysine methyl ester hydrochloride was added. After $0.5 \mathrm{~h}$ the cold bath was removed and stirring was maintained at $\mathrm{rt}$ for $18 \mathrm{~h}$ before being diluted into DCM $(50 \mathrm{~mL})$, and then washed sequentially with an ice-cold aqueous solution of potassium hydrogen sulfate $(2 \times 20 \mathrm{~mL}, 0.5 \mathrm{M})$, saturated aqueous solution of sodium hydrogen carbonate $(2 \times 20 \mathrm{~mL})$ and finally brine $(15 \mathrm{~mL})$. The organic layer was dried $\left(\mathrm{Na}_{2} \mathrm{SO}_{4}\right)$ then volatiles removed under reduced pressure to provide a thick oil which was subjected to purification by flash chromatography (silica, 1.5:3.5 v/v EtOAc:DCM). Concentration of the appropriate fractions afforded Boc-Phe-Lys(Cbz)-OMe S-19 (2.14 g, 72\%) as a colourless foam.

$[\alpha]_{D}^{22}-5.2\left(c=1.2, \mathrm{CDCl}_{3}\right)$.

$\mathbf{R}_{f}=0.8(1: 1 v / v$ EtOAc:DCM $)$

${ }^{1}$ H NMR (400 MHz, CDCl $) \delta 7.43-7.13(\mathrm{~m}, 10 \mathrm{H}), 6.82$ (br s, 1H), 5.38 (br s, 1H) 5.26 (br s, 1H), $5.15(\mathrm{~d}, J=12.1 \mathrm{~Hz}, 1 \mathrm{H}), 5.09(\mathrm{~d}, J=12.1 \mathrm{~Hz}, 1 \mathrm{H}), 4.58-4.52(\mathrm{~m}, 1 \mathrm{H}), 4.51-4.43(\mathrm{~m}, 1 \mathrm{H}), 3.71$ (s, 3H), $3.25-3.09$ (m, 3H), $2.97(\mathrm{dd}, J=12.3,7.8 \mathrm{~Hz}, 1 \mathrm{H}), 1.86-1.75(\mathrm{~m}, 1 \mathrm{H}), 1.72-1.62$ (m, $1 \mathrm{H}), 1.57-1.48(\mathrm{~m}, 2 \mathrm{H}), 1.41(\mathrm{~s}, 9 \mathrm{H}), 1.33-1.21(\mathrm{~m}, 2 \mathrm{H})$.

${ }^{13} \mathbf{C}$ NMR (101 MHz, $\left.\mathbf{C D C l}_{3}\right)$ one Ar-C overlapping $\delta 172.3,171.7,156.6,155.7,136.7,129.4$, $128.6,128.6,128.2,128.1,126.9,80.3,66.7,55.8,52.4,52.1,40.6,38.4,31.9,29.3,28.3,22.4$.

LRMS (ESI $\left.{ }^{+}\right): m / z$ (rel. int.) $564(100)[\mathrm{M}+\mathrm{Na}]^{+}$.

HRMS (ESI ${ }^{+}$): calc'd for $\mathrm{C}_{29} \mathrm{H}_{39} \mathrm{~N}_{3} \mathrm{NaO}_{7}[\mathrm{M}+\mathrm{Na}]^{+}:$564.2680, found: 564.2693 .

IR: $\mathrm{V}_{\max }=3325,1686,1659,1518,1249,1165,697 \mathrm{~cm}^{-1}$.

Boc-Ser(OBn)-Phe-Lys(Cbz)-OMe S-20

A magnetically stirred solution of $\mathbf{S - 1 9}(2.00 \mathrm{~g}, 3.69 \mathrm{mmol})$ in DCM $(20 \mathrm{~mL})$ maintained in an icebath, was treated with TFA $(8 \mathrm{~mL})$. After $0.1 \mathrm{~h}$ the mixture was warmed to $\mathrm{rt}$ and stirring continued for $0.75 \mathrm{~h}$ after which time TLC revealed complete consumption of the starting material. The majority of the volatiles were removed with a gentle stream of nitrogen and then the refractory residue subjected to reduced pressure $(\sim 5 \mathrm{mmHg})$ for $5 \mathrm{~h}$ which afforded the deprotected, amine trifluoroacetic acid salt as a crisp foam which was used directly in the amide bond-forming process described directly below. In a separate flask, a magnetically stirred solution of Boc-L-serine(OBn)$\mathrm{OH}(1.09 \mathrm{~g}, 3.69 \mathrm{mmol})$ in DCM $(15 \mathrm{~mL})$, maintained at $0{ }^{\circ} \mathrm{C}$ (ice-bath) was treated sequentially with HOBt (573 mg, $4.24 \mathrm{mmol})$, DIEA (738 $\mu \mathrm{L}, 4.24 \mathrm{mmol})$ then EDC ( $814 \mathrm{mg}, 4.24 \mathrm{mmol})$. The mixture was stirred for $0.5 \mathrm{~h}$ then a mixture of the above formed TFA salt, DIEA $(1.48 \mathrm{~mL}, 8.49 \mathrm{mmol})$ and DCM $(10 \mathrm{~mL})$ was added and stirring maintained for $18 \mathrm{~h}$. The reaction mixture was then diluted with DCM $(50 \mathrm{~mL})$, then washed sequentially with an aqueous solution of potassium hydrogen sulfate $(2 \times 20 \mathrm{~mL}, 1 \mathrm{M})$, a saturated aqueous solution of sodium hydrogen carbonate $(2 \times 20 \mathrm{~mL})$ and brine 
(15 mL). The organic layer was dried $\left(\mathrm{Na}_{2} \mathrm{SO}_{4}\right)$ and then the volatiles were removed under reduced pressure to provide S-20 (2.49 g, 94\%) as a thick foam which was used without further purification.

$[\alpha]_{D}^{22}-8.7(c=1.6, \mathrm{MeOH})$.

${ }^{1}$ H NMR (400 MHz, $\left.\mathbf{C D C l}_{3}\right) \delta 7.39-7.09(\mathrm{~m}, 15 \mathrm{H}), 6.80(\mathrm{~d}, J=6.5 \mathrm{~Hz}, 1 \mathrm{H}), 6.65-6.56(\mathrm{~m}, 1 \mathrm{H})$, $5.34-5.26(\mathrm{~m}, 1 \mathrm{H}), 5.21-5.14(\mathrm{~m}, 1 \mathrm{H}), 5.10(\mathrm{~d}, J=12.3 \mathrm{~Hz}, 1 \mathrm{H}), 5.06(\mathrm{~d}, J=12.2 \mathrm{~Hz}, 1 \mathrm{H}), 4.70$ - $4.61(\mathrm{~m}, 1 \mathrm{H}), 4.52-4.39(\mathrm{~m}, 3 \mathrm{H}), 4.26-4.15(\mathrm{~m}, 1 \mathrm{H}), 3.83-3.75(\mathrm{~m}, 1 \mathrm{H}), 3.69(\mathrm{~s}, 3 \mathrm{H}), 3.53-$ $3.45(\mathrm{~m}, 1 \mathrm{H}), 3.17-3.08(\mathrm{~m}, 3 \mathrm{H}), 3.05(\mathrm{dd}, J=13.9,6.6 \mathrm{~Hz}, 1 \mathrm{H}), 1.80-1.71(\mathrm{~m}, 1 \mathrm{H}), 1.62-1.53$ (m, 1H), $1.49-1.54(\mathrm{~m}, 2 \mathrm{H}), 1.39$ (s, 9H), $1.28-1.16(\mathrm{~m}, 2 \mathrm{H})$.

${ }^{13}$ C NMR (101 MHz, $\left.\mathbf{C D C l}_{3}\right) \delta 172.2,170.4,170.4,156.7,155.7,137.4,136.8,136.4,129.4,128.8$, $128.7,128.6,128.2,128.2,128.1,127.8,127.2,80.7,73.5,69.6,66.7,54.6,54.3,52.5,52.3,40.6$, $37.3,31.7,29.3,28.4,22.4$.

LRMS (ESI $\left.{ }^{+}\right): m / z$ (rel. int.) $719(45)[\mathrm{M}+\mathrm{H}]^{+}, 741(100)[\mathrm{M}+\mathrm{Na}]^{+}$,

HRMS (ESI ${ }^{+}$): calc'd for $\mathrm{C}_{39} \mathrm{H}_{50} \mathrm{~N}_{4} \mathrm{NaO}_{9}[\mathrm{M}+\mathrm{Na}]^{+}:$741.3470, found: 741.3472 .

IR: $\mathrm{V}_{\max }=1701,1650,1526 \mathrm{~cm}^{-1}$.

Ser(OBn)-Phe-Lys(Cbz)-OMe protected urazole adduct 22

A magnetically stirred solution of $\mathbf{S - 2 0}(1.85 \mathrm{~g}, 2.57 \mathrm{mmol})$ in DCM $(10 \mathrm{~mL})$ maintained in an icebath, was treated with TFA $(5 \mathrm{~mL})$. After $0.1 \mathrm{~h}$ the mixture was warmed to $\mathrm{rt}$ and stirring continued for $0.75 \mathrm{~h}$. The majority of the volatiles were removed with a gentle stream of nitrogen and then the residue re-dissolved in DCM (ca. $5 \mathrm{~mL}$ ) and precipitated with diethyl ether $(15 \mathrm{~mL})$. The solution was decanted and the resulting gum was subjected to reduced pressure $(\sim 5 \mathrm{mmHg})$ for $5 \mathrm{~h}$ which afforded the deprotected, amine trifluoroacetic acid salt $\mathbf{S - 2 1}$ as a crisp foam which was used directly in the amide bond-forming process described below.

In a separate flask, a magnetically stirred suspension of carboxylic acid 18 (899 $\mathrm{mg}, 2.57 \mathrm{mmol})$ in DCM $(25 \mathrm{~mL})$, maintained at $0{ }^{\circ} \mathrm{C}$ (ice-bath) was treated sequentially with $\mathrm{HOBt}(382 \mathrm{mg}$, $2.83 \mathrm{mmol})$, DIEA $(491 \mu \mathrm{L}, 2.83 \mathrm{mmol})$ then EDC (542 $\mathrm{mg}, 2.82 \mathrm{mmol})$. After $0.5 \mathrm{~h}$, a subsequent aliquot of DIEA ( $491 \mu \mathrm{L}, 2.83 \mathrm{mmol})$ was added, followed by a solution of amine trifluoroacetic acid salt S-21 formed directly above and DIEA $(491 \mu \mathrm{L}, 2.83 \mathrm{mmol})$ in DCM $(10 \mathrm{~mL})$. The cold bath was removed and stirring was maintained at $\mathrm{rt}$ for $4 \mathrm{~h}$ before being diluted into DCM $(30 \mathrm{~mL})$ and then washed sequentially with an ice-cold aqueous solution of potassium hydrogen sulfate $(2 \times 15 \mathrm{~mL}$, 0.5 M), Dulbecco's phosphate buffered saline phosphate buffer $(2 \times 10 \mathrm{~mL}, \mathrm{pH} 7.4)$ then brine $(15 \mathrm{~mL})$. The organic layer was dried $\left(\mathrm{Na}_{2} \mathrm{SO}_{4}\right)$, concentrated under reduced pressure and the residue so obtained was purified by flash chromatography (silica, 10:0.5:0.1 v/v/v DCM/MeOH/AcOH) to afford $22(1.19 \mathrm{~g}, 49 \%)$ as a white solid.

Data for amine trifluoroacetic acid salt intermediate (H-Ser(OBn)-Phe-Lys(Cbz)-OMe•TFA) S-21

${ }^{1}$ H NMR (400 MHz, DMSO-d $\mathbf{d}_{\mathbf{6}}$ one hydrogen obscured, or overlapping $\delta 8.69(\mathrm{~d}, J=8.2 \mathrm{~Hz}, 1 \mathrm{H})$, $8.54(\mathrm{~d}, J=7.4 \mathrm{~Hz}, 1 \mathrm{H}), 8.21-8.09(\mathrm{~m}, 3 \mathrm{H}), 7.38-7.17$ (m, 15H), $5.06-4.94(\mathrm{~m}, 2 \mathrm{H}), 4.70-4.62$ 
(m, 1H), $4.55-4.47(\mathrm{~m}, 2 \mathrm{H}), 4.24-4.15(\mathrm{~m}, 1 \mathrm{H}), 4.02-3.95(\mathrm{~m}, 1 \mathrm{H}), 3.78(\mathrm{dd}, J=10.6,3.6 \mathrm{~Hz}$, $1 \mathrm{H}), 3.67$ (dd, $J=10.6,6.8 \mathrm{~Hz}, 1 \mathrm{H}), 3.61(\mathrm{~s}, 3 \mathrm{H}), 3.05$ (dd, $J=14.0,4.4 \mathrm{~Hz}, 1 \mathrm{H}), 3.00-2.91$ (m, 2H), $2.80(\mathrm{dd}, J=14.0,9.4 \mathrm{~Hz}, 1 \mathrm{H}), 1.75-1.64(\mathrm{~m}, 1 \mathrm{H}), 1.64-1.51(\mathrm{~m}, 1 \mathrm{H}), 1.43-1.33(\mathrm{~m}, 2 \mathrm{H})$, $1.32-1.19(\mathrm{~m}, 2 \mathrm{H})$.

${ }^{13}$ C NMR (101 MHz, DMSO-d $\boldsymbol{d}_{\mathbf{6}}$ with 5\% $\left.\mathbf{C D C l}_{3}\right) \delta 172.3,170.8,166.3,158.6\left(\mathrm{q},{ }^{2} J_{C-F}=37.4 \mathrm{~Hz}\right)$, $156.2,137.6,137.4,137.3,129.3,128.4,128.3,128.2,128.2,127.8,127.7,127.7,126.5,115.51$ (q, $\left.J_{C-F}=290.0 \mathrm{~Hz}\right), 72.6,68.6,65.2,54.2,52.4,52.2,51.7,40.1,37.6,30.6,29.1,22.7$.

LRMS (ESI $\left.{ }^{+}\right): m / z$ (rel. int.) 619 (100) $[\mathrm{M}+\mathrm{H}]^{+}$.

HRMS (ESI ${ }^{+}$): calc'd for $\mathrm{C}_{34} \mathrm{H}_{43} \mathrm{~N}_{4} \mathrm{O}_{7}[\mathrm{M}+\mathrm{H}]^{+}:$619.3126, found: 619.3136 .

Ser(OBn)-Phe-Lys(Cbz)-OMe protected urazole adduct 22

$\mathbf{R}_{f}=0.3(10: 0.5: 0.1 v / v / v \mathrm{DCM} / \mathrm{MeOH} / \mathrm{AcOH})$

$[\alpha]_{D}^{23}-10.9\left(c=1.1, \mathrm{CDCl}_{3}\right)$.

${ }^{1}$ H NMR (400 MHz, Methanol-d $\left.\boldsymbol{d}_{4}\right)$ NHs not observed $\delta 7.39-7.13(\mathrm{~m}, 19 \mathrm{H}), 5.10-4.99(\mathrm{~m}, 2 \mathrm{H})$, $4.70-4.62(\mathrm{~m}, 1 \mathrm{H}), 4.53-4.49(\mathrm{~m}, 1 \mathrm{H}), 4.48-4.40(\mathrm{~m}, 2 \mathrm{H}), 4.34(\mathrm{dd}, J=9.0,4.9 \mathrm{~Hz}, 1 \mathrm{H}), 3.66(\mathrm{~s}$, $3 \mathrm{H}), 3.60-3.49(\mathrm{~m}, 2 \mathrm{H}), 3.18-2.99(\mathrm{~m}, 3 \mathrm{H}), 2.98-2.85(\mathrm{~m}, 3 \mathrm{H}), 2.58-2.47(\mathrm{~m}, 2 \mathrm{H}), 1.81-1.61$ $(\mathrm{m}, 2 \mathrm{H}), 1.59(\mathrm{~s}, 9 \mathrm{H}) 1.49-1.24(\mathrm{~m}, 4 \mathrm{H})$.

${ }^{13}$ C NMR (101 MHz, Methanol- $\left.\boldsymbol{d}_{4}\right)$ one carbon obscured, or overlapping $\delta 175.0,173.7,173.1$, $171.8,158.8,152.2,148.7,147.4,143.0,139.2,138.4,138.1,130.4,130.3,130.1,129.4,129.4,128.9$, $128.9,128.8,128.7,127.8,127.7,86.9,74.2,70.6,67.3,55.7,54.8,53.7,52.7,41.5,38.5,38.1,32.2$, $32.1,30.3,28.2,23.9$.

LRMS (ESI $\left.{ }^{+}\right): m / z$ (rel. int.) $972(100)[\mathrm{M}+\mathrm{Na}]^{+}$.

HRMS (ESI ${ }^{+}$): calc'd for $\mathrm{C}_{50} \mathrm{H}_{59} \mathrm{~N}_{7} \mathrm{NaO}_{12}[\mathrm{M}+\mathrm{H}]^{+}$: 972.4114 , found: 972.4099 .

Ser(OBn)-Phe-Lys(Cbz)-OMe urazole adduct $\mathbf{S - 2 2}$

A magnetically stirred solution of $22(545 \mathrm{mg}, 2.57 \mathrm{mmol})$ in DCM $(10 \mathrm{~mL})$ maintained in an icebath, was treated with TFA $(3.5 \mathrm{~mL})$. After $0.1 \mathrm{~h}$ the mixture was warmed to $\mathrm{rt}$ and stirring continued for $0.75 \mathrm{~h}$. The majority of the volatiles were removed with a gentle stream of nitrogen and then the residue was re-dissolved in DCM (ca. $5 \mathrm{~mL}$ ) and precipitated with 1:1 v/v diethyl ether/pet. spirit $(15 \mathrm{~mL})$. The solution was decanted from the sticky gum and the precipitation process was repeated and the resulting gum was subjected to reduced pressure $(\sim 0.8 \mathrm{mmHg})$ for $18 \mathrm{~h}$ which afforded $\mathbf{S - 2 2}$ (469 $\mathrm{mg}, 96 \%$ ) as a crisp foam used without further purification.

$[\alpha]_{D}^{22}-15.4(c=1.0, \mathrm{MeOH})$.

${ }^{1}$ H NMR (700 MHz, Methanol- $\boldsymbol{d}_{\mathbf{4}}$ ) 4 NHs not observed $\delta 8.18(\mathrm{~d}, J=7.8 \mathrm{~Hz}, \mathrm{NH}), 8.05(\mathrm{~d}, J=7.4$ $\mathrm{Hz}, 0.3 \mathrm{NH}), 7.94(\mathrm{~d}, J=7.9 \mathrm{~Hz}, 0.6 \mathrm{NH}), 7.33-7.15$ (m, 19H), $5.06-5.02(\mathrm{~m}, 2 \mathrm{H}), 4.68-4.64(\mathrm{~m}$, 
1H), $4.52-4.49(\mathrm{~m}, 1 \mathrm{H}), 4.47(\mathrm{~d}, J=12.0 \mathrm{~Hz}, 1 \mathrm{H}), 4.44(\mathrm{~d}, J=12.0 \mathrm{~Hz}, 1 \mathrm{H}), 4.36-4.33(\mathrm{~m}, 1 \mathrm{H})$, $3.66(\mathrm{~s}, 3 \mathrm{H}), 3.59(\mathrm{dd}, J=9.9,5.7 \mathrm{~Hz}, 1 \mathrm{H}), 3.54(\mathrm{dd}, J=9.9,5.3 \mathrm{~Hz}, 1 \mathrm{H}), 3.14(\mathrm{dd}, J=14.0,5.8 \mathrm{~Hz}$, $1 \mathrm{H}), 3.10-3.03(\mathrm{~m}, 2 \mathrm{H}), 2.95(\mathrm{dd}, J=13.9,8.1 \mathrm{~Hz}, 1 \mathrm{H}), 2.92-2.86(\mathrm{~m}, 2 \mathrm{H}), 2.52(\mathrm{t}, J=7.8 \mathrm{~Hz}$, $2 \mathrm{H}), 1.81-1.75(\mathrm{~m}, 1 \mathrm{H}), 1.67-1.61(\mathrm{~m}, 1 \mathrm{H}), 1.49-1.40(\mathrm{~m}, 2 \mathrm{H}), 1.35-1.28(\mathrm{~m}, 2 \mathrm{H})$.

${ }^{13}$ C NMR (176 MHz, Methanol-d $\mathbf{d}_{4}$ ) mixture of rotamers, 2 Ar-C peaks overlapping $\delta$ 175.1, 173.7(3) \& 173.7(1), $173.2 \& 173.1,171.9,158.9,155.8,142.5,139.2,138.4,138.1,130.9,130.4,130.1$, $129.5,129.4,128.9(3), 128.9(0), 128.8,127.8,127.4,74.2,70.5,67.3,55.7(5) \& 55.7(1), 53.8 \&$ $53.7,52.7,41.5,38.5,38.2,32.2,32.1(1) \& 32.0(8), 30.3,24.2,23.9$.

LRMS (ESI $\left.{ }^{+}\right): m / z$ (rel. int.) $872(100)[\mathrm{M}+\mathrm{Na}]^{+}$.

HRMS (ESI'): calc'd for $\mathrm{C}_{45} \mathrm{H}_{50} \mathrm{~N}_{7} \mathrm{O}_{10}[\mathrm{M}-\mathrm{H}]^{-}: 848.3625$, found: 848.3625

\section{Ser(OBn)-Phe-Lys(Cbz)-OMe TAD cycloadduct $\mathbf{3 1}$}

A magnetically and vigorously-stirred suspension of $\mathbf{S - 2 2}(170 \mathrm{mg}, 0.20 \mathrm{mmol})$ in DCM $(10 \mathrm{~mL})$ maintained at $\mathrm{rt}$, was charged sequentially with powdered $\mathrm{KBr}(7 \mathrm{mg}, 50 \mu \mathrm{mol})$, Oxone $(141 \mathrm{mg}$, $0.23 \mathrm{mmol})$ then water $(100 \mu \mathrm{L})$. The suspension was stirred vigorously and after $0.5 \mathrm{~h}$, the red mixture was filtered through a $0.45 \mu \mathrm{m}$ nylon syringe filter and the filtrate collected. The volatiles were removed with a gentle stream of nitrogen to afford a red solid which was immediately dissolved in ethyl acetate $(10 \mathrm{~mL})$ and treated with a solution of $N$-methoxy- $N$-methylbicyclo[1.1.0]butane-1carboxamide (4) $(56 \mathrm{mg}, 0.40 \mathrm{mmol})$ in ether $(3 \mathrm{~mL})$. After stirring for $1.5 \mathrm{~h}$ the colourless mixture was concentrated under reduced pressure with a gentle stream of nitrogen and the ensuing residue was subjected to purification by flash chromatography (silica, 10:1 v/v DCM/MeOH). Concentration of the appropriate fractions afforded $\mathbf{3 1}(59 \mathrm{mg}, 30 \%)$ as a colourless foam.

$[\boldsymbol{\alpha}]_{\boldsymbol{D}}^{\mathbf{2 3}}-13.3(c=1.0, \mathrm{MeOH})$.

$\mathbf{R}_{f}=0.5(10: 1 v / v \mathrm{DCM} / \mathrm{MeOH})$.

${ }^{1}$ H NMR (700 MHz, Methanol- $\left.\boldsymbol{d}_{4}\right) 4$ NHs not observed $\delta 7.33-7.14(\mathrm{~m}, 19 \mathrm{H}), 5.06-5.02(\mathrm{~m}, 2 \mathrm{H})$, 4.75 (app. t, $J=2.0 \mathrm{~Hz}, 1 \mathrm{H}$ ), 4.65 (dd, $J=8.1,5.8 \mathrm{~Hz}, 1 \mathrm{H}$ ), 4.49 (app. t, $J=5.5 \mathrm{~Hz}, 1 \mathrm{H}$ ), $4.47-4.42$ $(\mathrm{m}, 2 \mathrm{H}), 4.34(\mathrm{dd}, J=9.1,5.0 \mathrm{~Hz}, 1 \mathrm{H}), 3.83(\mathrm{~s}, 3 \mathrm{H}), 3.67(\mathrm{~s}, 3 \mathrm{H}), 3.57(\mathrm{dd}, J=9.9,5.7 \mathrm{~Hz}, 1 \mathrm{H}), 3.52$ $(\mathrm{dd}, J=9.9,5.3 \mathrm{~Hz}, 1 \mathrm{H}), 3.28(\mathrm{~s}, 3 \mathrm{H}), 3.13(\mathrm{dd}, J=14.1,5.8 \mathrm{~Hz}, 1 \mathrm{H}), 3.11-3.03(\mathrm{~m}, 2 \mathrm{H}), 2.94(\mathrm{dd}$, $J=14.1,8.1 \mathrm{~Hz}, 1 \mathrm{H}), 2.92-2.89(\mathrm{~m}, 2 \mathrm{H}), 2.65-2.60(\mathrm{~m}, 2 \mathrm{H}), 2.56-2.50(\mathrm{~m}, 2 \mathrm{H}), 2.19-2.14(\mathrm{~m}$, $2 \mathrm{H}), 1.81-1.74(\mathrm{~m}, 1 \mathrm{H}), 1.67-1.60(\mathrm{~m}, 1 \mathrm{H}), 1.49-1.39(\mathrm{~m}, 2 \mathrm{H}), 1.36-1.26(\mathrm{~m}, 2 \mathrm{H})$.

${ }^{13}$ C NMR (176 MHz, Methanol- $\left.d_{4}\right) \delta 175.0,173.7,173.1,171.8,166.1,161.0,160.4,158.9,143.2$, $139.2,138.5,138.1,130.7,130.4,130.3,129.5,129.4(5), 129.4(2), 128.9(33), 128.9(25), 128.8$, $127.8,127.1,74.7,74.2,70.6,67.3,62.7,61.0,55.7,54.8,53.7,52.7,49.4,44.2,41.5,38.5,38.1$, $32.9,32.2,32.1,30.3,23.9$.

LRMS (ESI $\left.{ }^{+}\right): m / z$ (rel. int.) $1011(100)[\mathrm{M}+\mathrm{Na}]^{+}$.

HRMS (ESI ${ }^{+}$): calc'd for $\mathrm{C}_{52} \mathrm{H}_{60} \mathrm{~N}_{8} \mathrm{NaO}_{12}[\mathrm{M}+\mathrm{Na}]^{+}:$1011.4223, found: 1011.4235

IR: $V_{\max }=1723,1635,1515,1395 \mathrm{~cm}^{-1}$. 

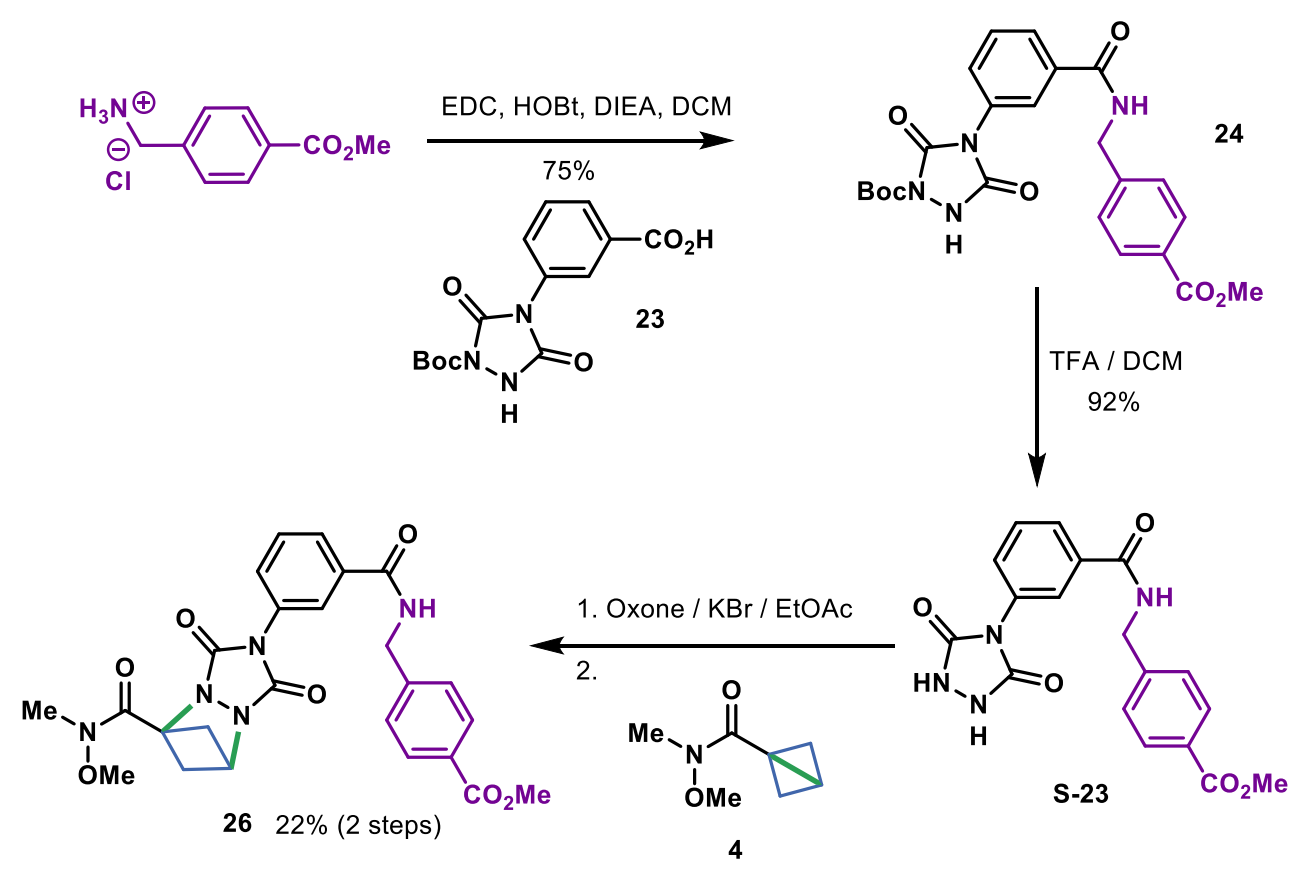

\section{Protected urazole adduct $\mathbf{2 4}$}

A magnetically stirred suspension of $23(266 \mathrm{mg}, 0.83 \mathrm{mmol})$ in DCM $(10 \mathrm{~mL})$, maintained at $0{ }^{\circ} \mathrm{C}$ (ice-bath) was treated sequentially with $\operatorname{HOBt}(123 \mathrm{mg}, 0.91 \mathrm{mmol})$, DIEA $(191 \mu \mathrm{L}, 0.91 \mathrm{mmol})$ then EDC $(175 \mathrm{mg}, 0.91 \mathrm{mmol})$. After $0.5 \mathrm{~h}$, a subsequent aliquot of DIEA $(191 \mu \mathrm{L}, 0.91 \mathrm{mmol})$ was added, followed by methyl 4-(aminomethyl)benzoate hydrochloride $(167 \mathrm{mg}, 0.83 \mathrm{mmol}$ ) and then a final aliquot of DIEA $(191 \mu \mathrm{L}, 1.10 \mathrm{mmol})$. The cold bath was removed and stirring was maintained at $\mathrm{rt}$ for $18 \mathrm{~h}$ before being diluted into DCM $(30 \mathrm{~mL})$ and then washed sequentially with an ice-cold aqueous solution of potassium hydrogen sulfate $(2 \times 15 \mathrm{~mL}, 0.5 \mathrm{M})$, Dulbecco's phosphate buffered saline $(2 \times 10 \mathrm{~mL}, \mathrm{pH} 7.4)$ then brine $(15 \mathrm{~mL})$. The organic layer was dried $\left(\mathrm{Na}_{2} \mathrm{SO}_{4}\right)$, concentrated under reduced pressure and the residue so obtained was purified by two sequential flash columns: column 1, silica, 30:1:0.05 v/v/v DCM:MeOH:AcOH; column 2, 7:1.5:1.5 v/v/v DCM:EtOAc:Acetone to afford $24(292 \mathrm{mg}, 75 \%)$ as a colourless foam.

$\mathbf{R}_{\boldsymbol{f}}=0.3(30: 1: 0.05 v / v / v$ DCM:MeOH:AcOH$)$

${ }^{1}$ H NMR (400 MHz, CDCl $\left.\mathbf{3}\right) \delta 9.86(\mathrm{br} \mathrm{s}, 1 \mathrm{H}), 7.92-7.87(\mathrm{~m}, 3 \mathrm{H}), 7.85-7.81(\mathrm{~m}, 1 \mathrm{H}), 7.52-7.45$ (m, 2H), $7.45-7.40(\mathrm{~m}, 1 \mathrm{H}), 7.33-7.28(\mathrm{~m}, 2 \mathrm{H}), 4.56(\mathrm{~d}, J=5.8 \mathrm{~Hz}, 2 \mathrm{H}), 3.85(\mathrm{~s}, 3 \mathrm{H}), 1.49$ (s, $9 \mathrm{H})$.

${ }^{13}$ C NMR (101 MHz, CDCl $) \delta$ 167.0, 166.6, 150.0, 146.1, 145.5, 143.5, 135.3, 130.8, 129.9, 129.6, $129.2,129.0,127.8,127.7,124.8,86.9,52.2,43.8,27.9$.

LRMS (ESI $\left.{ }^{+}\right): m / z$ (rel. int.) $491(100)[\mathrm{M}+\mathrm{Na}]^{+}$.

HRMS (ESI ${ }^{+}$): calc'd for $\mathrm{C}_{23} \mathrm{H}_{24} \mathrm{~N}_{4} \mathrm{NaO}_{7}[\mathrm{M}+\mathrm{Na}]^{+}: 491.1537$, found: 491.1534 . 


\section{Urazole adduct $\mathbf{S - 2 3}$}

A magnetically stirred solution of $\mathbf{2 4}(165 \mathrm{mg}, 6.84 \mathrm{mmol})$ in DCM $(15 \mathrm{~mL})$ maintained in an icebath, was treated with TFA $(5 \mathrm{~mL})$. After $0.1 \mathrm{~h}$ the mixture was warmed to $\mathrm{rt}$ and stirring continued for $0.75 \mathrm{~h}$ after which time TLC revealed complete consumption of the starting material. The majority of the volatiles were removed with a gentle stream of nitrogen and then the residue re-dissolved in DCM (ca. $1 \mathrm{~mL})$ and precipitated with diethyl ether/pet. spirit $(1: 1 v / v, 5 \mathrm{~mL})$. Water $(5 \mathrm{~mL})$ was added and the mixture was then sonicated for 2 minutes and then the water was removed by freezedrying (18 h, $0.5 \mathrm{mmHg}$ ) to afford $\mathbf{S - 2 3}(155 \mathrm{mg}, 92 \%)$ as an amorphous white powder and used without further purification.

${ }^{1}$ H NMR (700 MHz, DMSO-d 6 ) $\delta 10.57(\mathrm{~s}, 2 \mathrm{H}), 9.22(\mathrm{t}, J=6.0 \mathrm{~Hz}, 1 \mathrm{H}), 8.00-7.99(\mathrm{~m}, 1 \mathrm{H}), 7.95$ -7.92 (m, 3H), $7.65-7.64$ (m, 1H), 7.61 (app. t, $J=7.8 \mathrm{~Hz}, 1 \mathrm{H}), 7.48-7.46$ (m, 2H), 4.57 (d, $J=$ $5.9 \mathrm{~Hz}, 2 \mathrm{H}), 3.85(\mathrm{~s}, 3 \mathrm{H})$.

${ }^{13}$ C NMR (176 MHz, DMSO-d $\mathbf{d}_{\mathbf{6}}$ ) one Ar-C signal obscured or overlapping $\delta=166.1,165.4,153.1$, $145.2,134.8,132.1,129.3,129.0,128.2,127.4,126.3,125.1,52.1,42.5$.

LRMS (ESI $\left.{ }^{-}\right): m / z$ (rel. int.) 367 (100) [M-H] $]^{-}$.

HRMS (ESI-): calc'd for $\mathrm{C}_{18} \mathrm{H}_{15} \mathrm{~N}^{-} \mathrm{O}_{5}[\mathrm{M}-\mathrm{H}]^{-} .367 .1048$, found: 367.1049 .

MP: $214-218{ }^{\circ} \mathrm{C}$.

\section{TAD cycloadduct $\mathbf{2 6}$}

A magnetically and vigorously-stirred suspension of $\mathbf{S - 2 3}(117 \mathrm{mg}, 0.32 \mathrm{mmol})$ in DCM $(10 \mathrm{~mL})$ maintained at $\mathrm{rt}$, was charged sequentially with powdered $\mathrm{KBr}(10 \mathrm{mg}, 84 \mu \mathrm{mol})$, Oxone $(264 \mathrm{mg}$, $0.43 \mathrm{mmol})$ then water $(100 \mu \mathrm{L})$. The suspension was stirred vigorously and after $1 \mathrm{~h}$, the red mixture was filtered through a $0.45 \mu \mathrm{m}$ nylon syringe filter and the filtrate collected. The volatiles were removed with a gentle stream of nitrogen to afford a red solid which was immediately dissolved in THF $(5 \mathrm{~mL})$ and treated with a solution of $N$-methoxy- $N$-methylbicyclo[1.1.0]butane-1-carboxamide (4) $(90 \mathrm{mg}, 0.64 \mathrm{mmol})$ in ether $(1.5 \mathrm{~mL})$. After stirring for $1 \mathrm{~h}$ the colourless mixture was concentrated under reduced pressure with a gentle stream of nitrogen and the ensuing residue was subjected to purification by flash chromatography (silica, 7:1.5:1.5 v/v/v DCM/EtOAc/Acetone). Concentration of the appropriate fractions afforded 26 (35 mg, 22\%) as a colourless foam.

$\mathbf{R}_{f}=0.4(7: 1.5: 1.5 v / v / v$ DCM/EtOAc/Acetone $)$

${ }^{1} \mathbf{H}$ NMR (700 MHz, CDCl $\left.)_{3}\right) \delta .98-7.96$ (m, 2H), 7.93 (app. t, $\left.J=1.7 \mathrm{~Hz}, 1 \mathrm{H}\right), 7.87$ (app. dt, $J=$ 7.9, 1.3 Hz, 1H), 7.64 (app. d, $J=7.9 \mathrm{~Hz}, 1 \mathrm{H}$ ), 7.52 (app. t, $J=7.9 \mathrm{~Hz}, 1 \mathrm{H}$ ), $7.39-7.37$ (m, 2H), 6.89 (app. t, $J=5.9 \mathrm{~Hz}, 1 \mathrm{H}$ ), 4.74 (app. t, $J=2.0 \mathrm{~Hz}, 1 \mathrm{H}), 4.65$ (d, $J=5.9 \mathrm{~Hz}, 2 \mathrm{H}$ ), 3.89 (s, 3H), 3.81 (s, 3H), 3.27 (s, 3H), $2.56-2.49(\mathrm{~m}, 2 \mathrm{H}), 2.23-2.16(\mathrm{~m}, 2 \mathrm{H})$.

${ }^{13}$ C NMR (176 MHz, CDCl $) \delta 166.9,166.2,164.1,159.0,158.5,143.4,135.5,131.7,130.1,129.7$, $129.5,128.2,127.8,127.7,123.5,73.6,62.3,59.7,52.2,43.9,43.6,32.7$.

LRMS (ESI $\left.{ }^{+}\right): m / z$ (rel. int.) $530(100)[\mathrm{M}+\mathrm{Na}]^{+}$.

HRMS (ESI ${ }^{+}$): calc'd for $\mathrm{C}_{25} \mathrm{H}_{25} \mathrm{~N}_{5} \mathrm{NaO}_{7}[\mathrm{M}+\mathrm{Na}]^{+}$. 530.1646, found: 530.1656. 


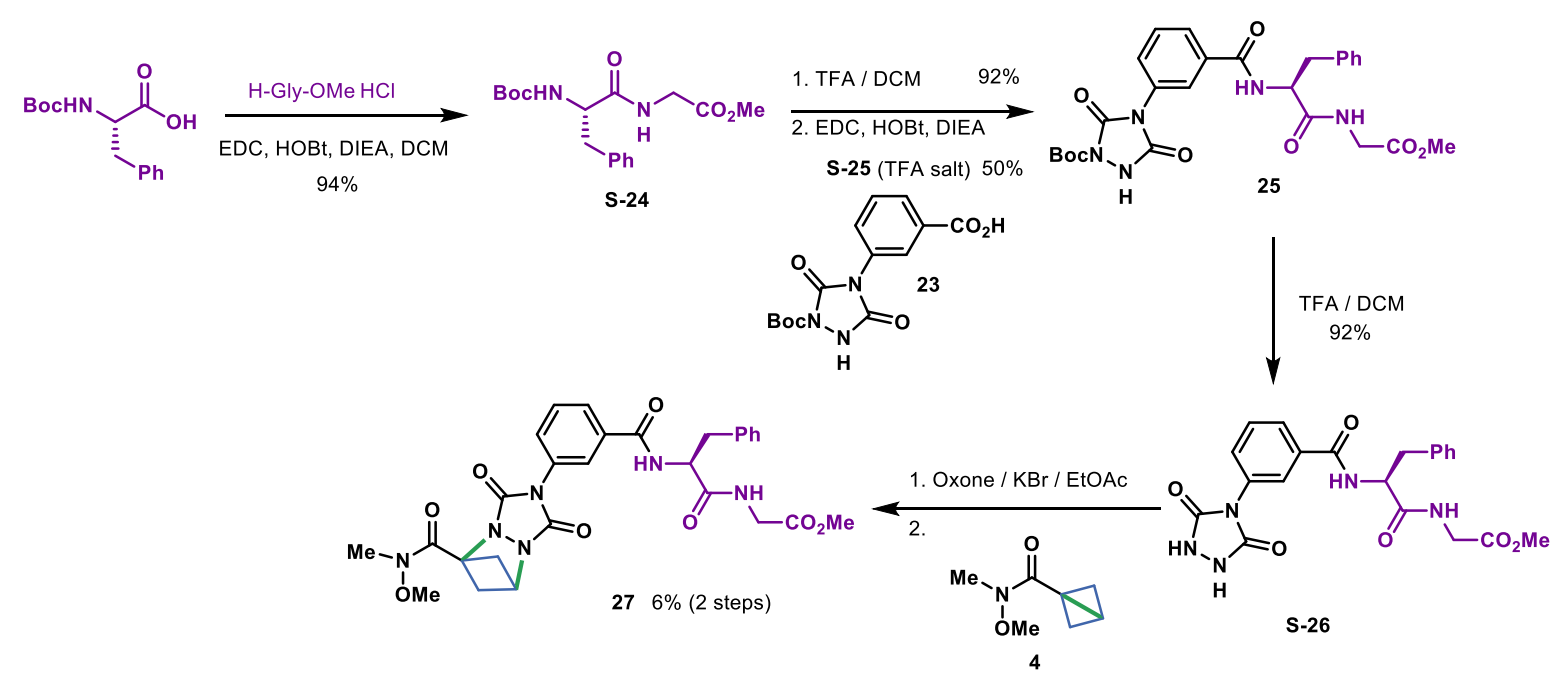

\section{Boc-Phe-Gly-OMe S-24}

A magnetically stirred suspension of Boc- $L$-phenylalanine $(2.00 \mathrm{~g}, 7.50 \mathrm{mmol})$ in DCM $(25 \mathrm{~mL})$, maintained at $0{ }^{\circ} \mathrm{C}$ (ice-bath) was treated sequentially with $\mathrm{HOBt}(1.11 \mathrm{~g}, 8.22 \mathrm{mmol})$, DIEA (3.26 mL, $18.8 \mathrm{mmol})$ then EDC (1.58 g, $8.22 \mathrm{mmol})$. After $0.5 \mathrm{~h}$, glycine methyl ester hydrochloride $(0.95 \mathrm{~g}, 7.54 \mathrm{mmol})$. The cold bath was removed and stirring was maintained at $\mathrm{rt}$ for $4 \mathrm{~h}$ before being diluted into DCM $(50 \mathrm{~mL})$ and then washed sequentially with potassium hydrogen sulfate $(2 \times 15 \mathrm{~mL}$, $1 \mathrm{M})$, saturated aqueous sodium bicarbonate $(2 \times 15 \mathrm{~mL})$ then brine $(15 \mathrm{~mL})$. The organic layer was dried $\left(\mathrm{Na}_{2} \mathrm{SO}_{4}\right)$, concentrated under reduced pressure and the residue so obtained was purified by flash chromatography (silica, 1:10 v/v MeOH/DCM) to afford S-24 (2.36 mg, 94\%) as a colourless foam and used without further purification. Spectral data were consistent with those reported. ${ }^{10 a}$

${ }^{1} \mathbf{H}$ NMR (400 MHz, $\left.\mathbf{C D C l}_{3}\right) \delta 7.34-7.15(\mathrm{~m}, 5 \mathrm{H}), 6.41-6.34(\mathrm{~m}, 1 \mathrm{H}), 5.02-4.91(\mathrm{~m}, 1 \mathrm{H}), 4.45$ $-4.34(\mathrm{~m}, 1 \mathrm{H}), 4.04(\mathrm{dd}, J=18.3,5.4 \mathrm{~Hz}, 1 \mathrm{H}), 3.93(\mathrm{dd}, J=18.3,5.0 \mathrm{~Hz}, 1 \mathrm{H}), 3.73(\mathrm{~s}, 3 \mathrm{H}), 3.16-$ $3.04(\mathrm{~m}, 2 \mathrm{H}), 1.40(\mathrm{~s}, 9 \mathrm{H})$.

LRMS (ESI $\left.{ }^{+}\right): m / z$ (rel. int.) $359(100)[\mathrm{M}+\mathrm{Na}]^{+}$.

HRMS (ESI ${ }^{+}$): calc'd for $\mathrm{C}_{17} \mathrm{H}_{24} \mathrm{~N}_{2} \mathrm{NaO}_{5}[\mathrm{M}+\mathrm{Na}]^{+}: 359.1577$, found: 359.1586

\section{H-Phe-Gly-OMe•TFA S-25}

A magnetically stirred solution of $\mathbf{S - 2 4}(2.30 \mathrm{~g}, 6.84 \mathrm{mmol})$ in DCM $(15 \mathrm{~mL})$ maintained in an icebath, was treated with TFA $(5 \mathrm{~mL})$. After $0.1 \mathrm{~h}$ the mixture was warmed to $\mathrm{rt}$ and stirring continued for $0.75 \mathrm{~h}$ after which time TLC revealed complete consumption of the starting material. The majority of the volatiles were removed with a gentle stream of nitrogen and then the residue re-dissolved in DCM (ca. $5 \mathrm{~mL}$ ) and precipitated with diethyl ether $(15 \mathrm{~mL})$. The resulting, thick oil was then subjected to reduced pressure $(\sim 5 \mathrm{mmHg})$ for $5 \mathrm{~h}$ which afforded the deprotected amine trifluoroacetic acid salt of Phe-Gly-OMe S-25 (2.20 g, 92\%) as a colourless oil which was used without further purification. 
${ }^{1}$ H NMR (400 MHz, DMSO-d $\left.d_{6}\right) \delta 9.01(\mathrm{t}, J=5.8 \mathrm{~Hz}, 1 \mathrm{H}), 8.23$ (br s, 3H), $7.41-7.20(\mathrm{~m}, 5 \mathrm{H}), 4.10$ (m, 1H), $4.01-3.88(\mathrm{~m}, 2 \mathrm{H}), 3.65(\mathrm{~s}, 3 \mathrm{H}), 3.13(\mathrm{dd}, J=14.1,5.7 \mathrm{~Hz}, 1 \mathrm{H}), 2.98(\mathrm{dd}, J=14.1,7.7 \mathrm{~Hz}$, $1 \mathrm{H})$.

${ }^{13}$ C NMR (101 MHz, DMSO-d $\left.\boldsymbol{d}_{6}\right) \delta=169.8,168.7,158.6$ (q, $\left.{ }^{2} J_{C-F}=35.8 \mathrm{~Hz}\right), 134.9,129.6,128.6$, 127.2, $115.7\left(\mathrm{q}, J_{C-F}=293 \mathrm{~Hz}\right) 53.4,51.9,40.7,37.0$.

LRMS (ESI $\left.{ }^{+}\right): m / z$ (rel. int.) $237(100)[\mathrm{M}+\mathrm{H}]^{+}$.

HRMS (ESI ${ }^{+}$): calc'd for $\mathrm{C}_{12} \mathrm{H}_{17} \mathrm{~N}_{2} \mathrm{O}_{3}[\mathrm{M}+\mathrm{H}]^{+}:$237.1234, found: 237.1230 .

\section{Phe-Gly protected urazole adduct $\mathbf{2 5}$}

A magnetically stirred suspension of $23(480 \mathrm{mg}, 1.50 \mathrm{mmol})$ in DCM $(15 \mathrm{~mL})$, maintained at $0{ }^{\circ} \mathrm{C}$ (ice-bath) was treated sequentially with $\mathrm{HOBt}(221 \mathrm{mg}, 1.64 \mathrm{mmol})$, DIEA $(285 \mu \mathrm{L}, 1.64 \mathrm{mmol})$ then EDC (315 mg, $1.64 \mathrm{mmol})$. After $0.5 \mathrm{~h}$, a subsequent aliquot of DIEA ( $285 \mu \mathrm{L}, 1.64 \mathrm{mmol})$ was added, followed by H-Phe-Gly-OMe trifluoroacetic acid salt (S-25) $(524 \mathrm{mg}, 1.49 \mathrm{mmol})$ and then a final aliquot of DIEA ( $285 \mu \mathrm{L}, 1.64 \mathrm{mmol})$. The cold bath was removed and stirring was maintained at $\mathrm{rt}$ for $18 \mathrm{~h}$ before being diluted into DCM $(30 \mathrm{~mL})$ and then washed sequentially with, an ice-cold aqueous solution of potassium hydrogen sulfate $(2 \times 15 \mathrm{~mL}, 0.5 \mathrm{M})$, Dulbecco's phosphate buffered saline $(2 \times 10 \mathrm{~mL}, \mathrm{pH} 7.4)$ then brine $(15 \mathrm{~mL})$. The organic layer was dried $\left(\mathrm{Na}_{2} \mathrm{SO}_{4}\right)$, concentrated under reduced pressure and the residue so obtained was purified by flash chromatography (silica, 10:1 $v / v$ DCM:MeOH) to afford $\mathbf{2 5}(405 \mathrm{mg}, 50 \%)$ as a colourless foam.

$\mathbf{R}_{f}=0.5(10: 1 v / v$ DCM:MeOH$)$

$[\alpha]_{D}^{22}-24.9(c=1.0, \mathrm{MeOH})$.

${ }^{1} \mathbf{H}$ NMR (40 MHz, CDCl 3$) \delta 10.15$ (br, s, 1H), $7.94(\mathrm{~s}, 1 \mathrm{H}), 7.80-7.73(\mathrm{~m}, 2 \mathrm{H}), 7.58-7.53(\mathrm{~m}$, $1 \mathrm{H}), 7.44-7.40$ (m, 1H), $7.33-7.14$ (m, 6H), 5.03 (app. q, $J=7.6 \mathrm{~Hz}, 1 \mathrm{H}), 4.02$ (dd, $J=18.0,5.6$ $\mathrm{Hz}, 1 \mathrm{H}), 3.95$ (dd, $J=18.0,5.5 \mathrm{~Hz}, 1 \mathrm{H}), 3.67$ (s, 3H), 3.29 (dd, $J=13.9,6.6 \mathrm{~Hz}, 1 \mathrm{H}), 3.17$ (dd, $J=$ $13.9,7.9 \mathrm{~Hz}, 1 \mathrm{H}), 1.56(\mathrm{~s}, 9 \mathrm{H})$.

${ }^{13}$ C NMR (101 MHz, CDCl $) \delta 172.1,170.1,166.5,150.2,146.2,145.8,136.9,134.7,130.9,129.4$, $129.4,129.3,128.7,127.7,127.0,125.2,86.7,55.2,52.4,41.4,37.8,28.0$.

LRMS (ESI $\left.{ }^{+}\right): m / z$ (rel. int.) $562(100)[\mathrm{M}+\mathrm{Na}]^{+}$.

HRMS (ESI ${ }^{+}$): calc'd for $\mathrm{C}_{26} \mathrm{H}_{29} \mathrm{~N}_{5} \mathrm{NaO}_{8}[\mathrm{M}+\mathrm{Na}]^{+}:$562.1908, found: 562.1904 .

HRMS (ESI'): calc'd for $\mathrm{C}_{26} \mathrm{H}_{28} \mathrm{~N}_{5} \mathrm{O}_{8}[\mathrm{M}-\mathrm{H}]^{-}:$538.1943, found: 538.1949

\section{Phe-Gly urazole adduct $\mathbf{S - 2 6}$}

A magnetically stirred solution of $25(195 \mathrm{mg}, 0.36 \mathrm{mmol})$ in DCM $(15 \mathrm{~mL})$ maintained in an icebath, was treated with TFA $(5 \mathrm{~mL})$. After $0.1 \mathrm{~h}$ the mixture was warmed to $\mathrm{rt}$ and stirring continued for $0.75 \mathrm{~h}$. The majority of the volatiles were removed with a gentle stream of nitrogen and then the residue re-dissolved in DCM (ca. $5 \mathrm{~mL}$ ) and volatiles removed. Water $(5 \mathrm{~mL})$ was added and the 
mixture was then sonicated for 2 minutes and then the water was removed by freeze-drying ( $18 \mathrm{~h}$, $0.5 \mathrm{mmHg}$ ) to afford $\mathbf{S - 2 6}(155 \mathrm{mg}, 92 \%)$ as an amorphous white powder.

$[\alpha]_{D}^{21}-46.0(c=1.0, \mathrm{MeOH})$.

${ }^{1}$ H NMR (400 MHz, Methanol-d 4 ) 4 NHs not observed $\delta 7.83(\mathrm{t}, J=1.9 \mathrm{~Hz}, 1 \mathrm{H}), 7.74(\mathrm{dt}, J=7.6$, $1.1 \mathrm{~Hz}, 1 \mathrm{H}$ ), $7.65-7.62$ (m, 1H), 7.54 (app. t, $J=7.9 \mathrm{~Hz}, 1 \mathrm{H}), 7.33-7.23$ (m, 4H), $7.20-7.15$ (m, $1 \mathrm{H}), 4.93-4.89(\mathrm{~m}, 1 \mathrm{H}), 3.97-3.94(\mathrm{~m}, 2 \mathrm{H}), 3.71(\mathrm{~s}, 3 \mathrm{H}), 3.35-3.29(\mathrm{~m}, 1 \mathrm{H}), 3.04(\mathrm{dd}, J=13.9$, 9.7 Hz, 1H).

${ }^{13}$ C NMR (101 MHz, Methanol-d $\left.\boldsymbol{d}_{4}\right) \delta 174.2,171.6,169.1,155.3,138.7,136.4,133.1,130.4$, 130.3(4), 130.3(2), 129.5, 128.2, 127.7, 126.2, 56.5, 52.6, 41.9, 38.7.

LRMS (ESI-): $m / z$ (rel. int.) $438(100)[\mathrm{M}-\mathrm{H}]^{-}$.

HRMS (ESI'): calc'd for $\mathrm{C}_{21} \mathrm{H}_{20} \mathrm{~N}_{5} \mathrm{O}_{6}[\mathrm{M}-\mathrm{H}]^{-}: 438.1419$, found: 438.1415

IR: $\mathrm{V}_{\max }=1695,1644 \mathrm{~cm}^{-1}$.

\section{Phe-Gly TAD cycloadduct 27}

A magnetically and vigorously-stirred suspension of $\mathbf{S - 2 6}(138 \mathrm{mg}, 0.31 \mathrm{mmol})$ in DCM $(10 \mathrm{~mL})$ maintained at $\mathrm{rt}$, was charged sequentially with powdered $\mathrm{KBr}(11 \mathrm{mg}, 84 \mu \mathrm{mol})$, Oxone $(236 \mathrm{mg}$, $0.38 \mathrm{mmol})$ then water $(100 \mu \mathrm{L})$. The suspension was stirred vigorously and after $1 \mathrm{~h}$, the red-coloured mixture was filtered through a $0.45 \mu \mathrm{m}$ nylon syringe filter and the filtrate collected. The volatiles were removed with a gentle stream of nitrogen to afford a red solid which was immediately dissolved in ethyl acetate $(10 \mathrm{~mL})$ and treated with a solution of $N$-methoxy- $N$-methylbicyclo[1.1.0]butane-1carboxamide (4) $(90 \mathrm{mg}, 0.64 \mathrm{mmol})$ in ether $(2 \mathrm{~mL})$. After stirring for $1.5 \mathrm{~h}$ the colourless mixture was concentrated under reduced pressure with a gentle stream of nitrogen and the ensuing residue was subjected to purification by flash chromatography (silica, 10:0.5 $v / v$ DCM/MeOH). Concentration of the appropriate fractions afforded $27(11 \mathrm{mg}, 6 \%)$ as a colourless foam contaminated with ca. $20 \%$ of an unknown impurity.

$[\alpha]_{D}^{21}-15.1\left(c=1.0, \mathrm{CDCl}_{3}\right)$.

${ }^{1}$ H NMR (700 MHz, Methanol-d $\mathbf{d}_{4}$ ) NHs not observed $\delta 7.85$ (app. t, $J=1.9 \mathrm{~Hz}, 1 \mathrm{H}$ ), 7.78 (app. dt, $J=7.8,1.3 \mathrm{~Hz}, 1 \mathrm{H}), 7.64$ (ddd, $J=8.0,2.2,1.1 \mathrm{~Hz}, 1 \mathrm{H}), 7.56$ (t, $J=7.9 \mathrm{~Hz}, 1 \mathrm{H}), 7.31-7.29$ (m, 2H), $7.28-7.25(\mathrm{~m}, 2 \mathrm{H}), 7.20-7.17(\mathrm{~m}, 1 \mathrm{H}), 4.90(\mathrm{dd}, J=9.7,5.4 \mathrm{~Hz}, 1 \mathrm{H}), 4.79$ (app. t, $J=2.0 \mathrm{~Hz}$, $1 \mathrm{H}), 3.97-3.96(\mathrm{~m}, 2 \mathrm{H}), 3.85(\mathrm{~s}, 3 \mathrm{H}), 3.71(\mathrm{~s}, 3 \mathrm{H}), 3.33-3.31(\mathrm{~m}, 1 \mathrm{H}), 3.30(\mathrm{~s}, 3 \mathrm{H}), 3.05(\mathrm{dd}, J=$ 14.0, $9.6 \mathrm{~Hz}, 1 \mathrm{H}), 2.68-2.64(\mathrm{~m}, 2 \mathrm{H}), 2.23-2.19(\mathrm{~m}, 2 \mathrm{H})$.

${ }^{13}$ C NMR (176 MHz, Methanol-d $\left.\boldsymbol{d}_{4}\right) \delta 174.1,171.6,168.7,166.0,160.6,160.1,138.6,136.6,132.9$, $130.5,130.5,130.3,129.5,128.8,127.8,126.1,74.8,62.7,61.2,56.5,52.6,44.3,42.0,38.7,32.9$.

LRMS (ESI $\left.{ }^{+}\right): m / z$ (rel. int.) $601(100)[\mathrm{M}+\mathrm{Na}]^{+}$.

HRMS (ESI ${ }^{+}$): calc'd for $\mathrm{C}_{28} \mathrm{H}_{30} \mathrm{~N}_{6} \mathrm{NaO}_{8}[\mathrm{M}+\mathrm{Na}]^{+}: 601.2017$, found: 601.2017

IR: $\mathrm{V}_{\max }=1725,1646,1390,728 \mathrm{~cm}^{-1}$. 


\section{Crystallographic Studies}

Data for compounds 11a, 11b, 11c, 13a, 13c, 14a, 14b and 14c were measured on a Rigaku SuperNova diffractometer (using the radiation specified). Data collection, cell refinement and data reduction employed the CrysAlis PRO program ${ }^{13}$ while SHELXT ${ }^{14}$ and SHELXL ${ }^{15}$ were used for structure solution and refinement. Atomic coordinates, bond lengths and angles, and displacement parameters have been deposited at the Cambridge Crystallographic Data Centre. These data can be obtained free-of-charge via www.ccdc.cam.ac.uk/data_request/cif, by emailing data_request@ccdc.cam.ac.uk, or by contacting The Cambridge Crystallographic Data Centre, 12 Union Road, Cambridge CB2 1EZ, UK; fax: +44 1223336033. 


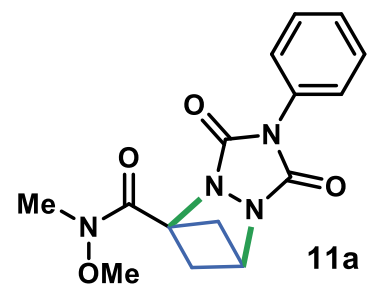

\begin{tabular}{|llll|}
\hline Formula & $\mathrm{C}_{15} \mathrm{H}_{16} \mathrm{~N}_{4} \mathrm{O}_{4}$ & $Z^{\prime}$ & 1 \\
$D_{\text {calc. }} / \mathrm{g} \mathrm{cm}^{-3}$ & 1.386 & Wavelength $/ \AA$ & 1.54184 \\
$\mu / \mathrm{mm}^{-1}$ & 0.862 & Radiation type & $\mathrm{CuK}_{\alpha}$ \\
Formula Weight & 316.32 & $\Theta_{\min }{ }^{\circ}$ & 5.236 \\
Colour & colourless & $\Theta_{\max }{ }^{\circ}$ & 73.777 \\
Shape & plate & Measured Refl. & 8282 \\
Size $/ \mathrm{mm}^{3}$ & $0.32 \times 0.20 \times 0.04$ & Independent Refl. & 3055 \\
$T / \mathrm{K}$ & $150.00(10)$ & Reflections with I $>2(\mathrm{I})$ & 2747 \\
Crystal System & monoclinic & $R_{\text {int }}$ & 0.0217 \\
Space Group & $P 21 / c$ & Parameters & 230 \\
$a / \AA$ & $15.1091(3)$ & Restraints & 0 \\
$b / \AA$ & $6.42570(10)$ & Largest Peak & 0.184 \\
$c / \AA$ & $17.1388(3)$ & Deepest Hole & -0.183 \\
$\alpha /^{\circ}$ & 90 & GooF & 1.022 \\
$\beta /^{\circ}$ & $114.341(2)$ & $w R_{2}$ (all data) & 0.0855 \\
$\gamma /^{\circ}$ & 90 & $w R_{2}$ & 0.0819 \\
$\mathrm{~V} / \AA^{3}$ & $1516.04(5)$ & $R_{1}$ (all data) & 0.0372 \\
$Z$ & 4 & $R_{1}$ & 0.0331 \\
\hline
\end{tabular}

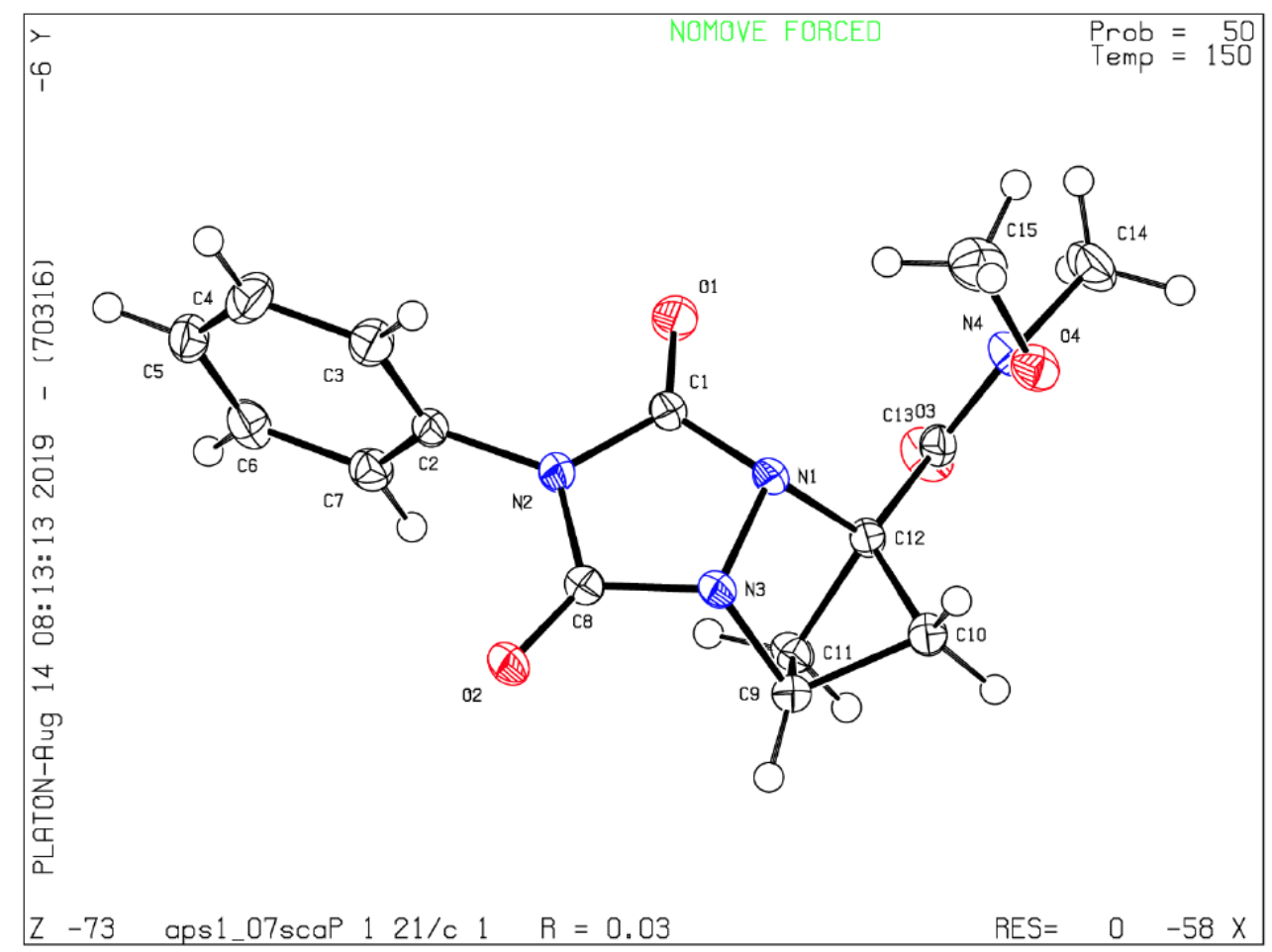

Structure of compound 11a (CCDC 2124646). Anisotropic displacement ellipsoids show 50\% probability levels. 

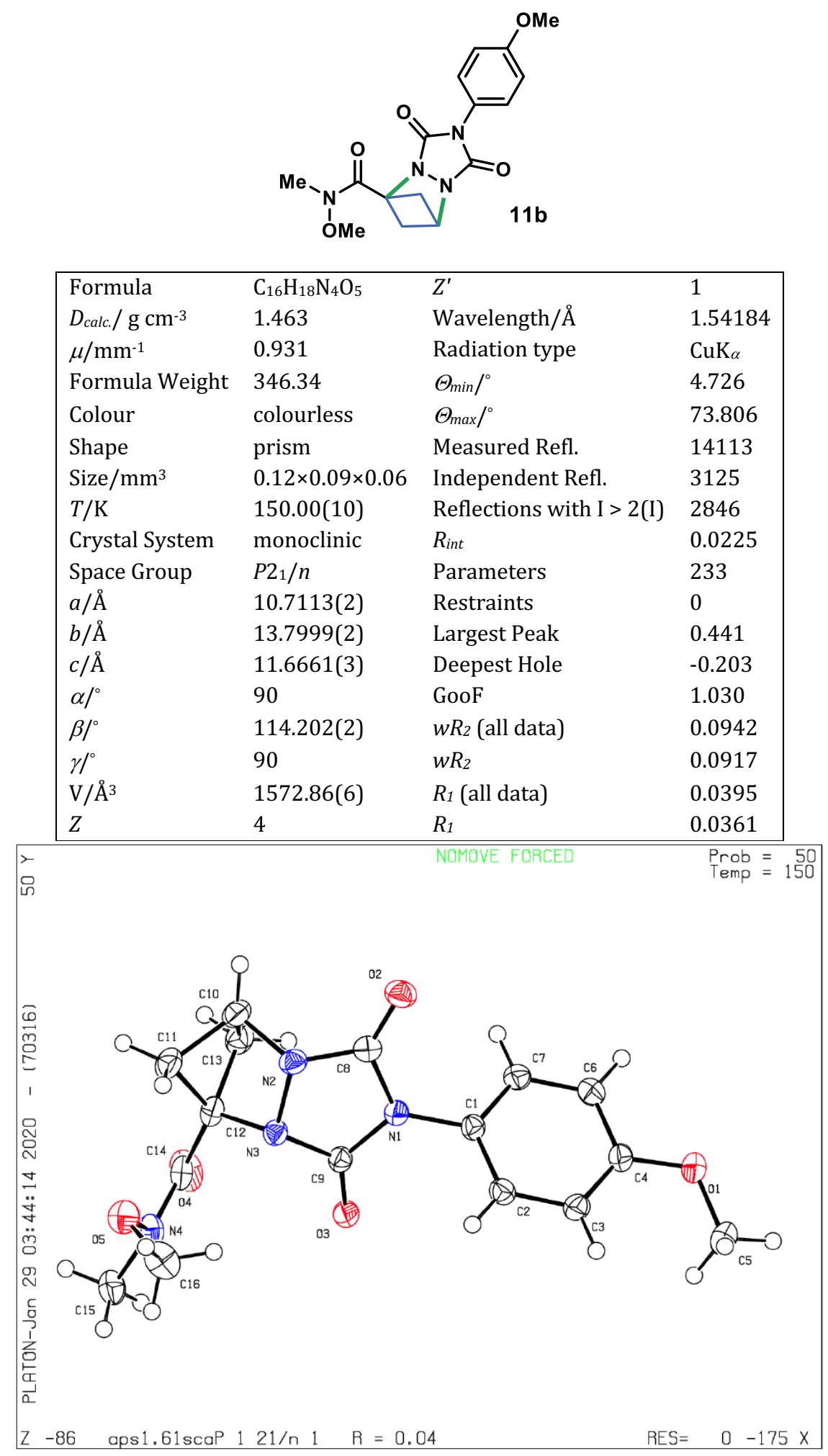

Structure of compound 11b (CCDC 2124650). Anisotropic displacement ellipsoids show 50\% probability levels. 


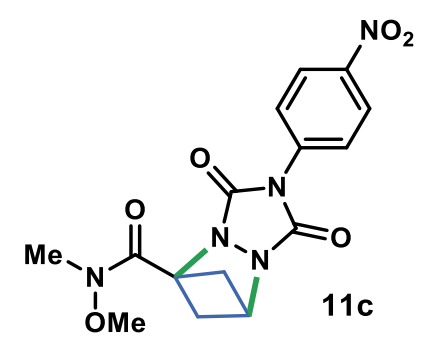

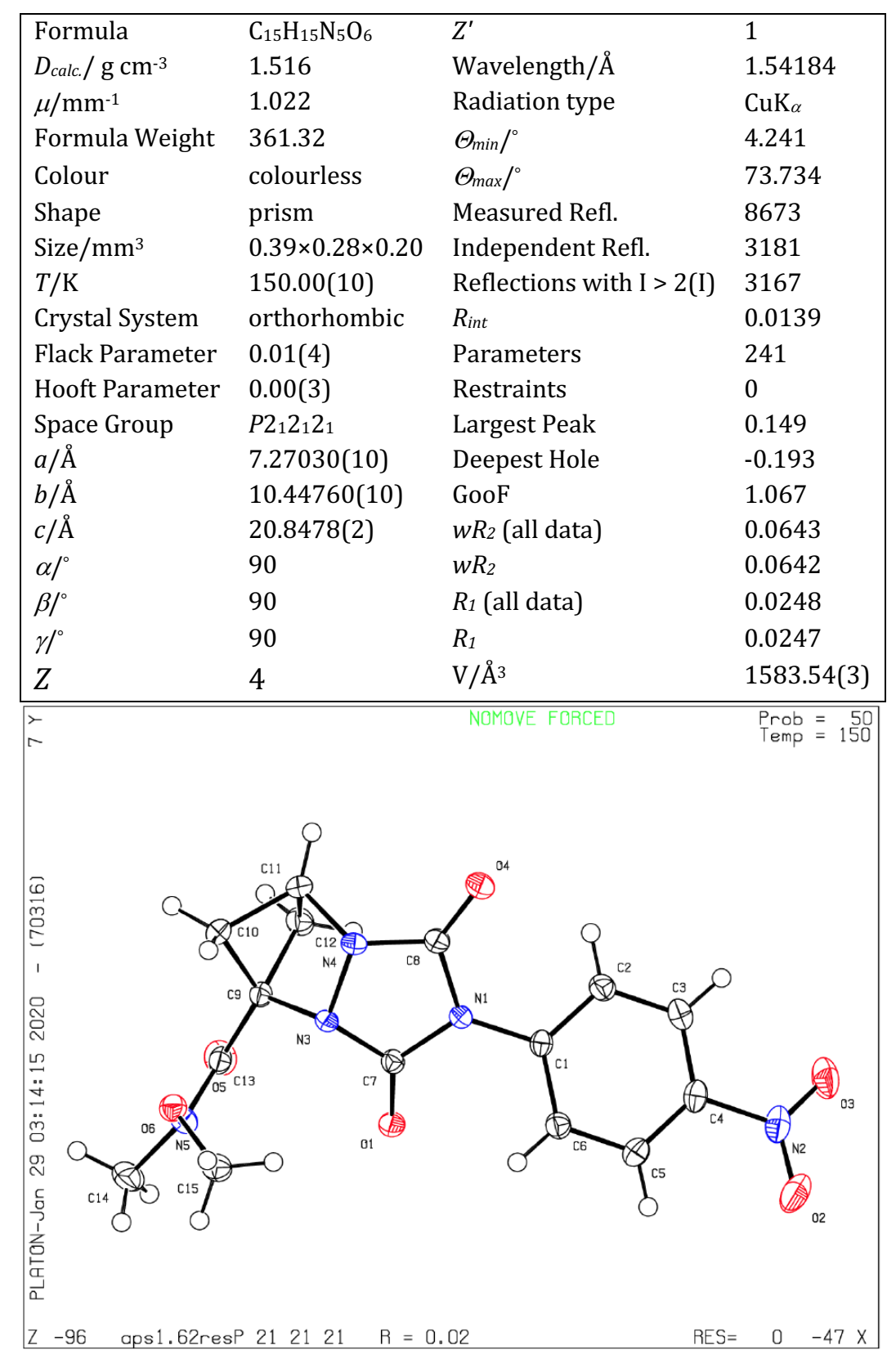

Structure of compound 11c (CCDC 2124652). Anisotropic displacement ellipsoids show 50\% probability levels. 

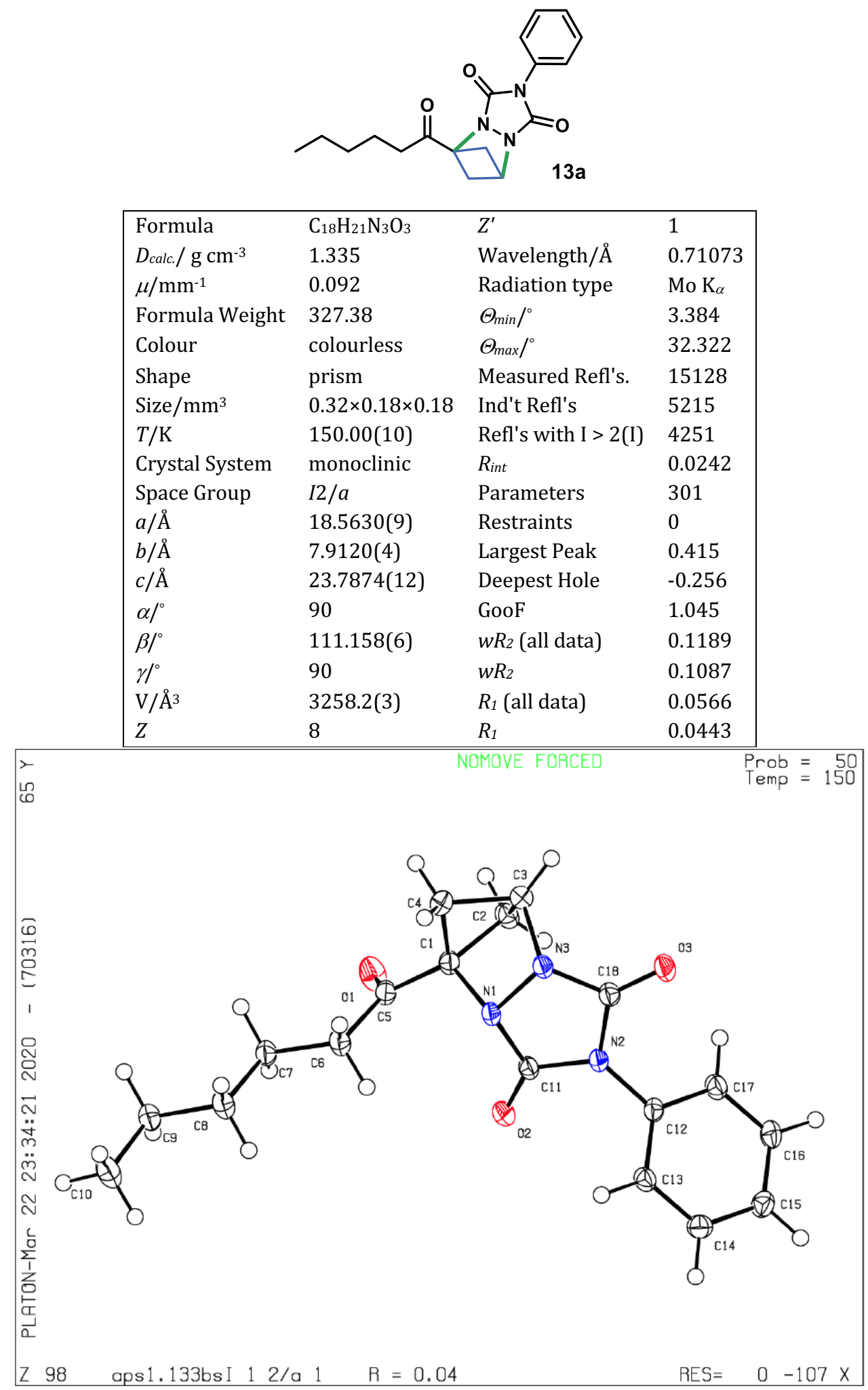

Structure of compound 13a (CCDC 2124653). Anisotropic displacement ellipsoids show 50\% probability levels. 

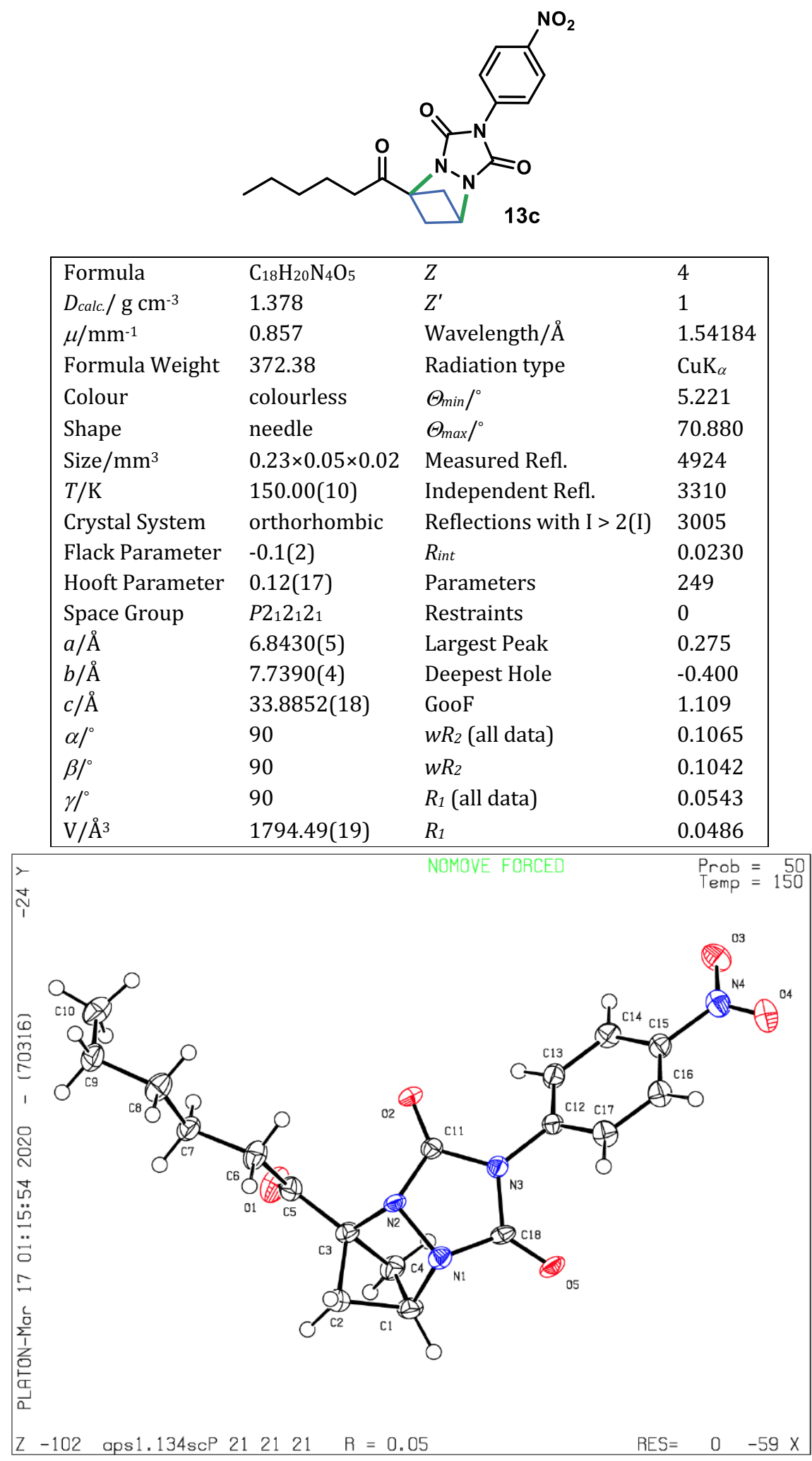

Structure of compound 13c (CCDC 2124654). Anisotropic displacement ellipsoids show 50\% probability levels. 

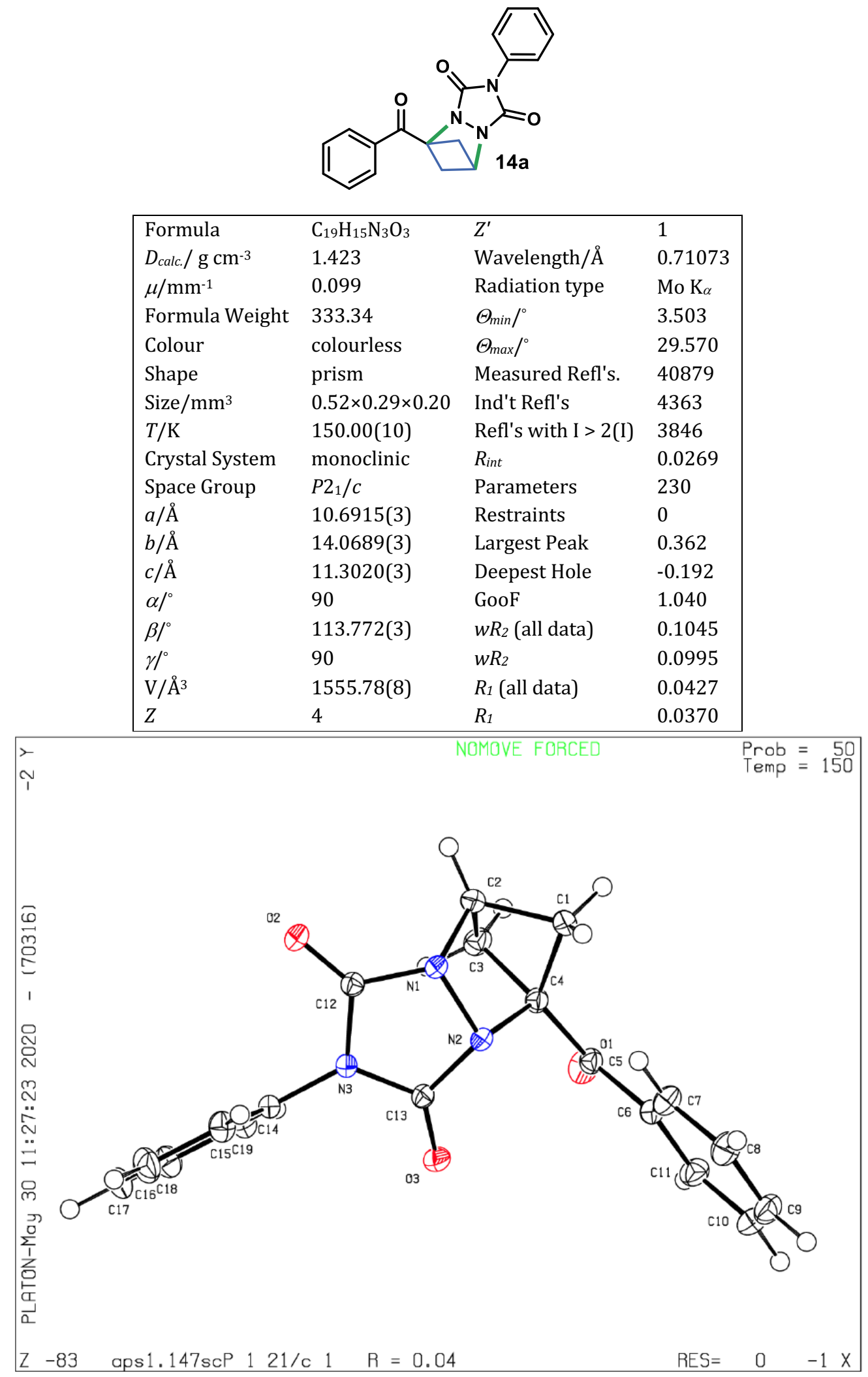

Structure of compound 14a (CCDC 2124661). Anisotropic displacement ellipsoids show 50\% probability levels. 

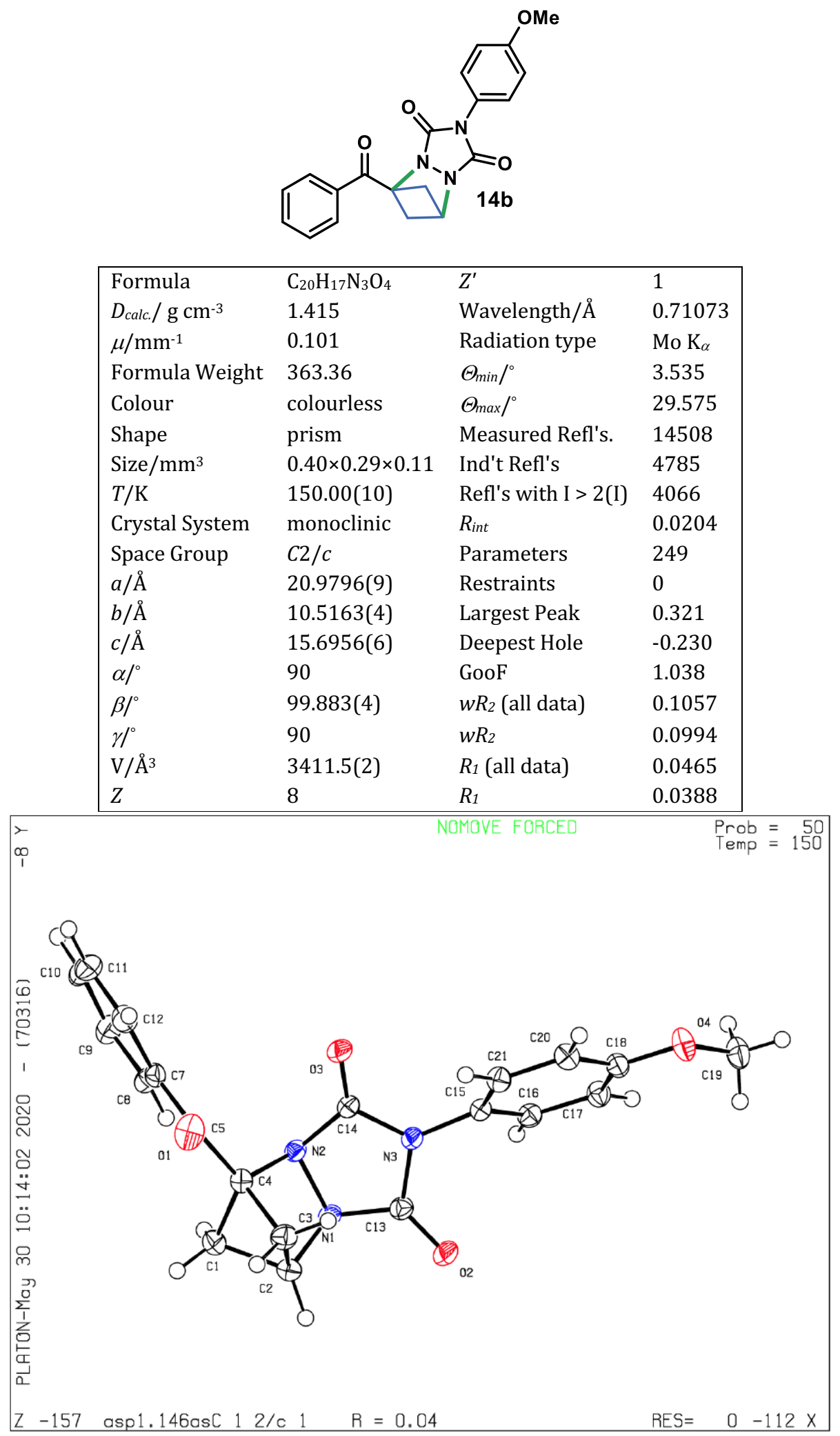

Structure of compound 14b (CCDC 2124662). Anisotropic displacement ellipsoids show 50\% probability levels. 


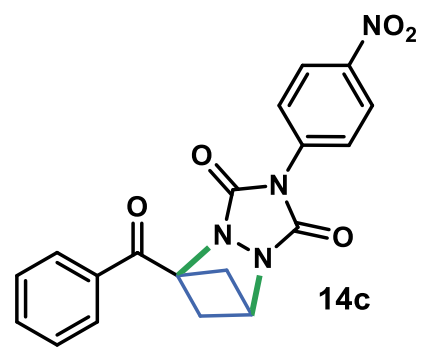

\begin{tabular}{|llll|}
\hline Formula & $\mathrm{C}_{19} \mathrm{H}_{14} \mathrm{~N}_{4} \mathrm{O}_{5}$ & $Z$ & 2 \\
$D_{\text {calc. }} / \mathrm{g} \mathrm{cm}^{-3}$ & 1.487 & $Z^{\prime}$ & 1 \\
$\mu / \mathrm{mm}^{-1}$ & 0.930 & Wavelength $/ \AA$ & 1.54184 \\
Formula Weight & 378.34 & Radiation type & $\mathrm{Cu} \mathrm{K} \alpha$ \\
Colour & light yellow & $\Theta_{\min }{ }^{\circ}$ & 5.479 \\
Shape & plate & $\Theta_{\max }{ }^{\circ}$ & 73.942 \\
Size $/ \mathrm{mm}^{3}$ & $0.20 \times 0.11 \times 0.03$ & Measured Refl's. & 13659 \\
$T / \mathrm{K}$ & $150.00(10)$ & Ind't Refl's & 3407 \\
Crystal System & monoclinic & Refl's with I $>2(\mathrm{I})$ & 3329 \\
Flack Parameter & $0.04(9)$ & $R_{\text {int }}$ & 0.0304 \\
Hooft Parameter & $0.03(8)$ & Parameters & 257 \\
Space Group & $P 21$ & Restraints & 1 \\
$a / \AA$ & $7.39400(10)$ & Largest Peak & 0.127 \\
$b / \AA$ & $7.07760(10)$ & Deepest Hole & -0.123 \\
$c / \AA$ & $16.1924(2)$ & GooF & 1.064 \\
$\alpha{ }^{\circ}$ & 90 & $w R_{2}$ (all data) & 0.0644 \\
$\beta /{ }^{\circ}$ & $94.2190(10)$ & $w R_{2}$ & 0.0637 \\
$\gamma /{ }^{\circ}$ & 90 & $R_{1}$ (all data) & 0.0265 \\
$\mathrm{~V} / \AA \AA^{3}$ & $845.08(2)$ & $R_{1}$ & 0.0256 \\
\hline
\end{tabular}

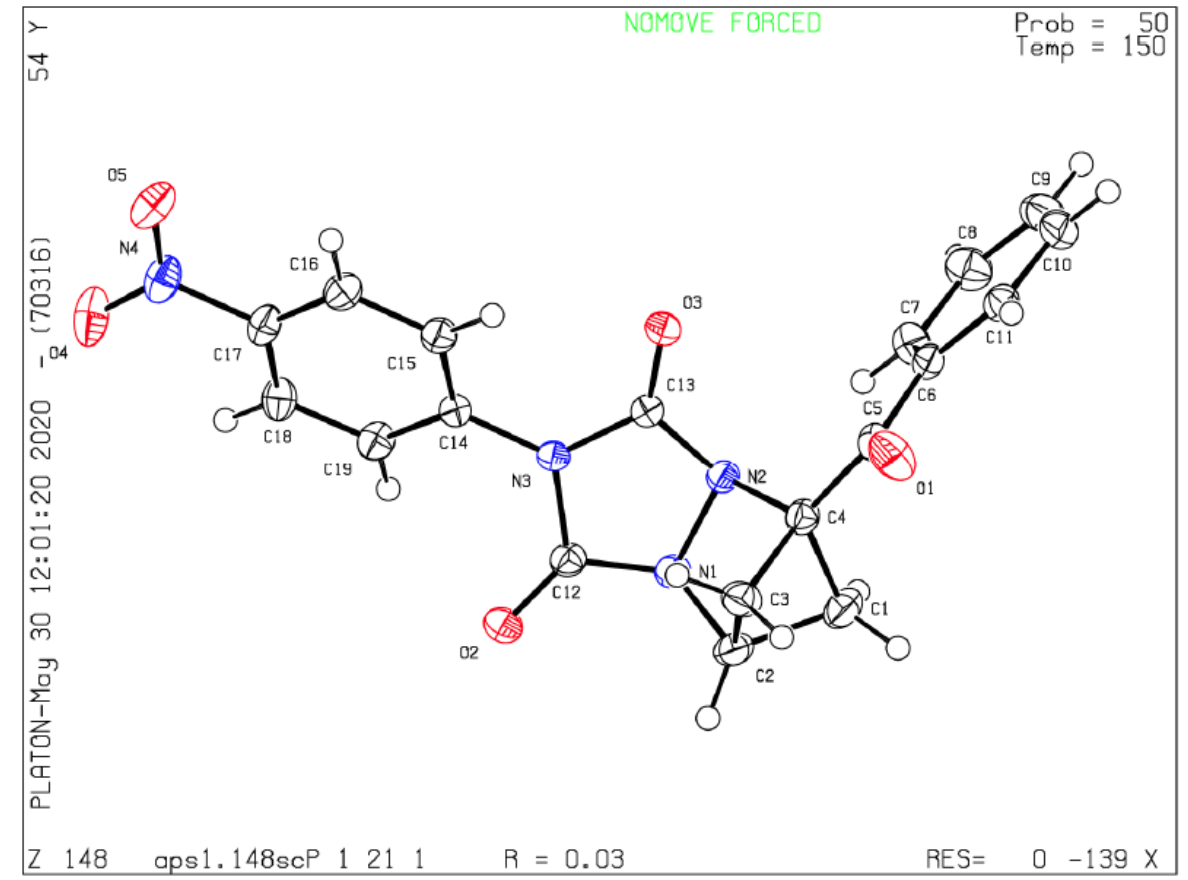

Structure of compound 14c (CCDC 2124663). Anisotropic displacement ellipsoids show 50\% probability levels 


\section{References}

1. Still, W. C.; Kahn, M.; Mitra, A., Rapid chromatographic technique for preparative separations with moderate resolution. J. Org. Chem. 1978, 43 (14), 2923-2925.

2. Pangborn, A. B.; Giardello, M. A.; Grubbs, R. H.; Rosen, R. K.; Timmers, F. J., Safe and Convenient Procedure for Solvent Purification. Organometallics 1996, 15 (5), 1518-1520.

3. (a) Schwartz, B. D.; Zhang, M. Y.; Attard, R. H.; Gardiner, M. G.; Malins, L. R., Structurally Diverse Acyl Bicyclobutanes: Valuable Strained Electrophiles. Chem. Eur. J. 2020, 26 (13), 2808-2812; (b) Nugent, J.; Schwartz, B. D., N-Methoxy-N-methylcyanoformamide, a Highly Reactive Reagent for the Formation of $\beta$-Keto Weinreb Amides and Unsymmetrical Ketones. Org. Lett. 2016, 18 (15), 3834-3837.

4. Wagh, S. J.; Chowdhury, R.; Mukhopadhyay, S.; Ghosh, S. K., A facile synthesis of 5,5dideutero-4-dimethyl(phenyl)silyl-6-undecyl-tetrahydropyran-2-one as a deuterium labeled synthon for (-)-tetrahydrolipstatin and (+)- $\delta$-hexadecanolide. J. Labelled Comp. Radiopharm. 2013, 56 (13), 649-654.

5. Zolfigol, M. A.; Bagherzadeh, M.; Mallakpour, S.; Chehardoli, G.; Ghorbani-Choghamarani, A.; Koukabi, N.; Dehghanian, M.; Doroudgar, M., The first report on the catalytic oxidation of urazoles to their corresponding triazolinediones via in situ catalytic generation of $\mathrm{Br}+$ using periodic acid or oxone ${ }^{\circledR} / \mathrm{KBr}$ system. J. Mol. Catal. A Chem. 2007, 270 (1), 219-224.

6. Amey, R. L.; Smart, B. E., Bicyclo[1.1.0]butanes. Reactions with cyclic azo compounds. J. Org. Chem. 1981, 46 (20), 4090-4092.

7. Majima, K.; Yamano, M., Diastereoselective Synthesis of a cis-1,3-Disubstituted Cyclobutane Carboxylic Acid Scaffold for TAK-828F, a Potent Retinoic Acid ReceptorRelated Orphan Receptor (ROR)- $\gamma$ t Inverse Agonist. J. Org. Chem. 2021, 86 (17), 1146411471.

8. Chernykh, A. V.; Radchenko, D. S.; Grygorenko, O. O.; Volochnyuk, D. M.; Shishkina, S. V.; Shishkin, O. V.; Komarov, I. V., Conformationally restricted glutamic acid analogues: stereoisomers of 1-aminospiro[3.3] heptane-1,6-dicarboxylic acid. RSC Adv. 2014, 4 (21), 10894-10902.

9. Ociepa, M.; Wierzba, A. J.; Turkowska, J.; Gryko, D., Polarity-Reversal Strategy for the Functionalization of Electrophilic Strained Molecules via Light-Driven Cobalt Catalysis. $J$. Am. Chem. Soc. 2020, 142 (11), 5355-5361.

10. (a) Kaur, B.; Kaur, M.; Kaur, N.; Garg, S.; Bhatti, R.; Singh, P., Engineered Substrate for Cyclooxygenase-2: A Pentapeptide Isoconformational to Arachidonic Acid for Managing Inflammation. J. Med. Chem. 2019, 62 (13), 6363-6376; (b) Graham, K.; Schmitt-Willich, H.; Frank, D. Radiolabelling Method Using Cycloalkyl Groups. WO Patent WO2011006621, 2011.

11. Pinkert, T.; Das, M.; Schrader, M. L.; Glorius, F., Use of Strain-Release for the Diastereoselective Construction of Quaternary Carbon Centers. J. Am. Chem. Soc. 2021, 143 (20), 7648-7654.

12. Grzyb, J. A.; Shen, M.; Yoshina-Ishii, C.; Chi, W.; Brown, R. S.; Batey, R. A., Carbamoylimidazolium and thiocarbamoylimidazolium salts: novel reagents for the synthesis of ureas, thioureas, carbamates, thiocarbamates and amides. Tetrahedron 2005, 61 (30), 7153 7175.

13. CrysAlis PRO Version 1.171.37.35h (release 09-02-2015 CrysAlis171.NET) (compiled Feb 9 2015,16:26:32) Agilent Technologies: Oxfordshire, UK.

14. Sheldrick, G. M. SHELXT - Integrated Space-Group and Crystal-Structure Determination. Acta Cryst. 2015, A71, 3-8.

15. Sheldrick, G. M. Crystal Structure Refinement with SHELXL. Acta Cryst. 2015, C71, 3-8. 


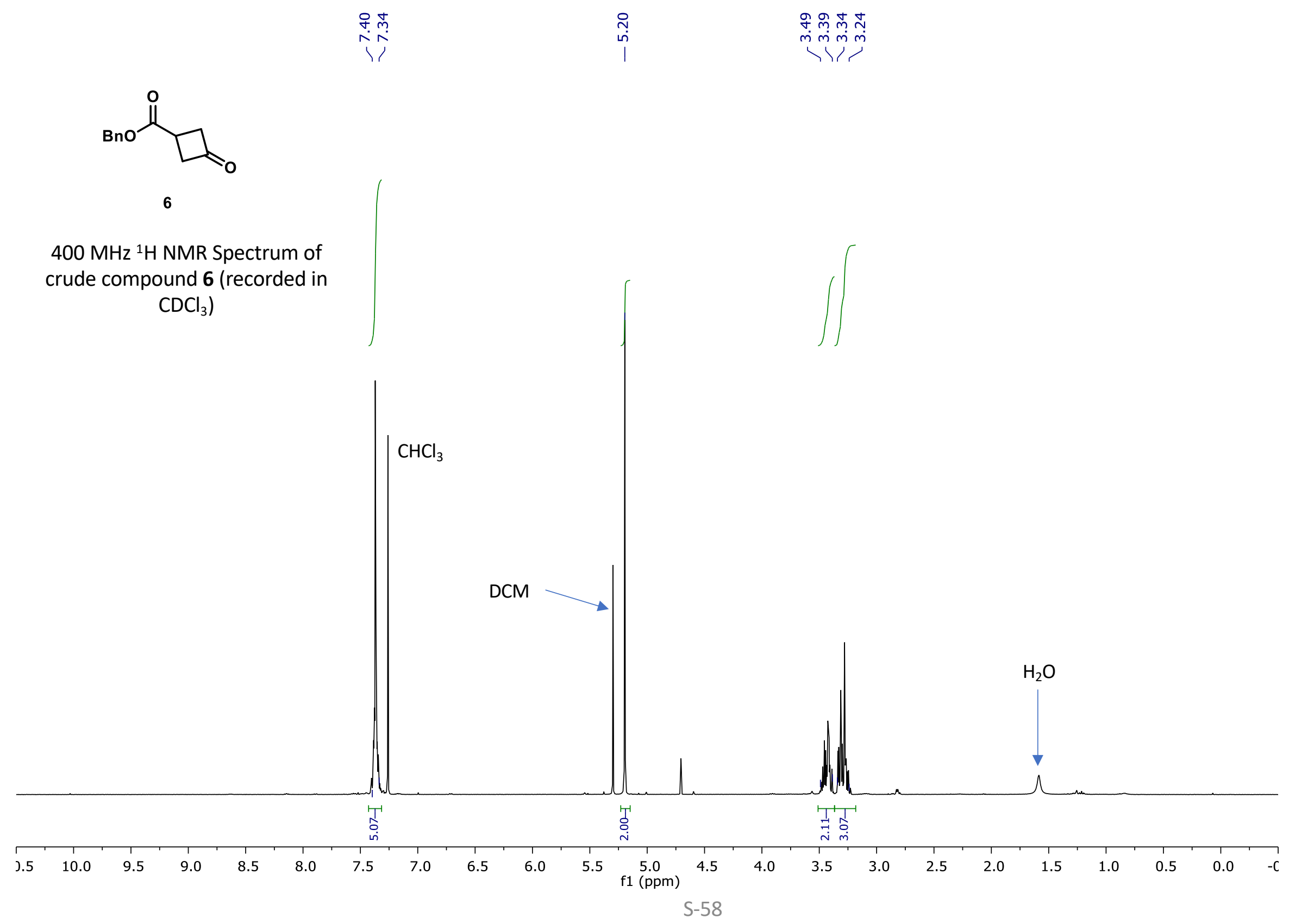




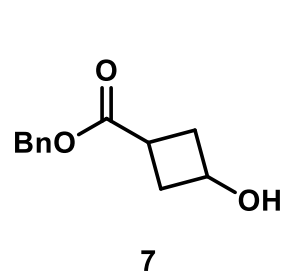

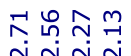

$400 \mathrm{MHz}{ }^{1} \mathrm{H}$ NMR Spectrum of crude compound $\mathbf{7}$ (recorded in $\mathrm{CDCl}_{3}$ )

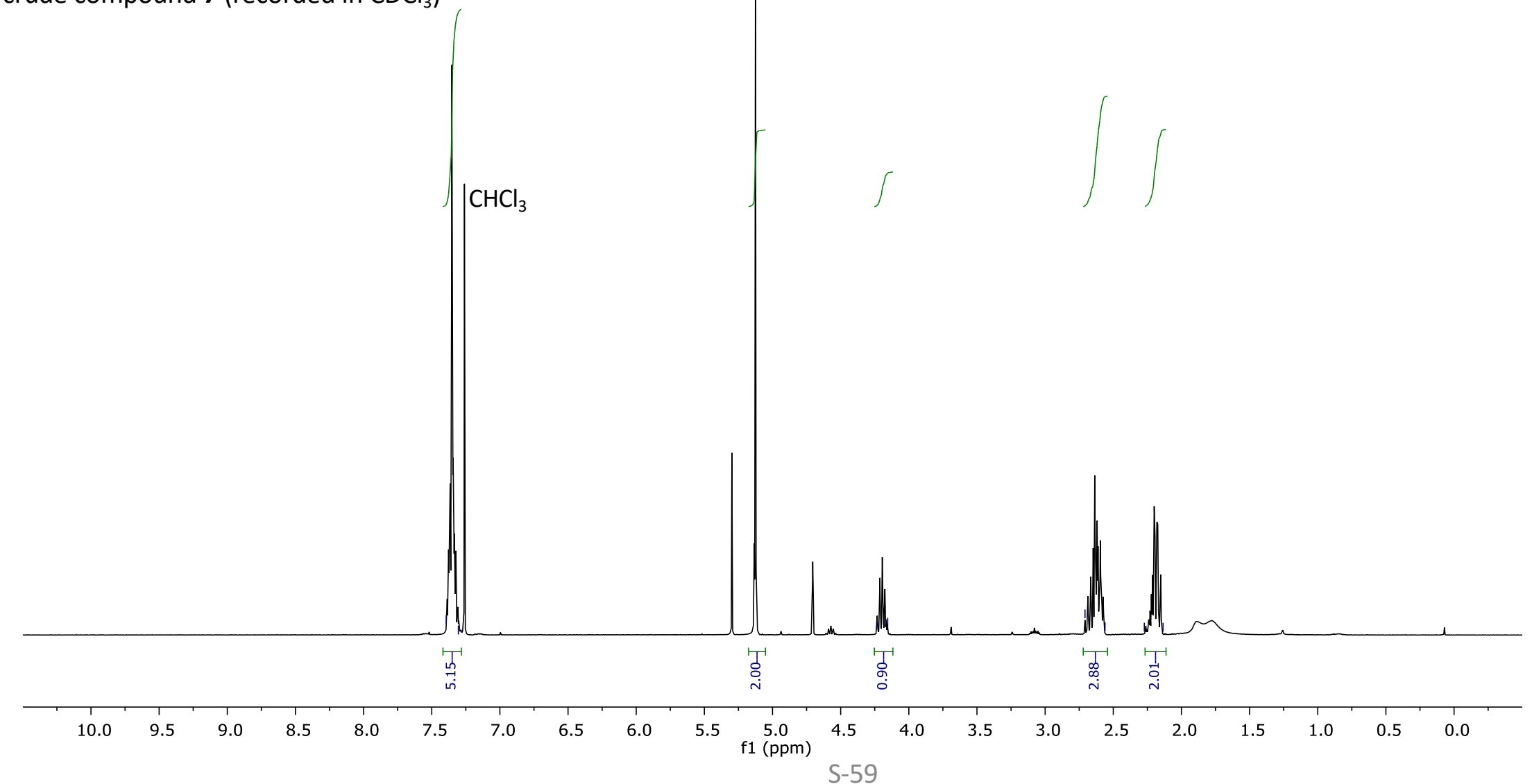




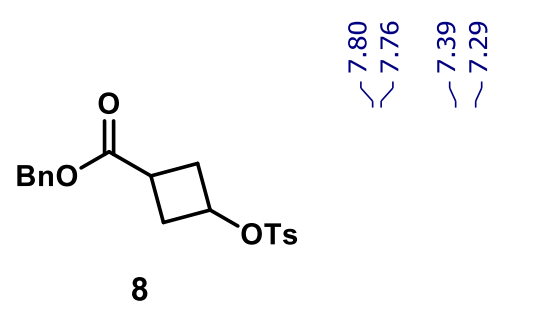

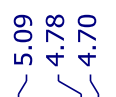

ㅊํำำ ำ 이

$00 \mathrm{MHz}{ }^{1} \mathrm{H}$ NMR Spectrum of

compound $\mathbf{8}$ (recorded in $\mathrm{CDCl}_{3}$ )

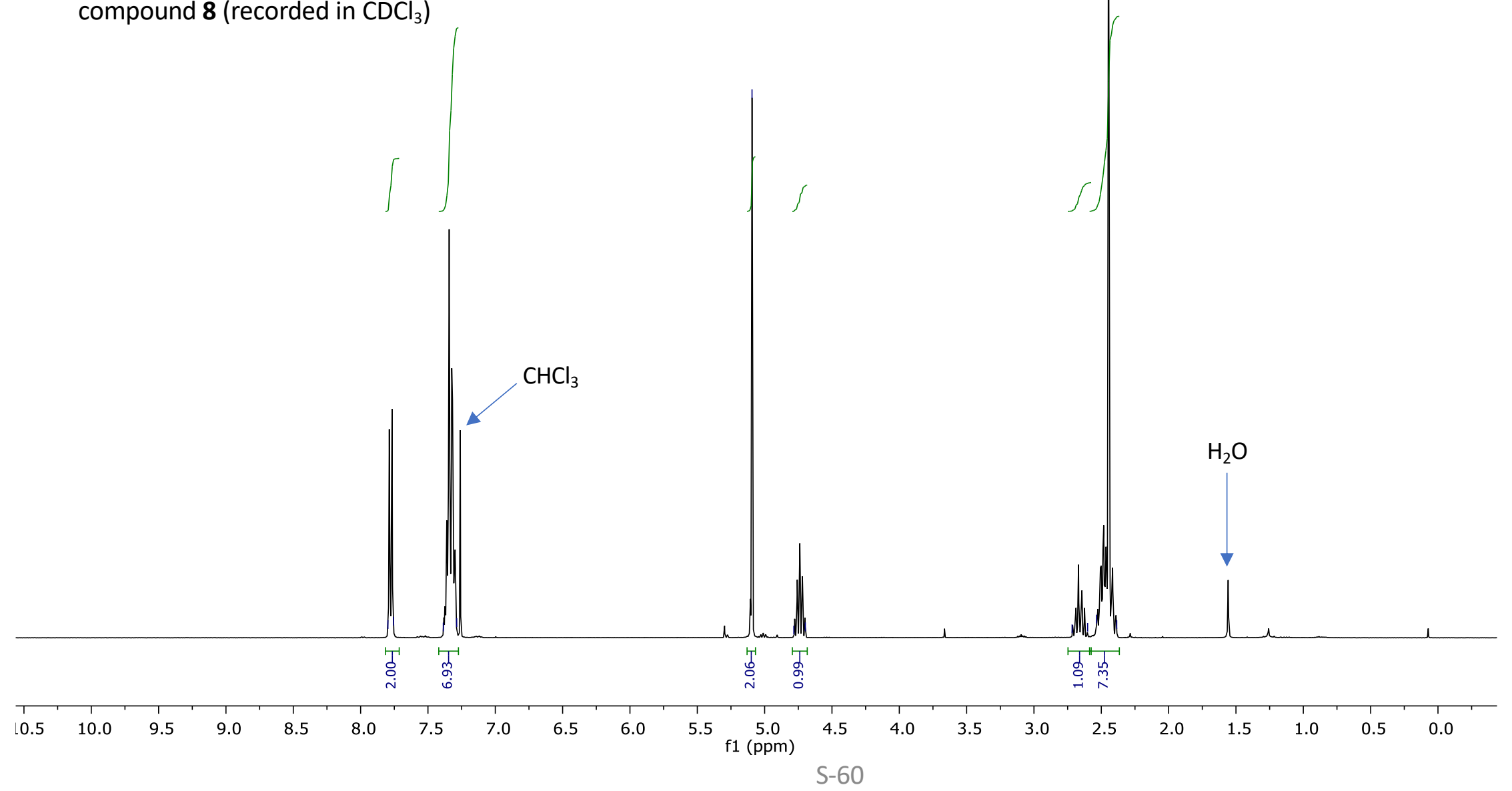


$\underset{\substack{n \\ \stackrel{n}{n}}}{\stackrel{r}{1}}$

|<smiles>O=C(O[GaH2])C1CC([18OH])C1</smiles>

8

$101 \mathrm{MHz}{ }^{13} \mathrm{C}$ NMR Spectrum of compound $\mathbf{8}$ (recorded in $\mathrm{CDCl}_{3}$ )

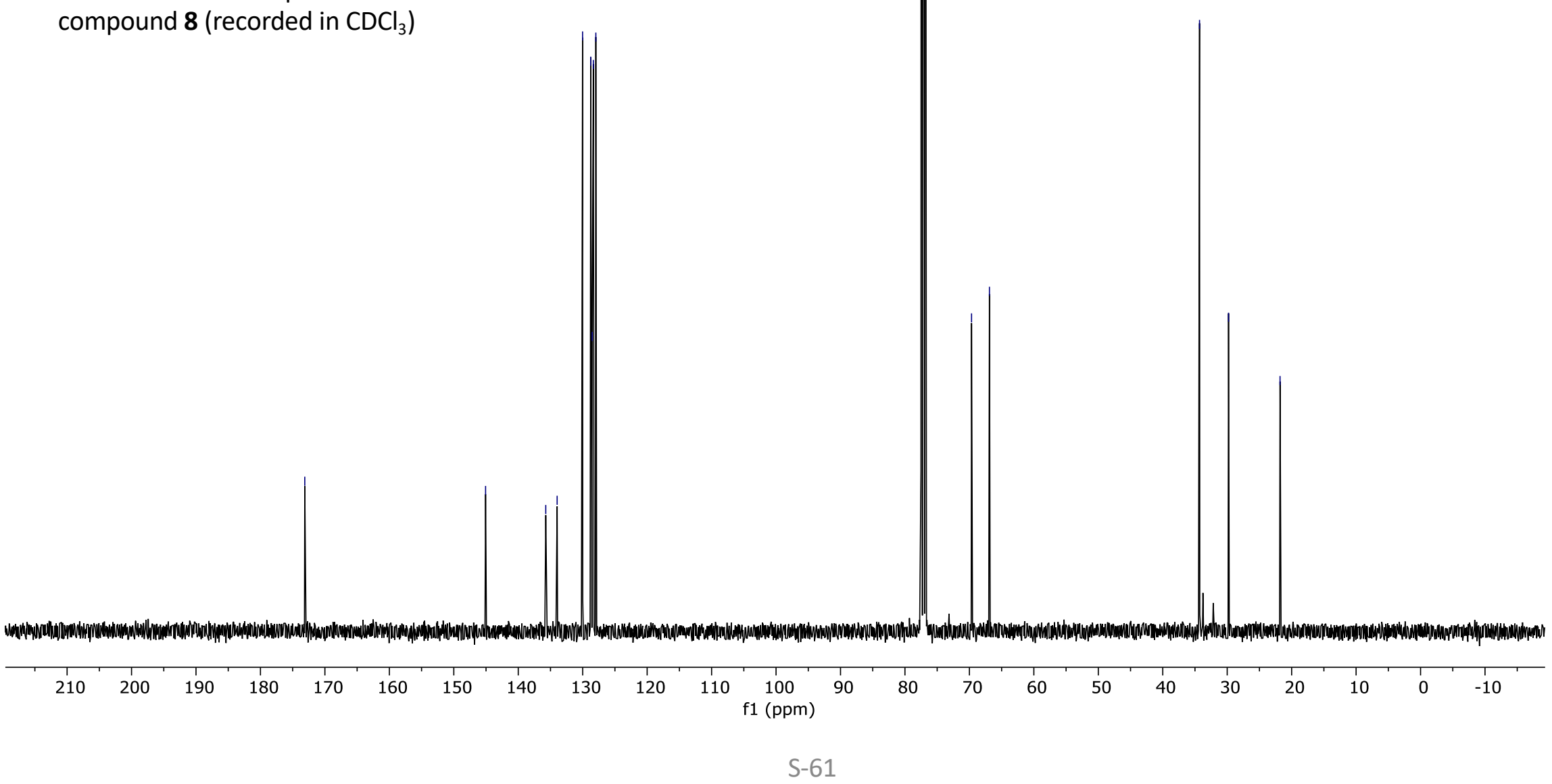




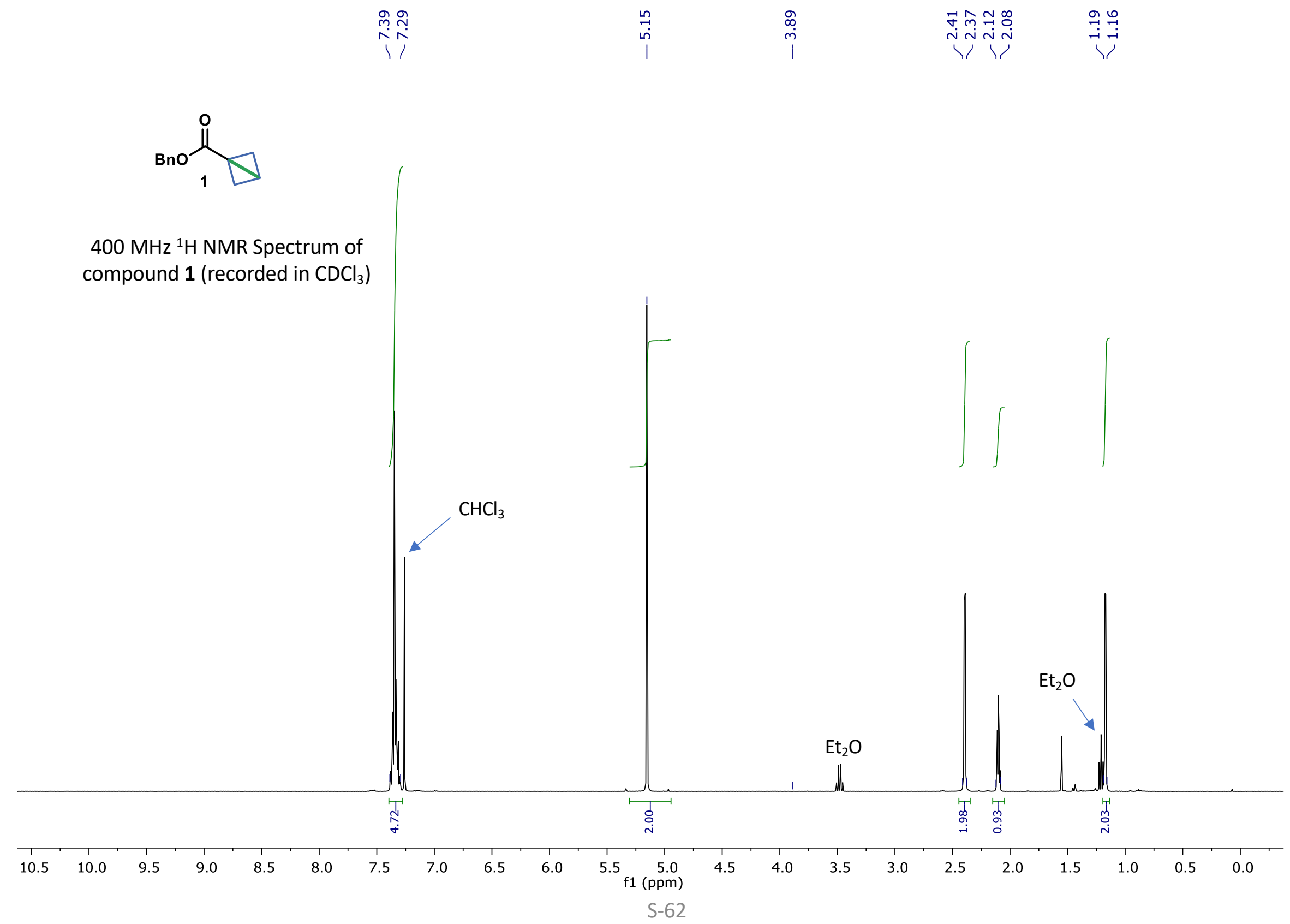




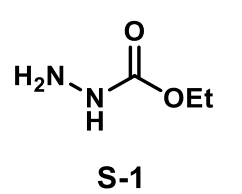

$400 \mathrm{MHz}{ }^{1} \mathrm{H}$ NMR Spectrum of compound S-1 (recorded in $\mathrm{CDCl}_{3}$ )

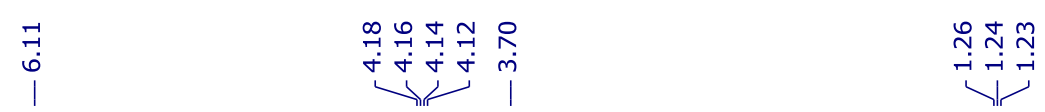

i-
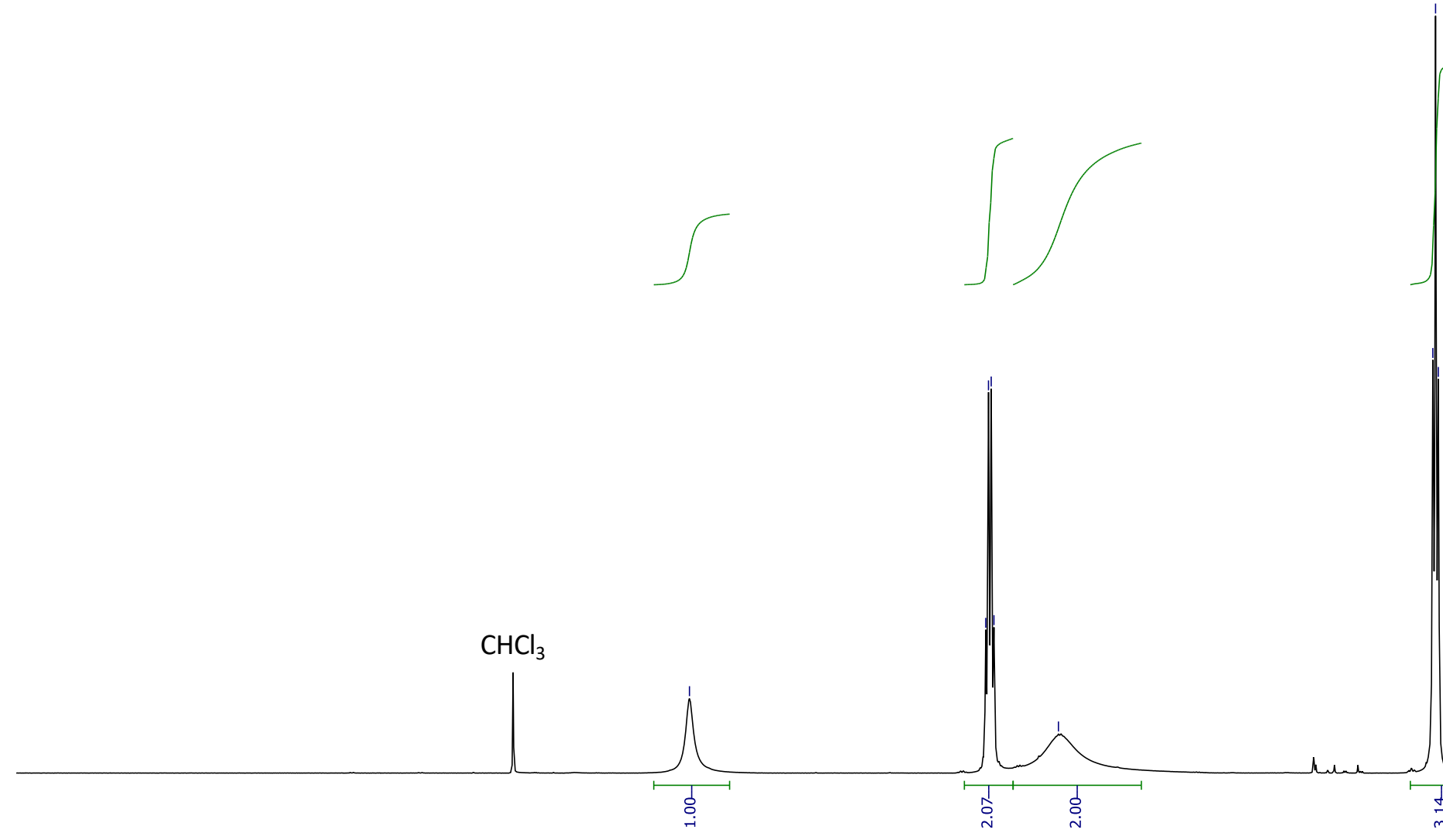

$3.5 \quad 10.0$
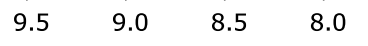

7.5
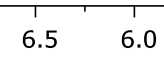

$5.5 \quad 5.0$ f1 (ppm) 


$$
{ }_{\mathrm{H}_{2} \mathrm{~N}_{\mathrm{H}} \mathrm{N}_{\mathrm{OEt}}}^{\mathrm{O}}
$$

S-1

$101 \mathrm{MHz}{ }^{13} \mathrm{C}$ NMR Spectrum of compound S-1 (recorded in $\mathrm{CDCl}_{3}$ )

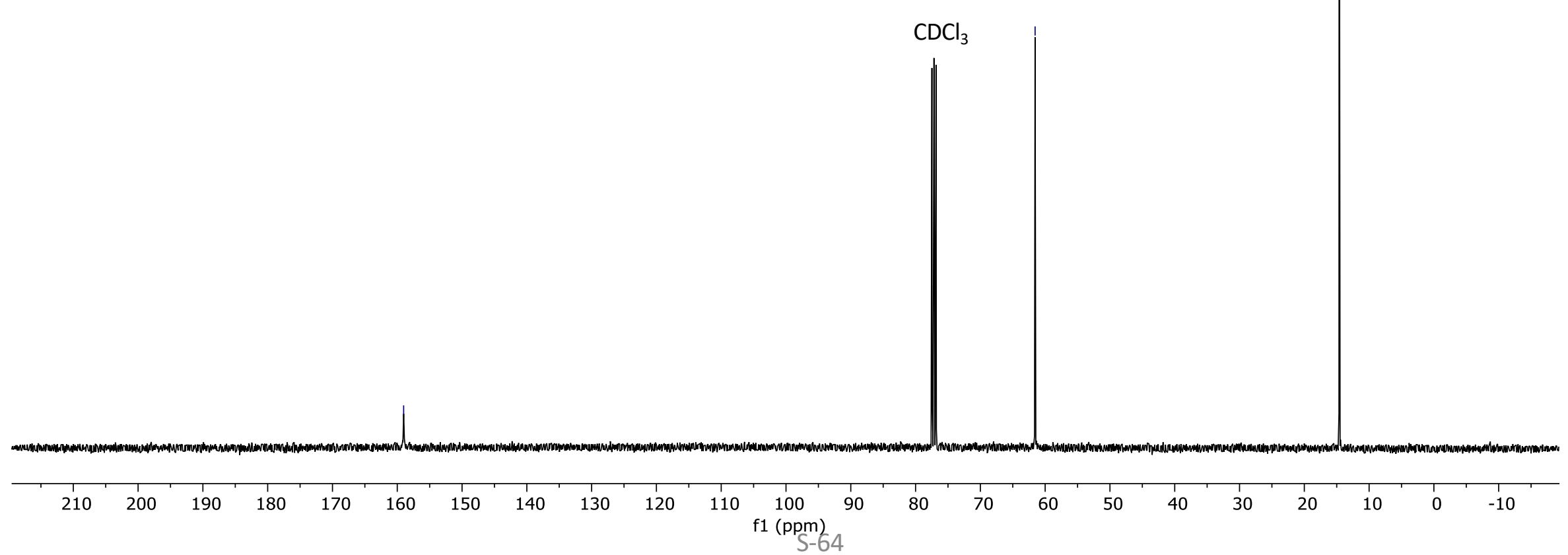




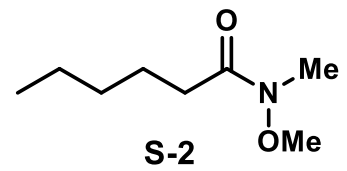

$400 \mathrm{MHz}{ }^{1} \mathrm{H}$ NMR Spectrum of compound S-2 (recorded in $\mathrm{CDCl}_{3}$ )

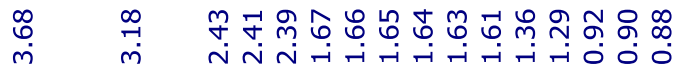

m n

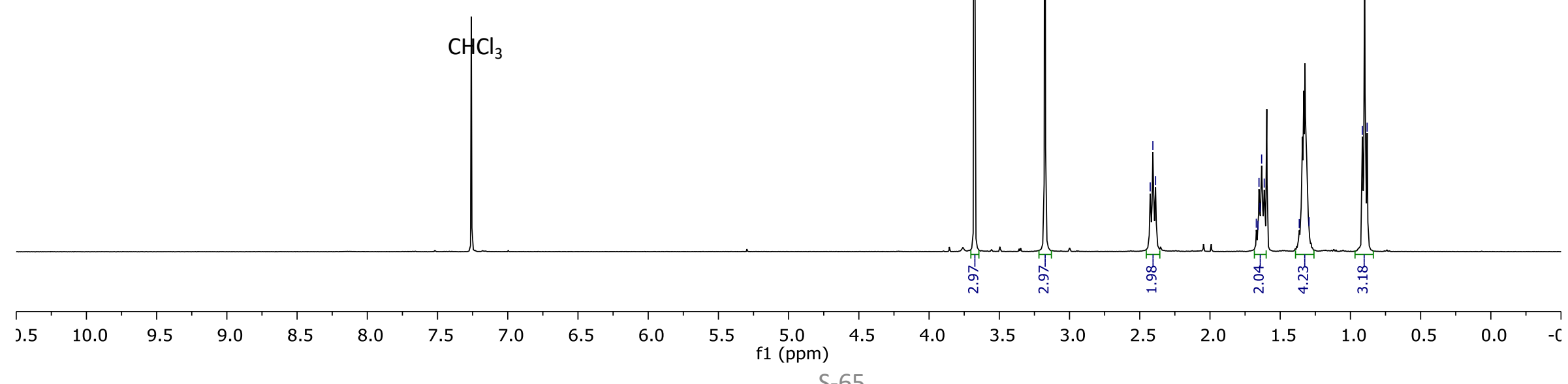




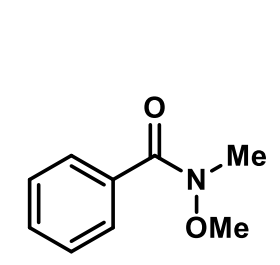

S-3

$400 \mathrm{MHz}{ }^{1} \mathrm{H}$ NMR Spectrum of

compound S-3 (recorded in $\mathrm{CDCl}_{3}$ )

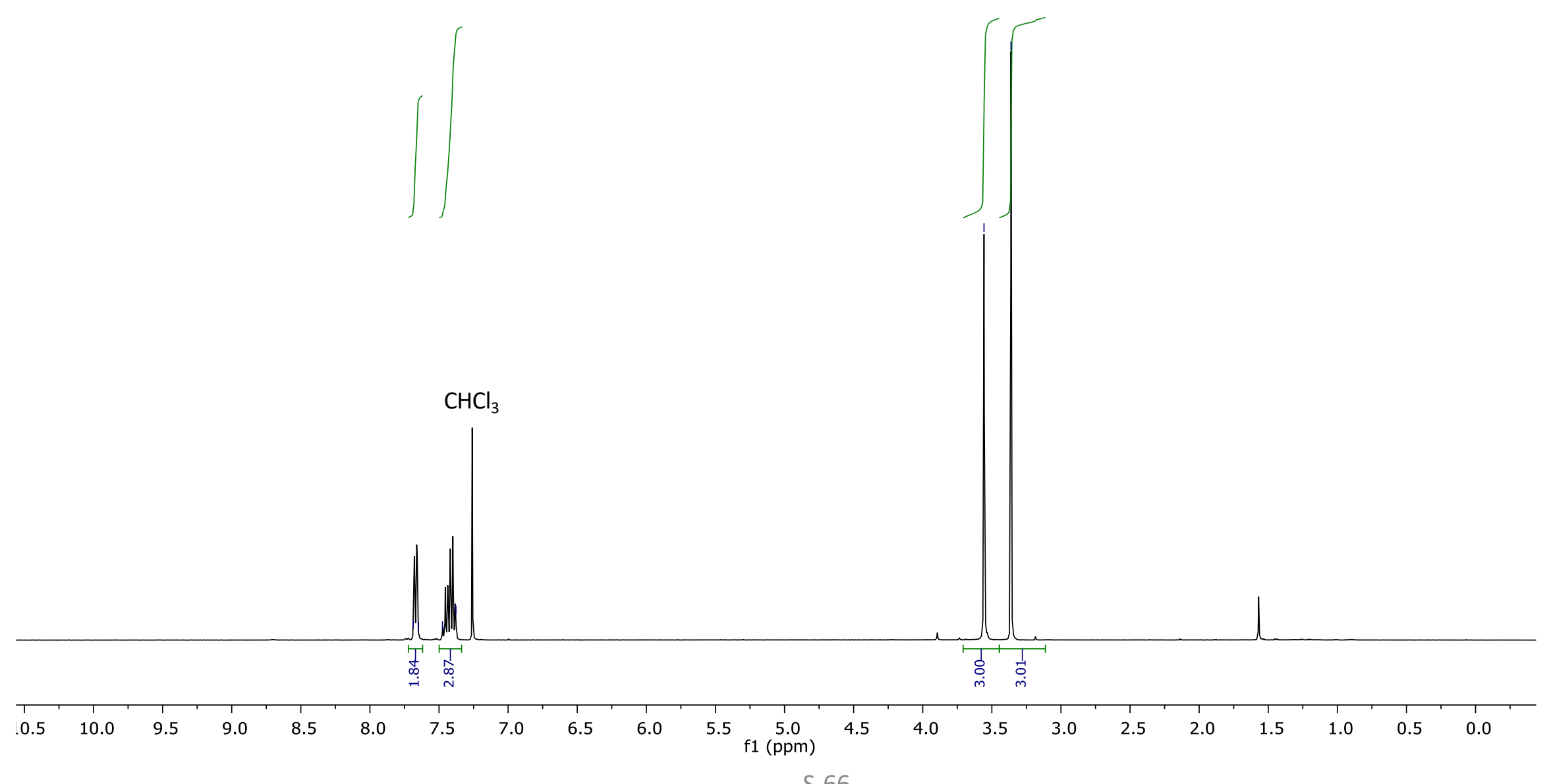




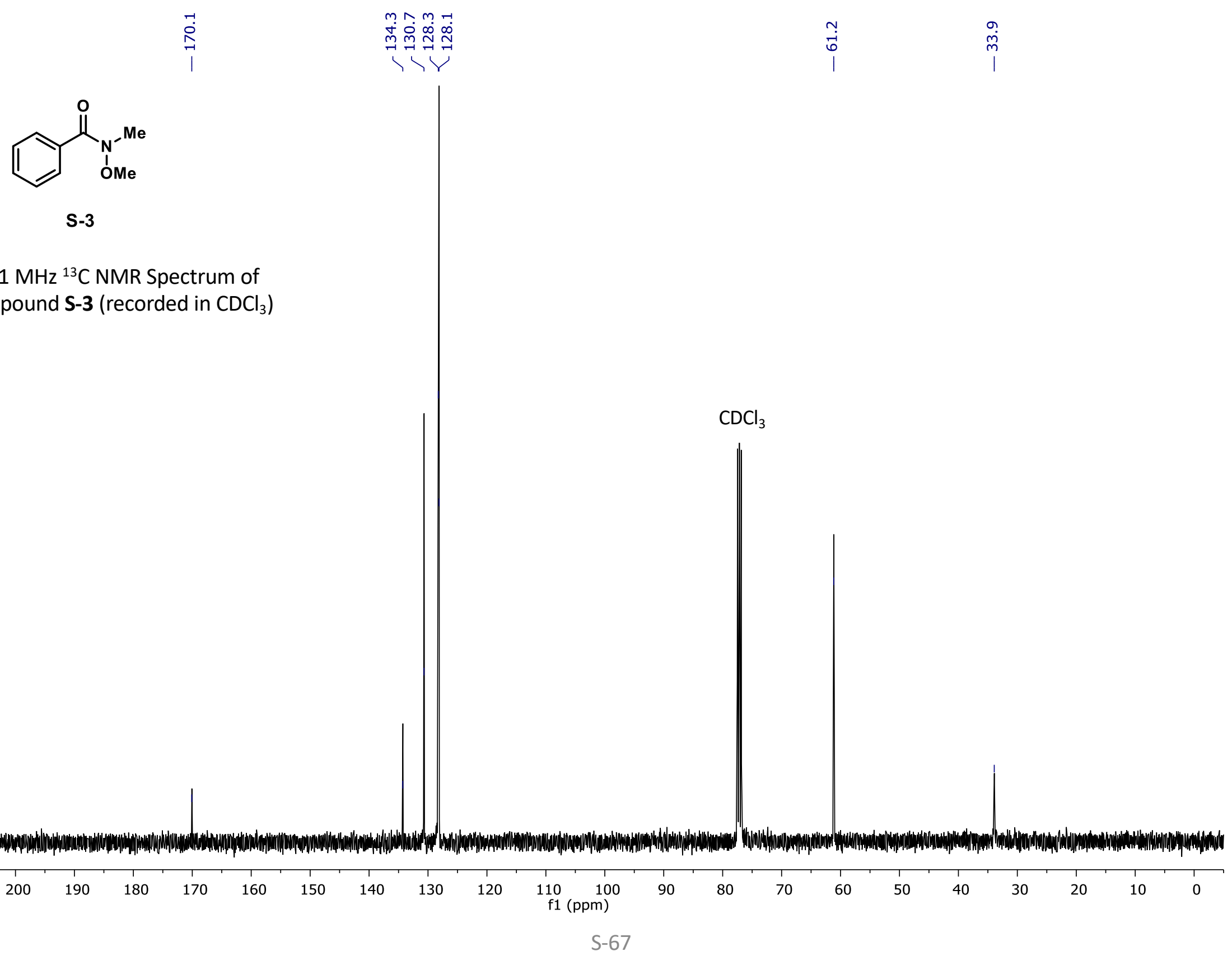




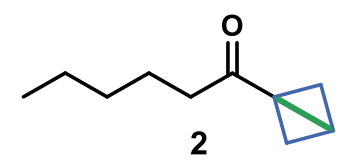

$400 \mathrm{MHz}{ }^{1} \mathrm{H}$ NMR Spectrum of compound $\mathbf{2}$ (recorded in $\mathrm{CDCl}_{3}$ )

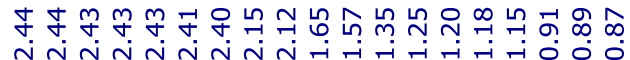

$\mathrm{CHCl}_{3}$
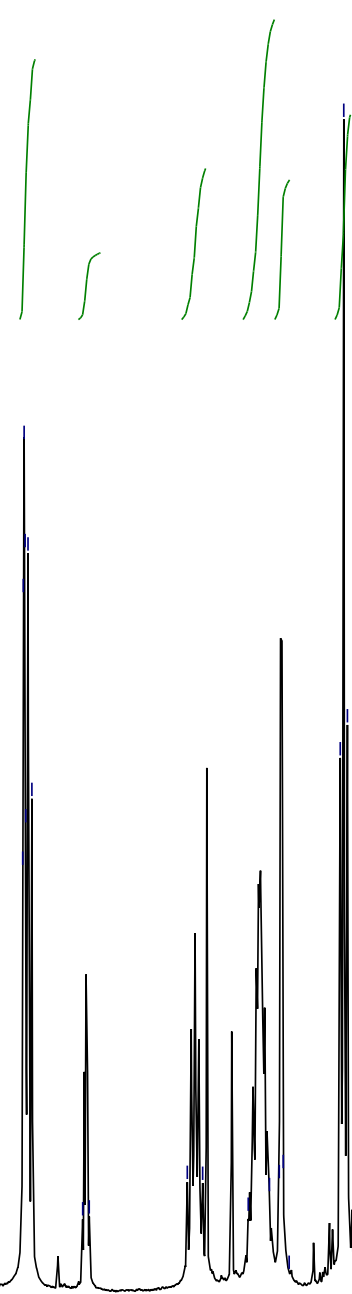

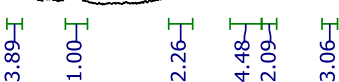

$0.5 \quad 10.0$

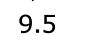

9.0

8.5

8.0
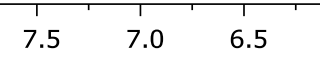

6.0

$5.5 \quad 5.0$

(ppm) 


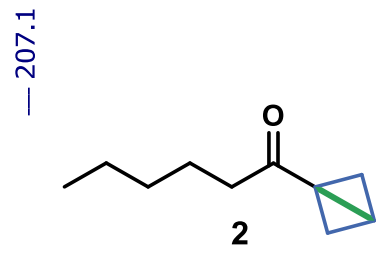

$101 \mathrm{MHz}{ }^{13} \mathrm{C}$ NMR Spectrum of compound $\mathbf{2}$ (recorded in $\mathrm{CDCl}_{3}$ )

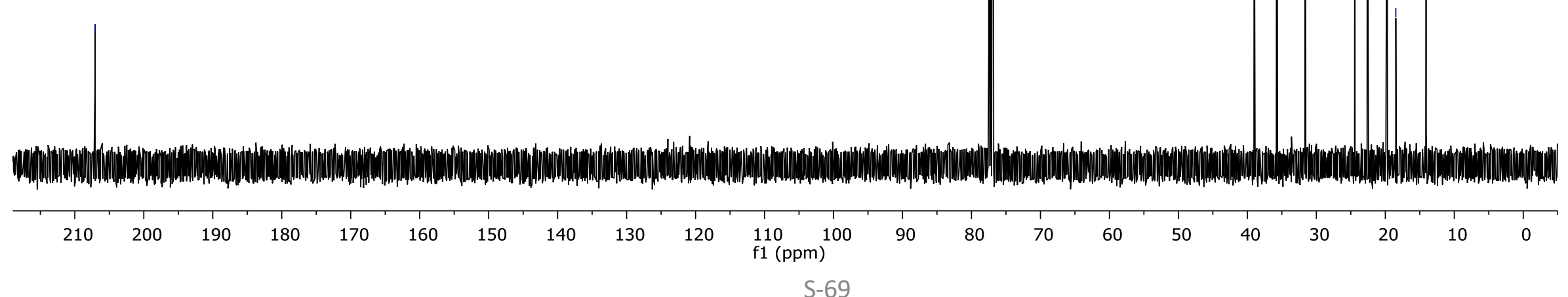




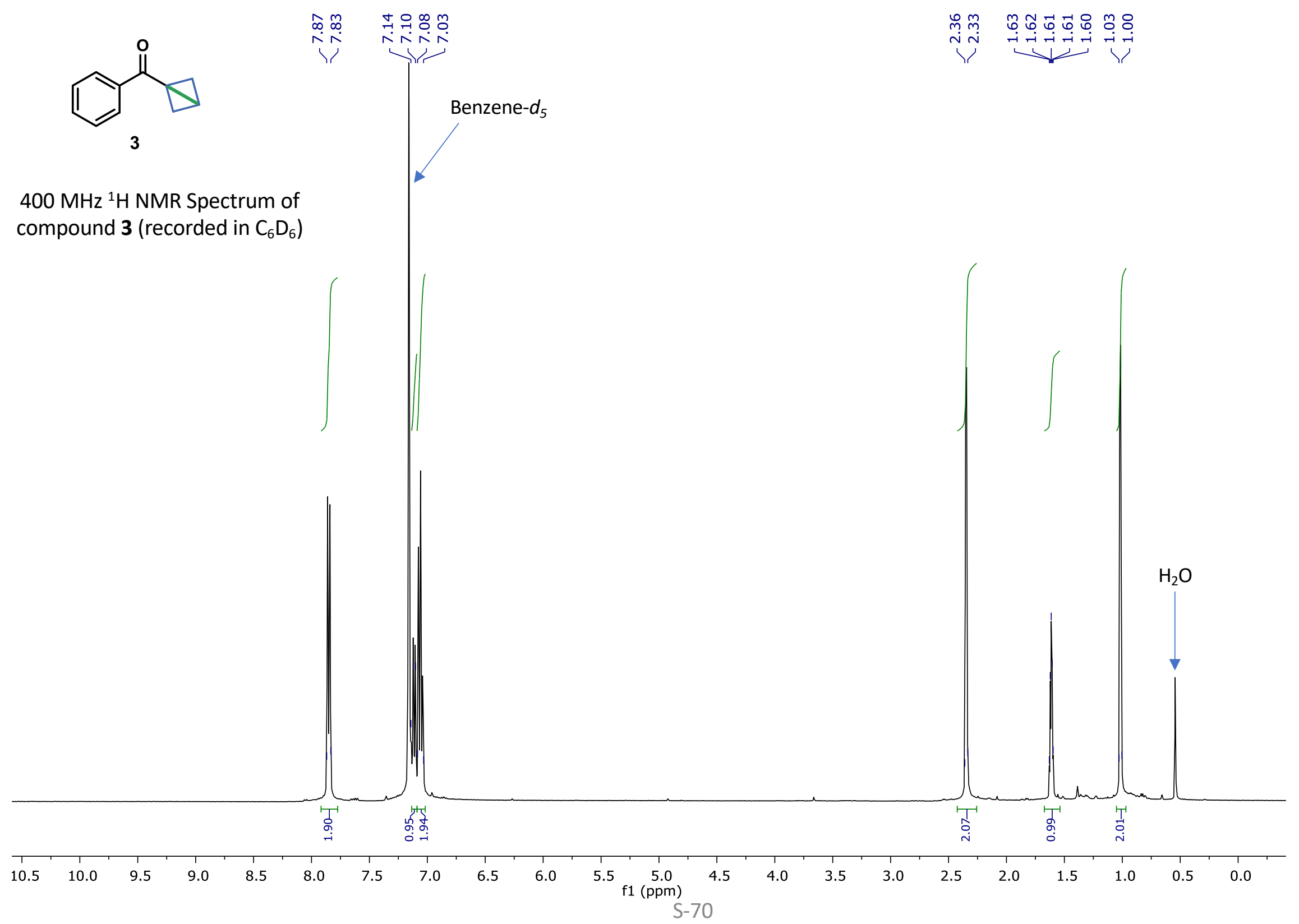




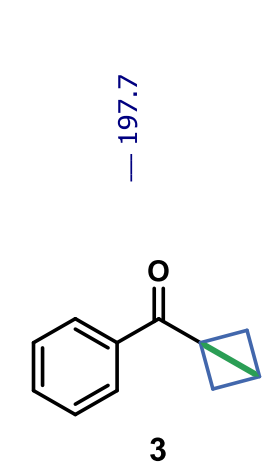

$101 \mathrm{MHz}{ }^{13} \mathrm{C}$ NMR Spectrum of compound 3 (recorded in $\mathrm{C}_{6} \mathrm{D}_{6}$ )

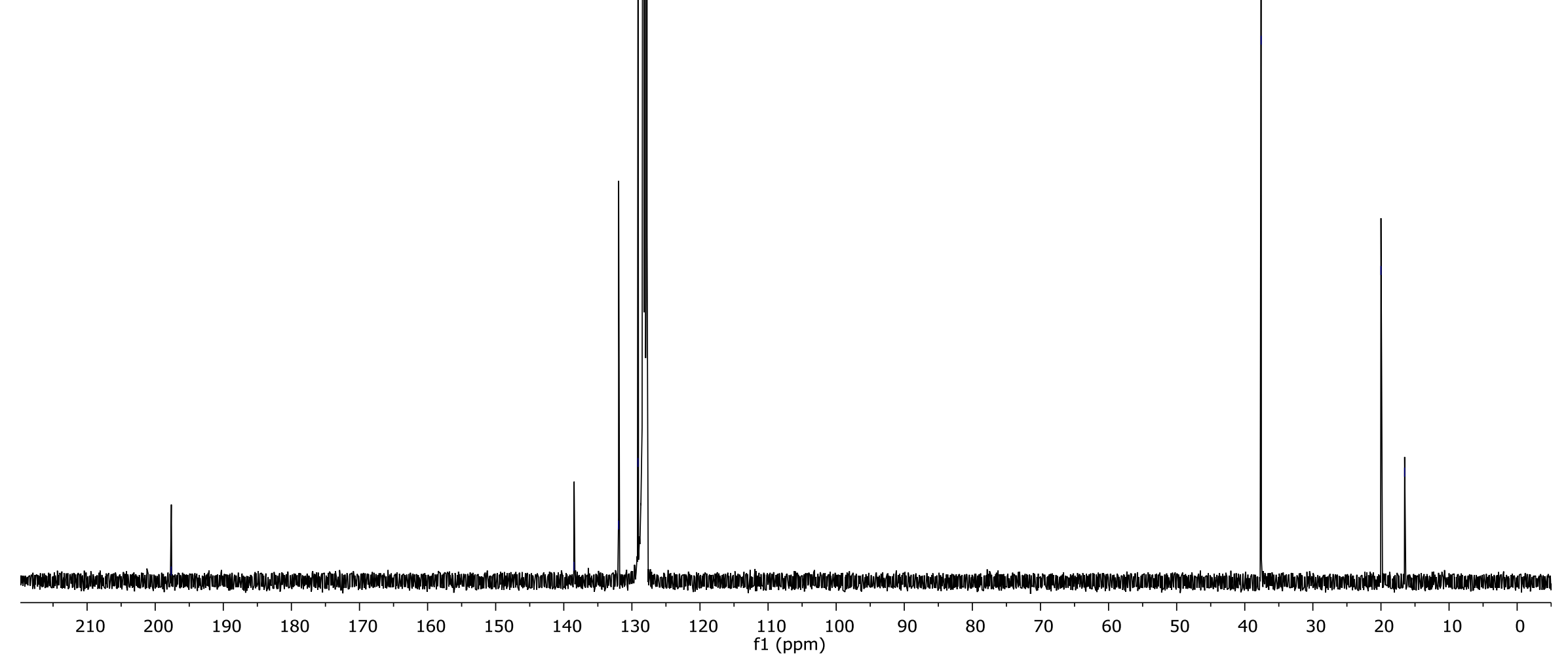



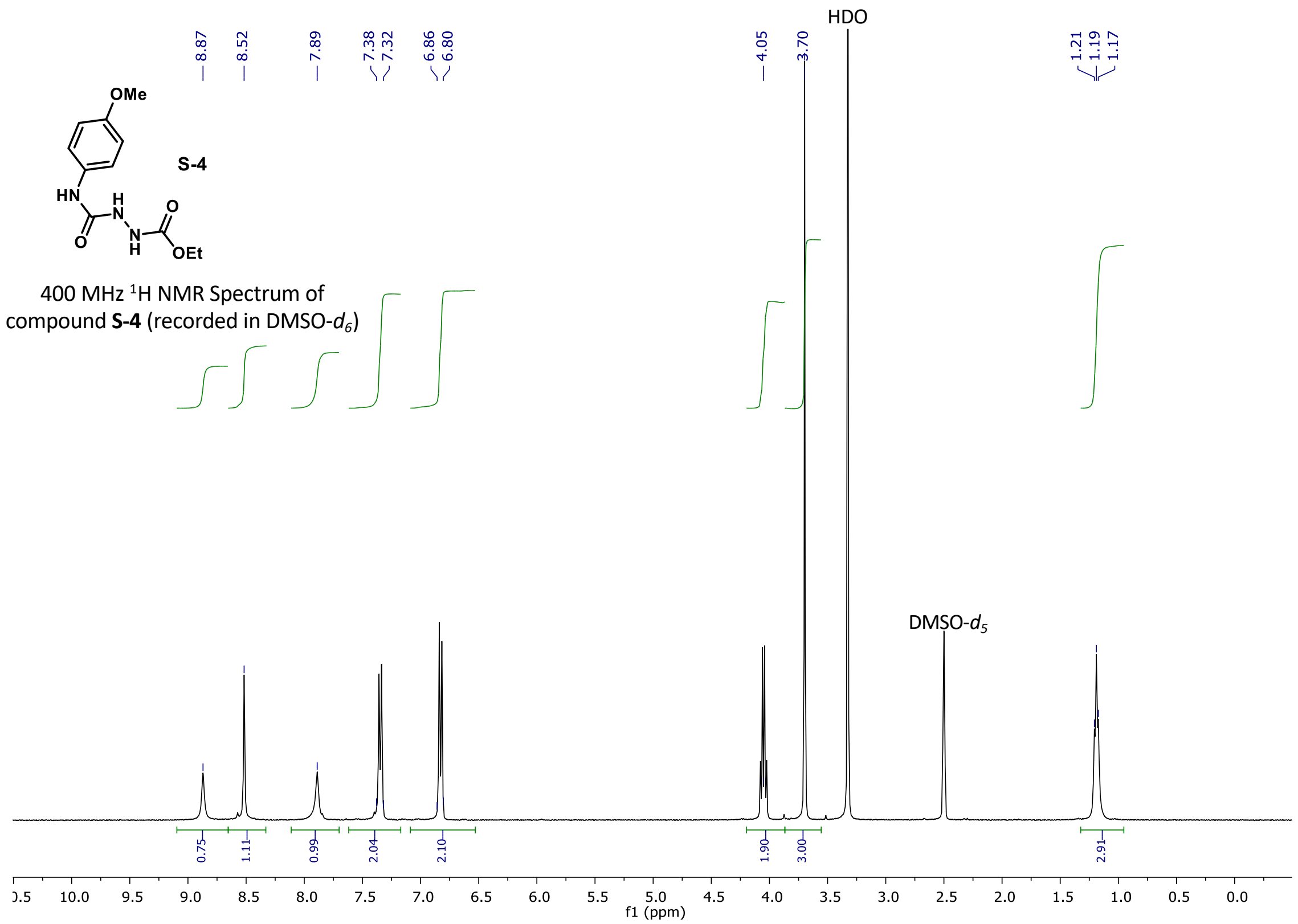

S-72 


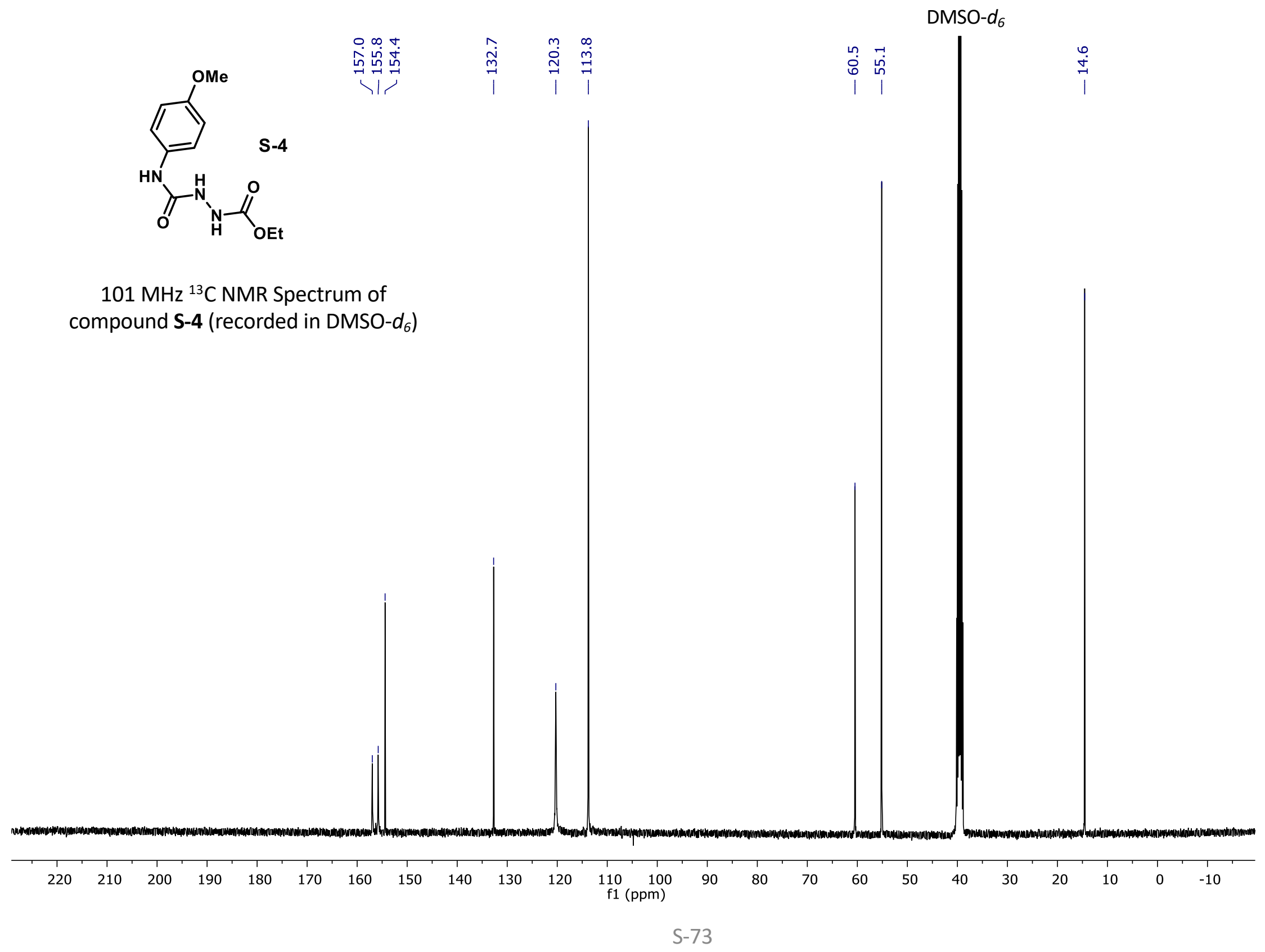




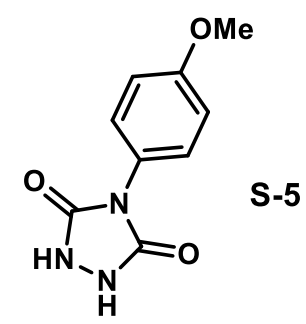

旁

$400 \mathrm{MHz}{ }^{1} \mathrm{H}$ NMR Spectrum of compound S-5 (recorded in DMSO- $d_{6}$ )

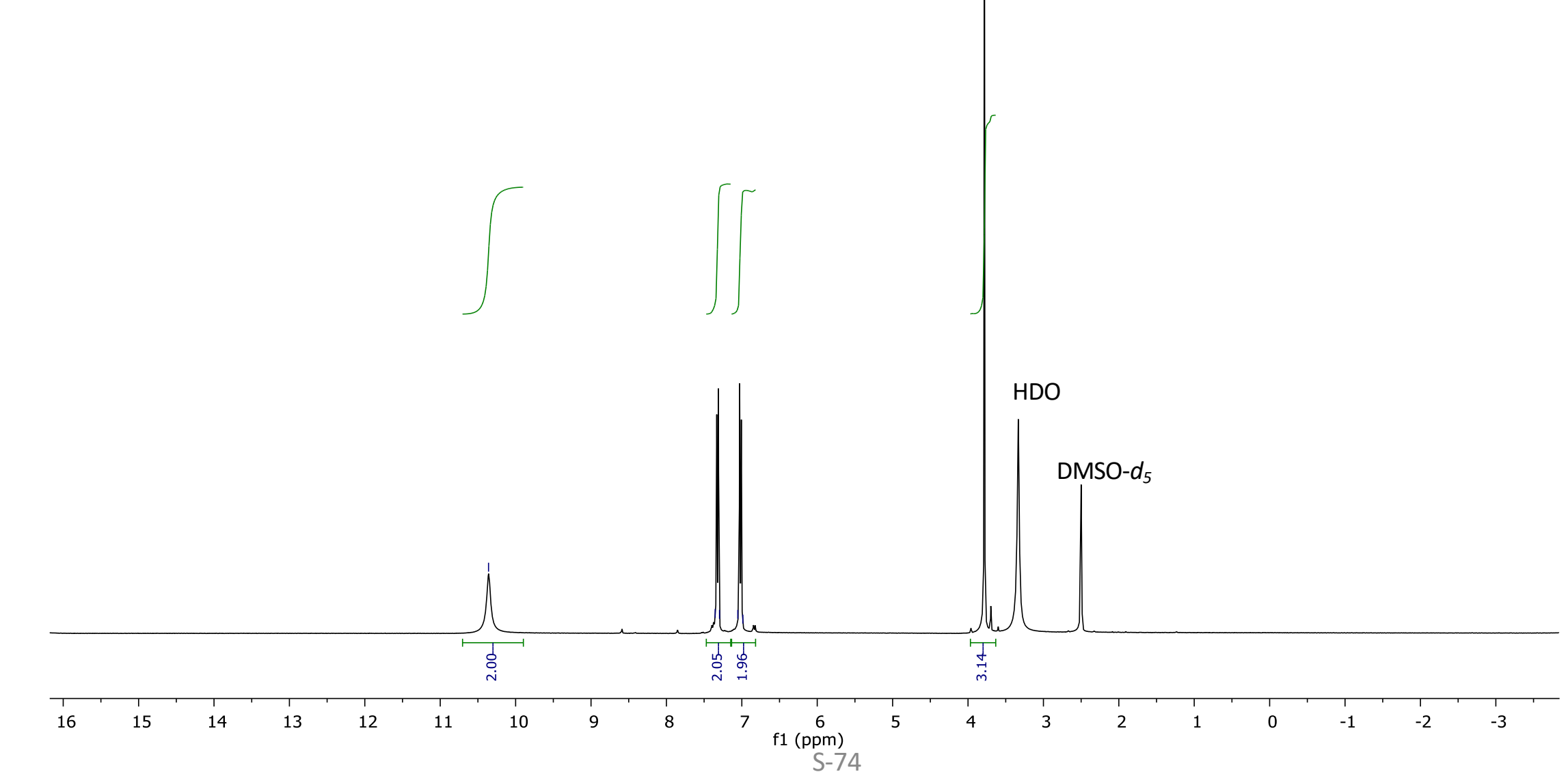


DMSO- $d_{6}$

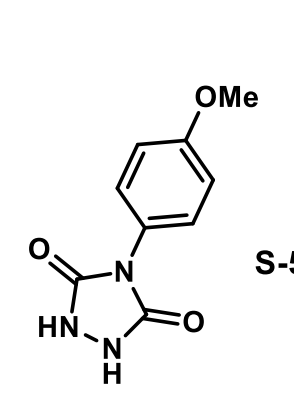

$101 \mathrm{MHz}{ }^{13} \mathrm{C}$ NMR Spectrum of compound S-5 (recorded in DMSO- $d_{6}$ )

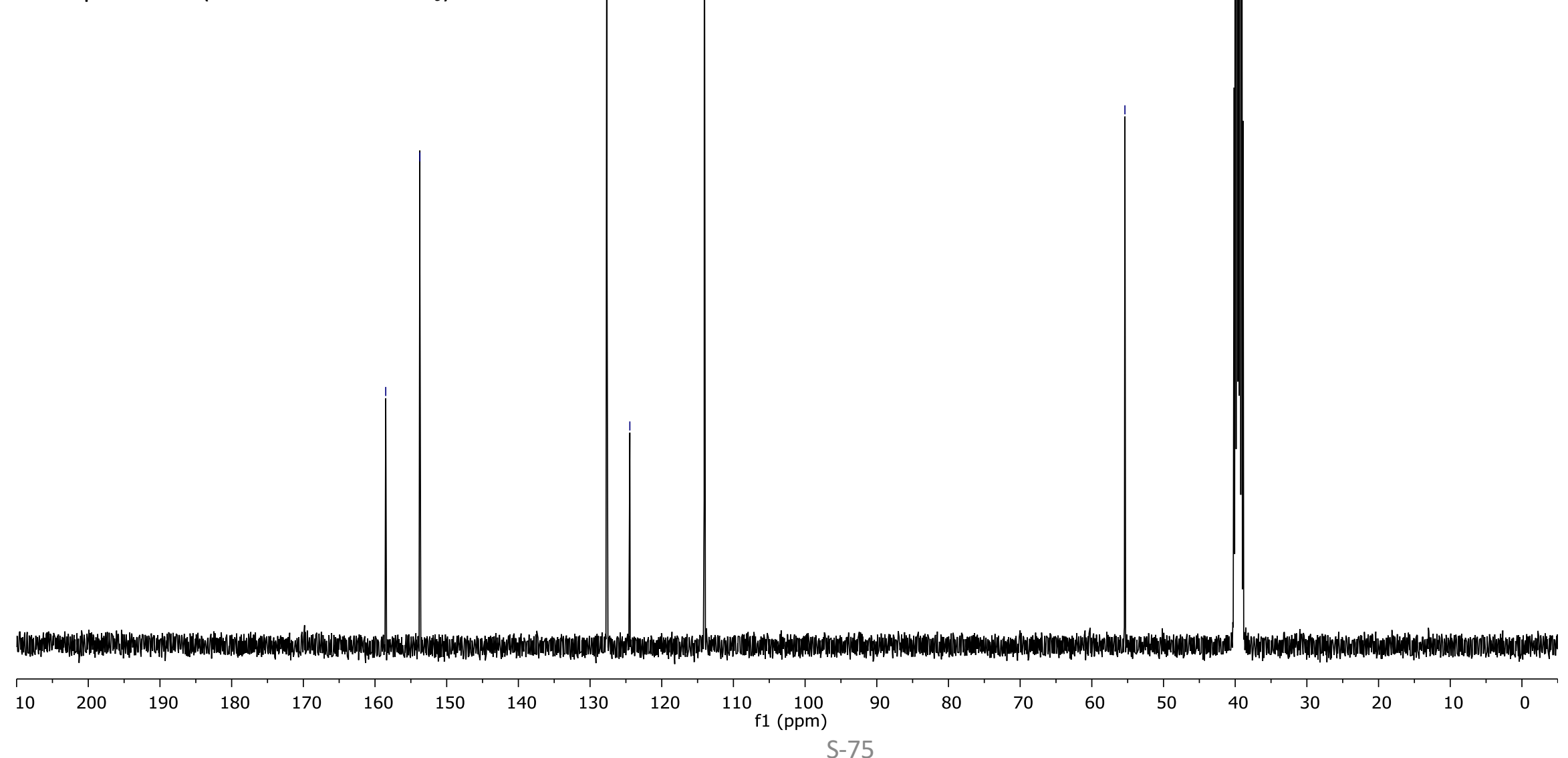




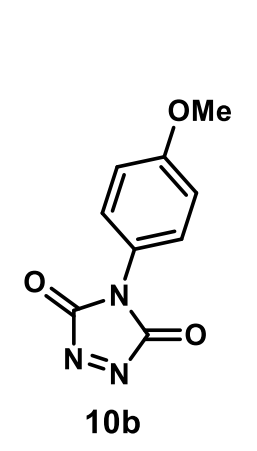

ำ

$\stackrel{\infty}{\infty}$

$400 \mathrm{MHz}{ }^{1} \mathrm{H}$ NMR Spectrum of

compound 10b (recorded in $\mathrm{CDCl}_{3}$ )

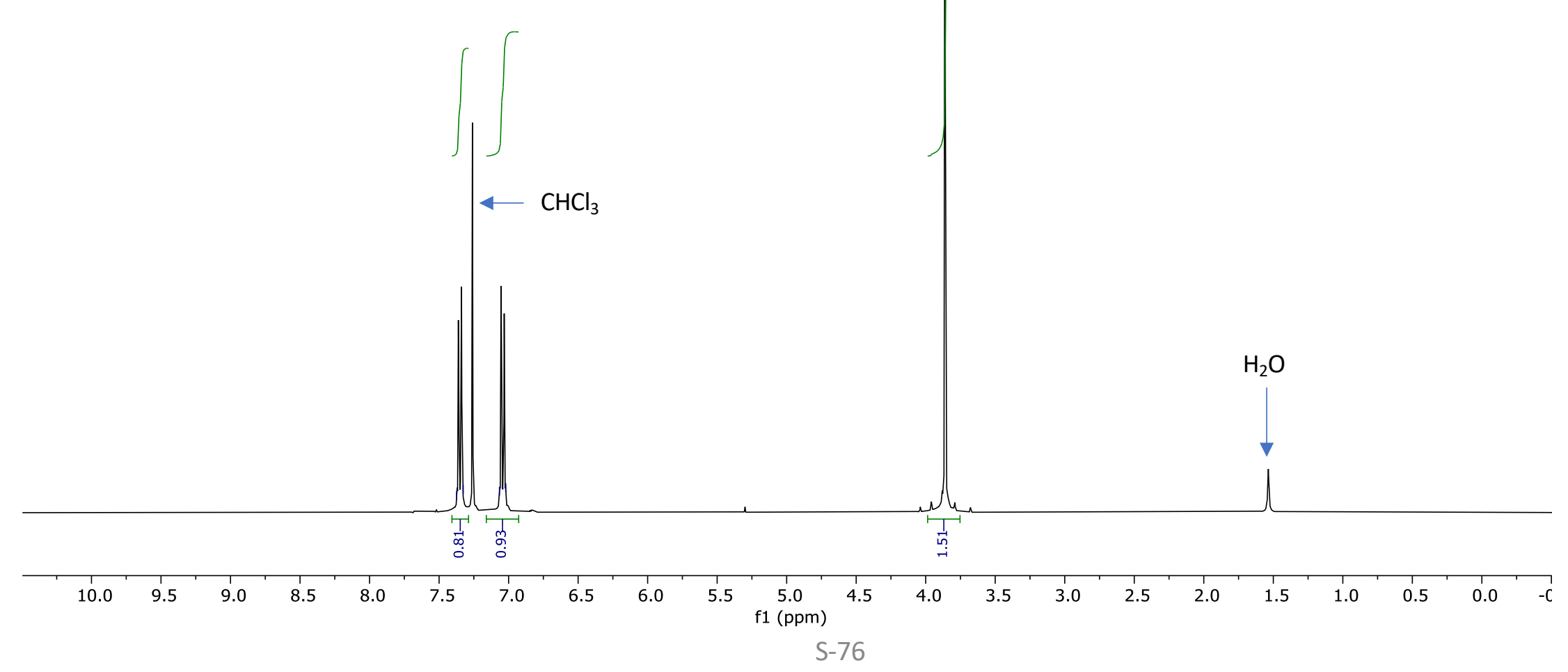




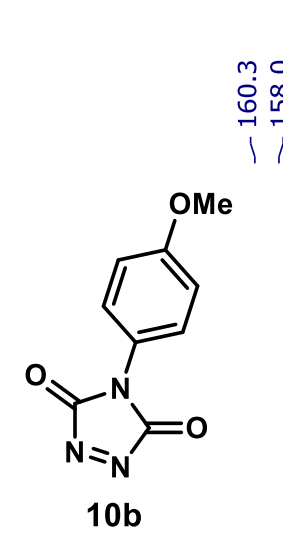

$101 \mathrm{MHz}{ }^{13} \mathrm{C}$ NMR Spectrum of compound $10 \mathrm{~b}$ (recorded in $\mathrm{CDCl}_{3}$ )

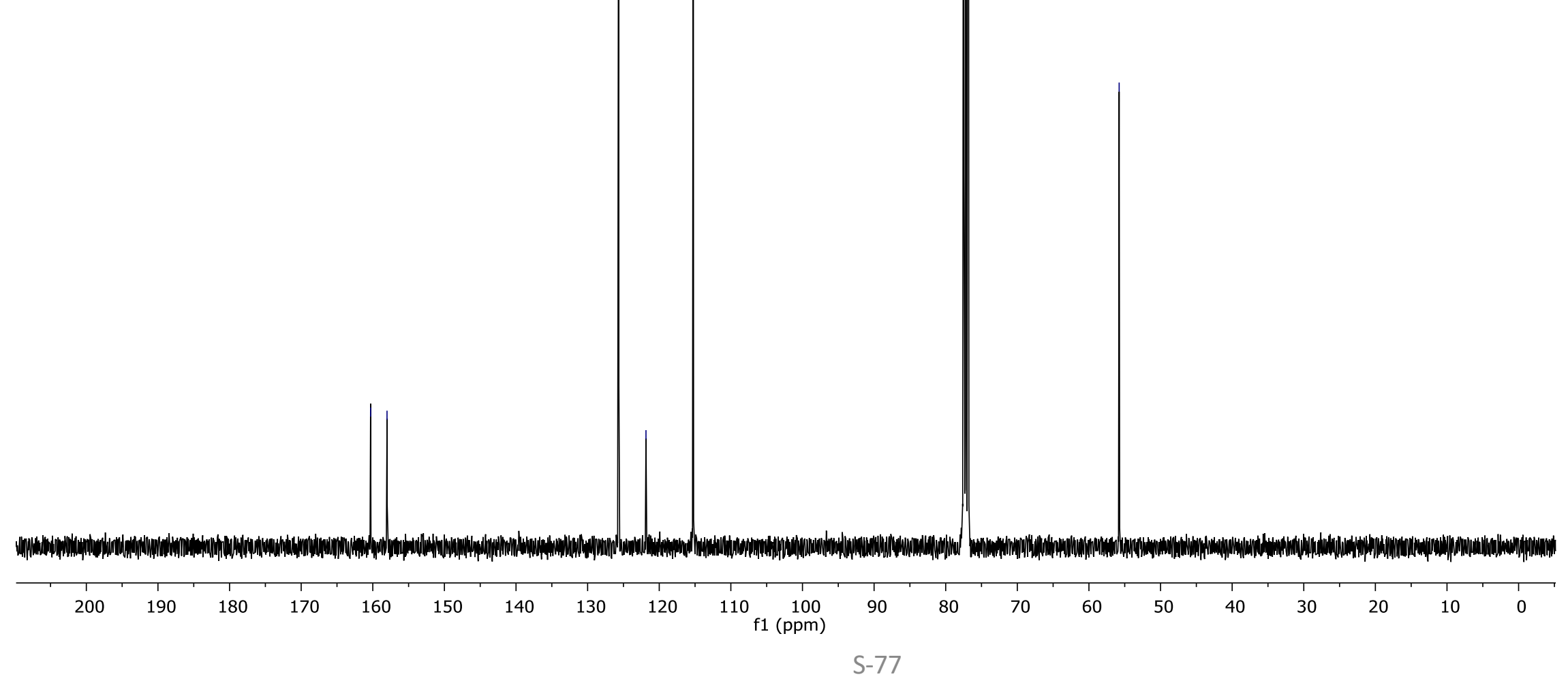




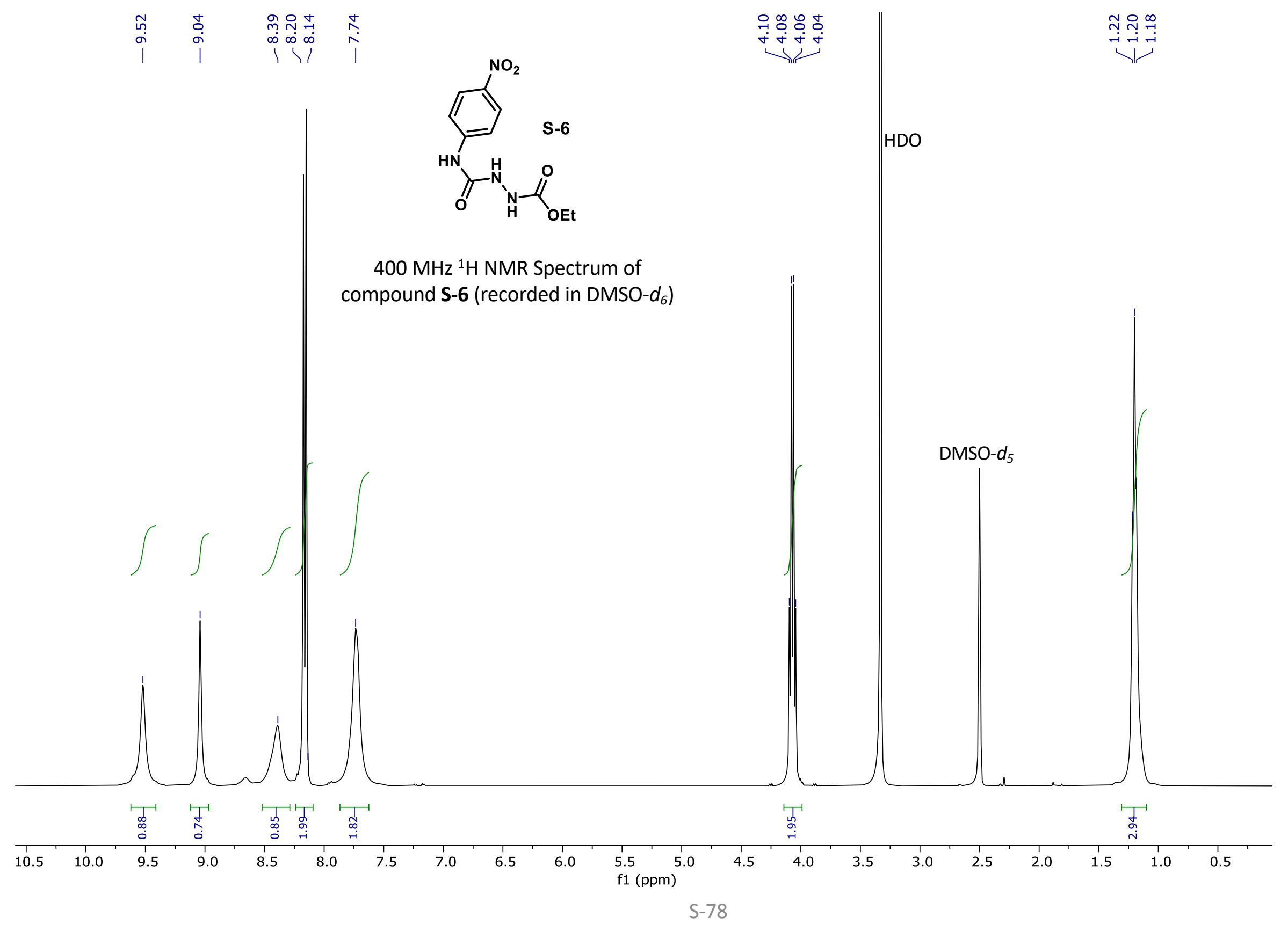




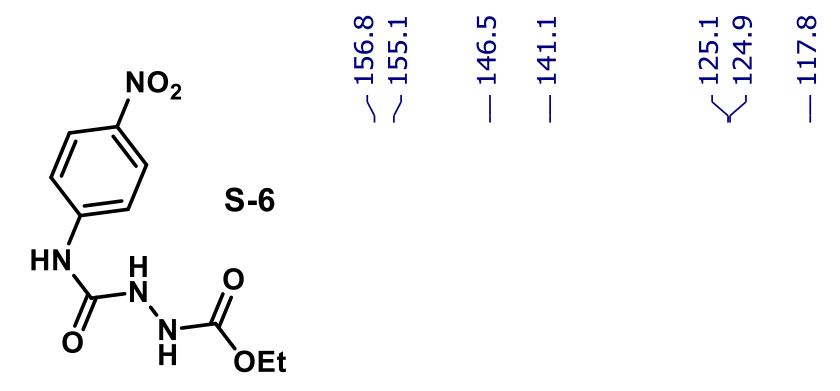

$400 \mathrm{MHz}{ }^{1} \mathrm{H}$ NMR Spectrum of

compound S-6 (recorded in DMSO- $d_{6}$ )

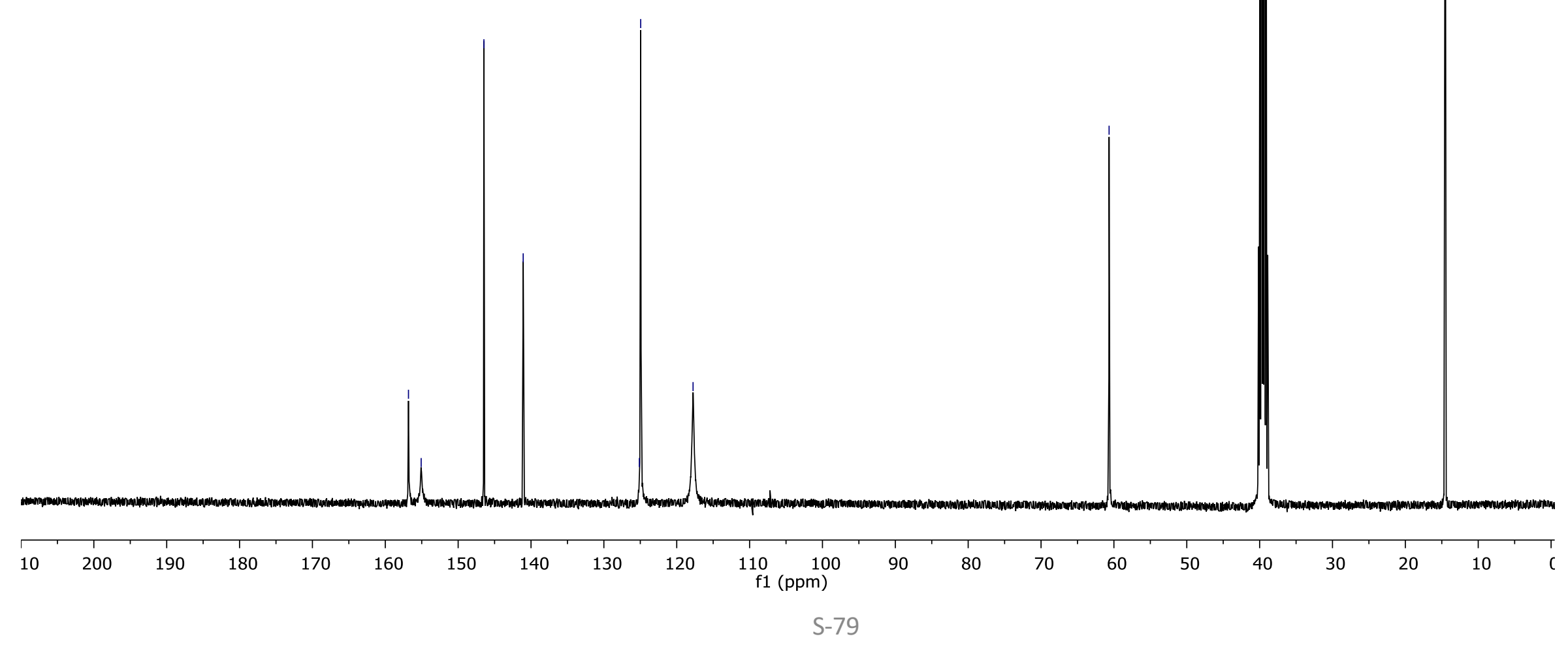




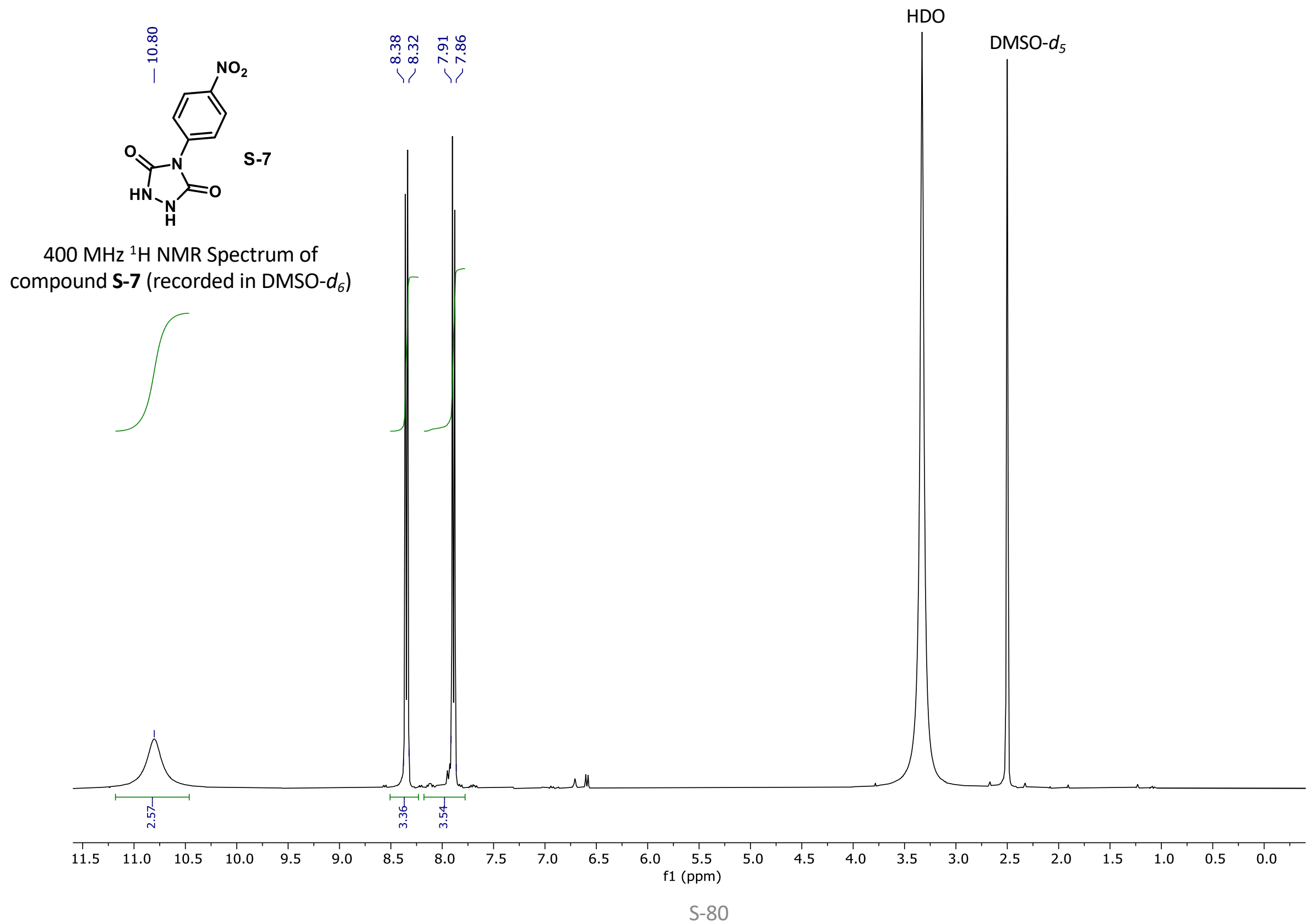




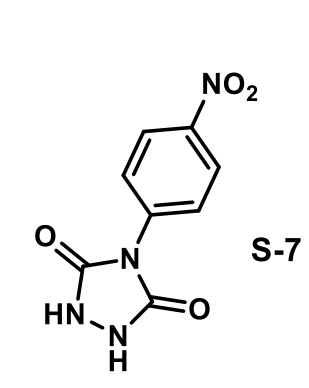

$101 \mathrm{MHz}{ }^{13} \mathrm{C}$ NMR Spectrum of compound S-7 (recorded in DMSO- $d_{6}$ )

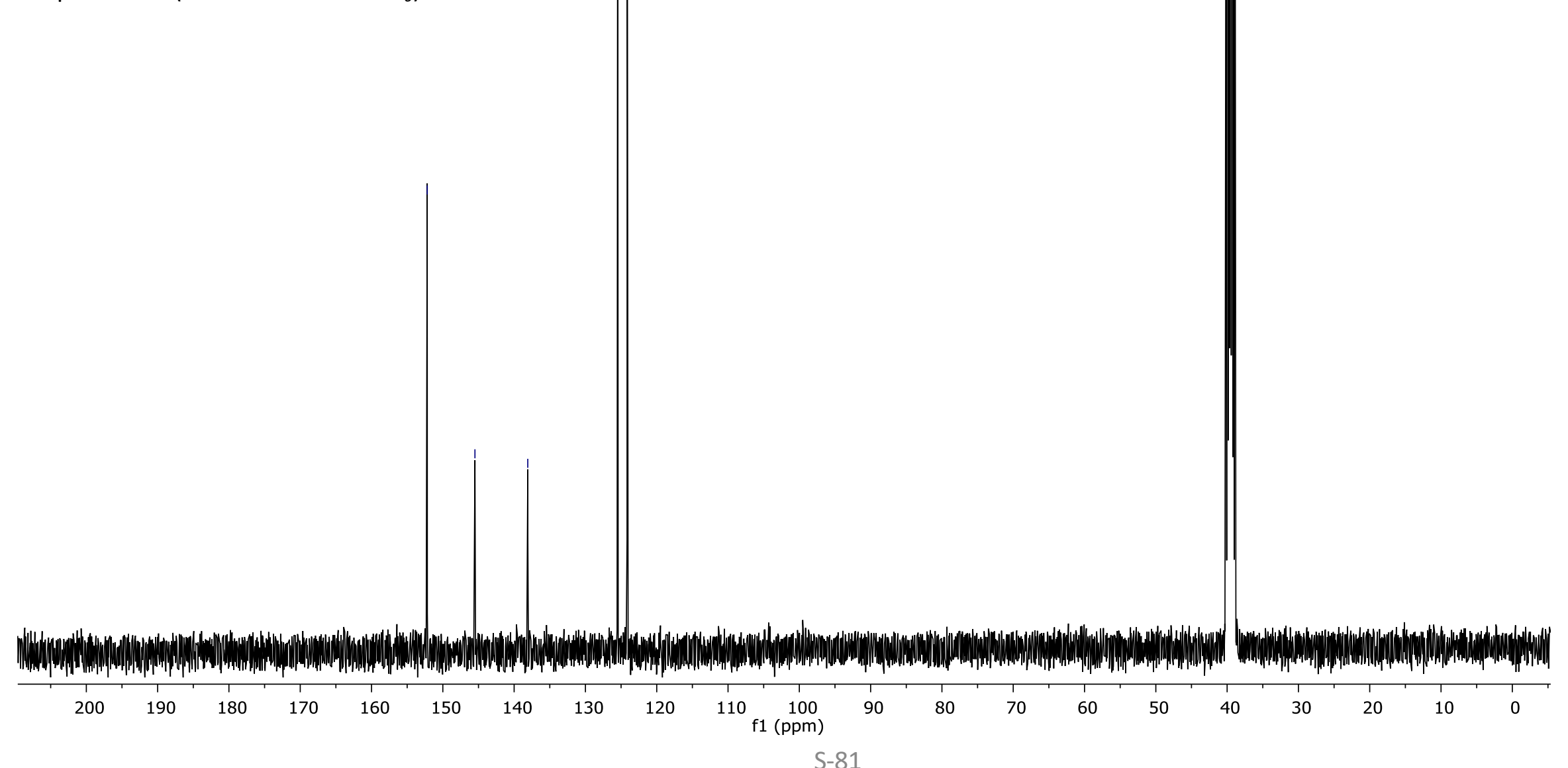




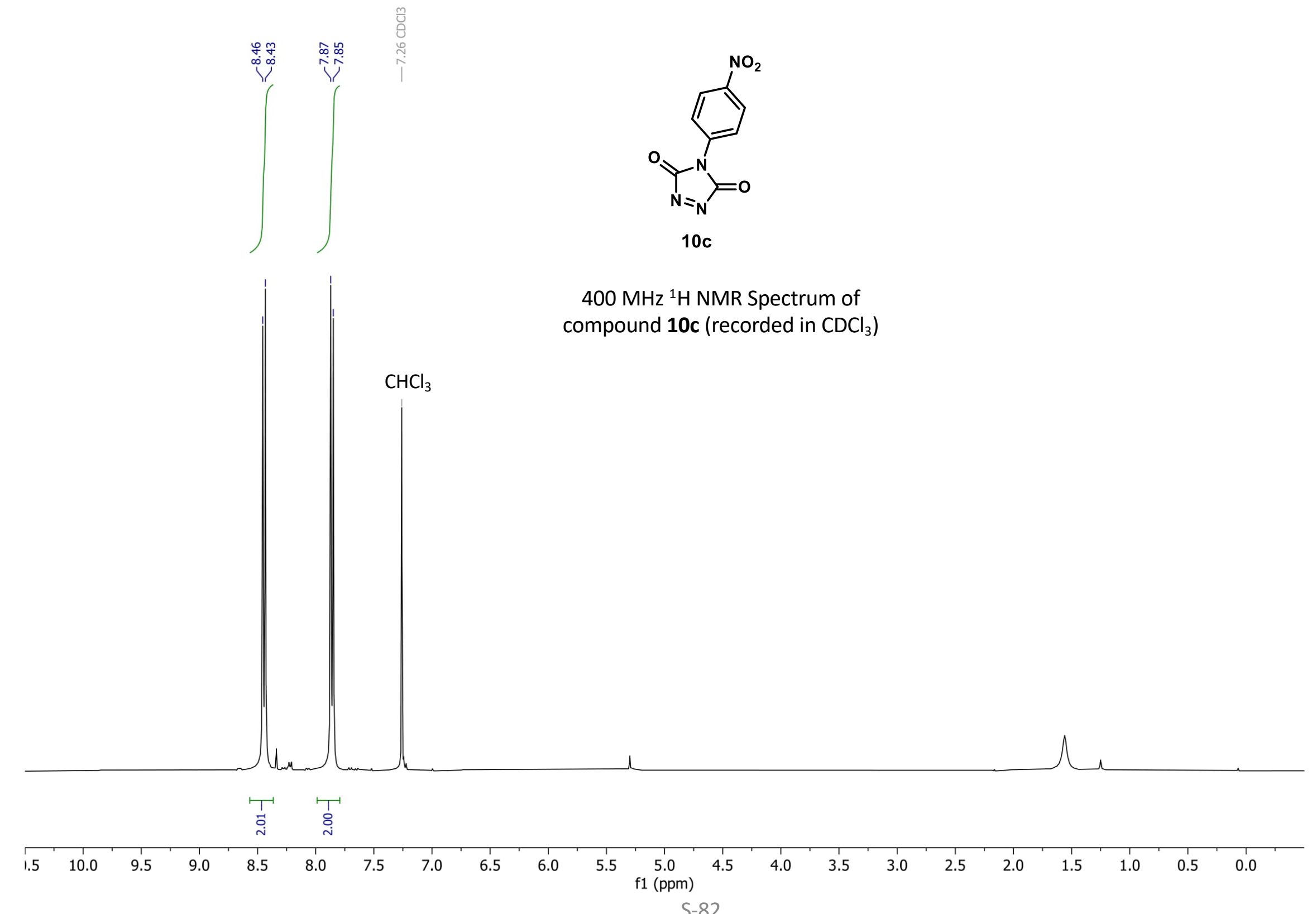




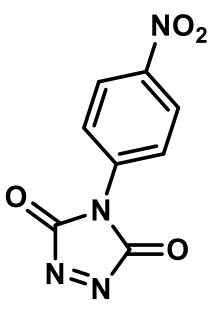

10c

$101 \mathrm{MHz}{ }^{13} \mathrm{C}$ NMR Spectrum of compound $10 \mathrm{c}$ (recorded in $\mathrm{CDCl}_{3}$ )

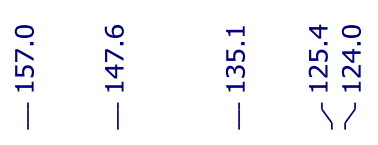

$\mathrm{CDCl}_{3}$

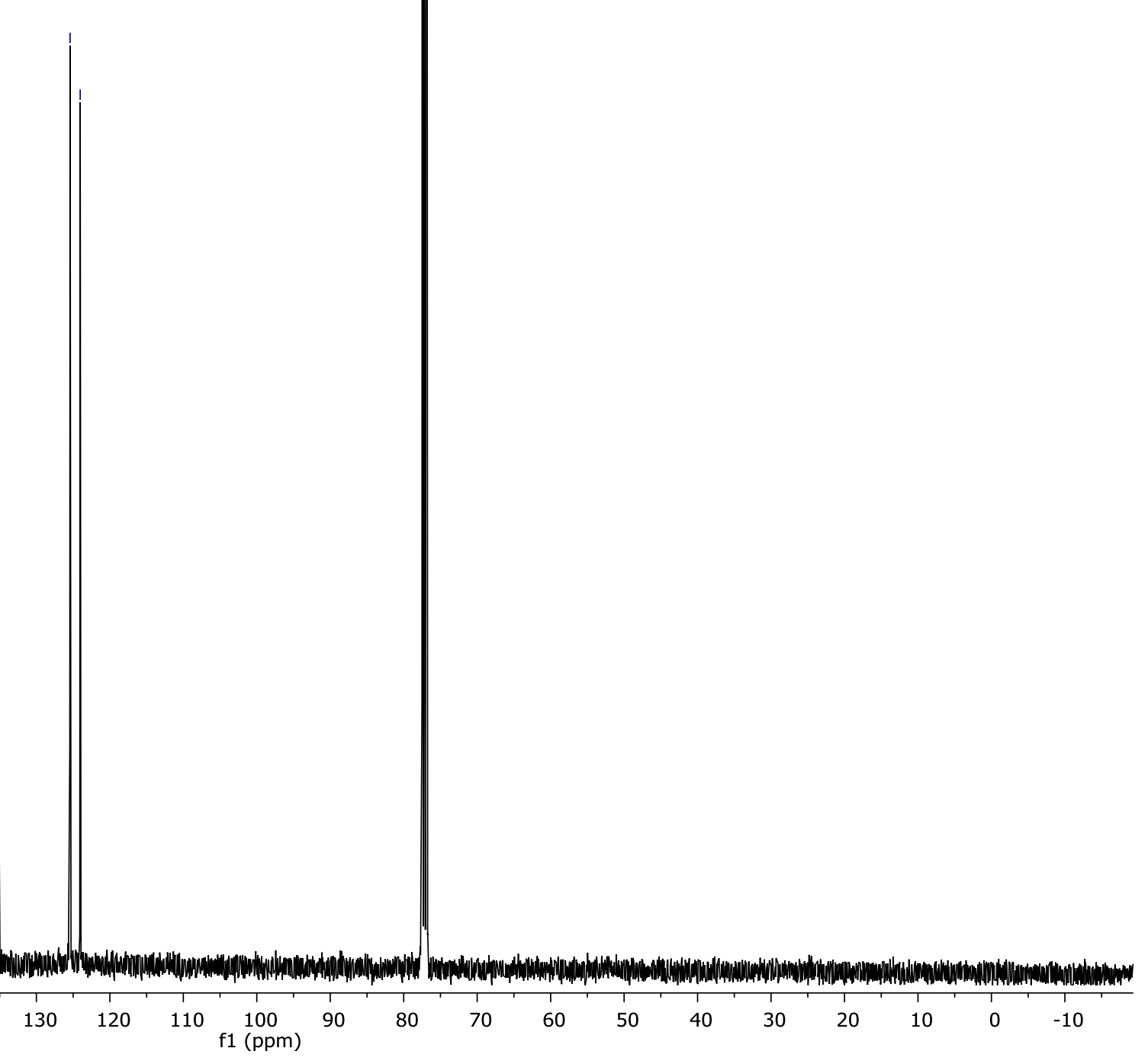

S-83 


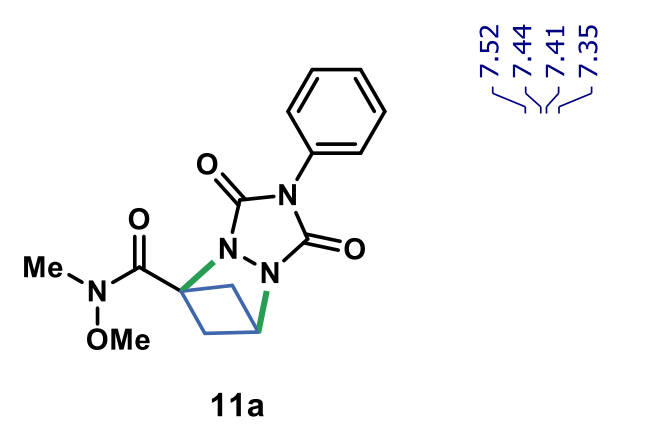

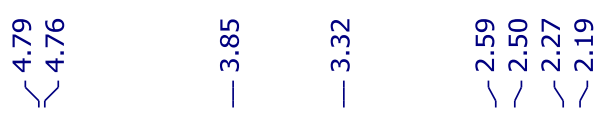

$400 \mathrm{MHz}{ }^{1} \mathrm{H}$ NMR Spectrum of

compound 11a (recorded in $\mathrm{CDCl}_{3}$ ) $\mathrm{CHCl}_{3}$

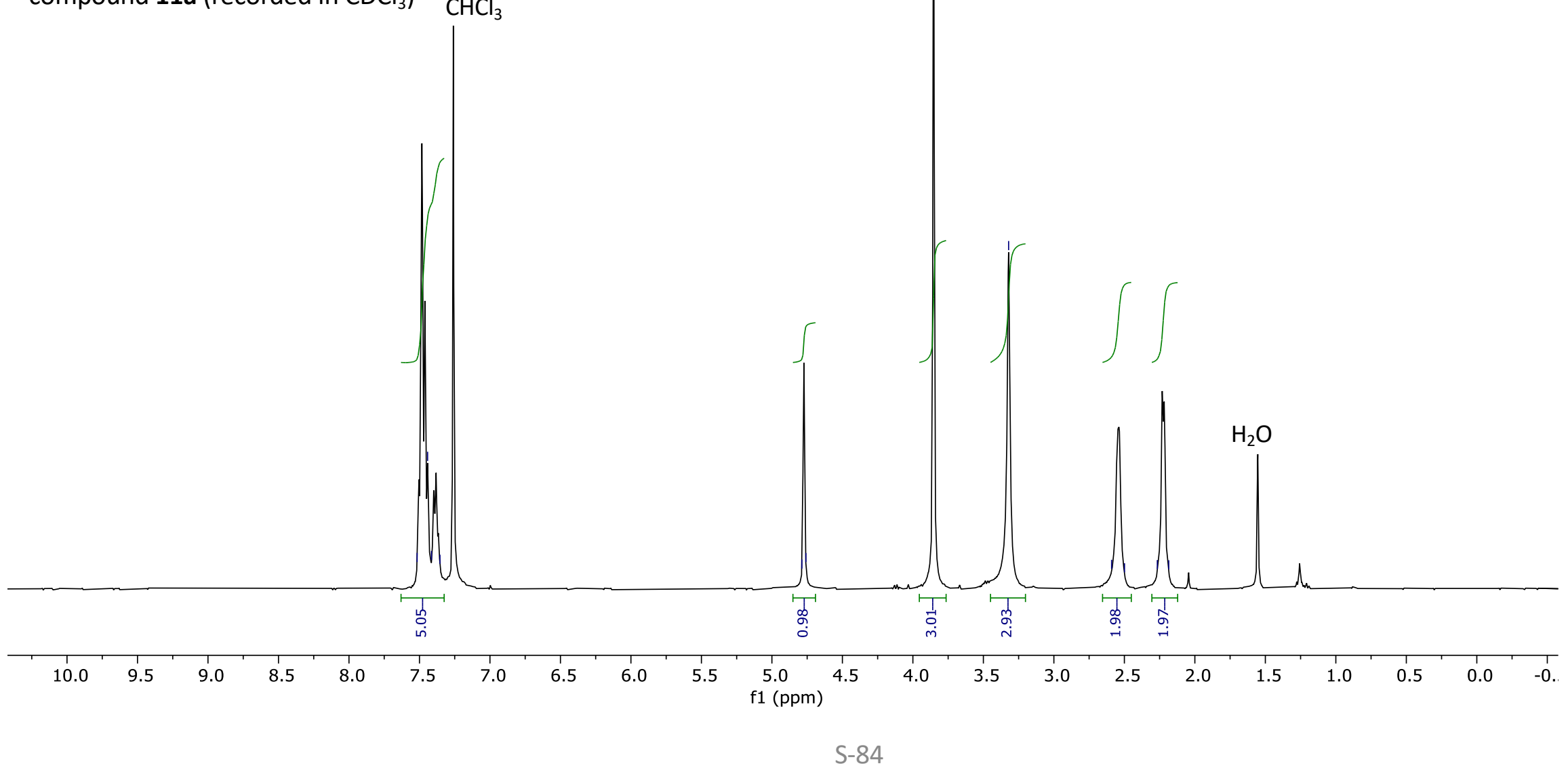




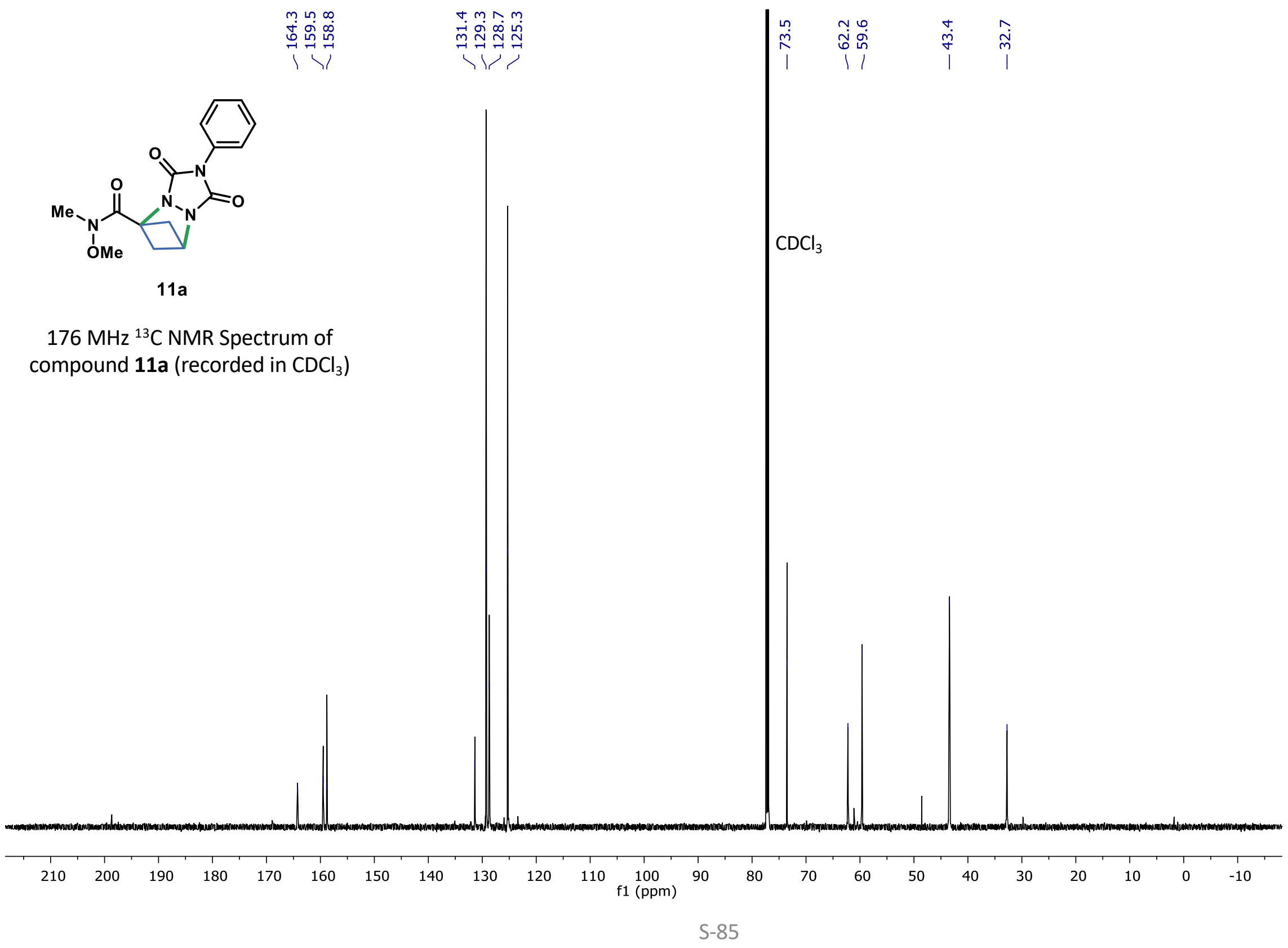




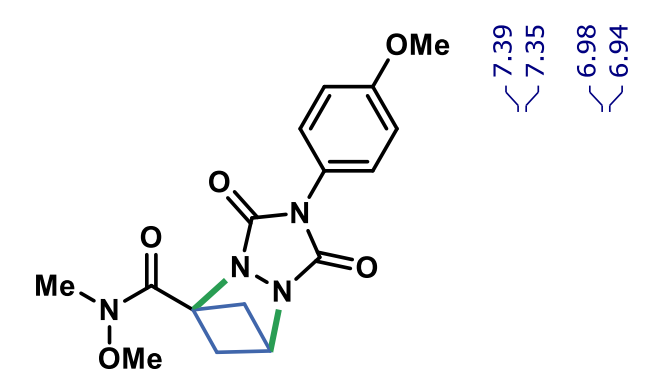

$11 b$

$600 \mathrm{MHz}{ }^{1} \mathrm{H}$ NMR Spectrum of compound $\mathbf{1 1 b}$ (recorded in $\mathrm{CDCl}_{3}$ )

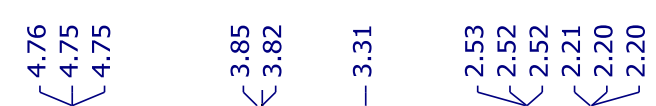

ॠ $Y$ Y $\psi$ 

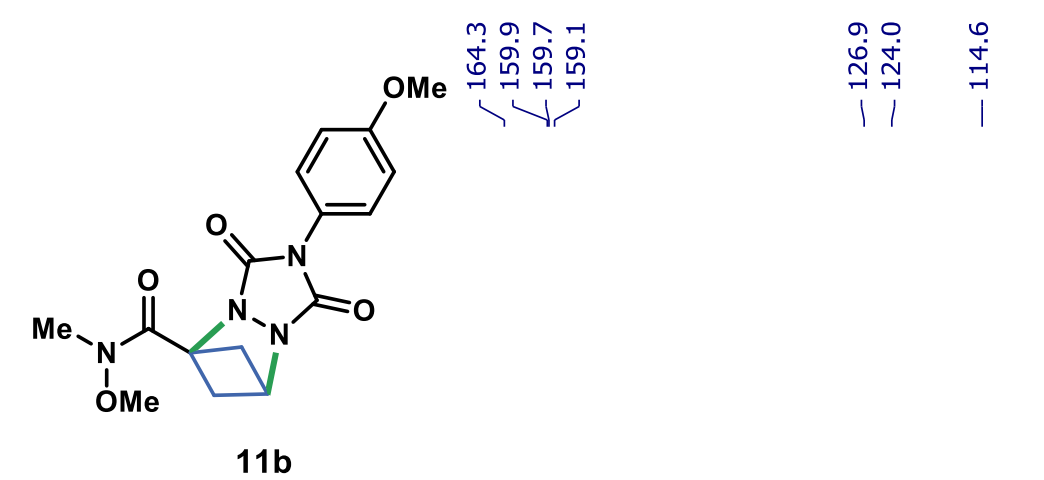

$151 \mathrm{MHz}{ }^{13} \mathrm{C}$ NMR Spectrum of compound 11b (recorded in $\mathrm{CDCl}_{3}$ )

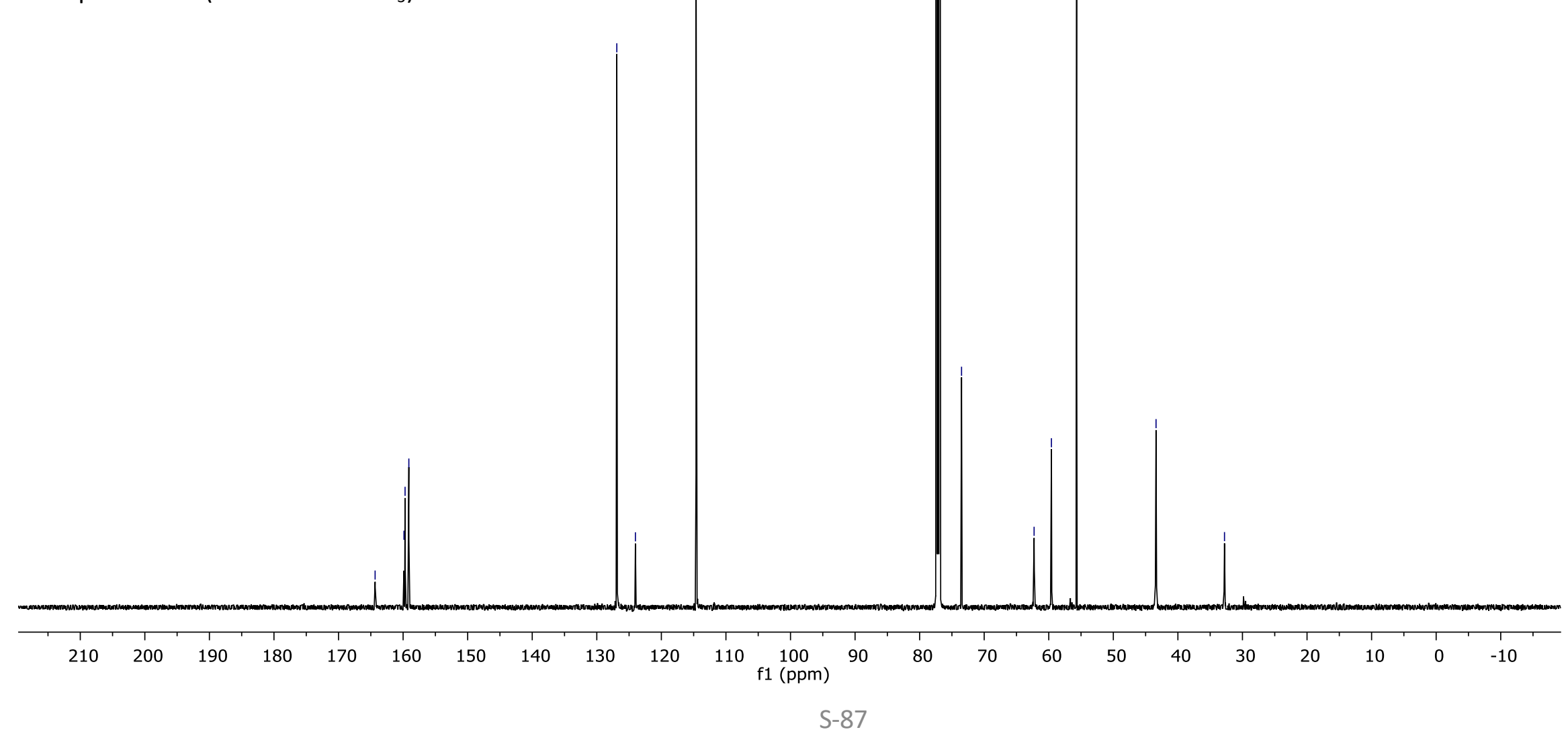




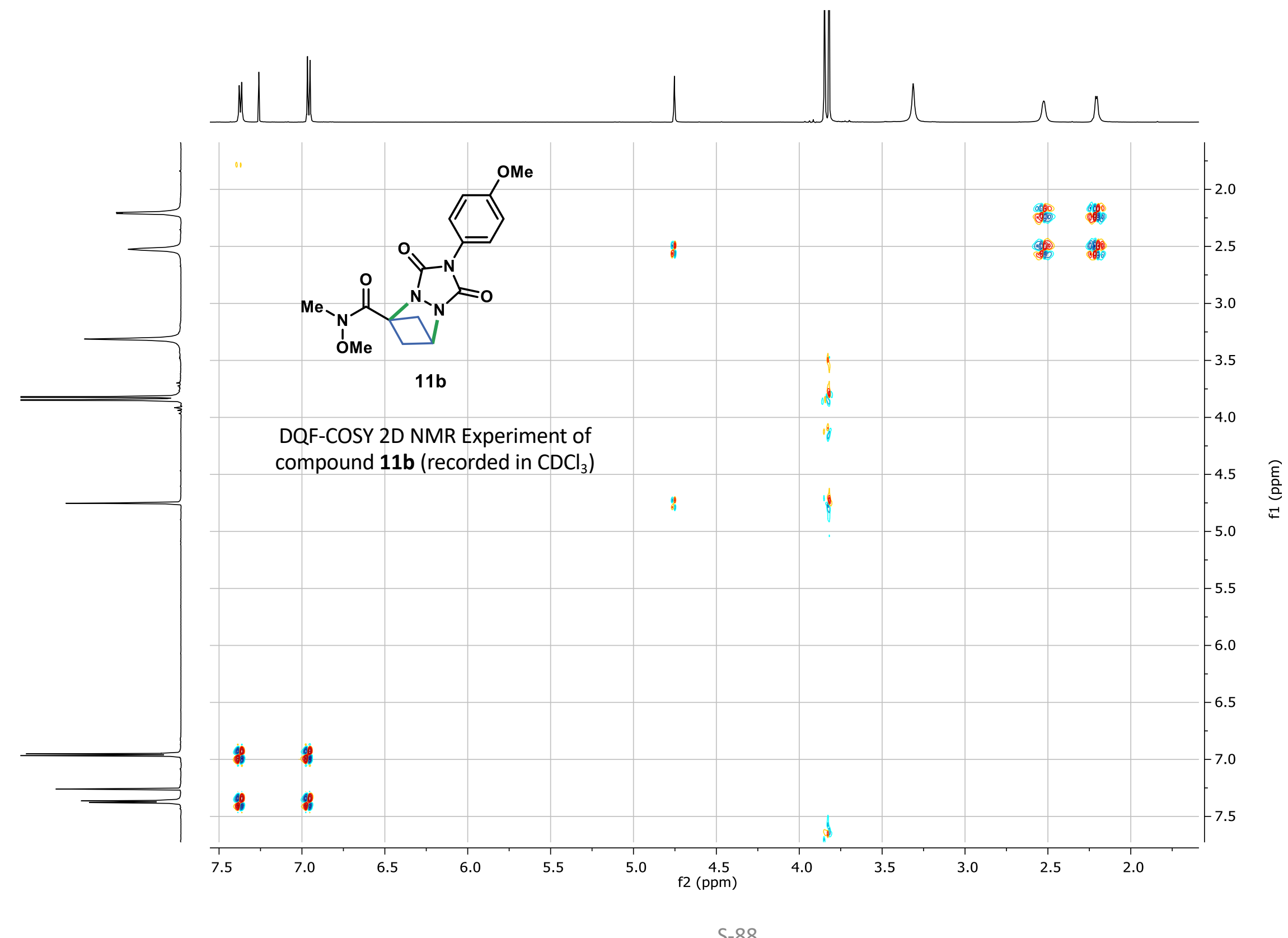




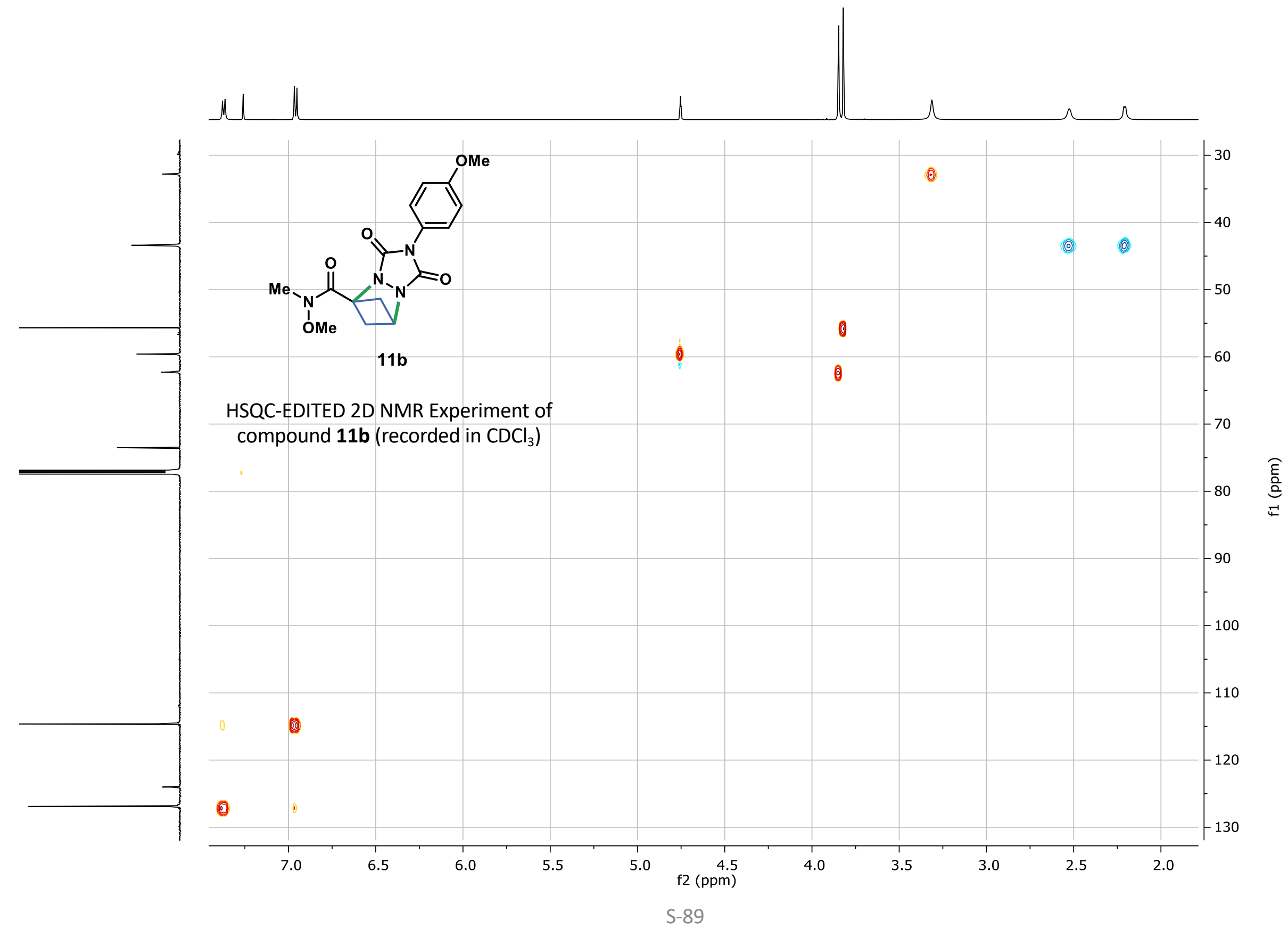




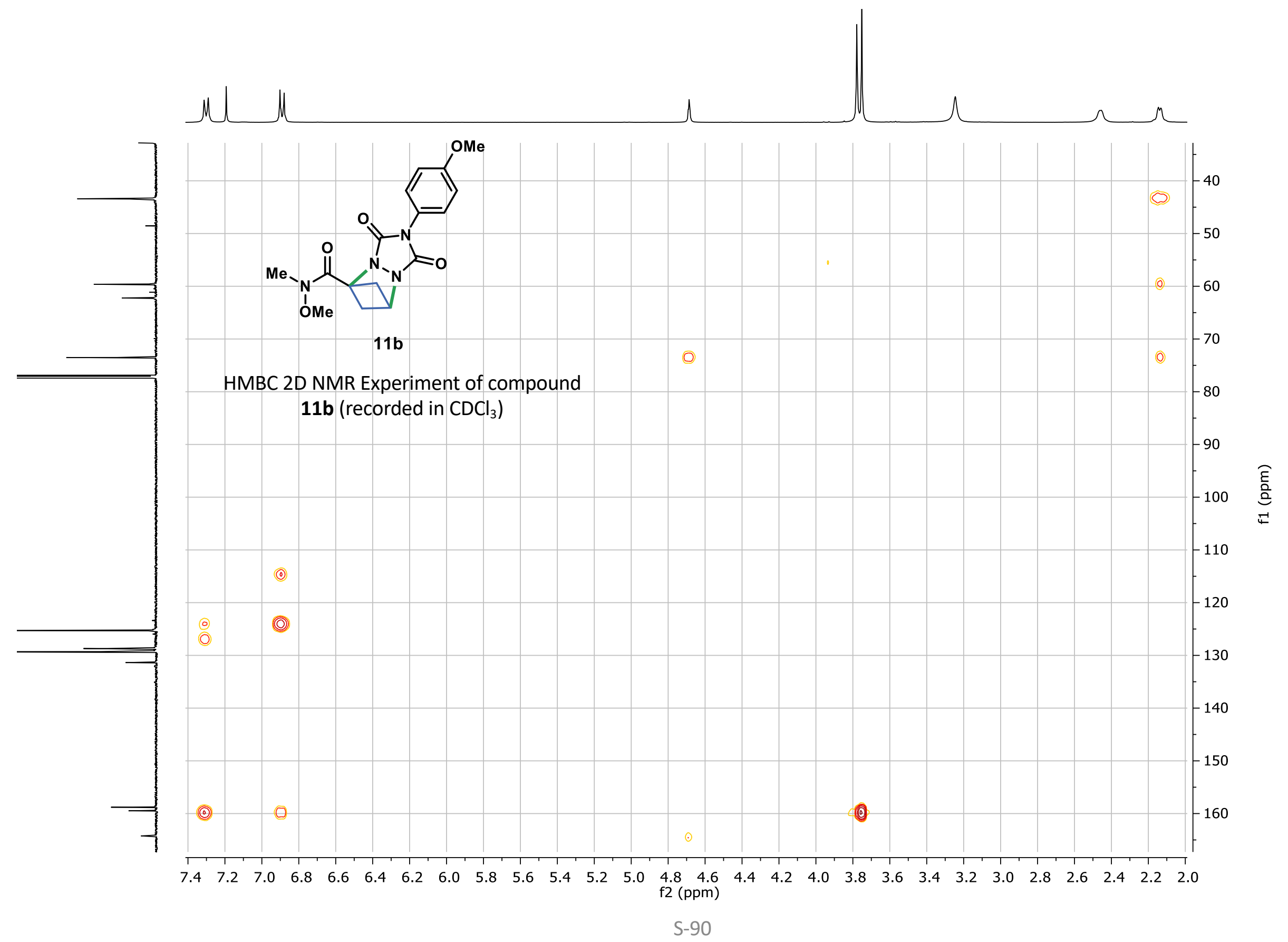




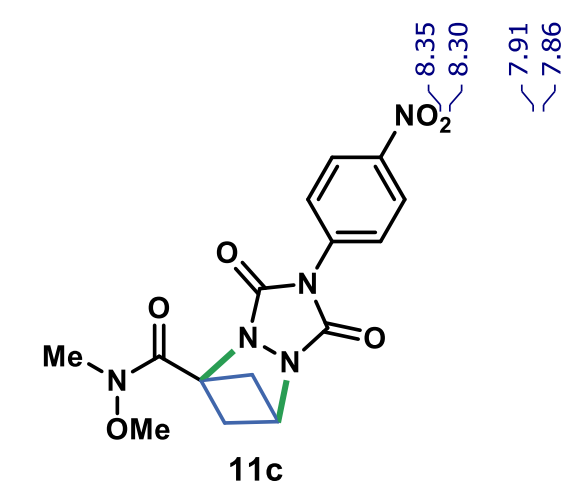

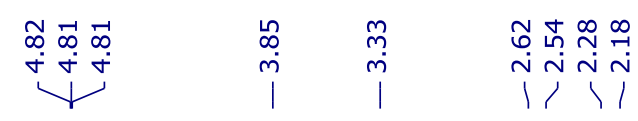

$400 \mathrm{MHz}{ }^{1} \mathrm{H}$ NMR Spectrum of compound 11c (recorded in $\mathrm{CDCl}_{3}$ )

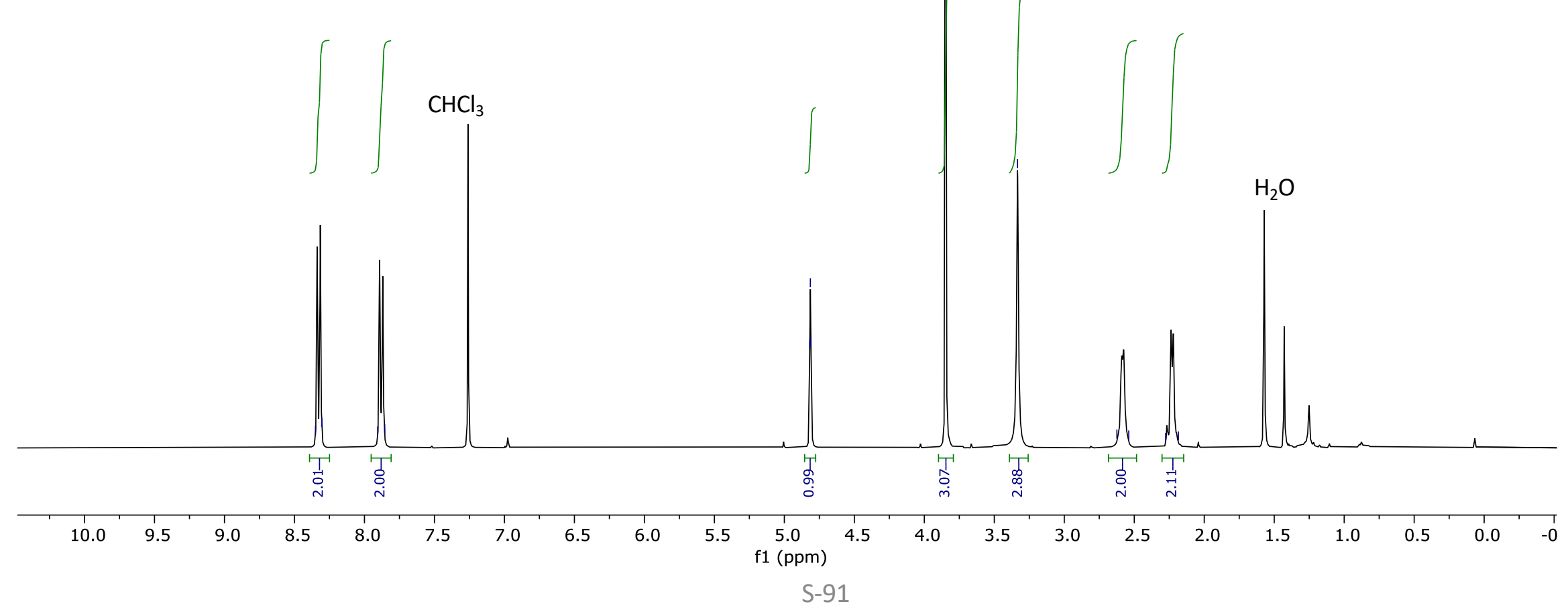




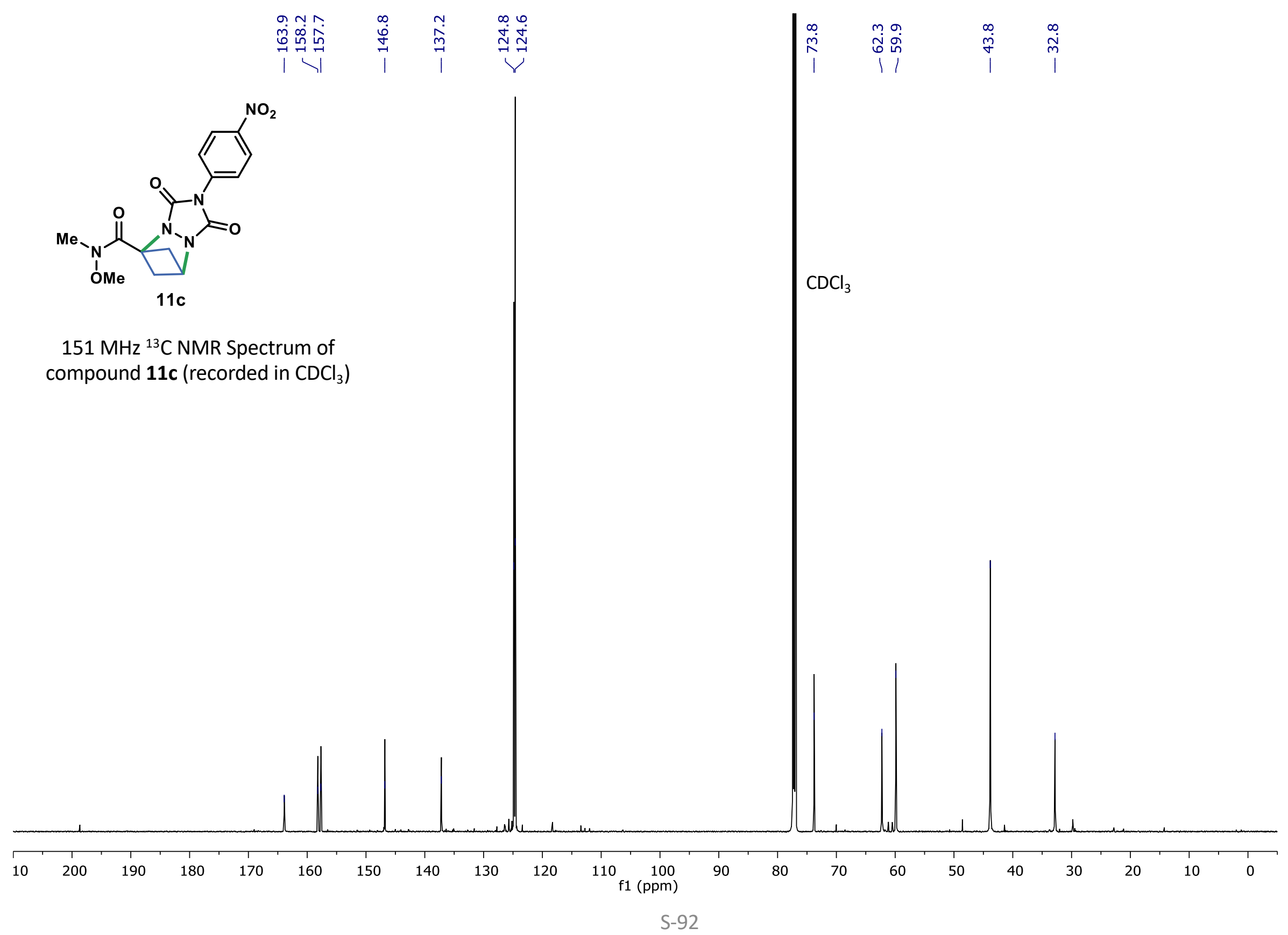




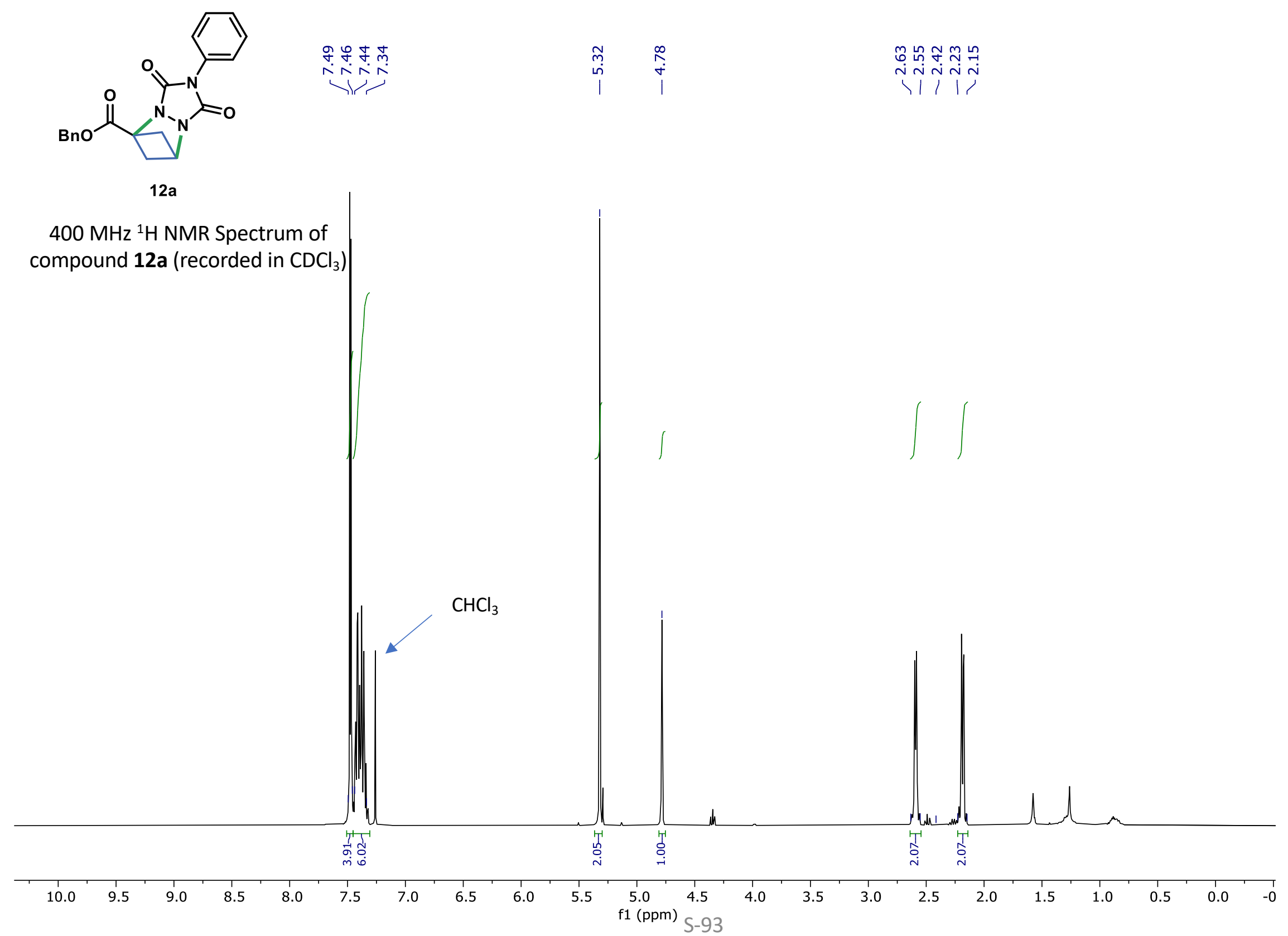




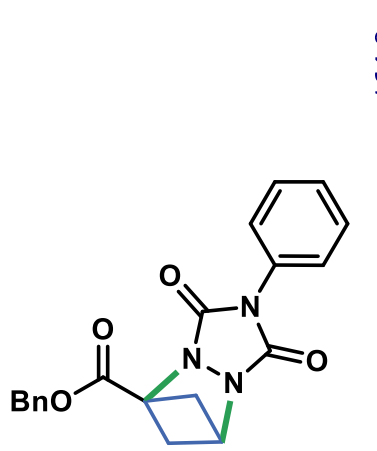

12a

$101 \mathrm{MHz}{ }^{13} \mathrm{C}$ NMR Spectrum of compound 12a (recorded in $\mathrm{CDCl}_{3}$ )

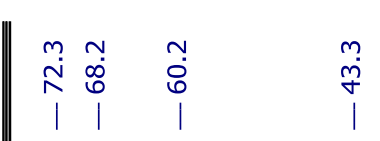

$\mathrm{CDCl}_{3}$

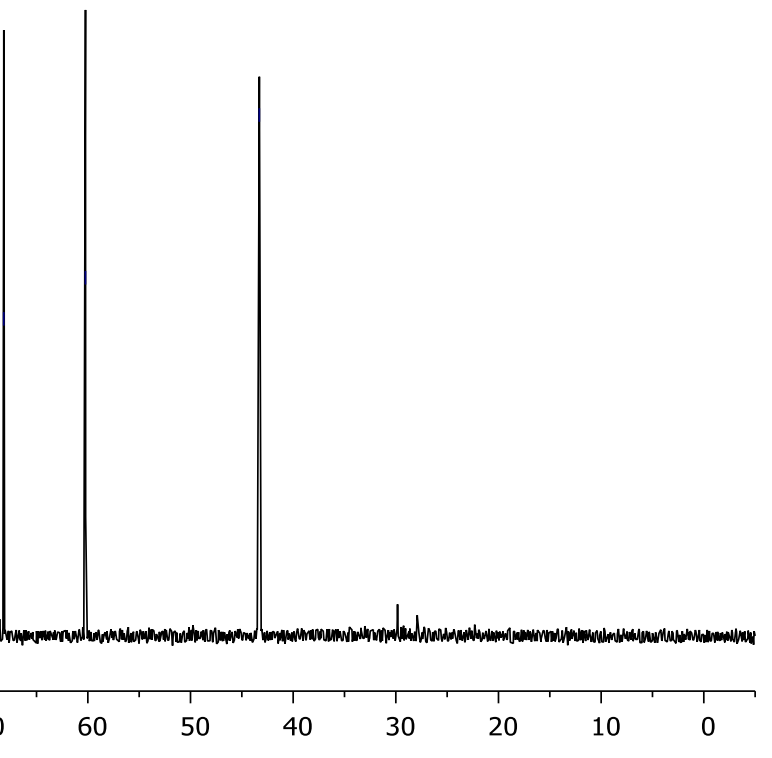




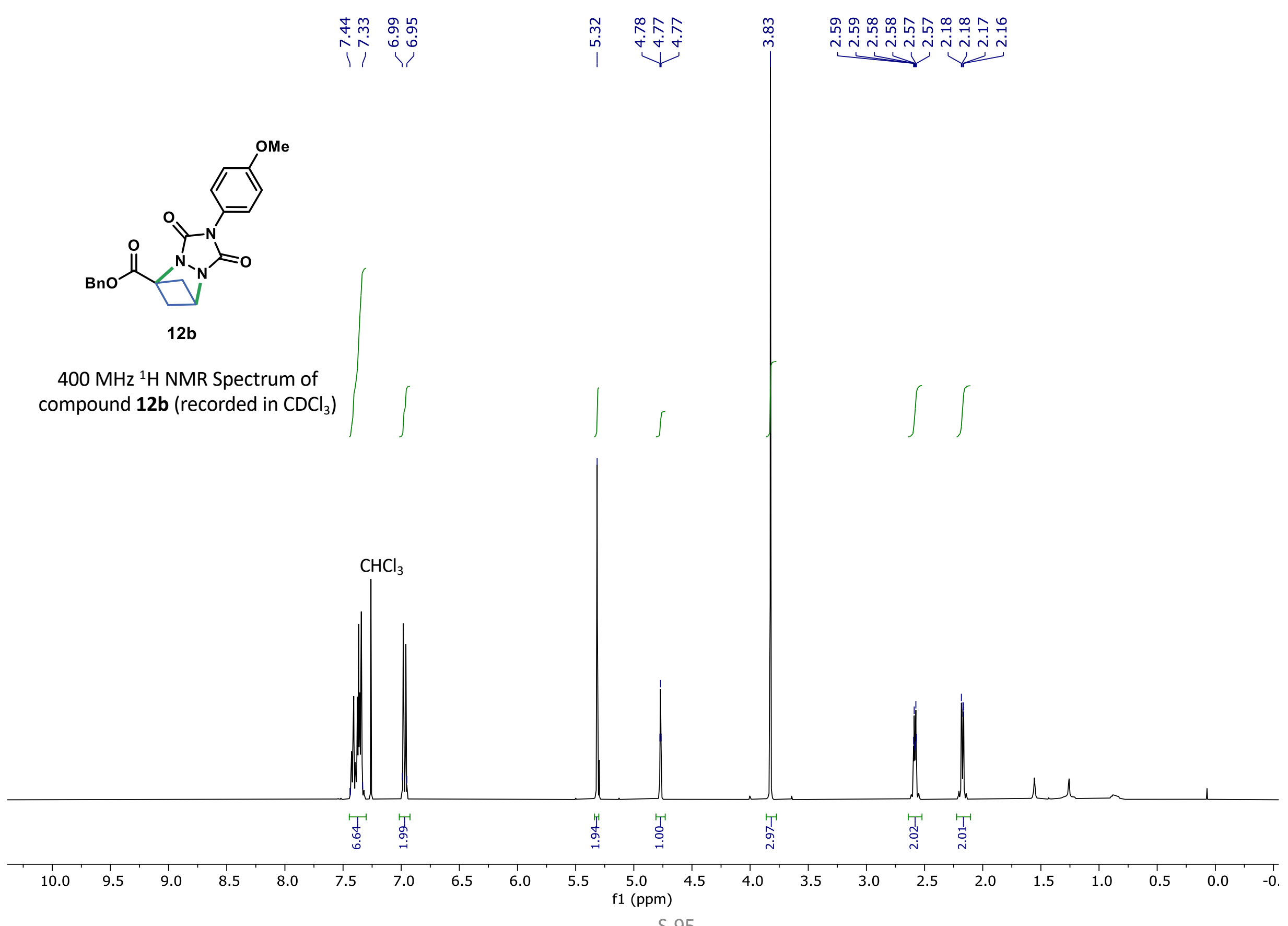




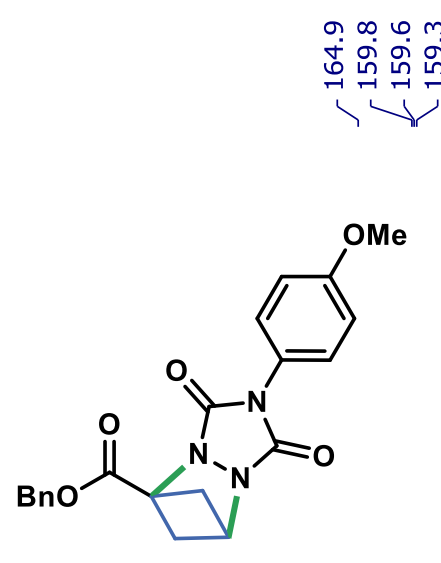

$12 b$

$101 \mathrm{MHz}{ }^{13} \mathrm{C}$ NMR Spectrum of compound $\mathbf{1 2 b}$ (recorded in $\mathrm{CDCl}_{3}$ )

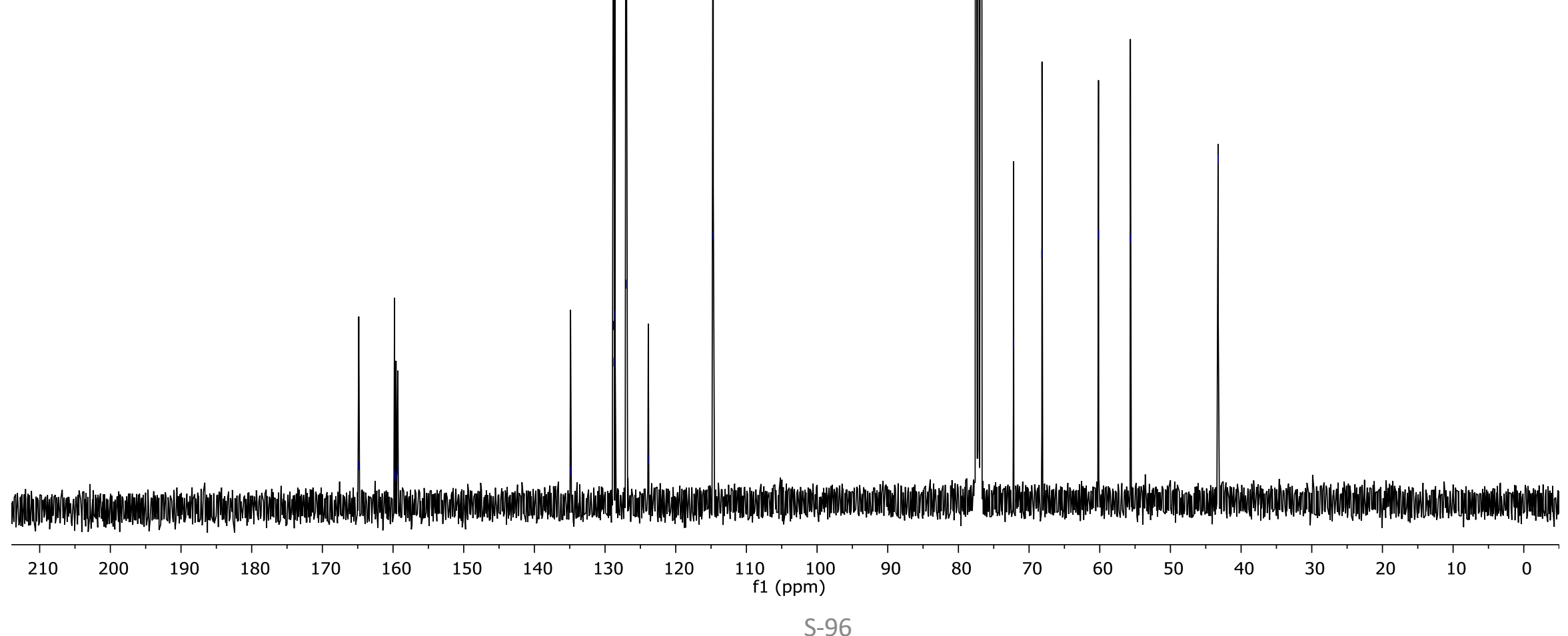




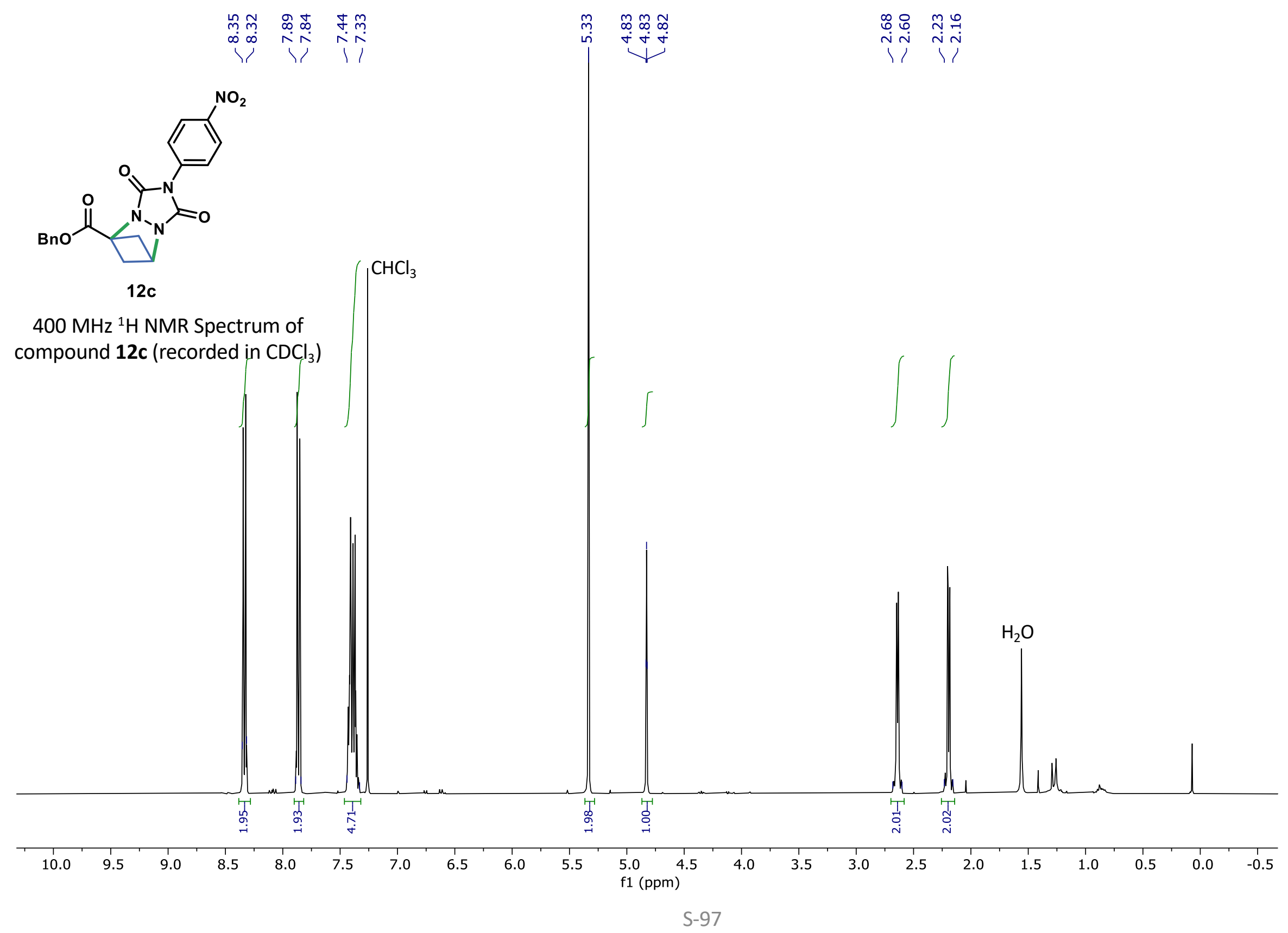




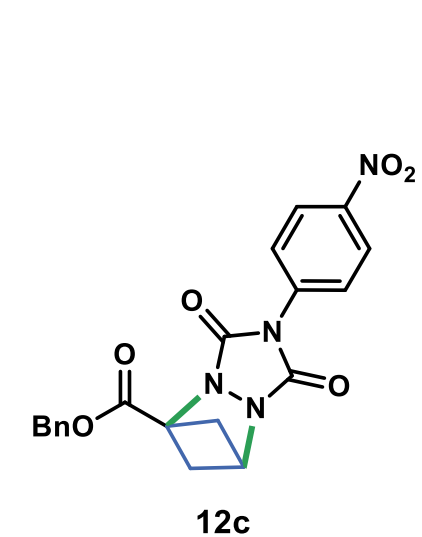

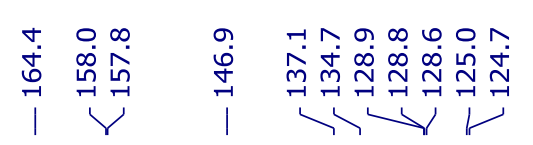

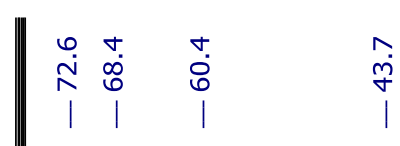

$101 \mathrm{MHz}{ }^{13} \mathrm{C}$ NMR Spectrum of compound $12 \mathrm{c}$ (recorded in $\mathrm{CDCl}_{3}$ )

$\mathrm{CDCl}_{3}$

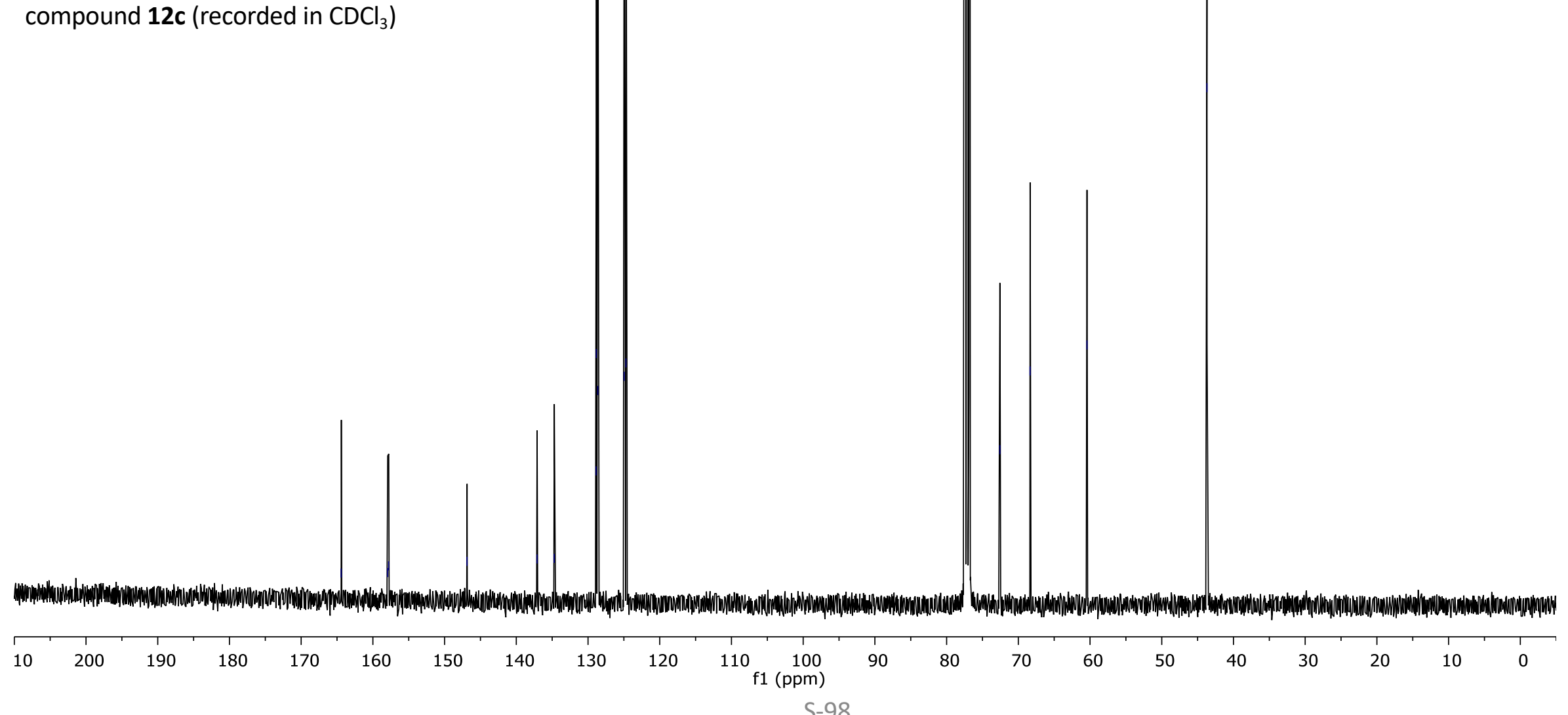




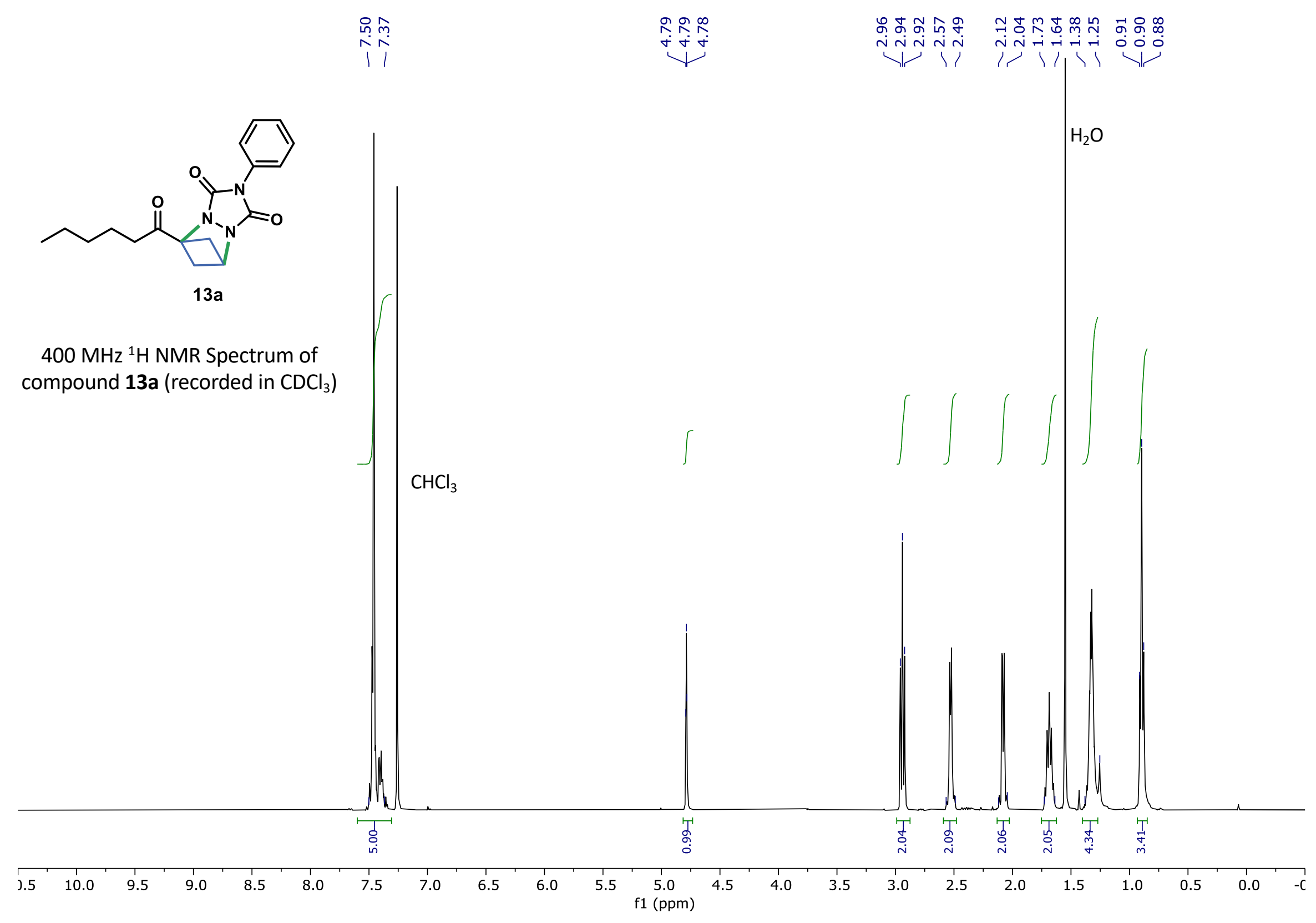

S-99 


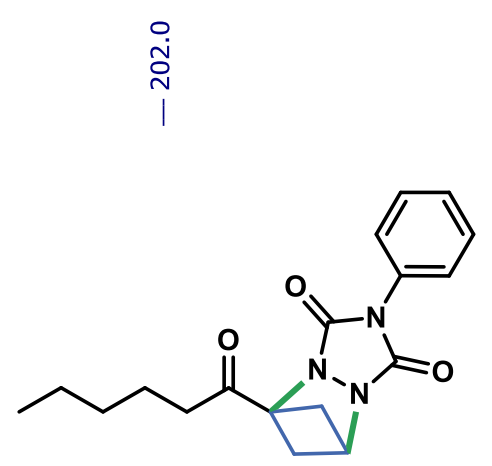

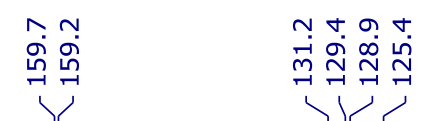

13a

$101 \mathrm{MHz}{ }^{13} \mathrm{C}$ NMR Spectrum of compound 13a (recorded in $\mathrm{CDCl}_{3}$ )

$\mathrm{CDCl}_{3}$

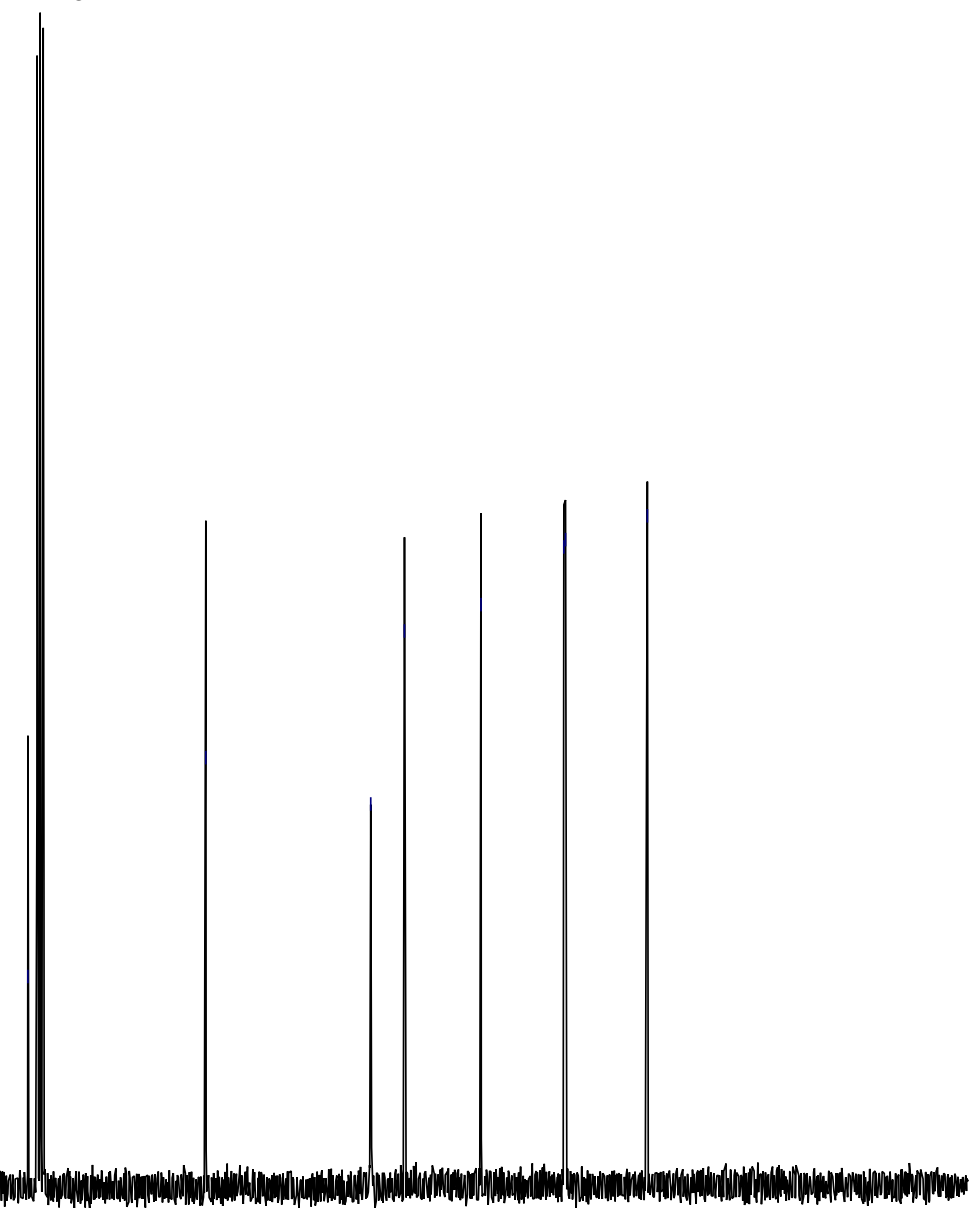

70

60

50 


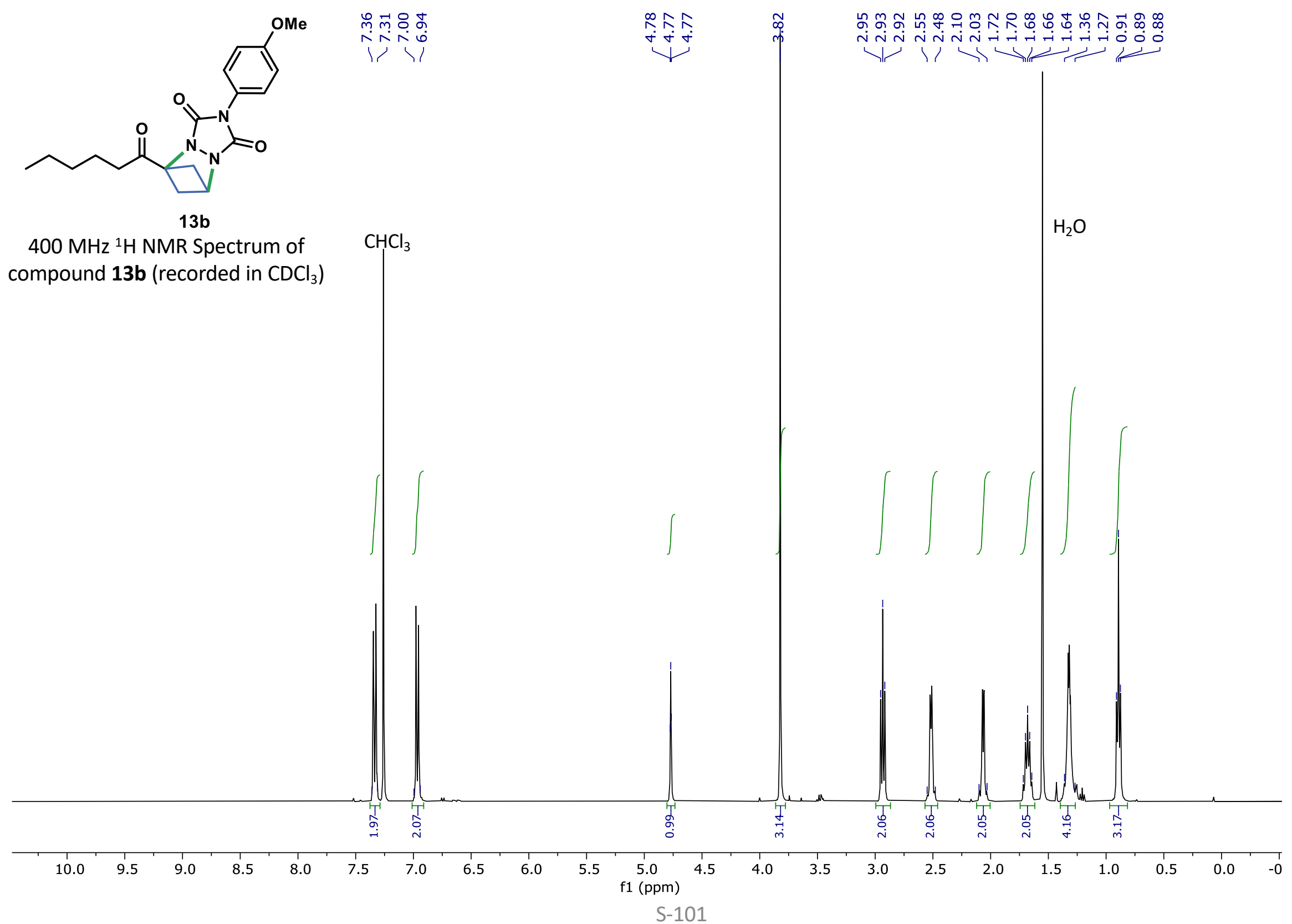




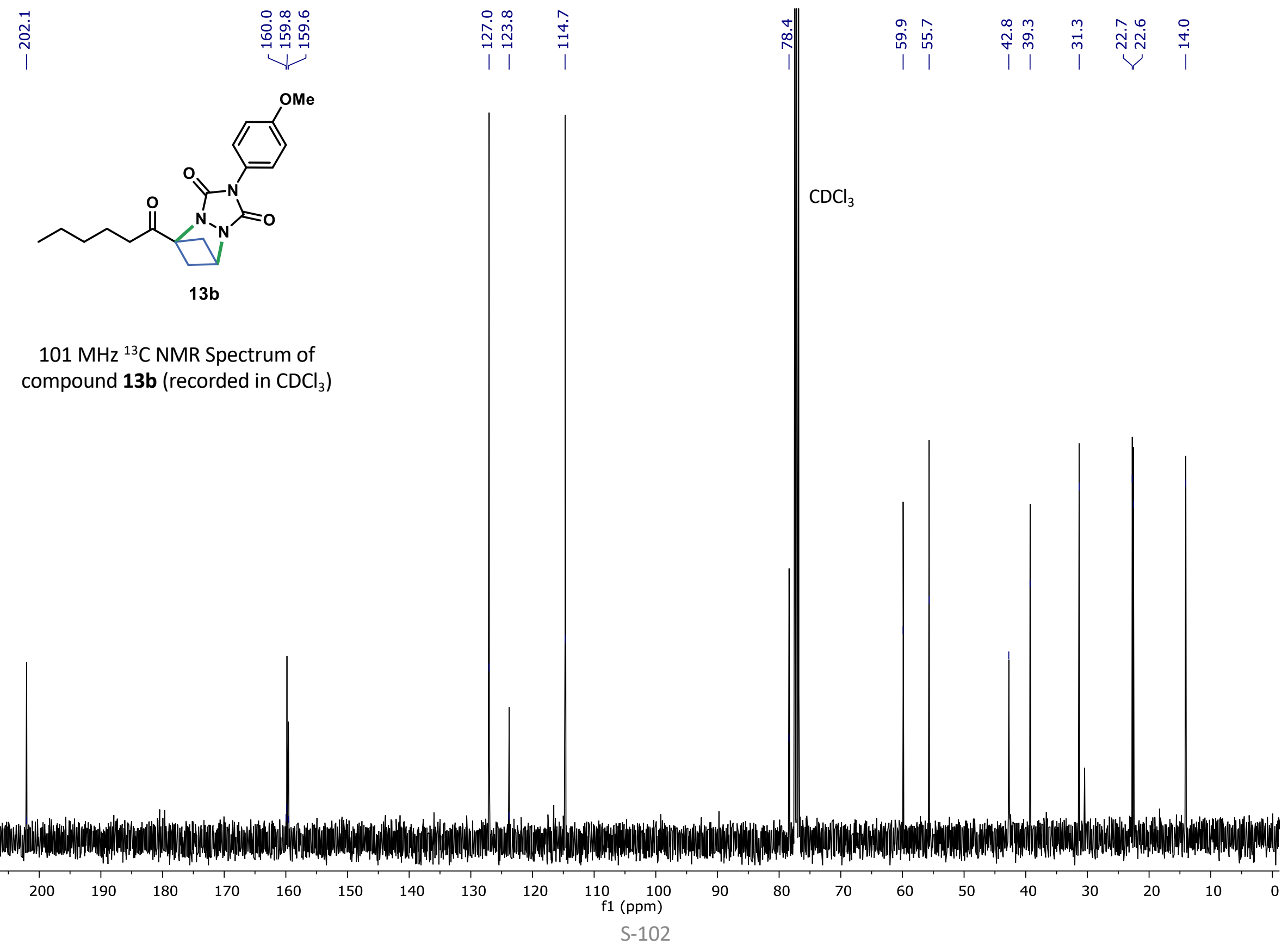




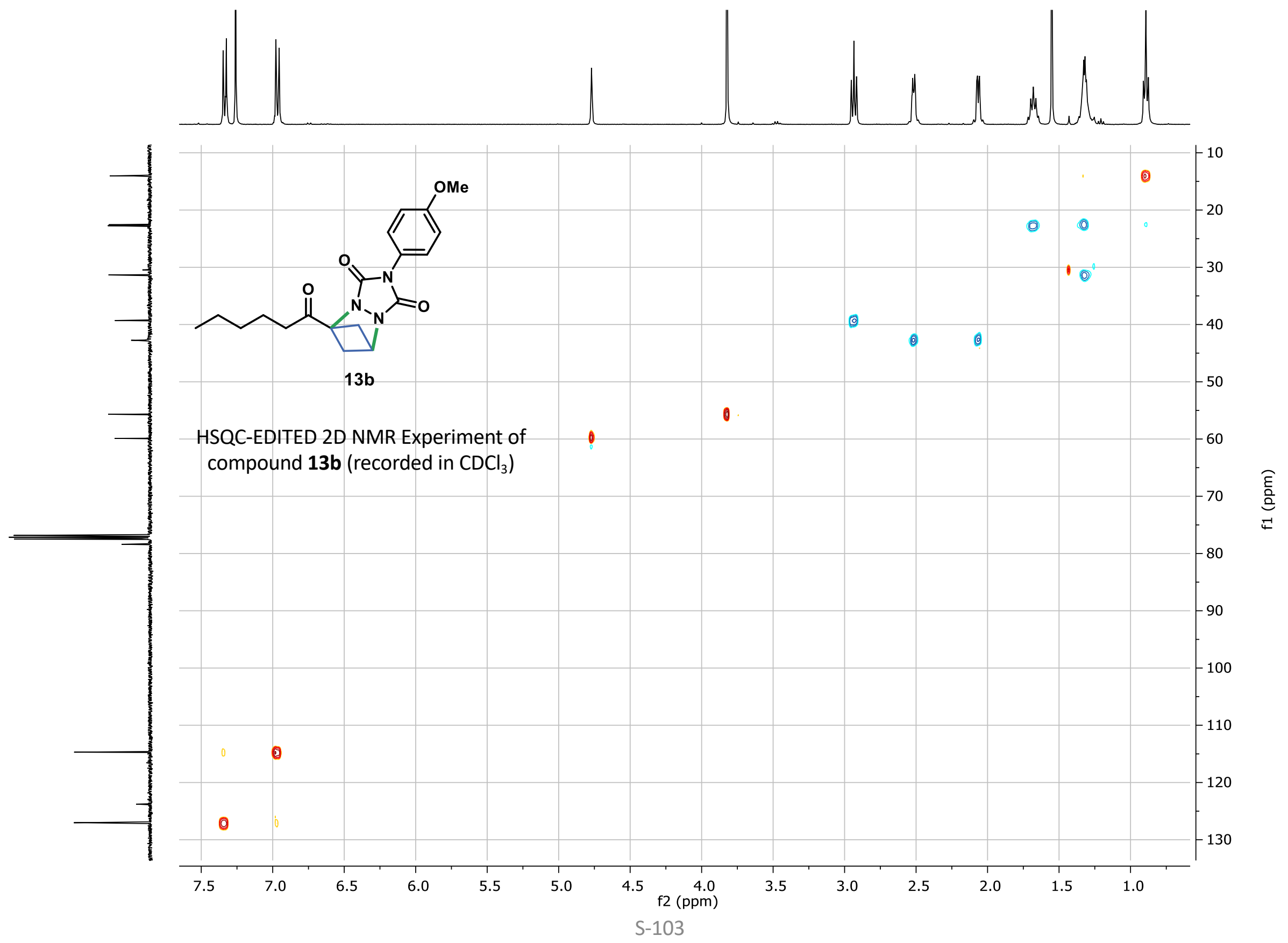




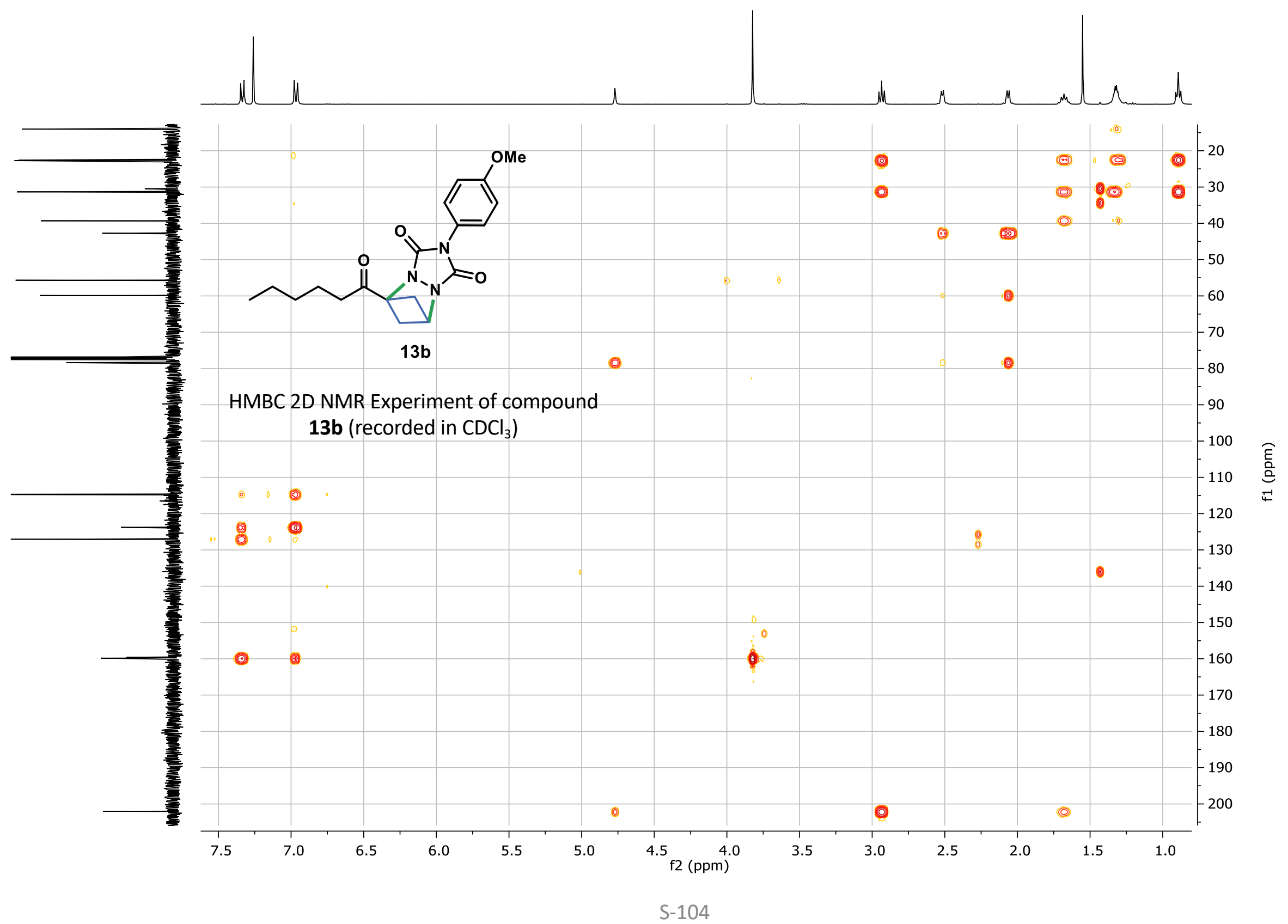




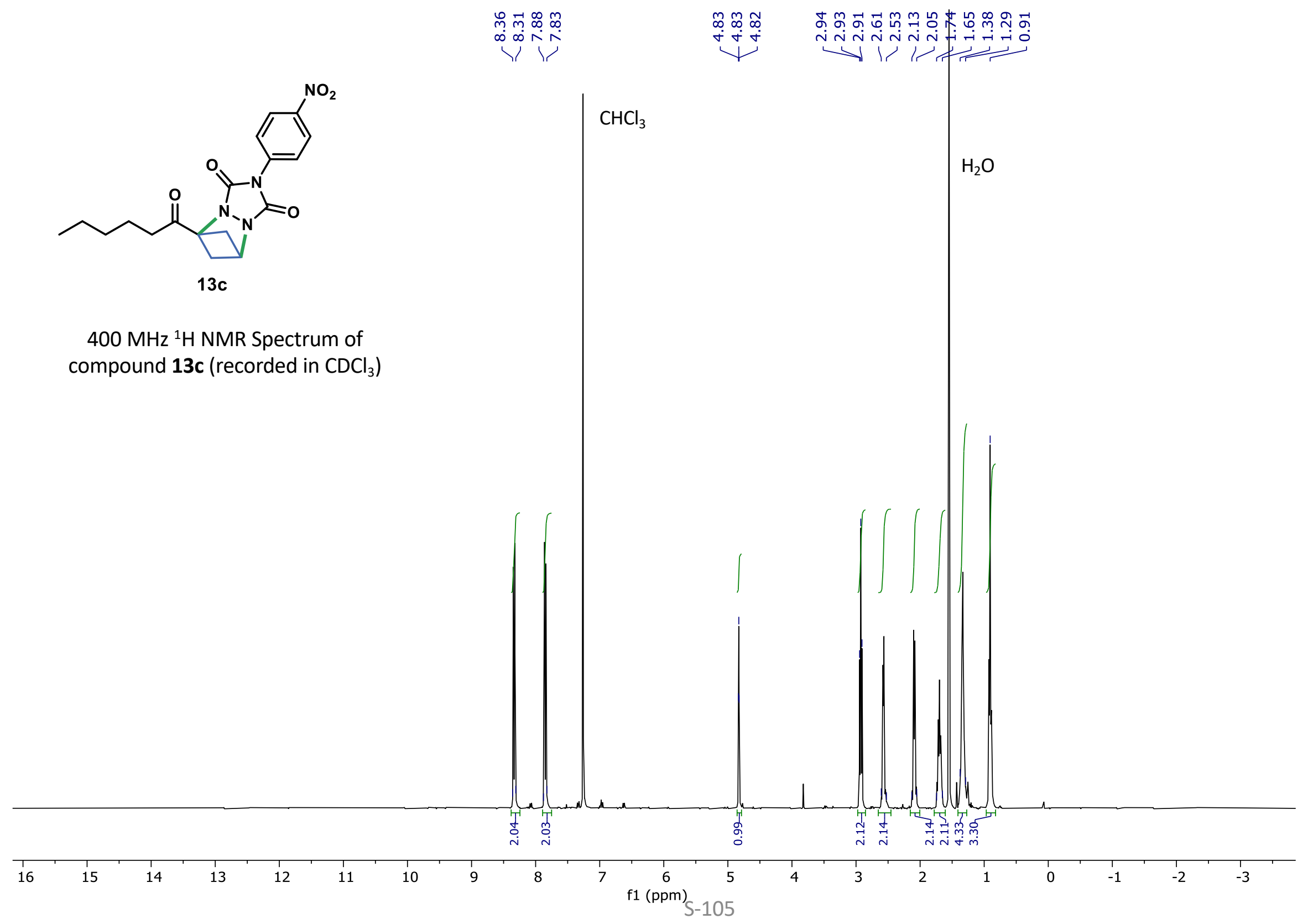




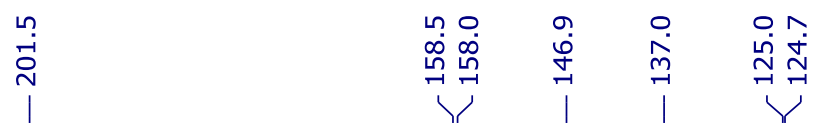

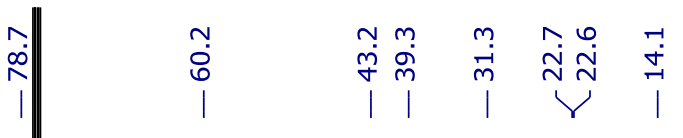

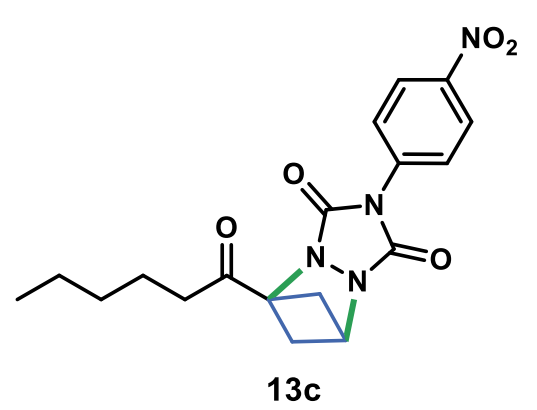

$101 \mathrm{MHz}{ }^{13} \mathrm{C}$ NMR Spectrum of compound $13 \mathrm{c}$ (recorded in $\mathrm{CDCl}_{3}$ )

$\mathrm{CDCl}_{3}$

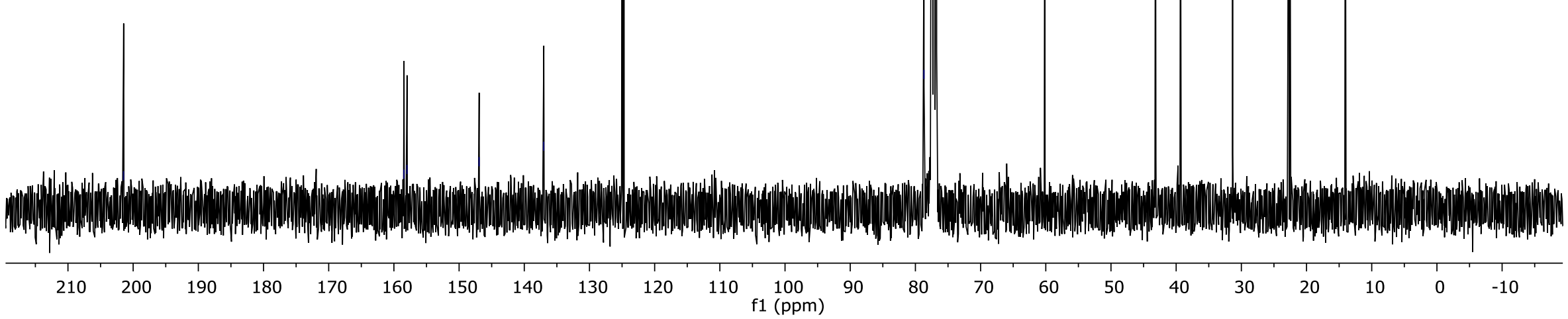




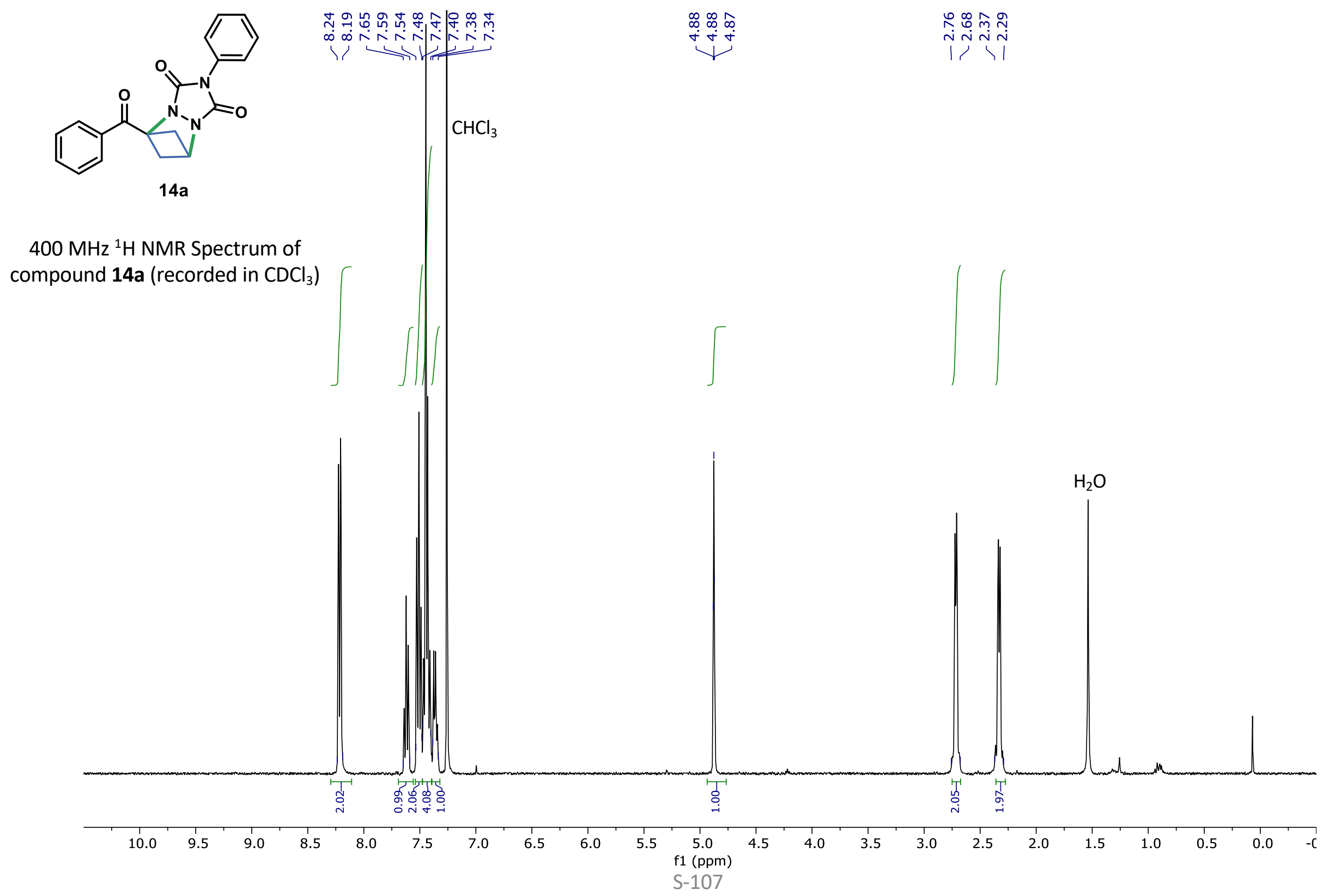




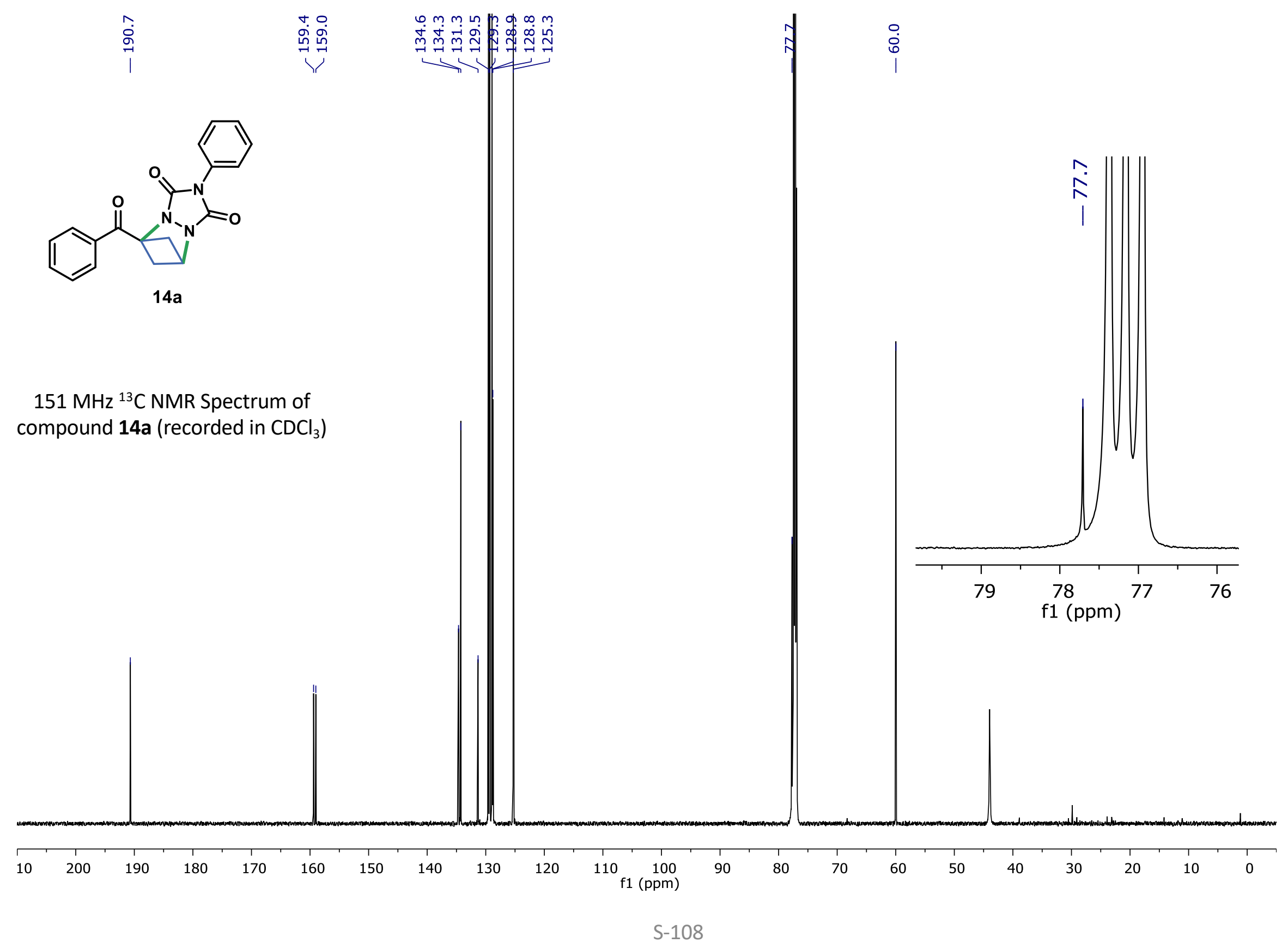




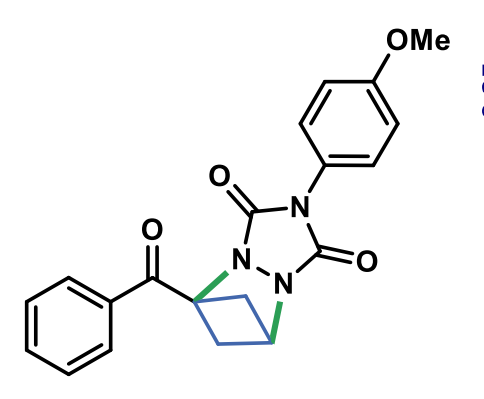

$14 b$

$400 \mathrm{MHz}{ }^{1} \mathrm{H}$ NMR Spectrum of compound $\mathbf{1 4 b}$ (recorded in $\mathrm{CDCl}_{3}$ )

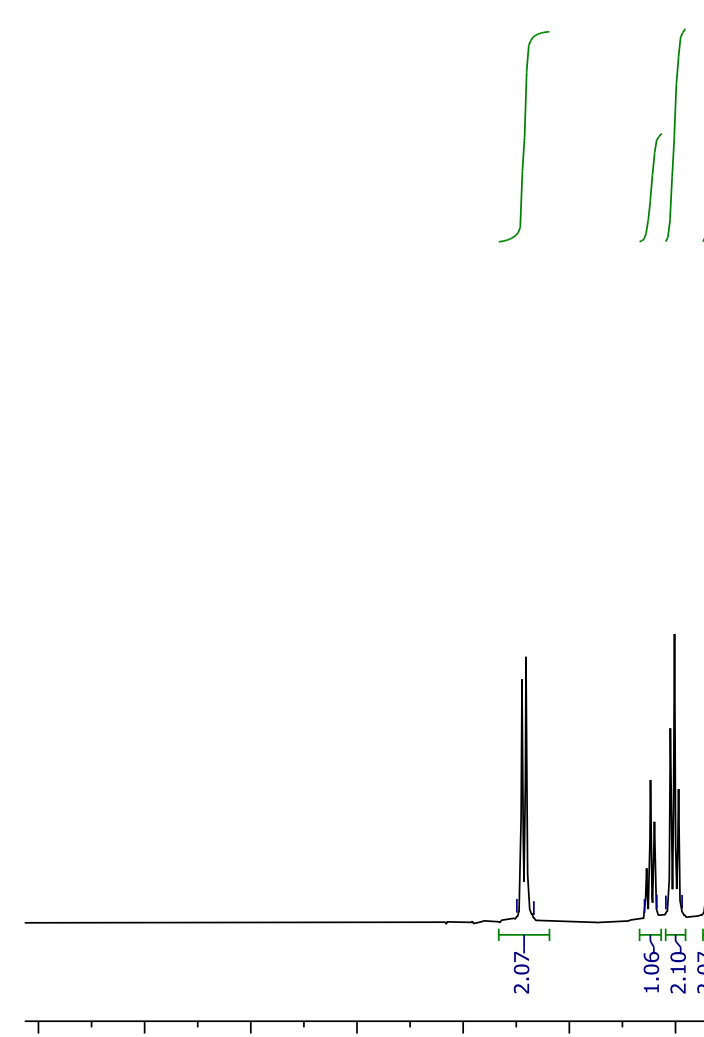

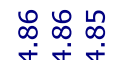

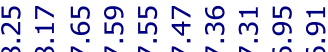

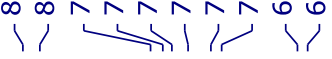

$0.5 \quad 10.0$ 9.5 9.0 8.5 $5 \quad 7.0$ 6.5
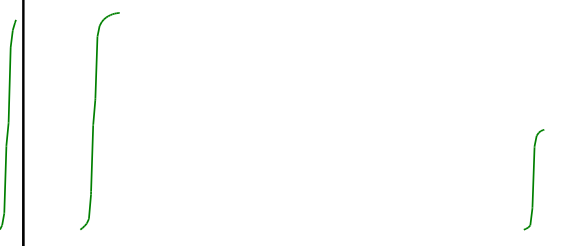

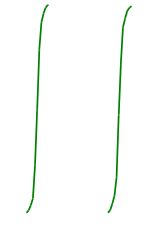



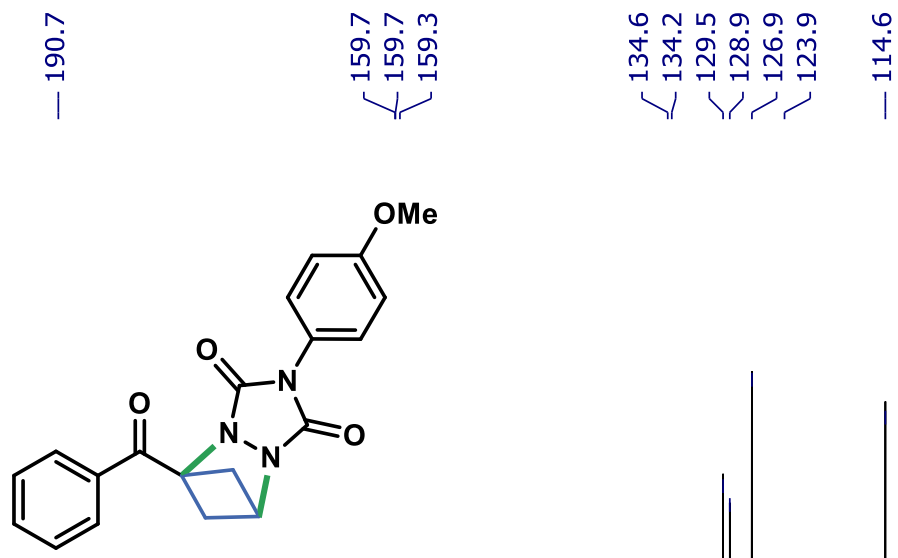

$14 b$

$101 \mathrm{MHz}{ }^{13} \mathrm{C}$ NMR Spectrum of compound 14b (recorded in $\mathrm{CDCl}_{3}$ )

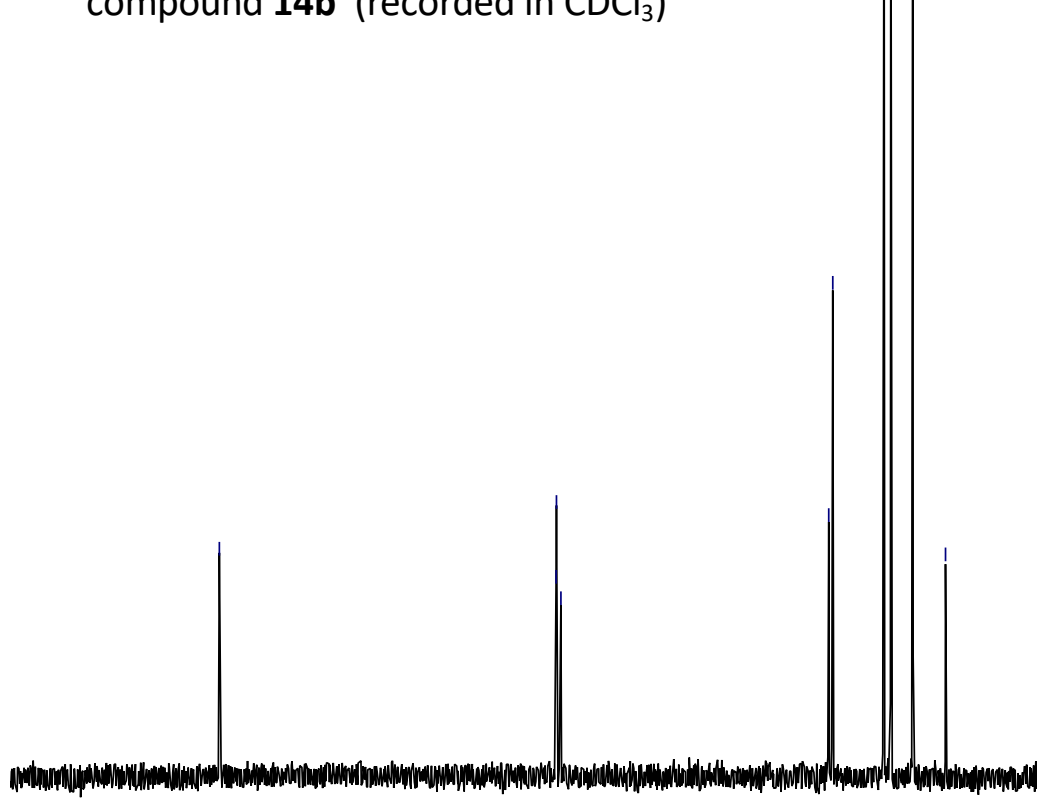

ฟ||

$\mathrm{CDCl}_{3}$
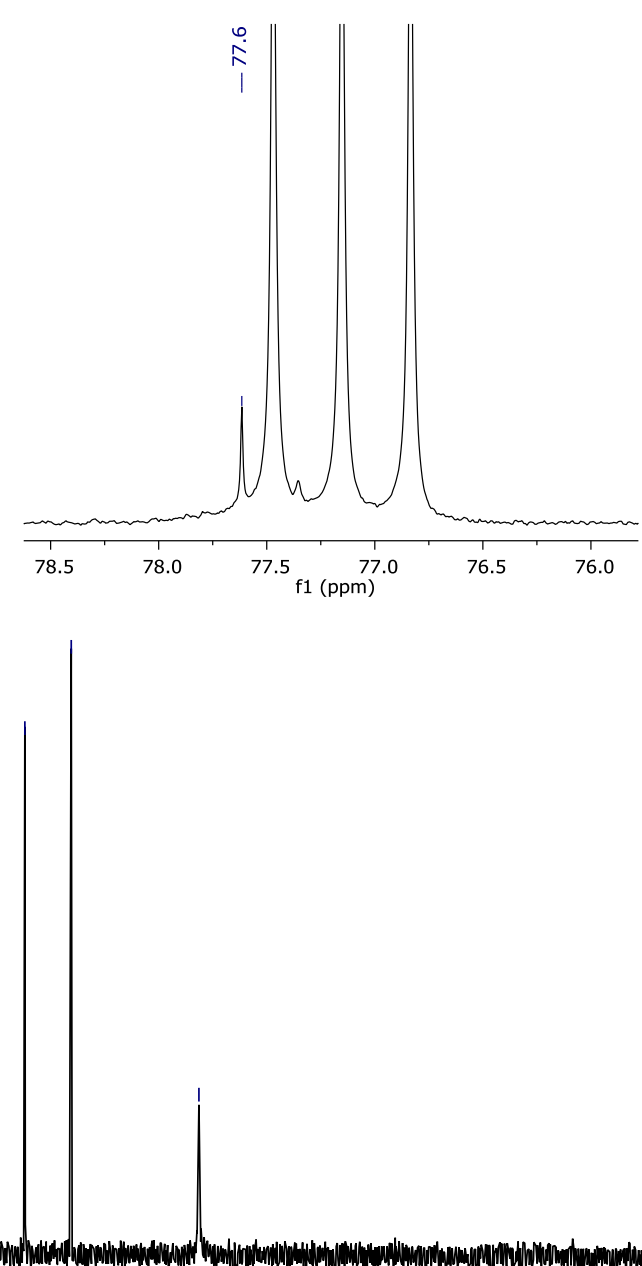

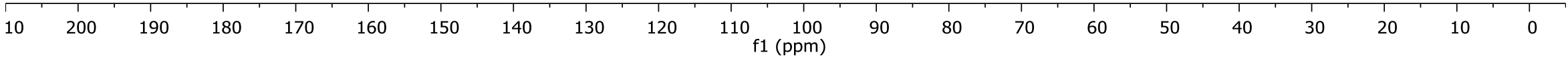




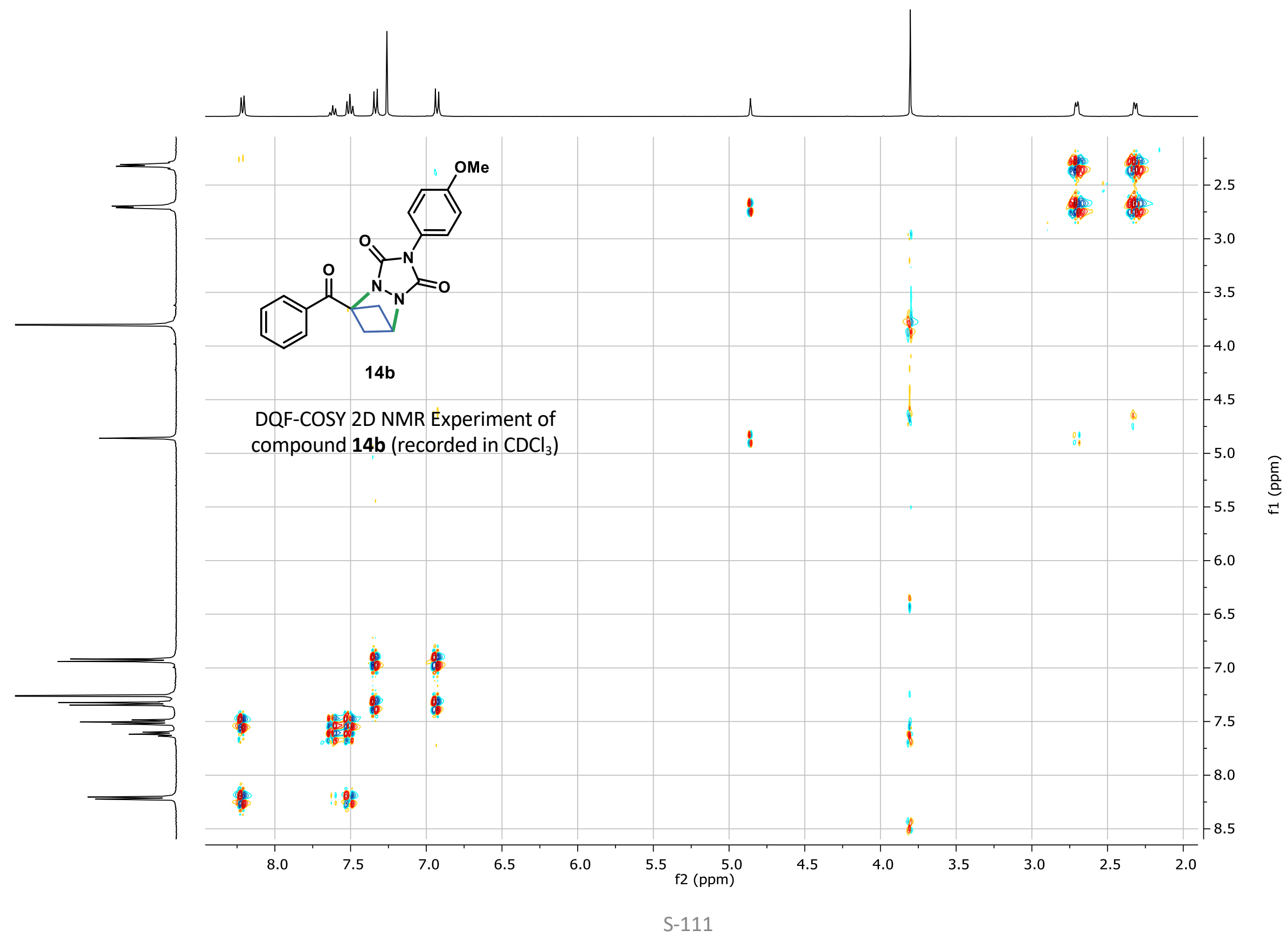




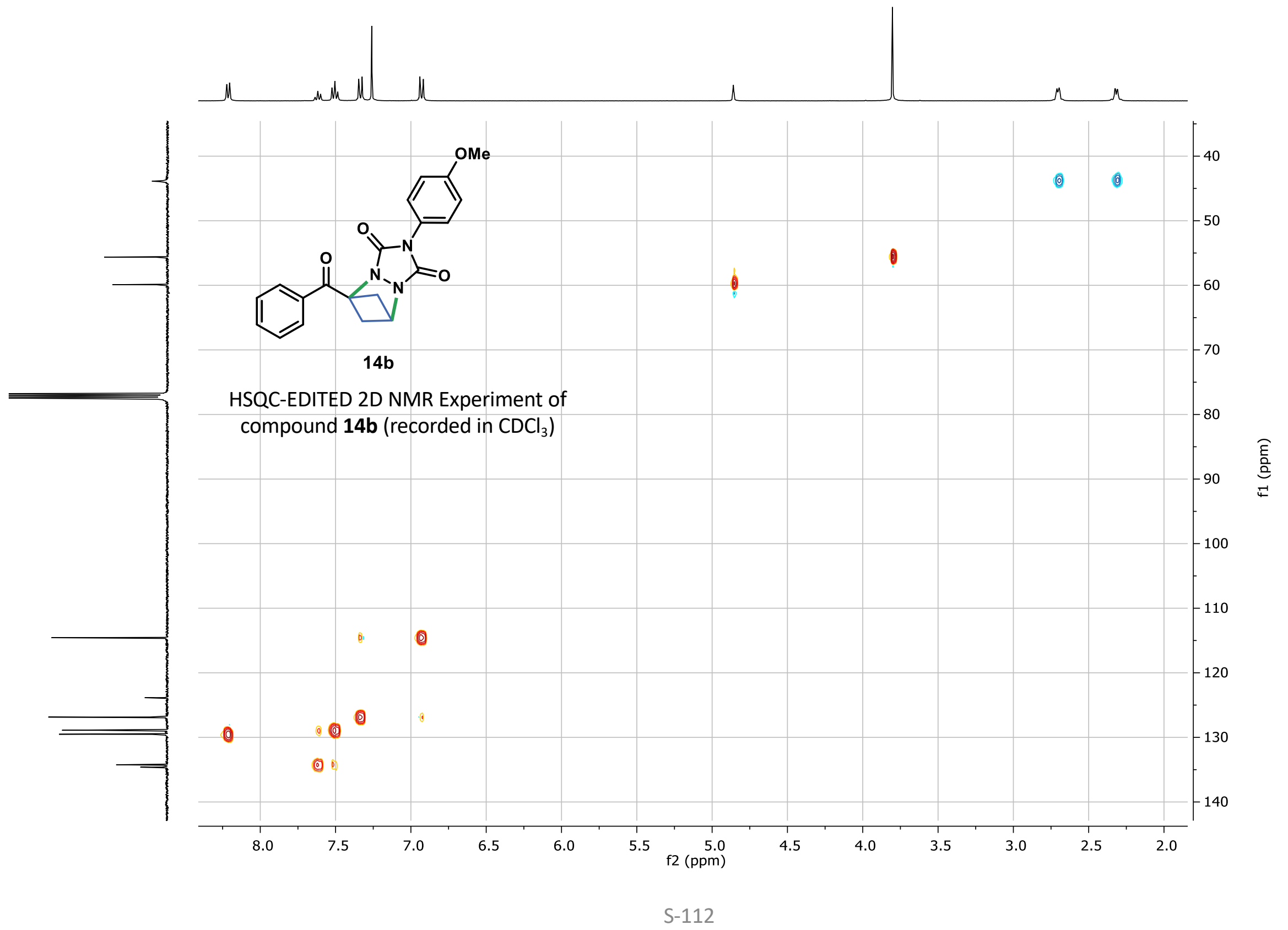




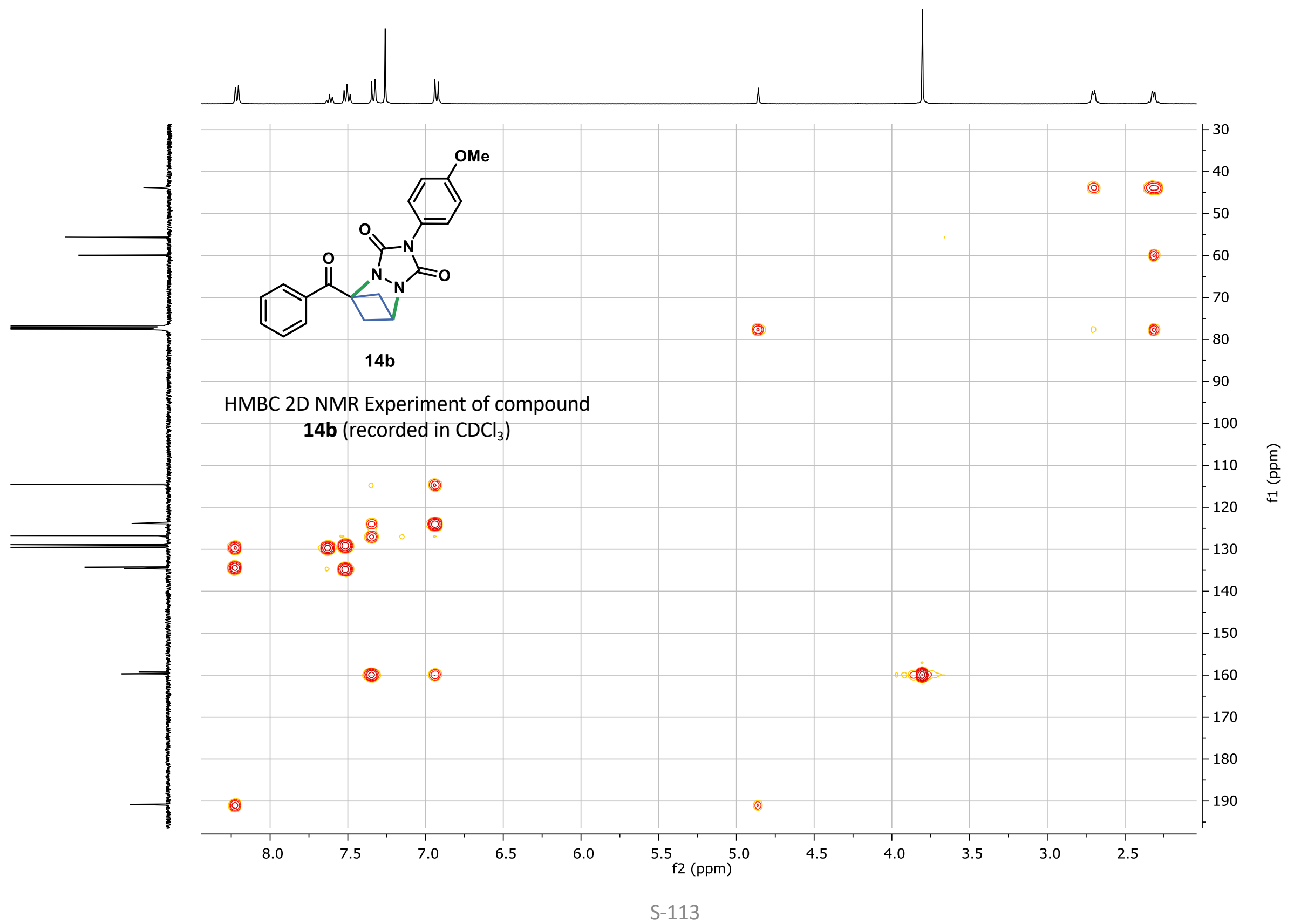




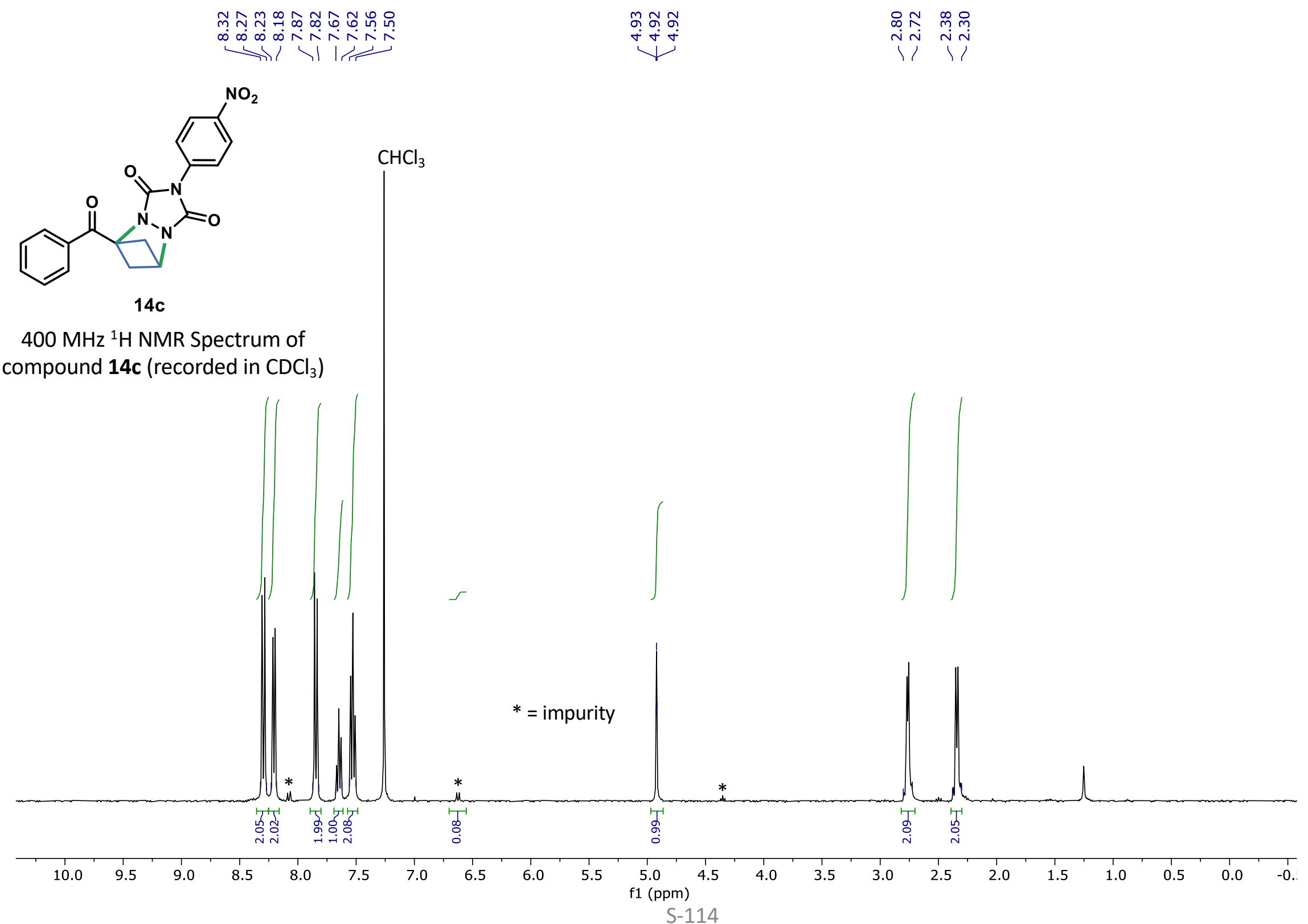




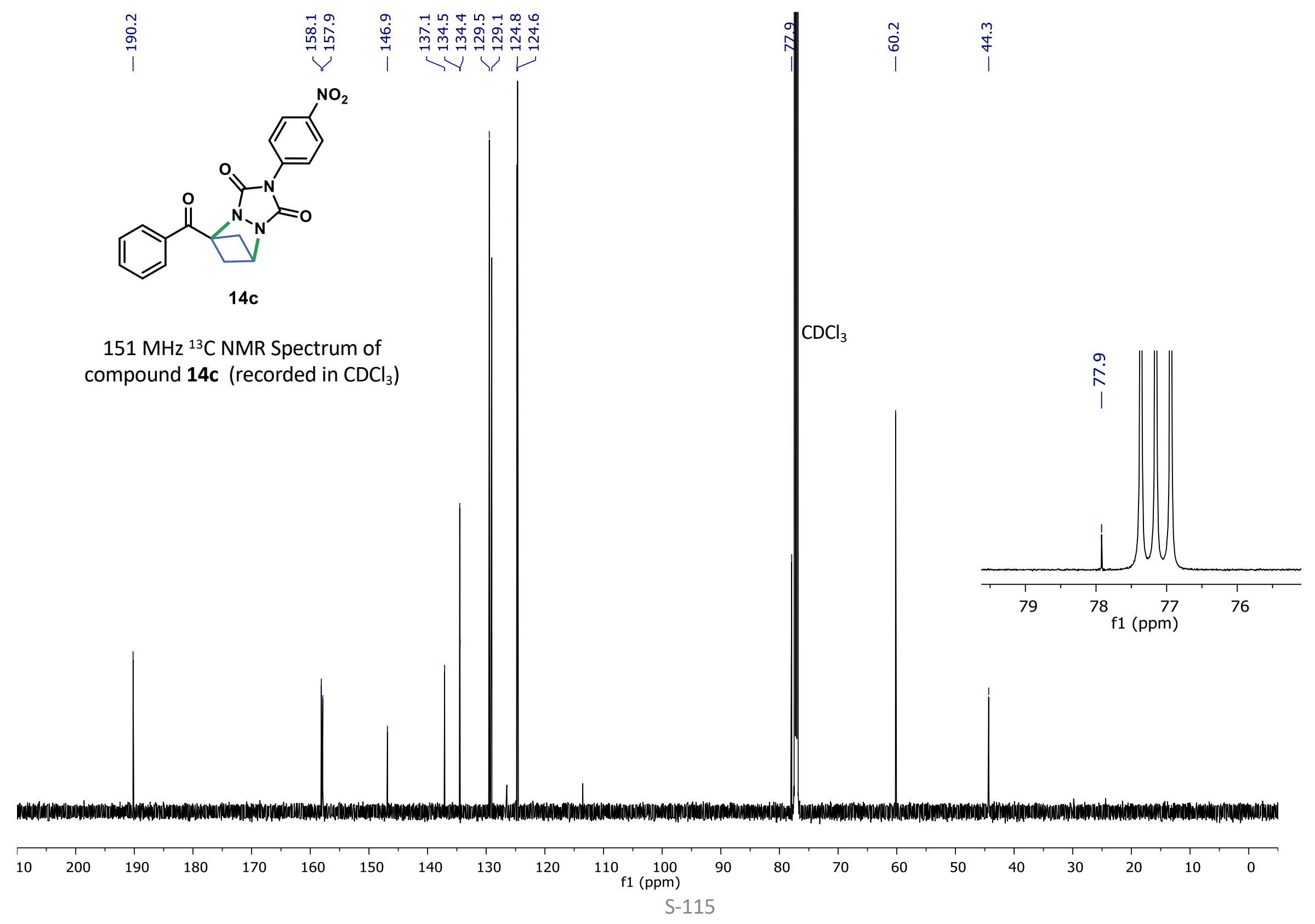




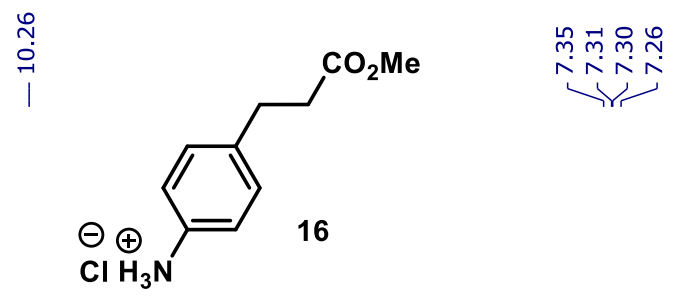

$400 \mathrm{MHz}{ }^{1} \mathrm{H}$ NMR Spectrum of compound 16 (recorded in DMSO- $d_{6}$ )

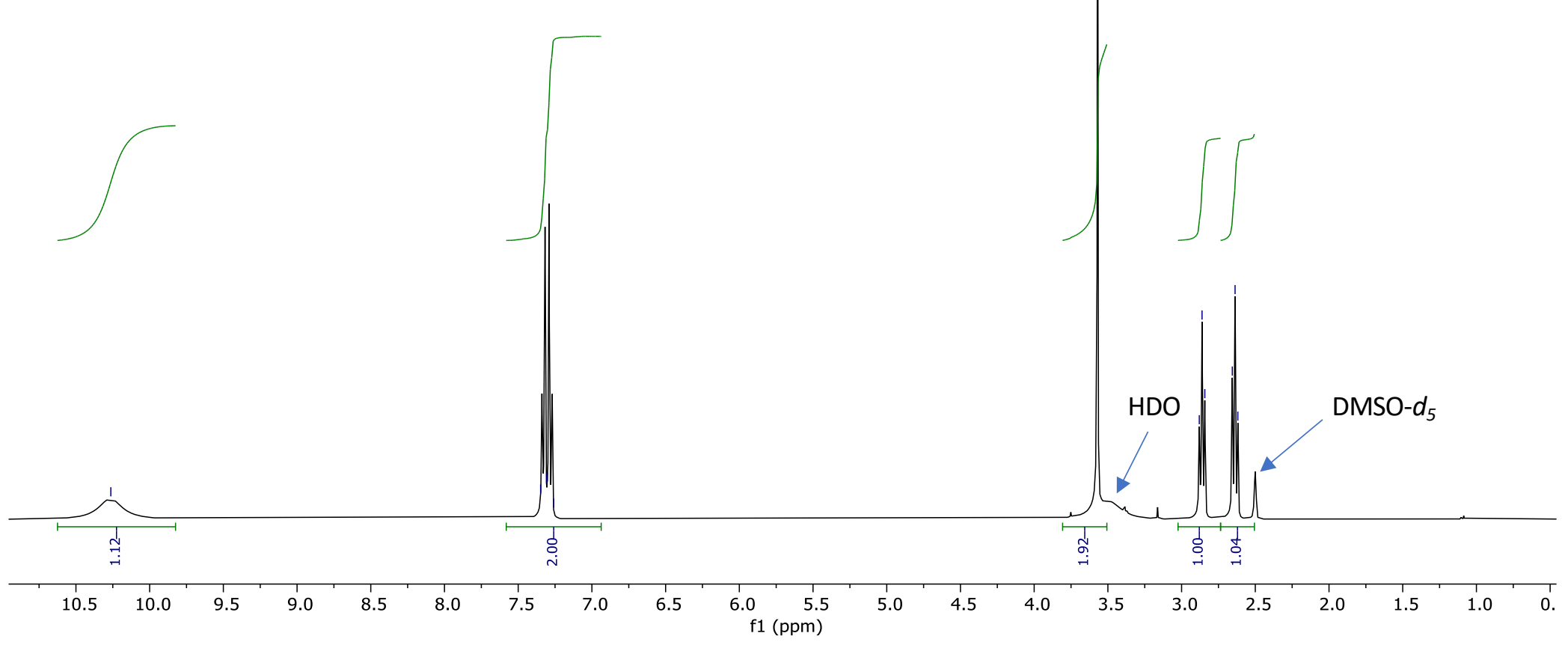




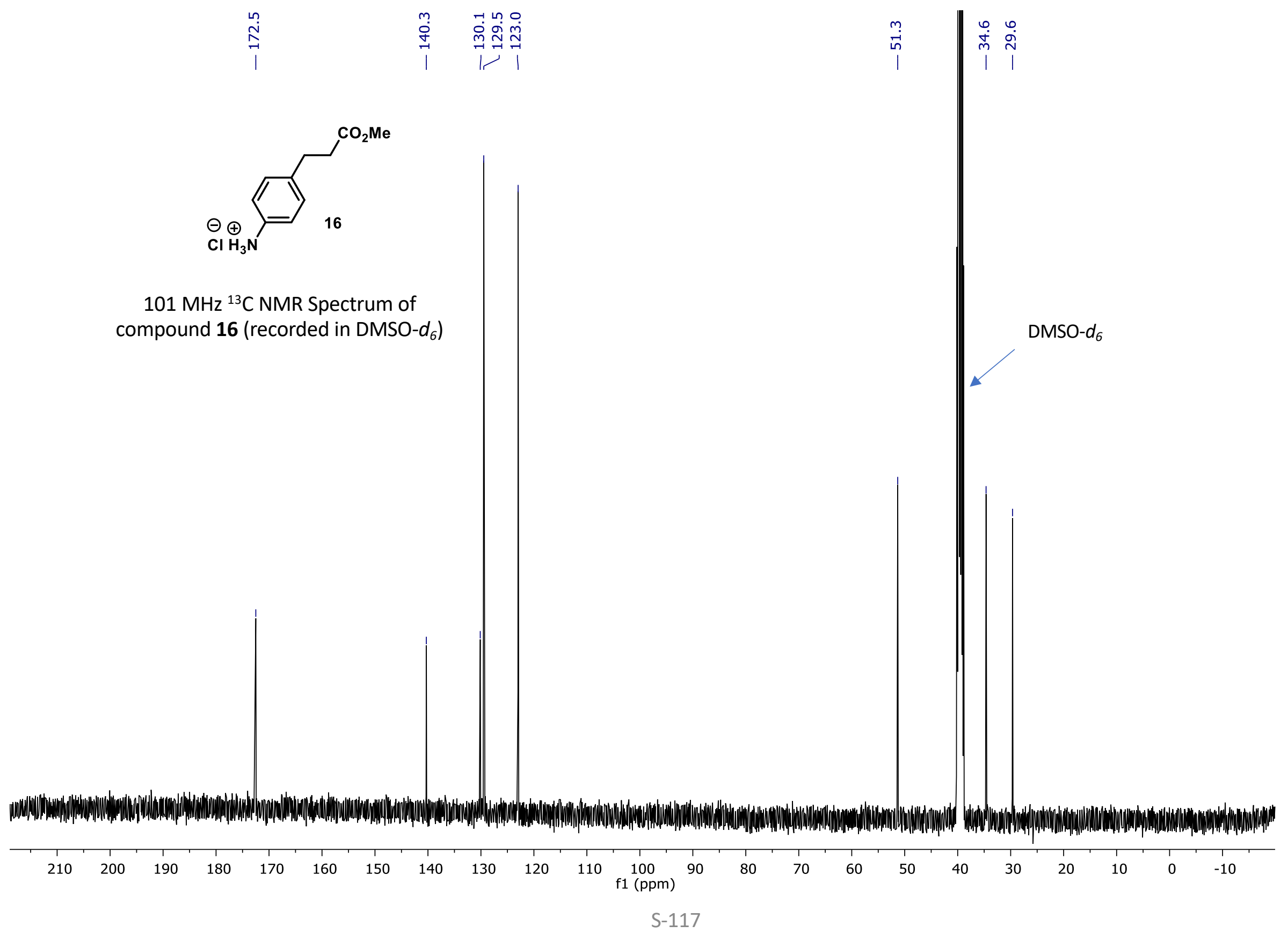




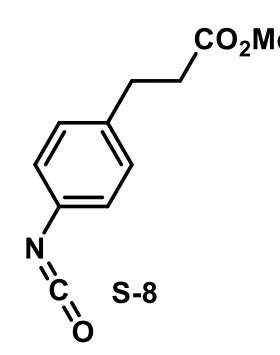

굿굿 웅

रा।

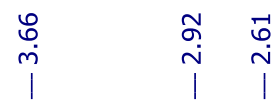

$400 \mathrm{MHz}{ }^{1} \mathrm{H}$ NMR Spectrum of compound S-8 (recorded in $\mathrm{CDCl}_{3}$ ) 


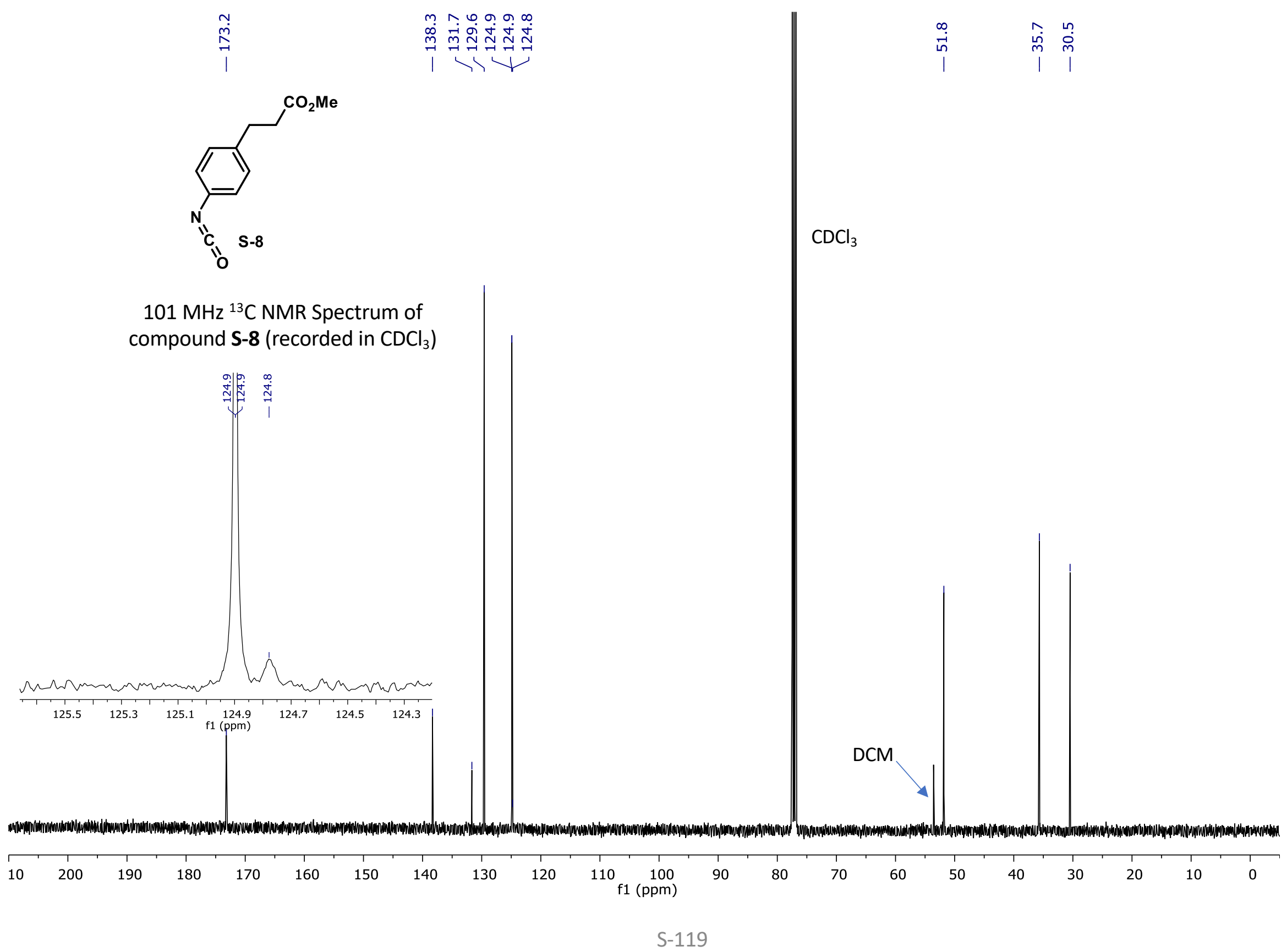




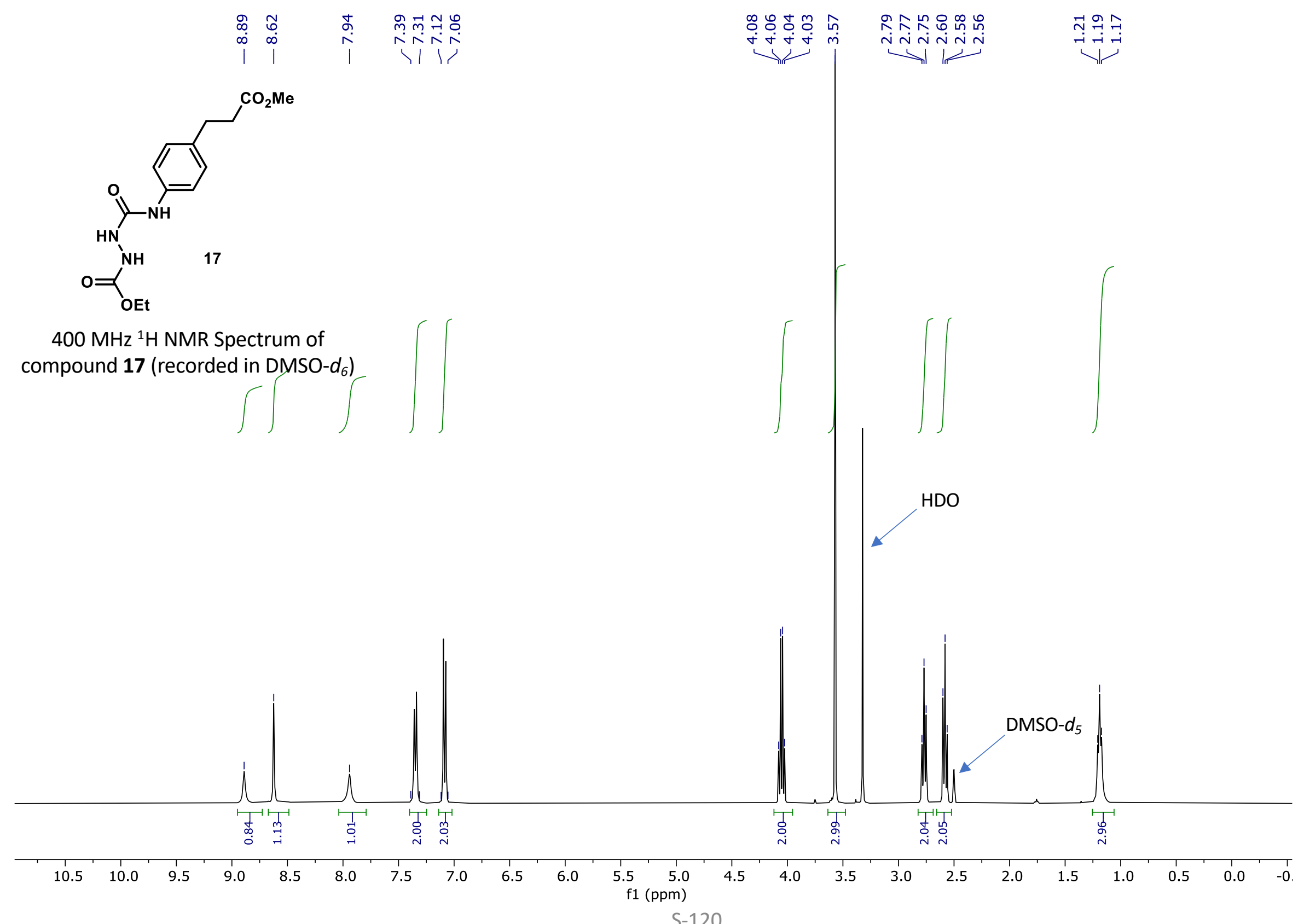




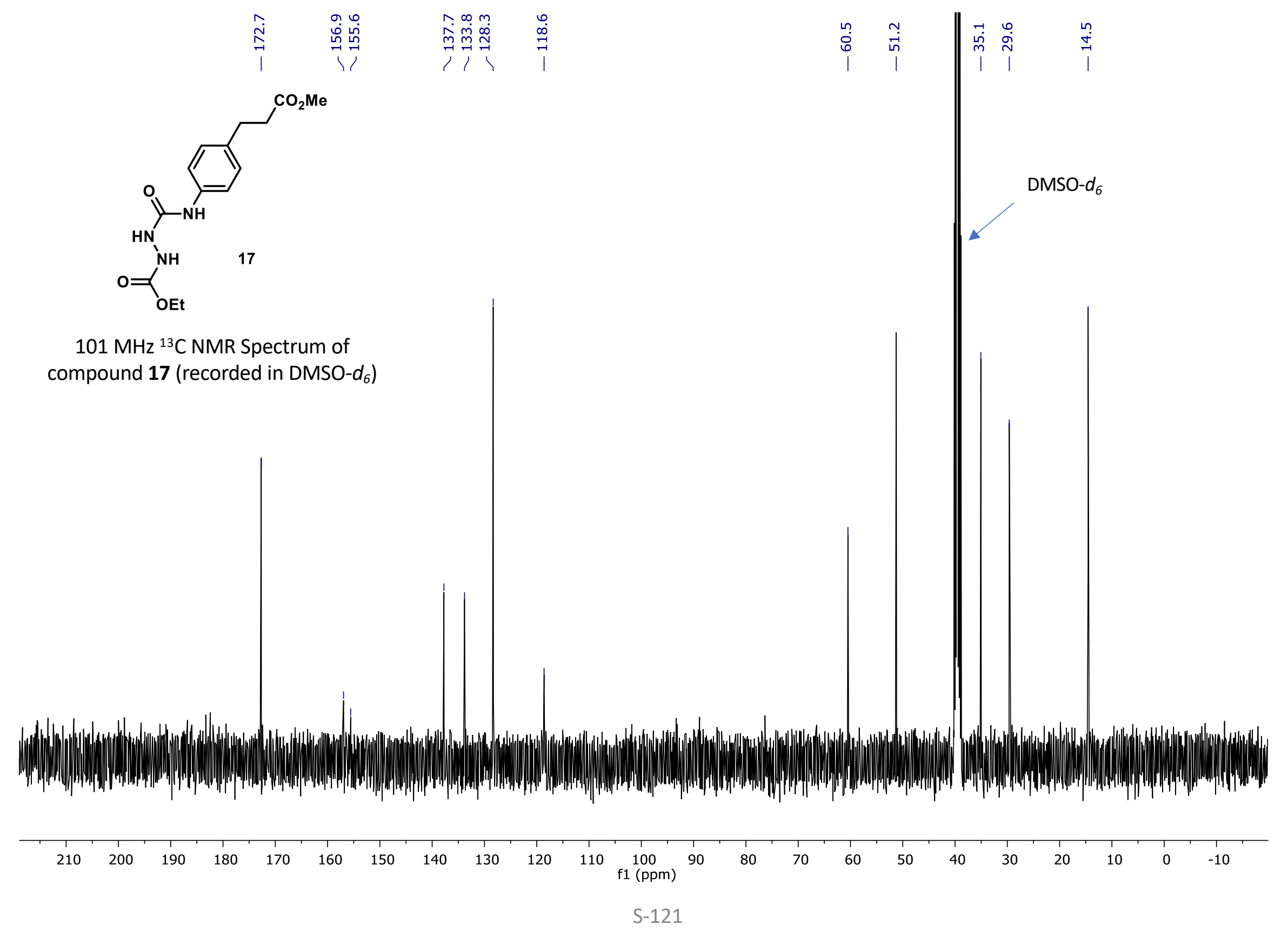




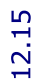

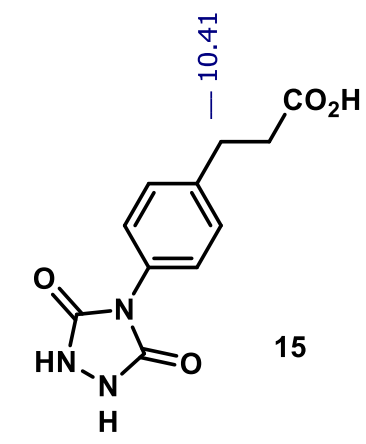

$400 \mathrm{MHz}{ }^{1} \mathrm{H}$ NMR Spectrum of compound 15 (recorded in DMSO- $d_{6}$ )

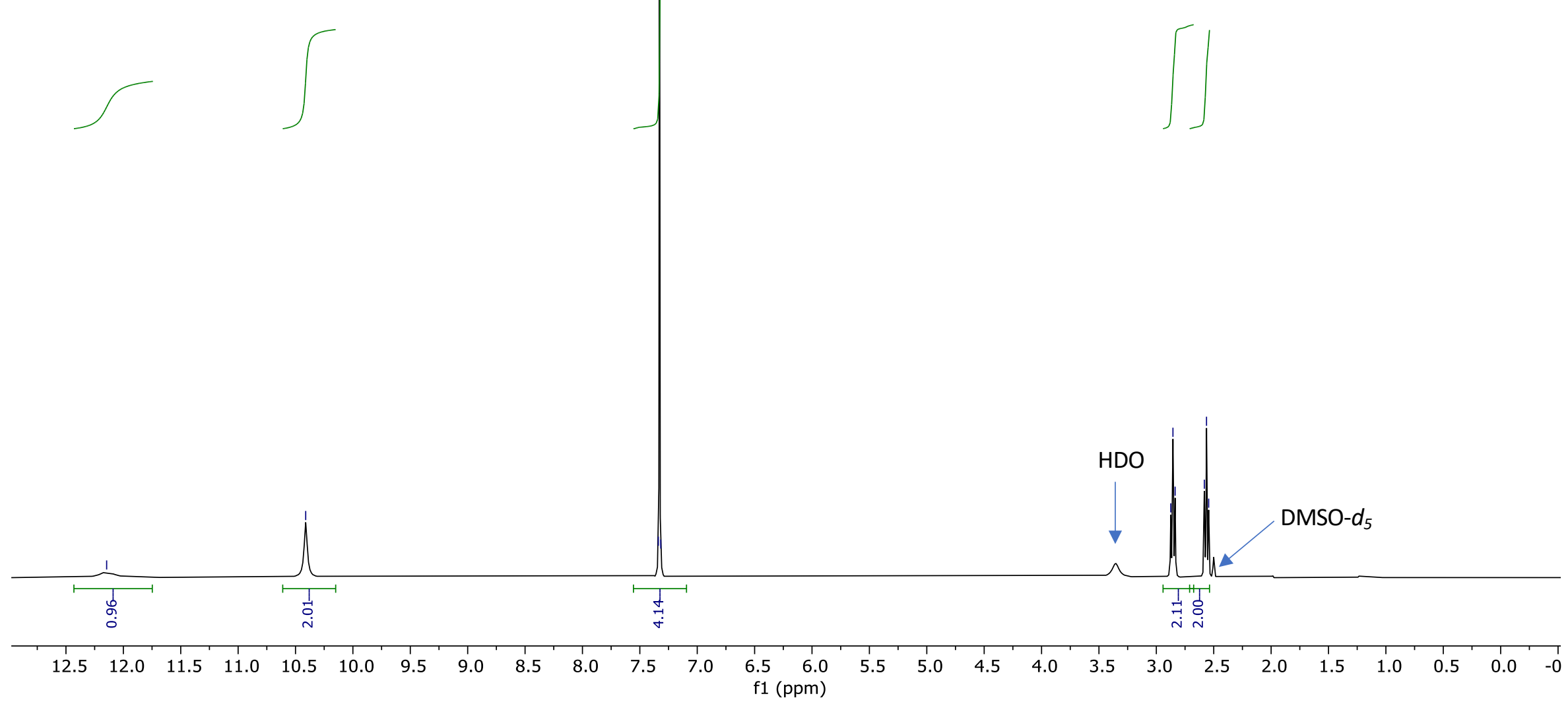

ô

ن

$\stackrel{m}{m}$

$\rightarrow$

. 


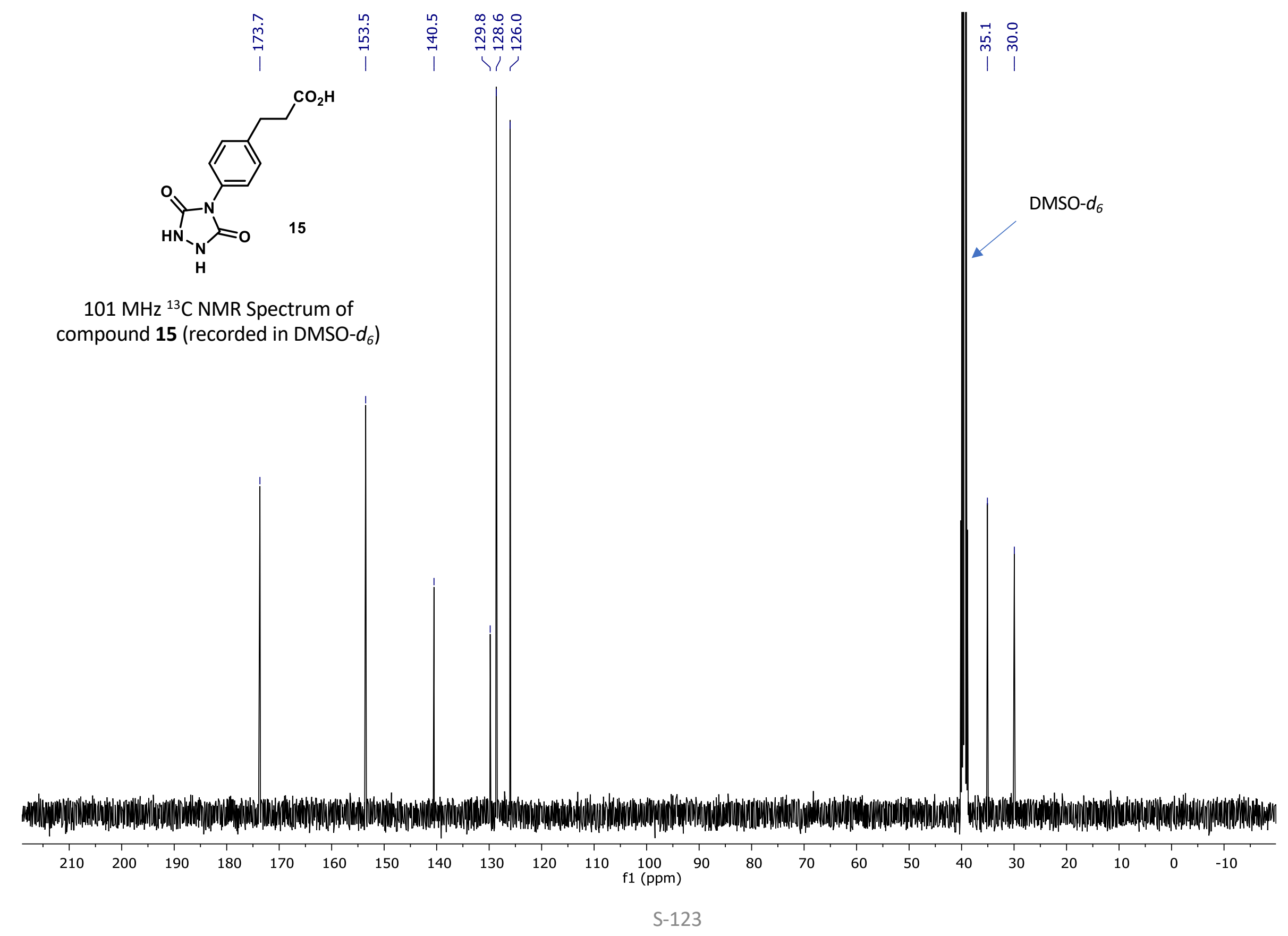




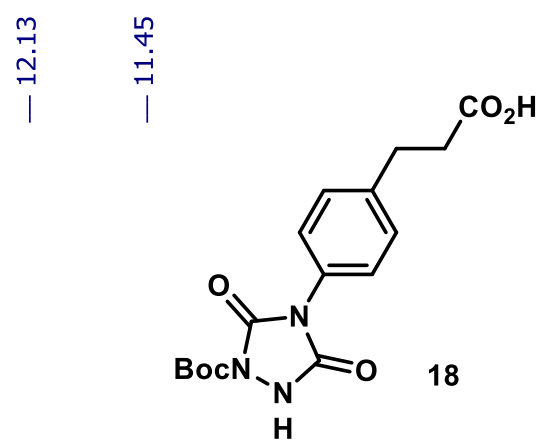

$400 \mathrm{MHz}^{1} \mathrm{H}$ NMR Spectrum of compound 18 derived from BOC-ON (recorded in DMSO- $d_{6}$ )

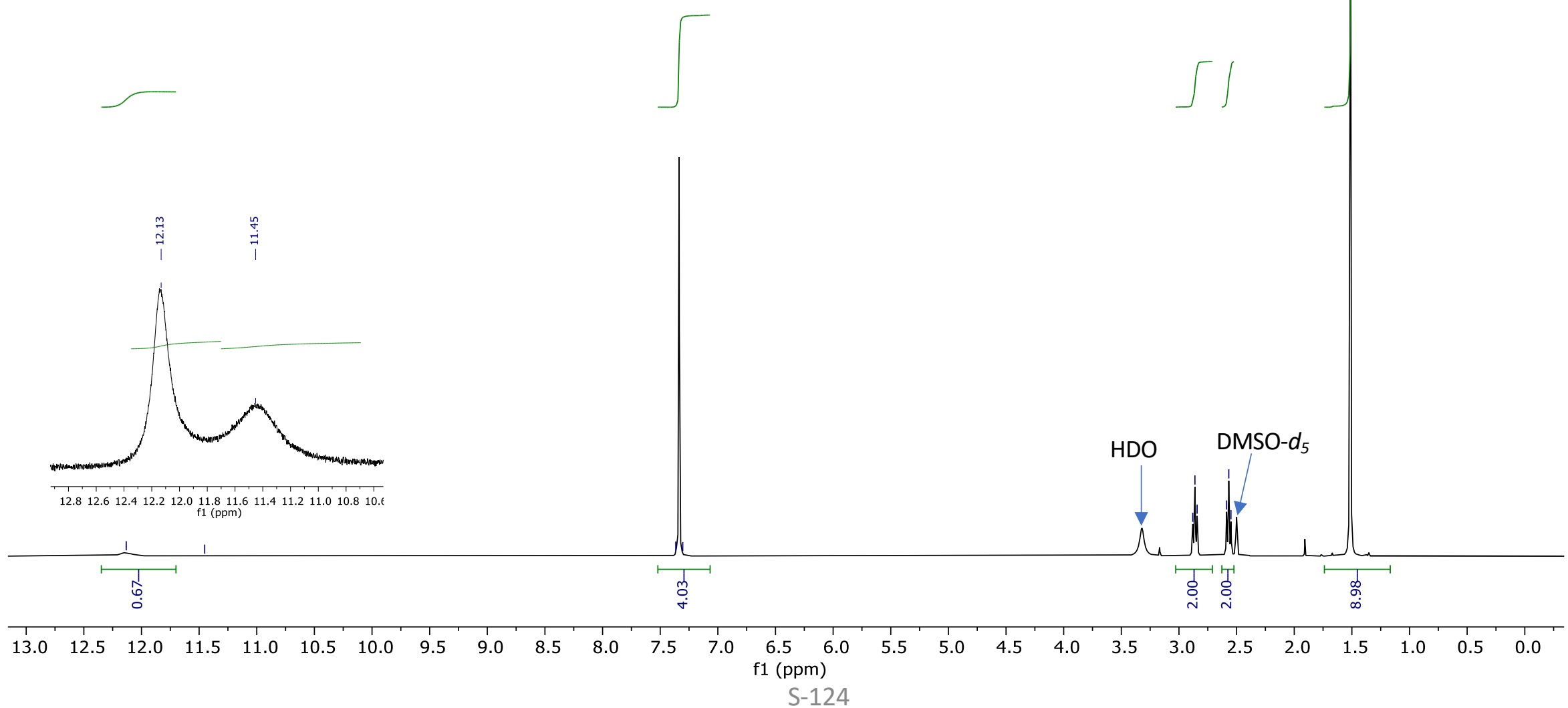



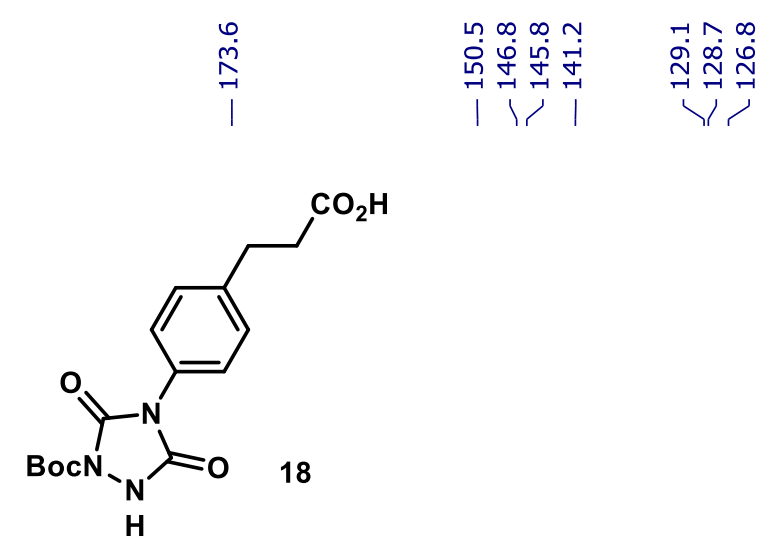

$\stackrel{+}{+}$

$101 \mathrm{MHz}{ }^{13} \mathrm{C}$ NMR Spectrum of compound 18 (recorded in DMSO- $d_{6}$ )

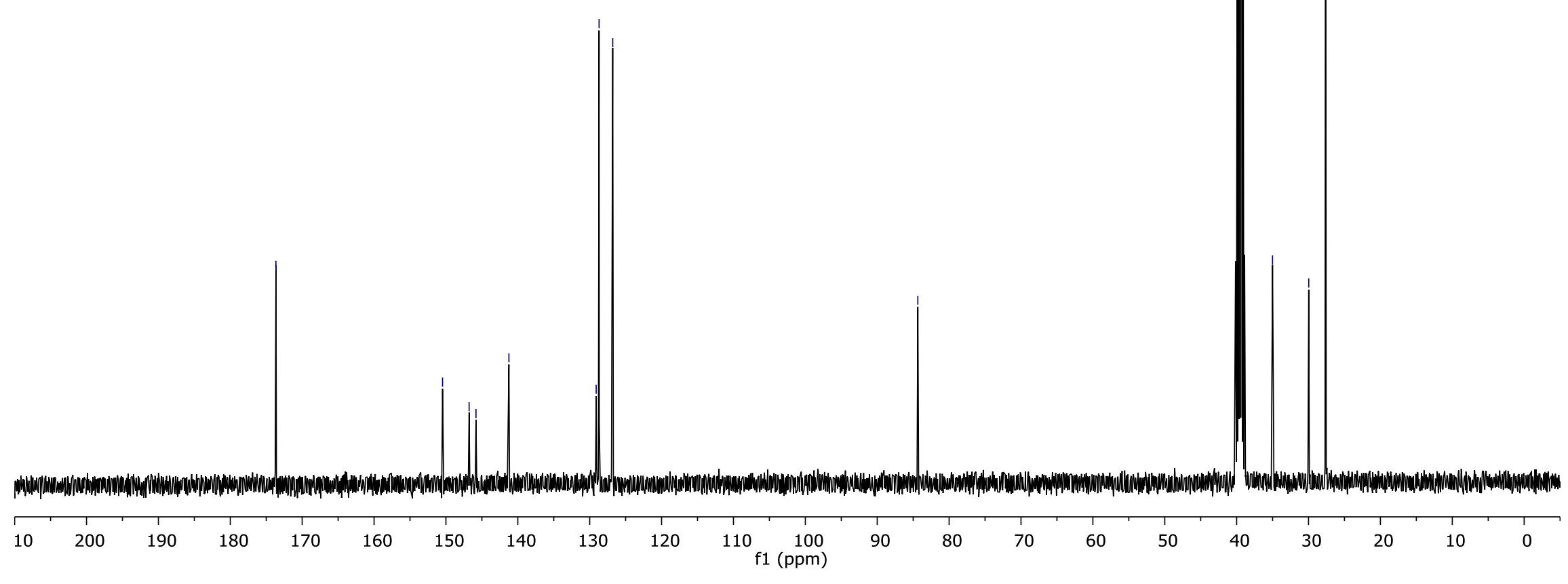




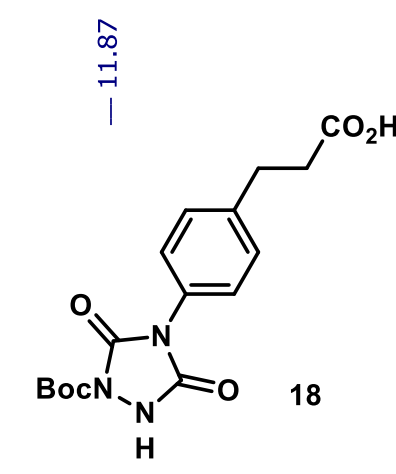

$400 \mathrm{MHz}^{1} \mathrm{H}$ NMR Spectrum of crude 18 derived from di-tert-butyl dicarbonate (recorded in DMSO- $d_{6}$ )

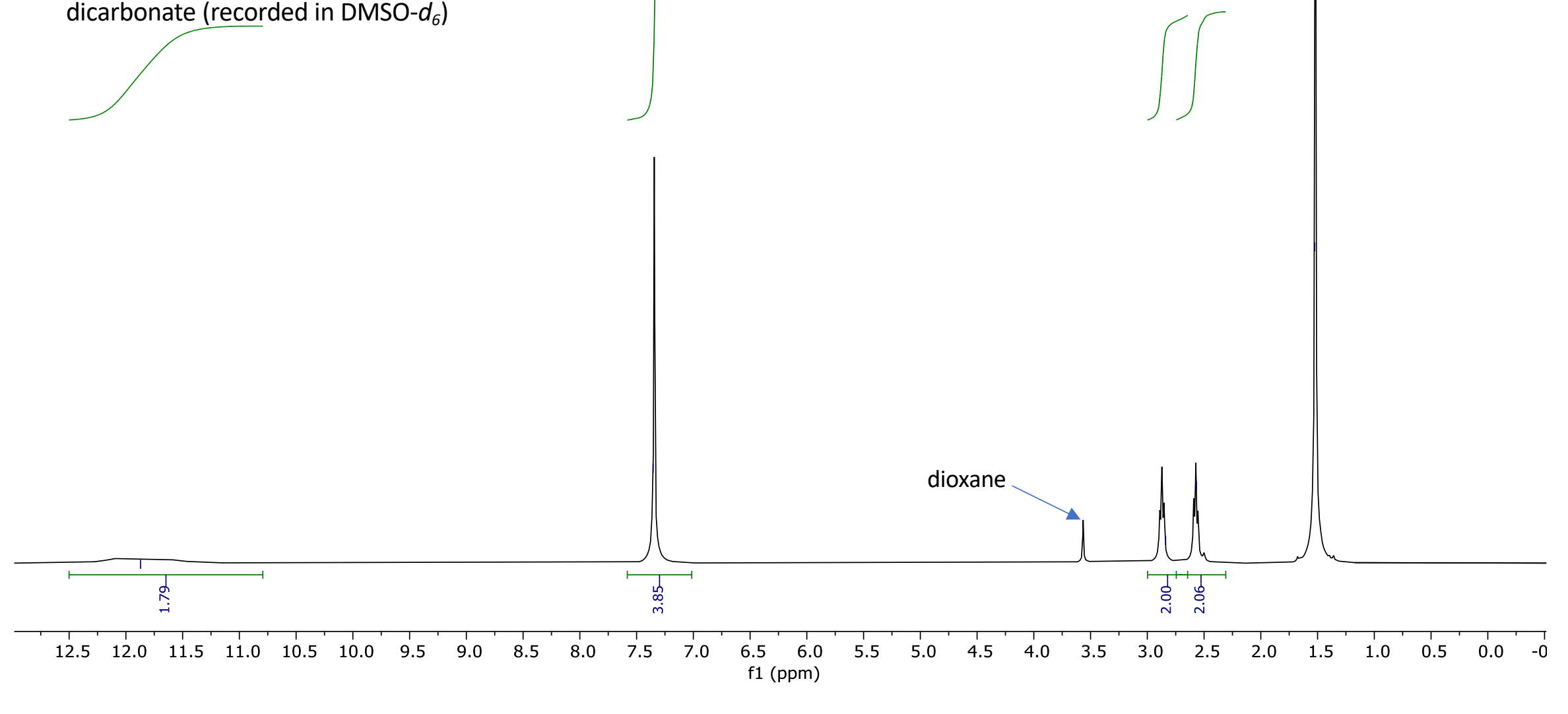




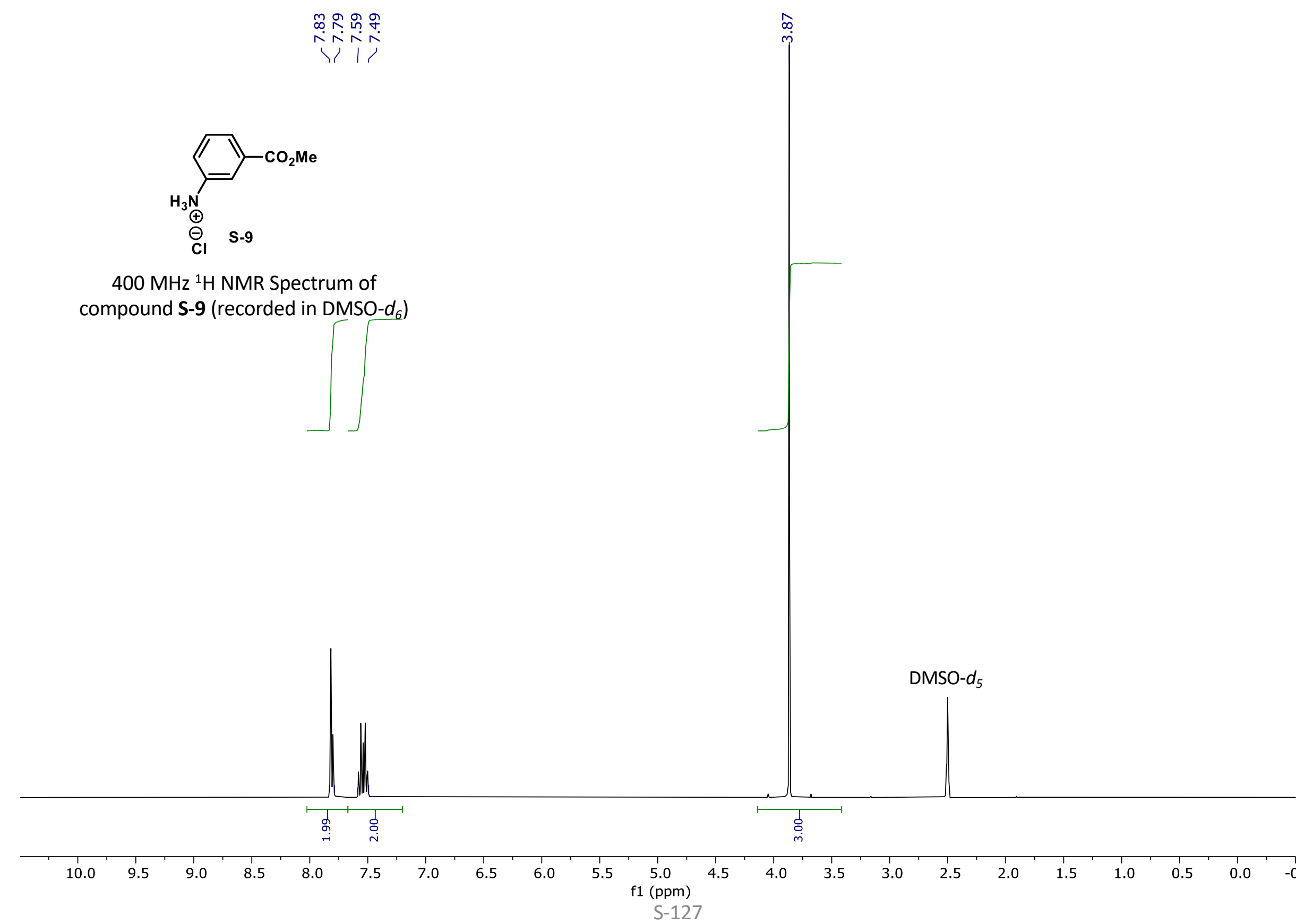




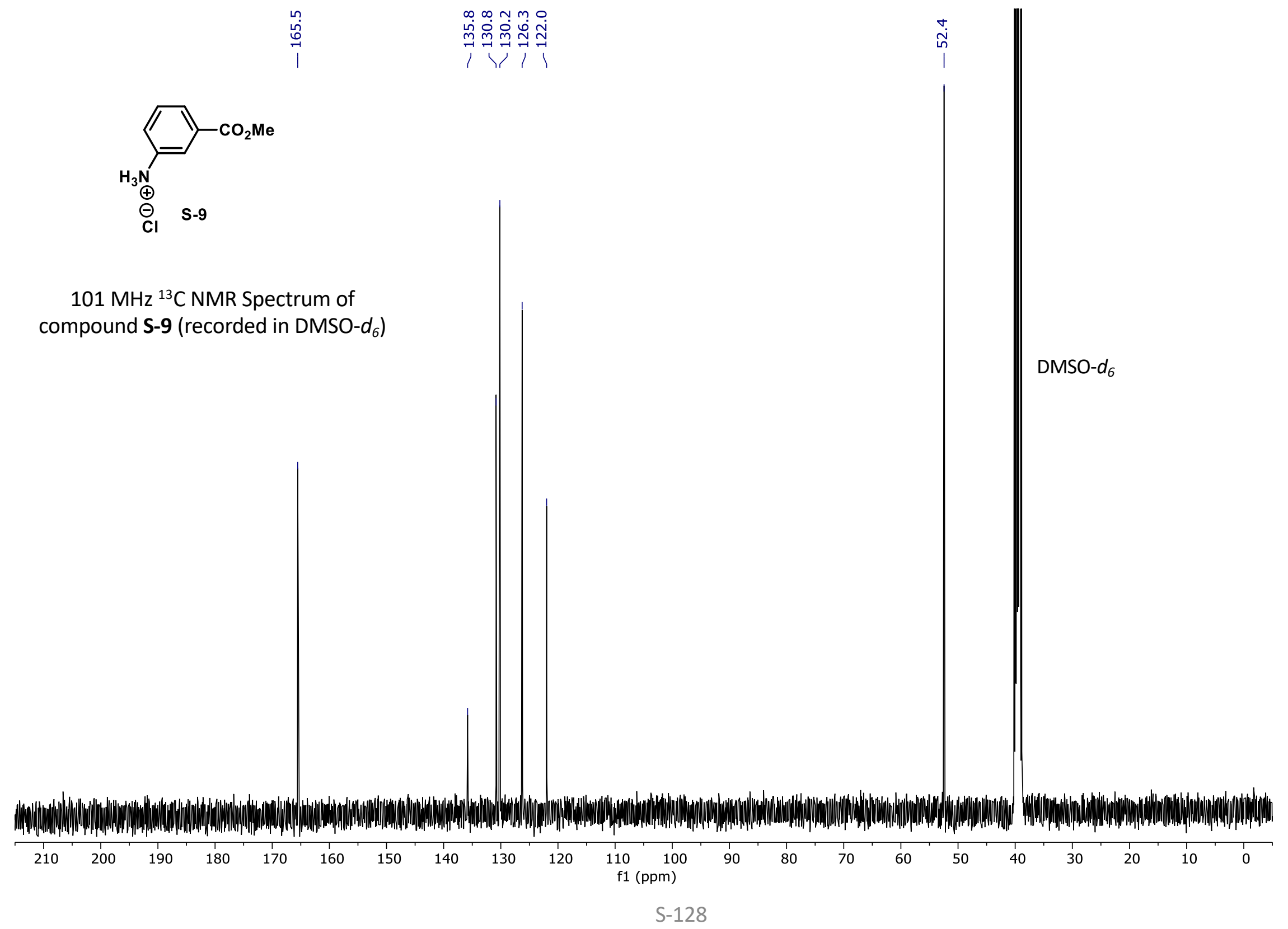




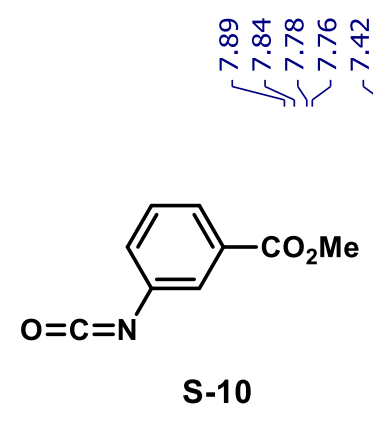

$400 \mathrm{MHz}^{1} \mathrm{H}$ NMR Spectrum of compound S-10 (recorded in $\mathrm{CDCl}_{3}$ )

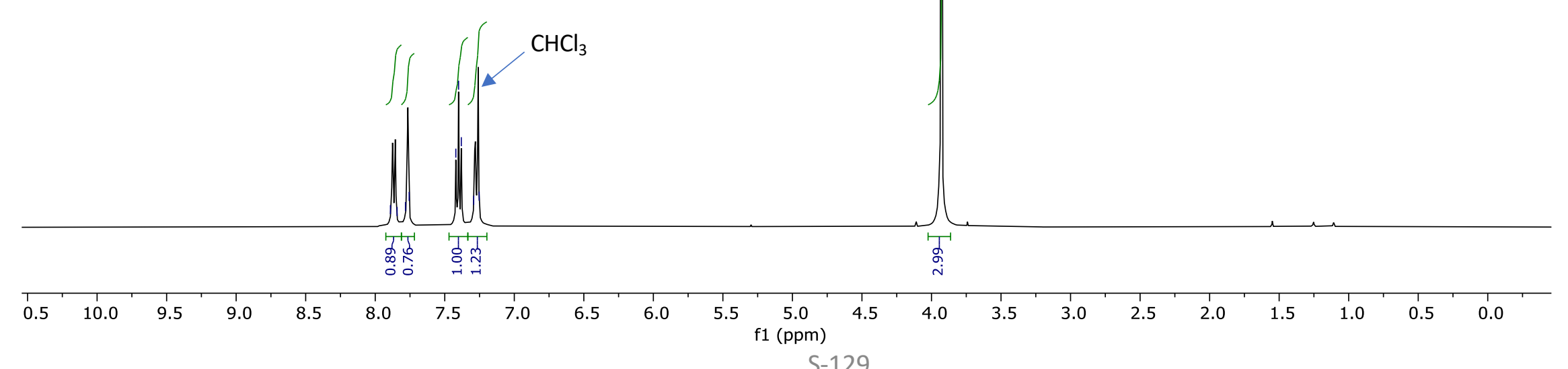




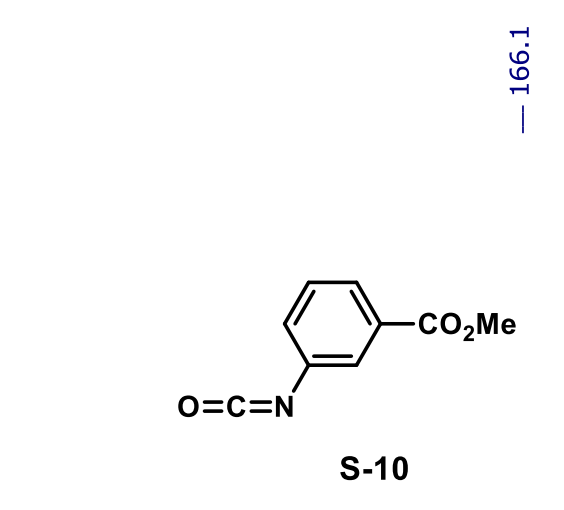

至

$101 \mathrm{MHz}{ }^{13} \mathrm{C}$ NMR Spectrum of compound S-10 (recorded in $\mathrm{CDCl}_{3}$ )

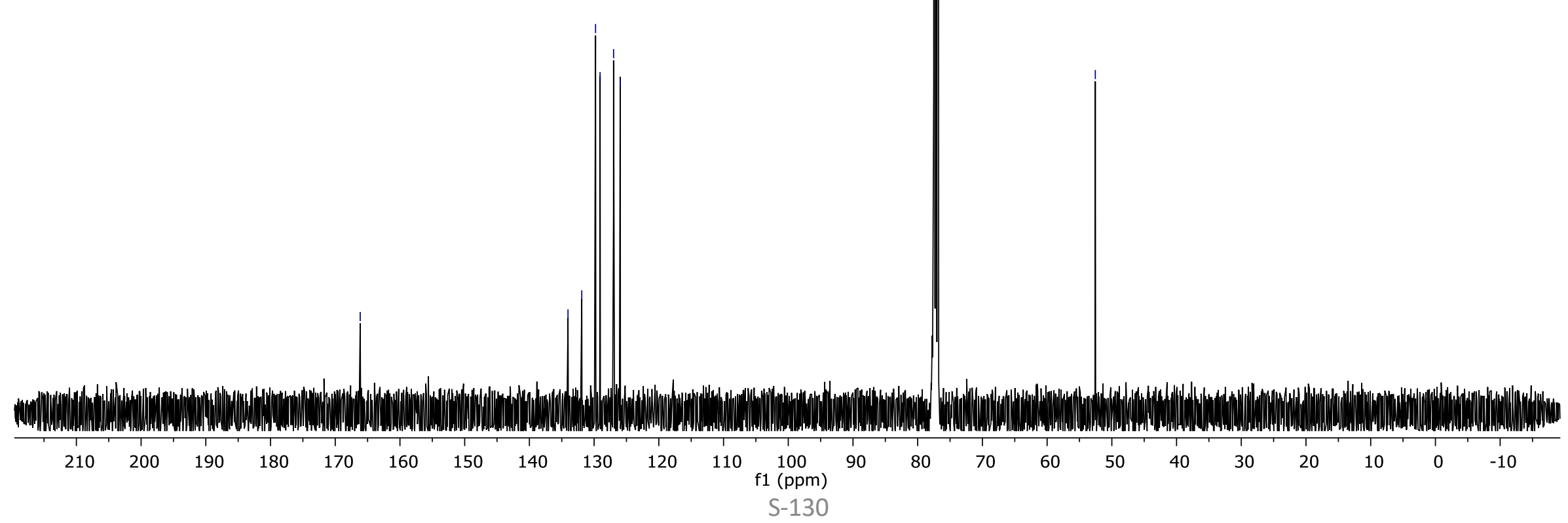




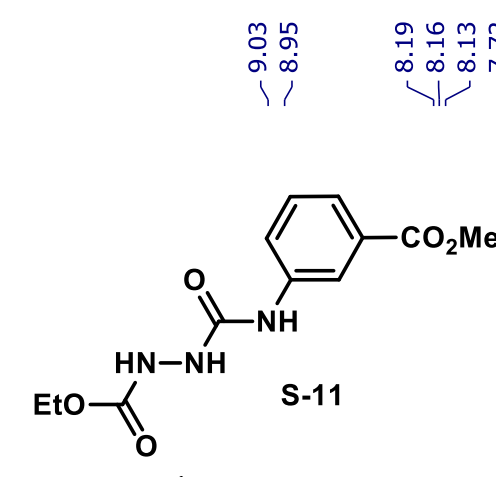

$400 \mathrm{MHz}^{1} \mathrm{H}$ NMR Spectrum of compound S-11 (recorded in DMSO- $d_{6}$ )

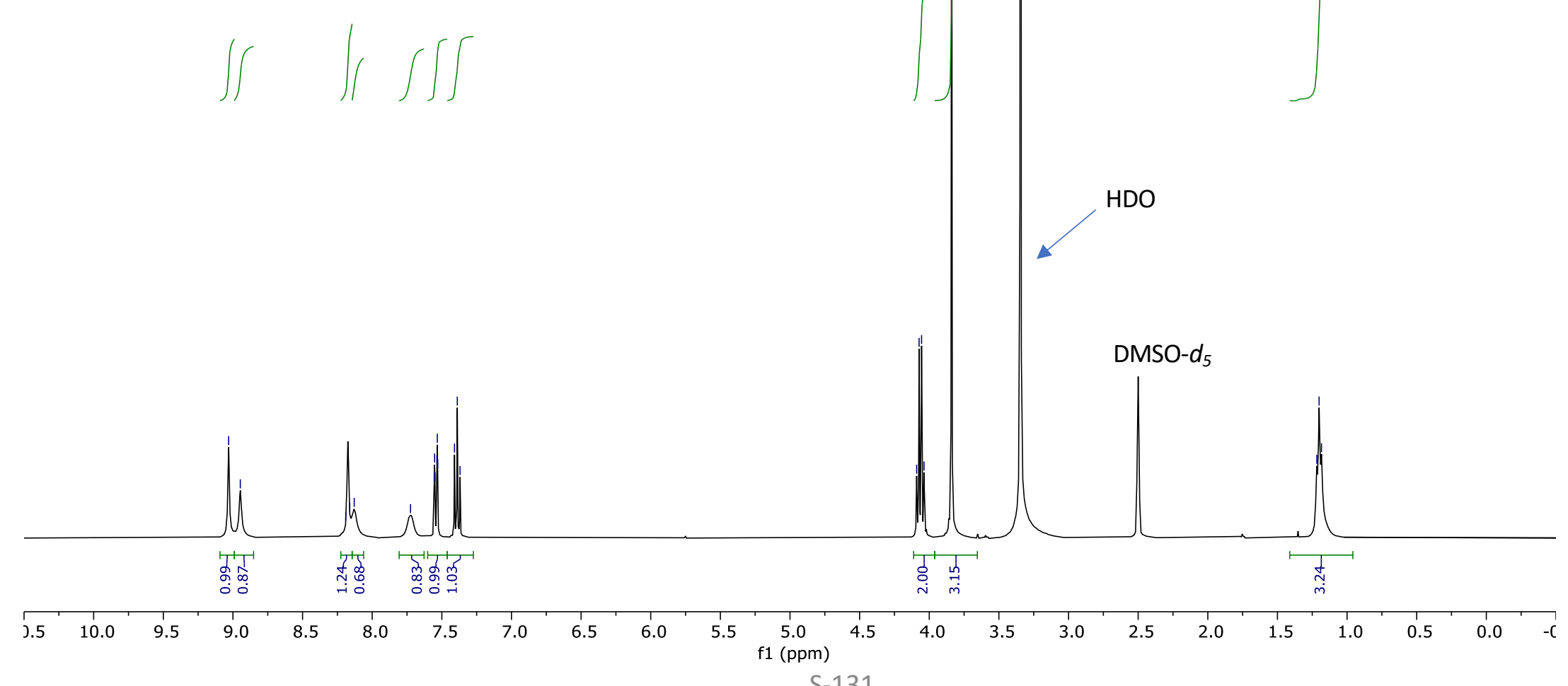




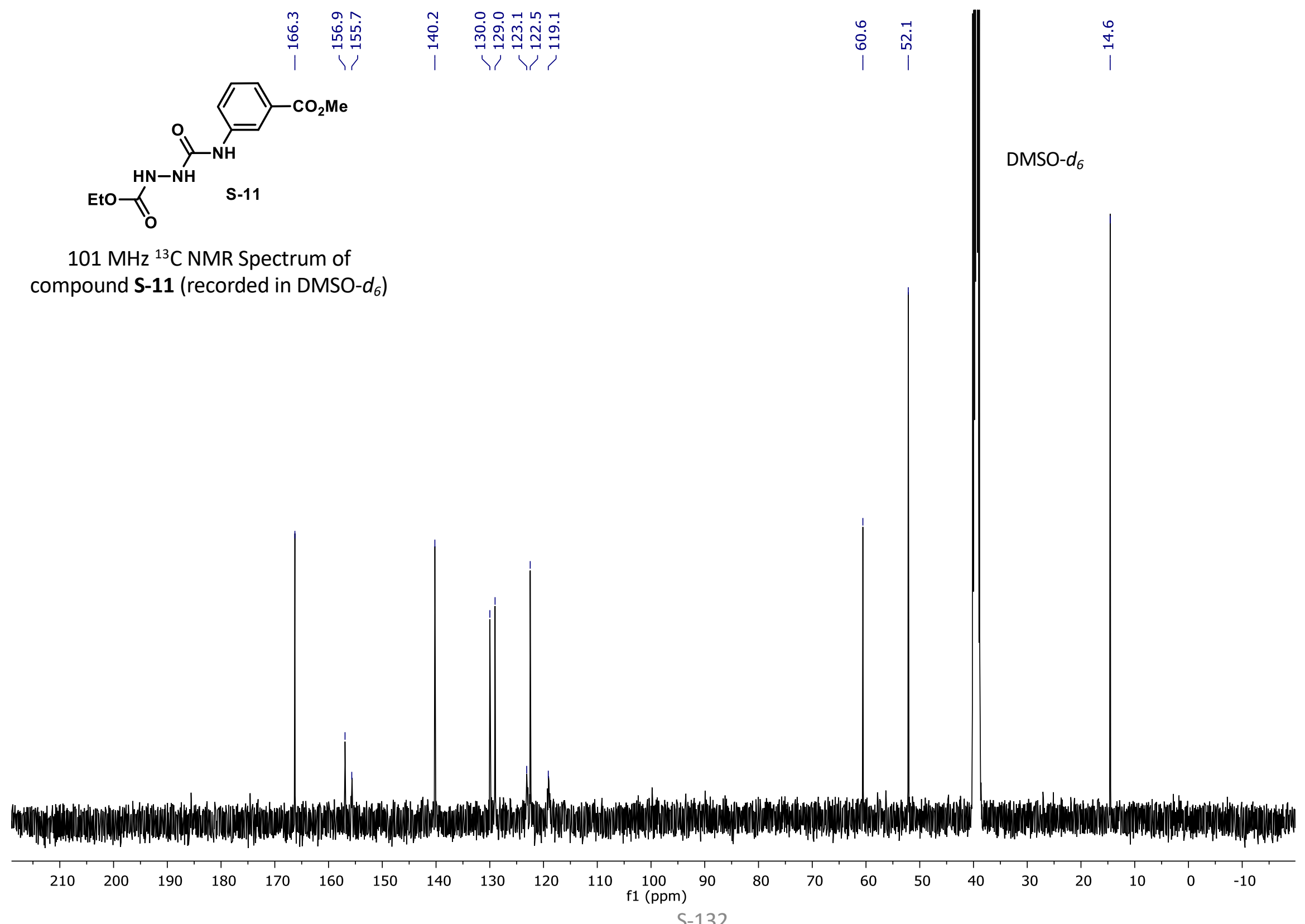




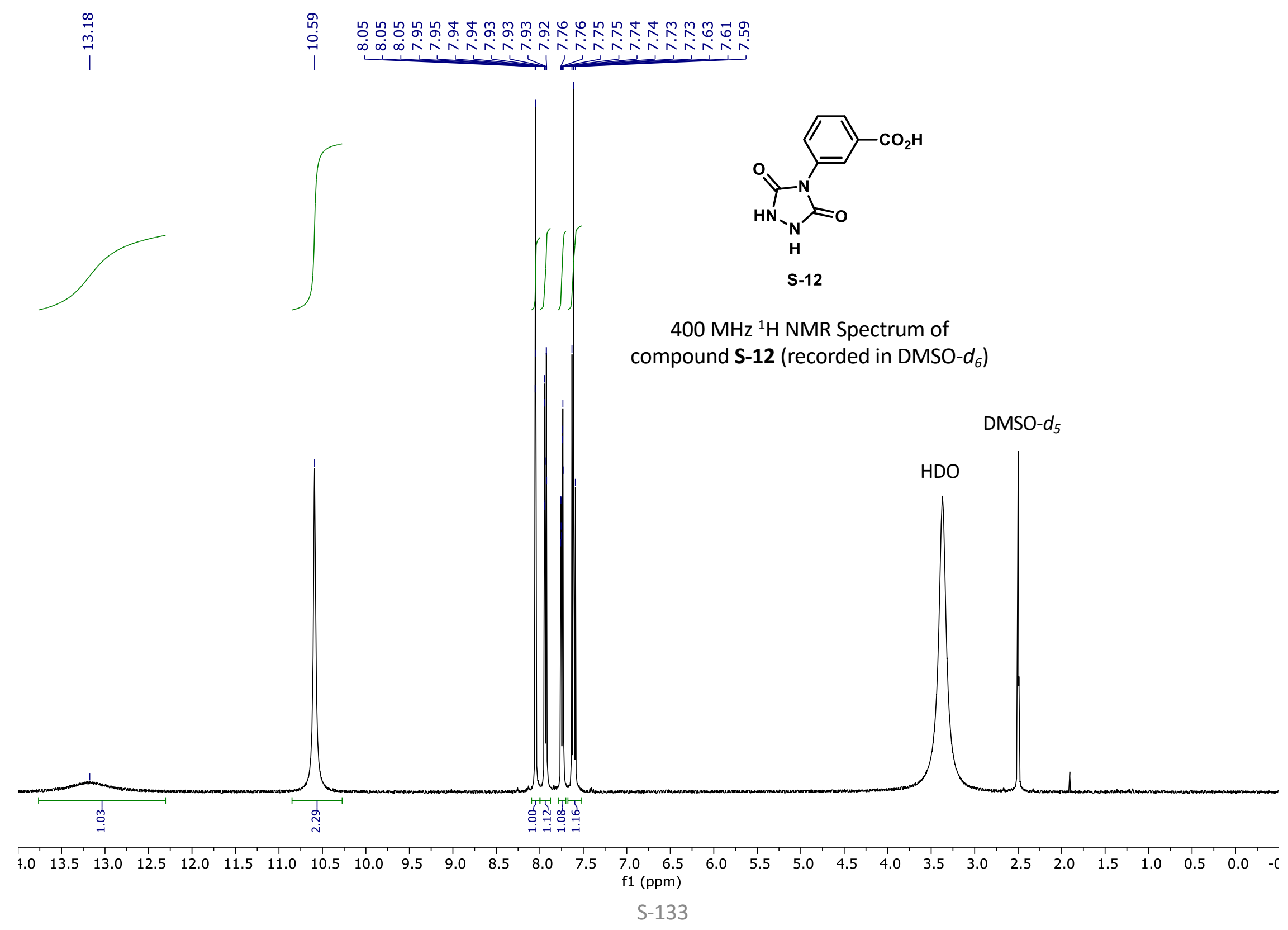




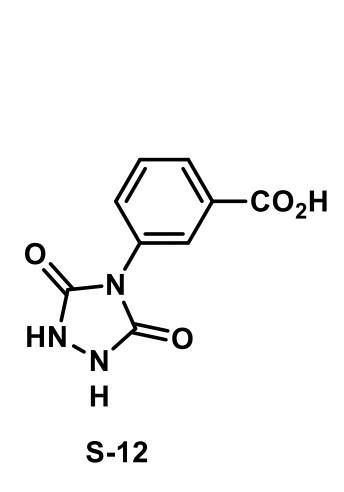

$101 \mathrm{MHz}{ }^{13} \mathrm{C}$ NMR Spectrum of zompound S-12 (recorded in DMSO- $d_{6}$ )

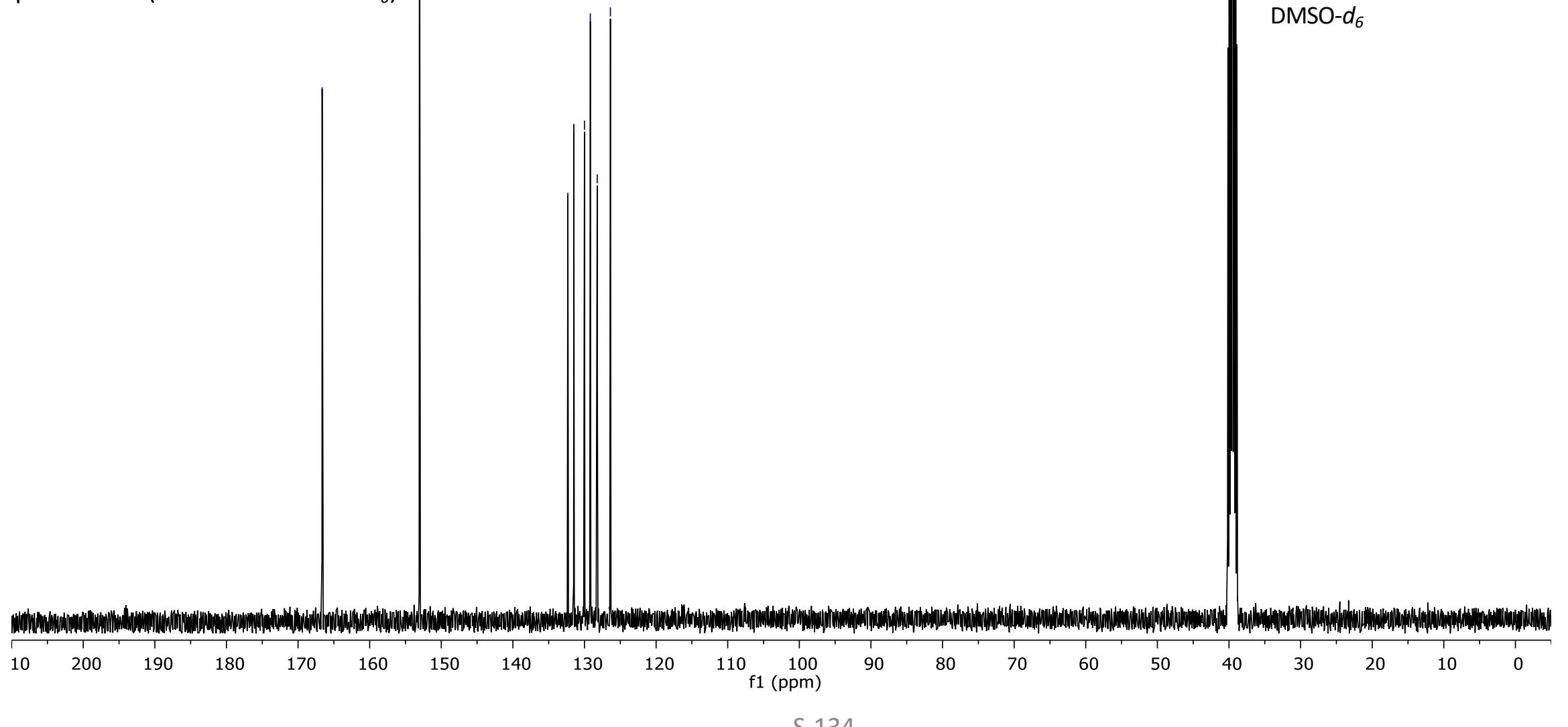




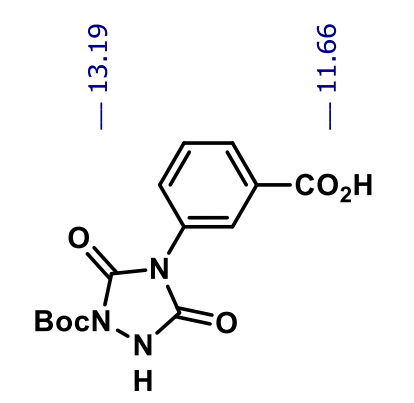

23

$400 \mathrm{MHz}{ }^{1} \mathrm{H}$ NMR Spectrum of compound 23 (recorded in DMSO- $d_{6}$ )
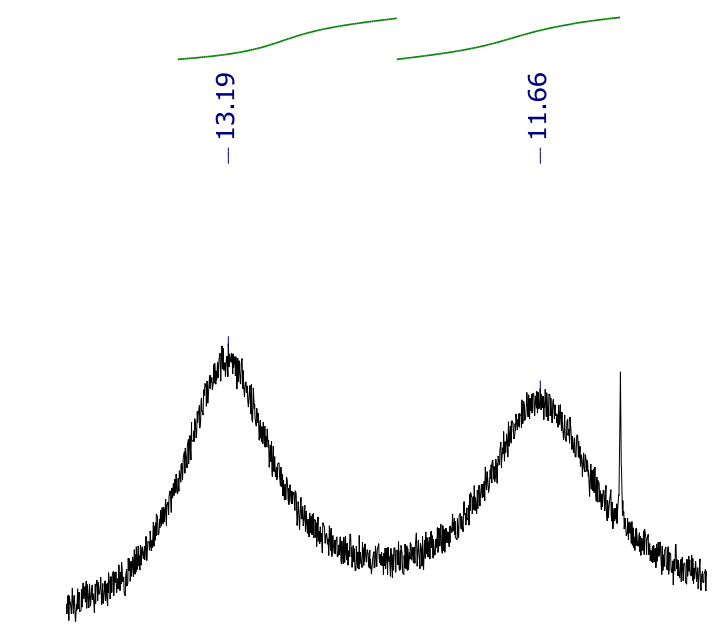

$\begin{array}{lllllllllllllllllll}13.8 & 13.6 & 13.4 & 13.2 & 13.9 & 12.8 & 12.6 & 12.4 & 12.2 & 12.0 & 1 & 1.8 & 11.6 & 11.4 & 1.2 & 11.0\end{array}$

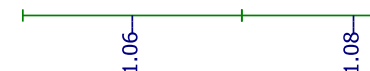
$\stackrel{\infty}{\rightarrow}$ 


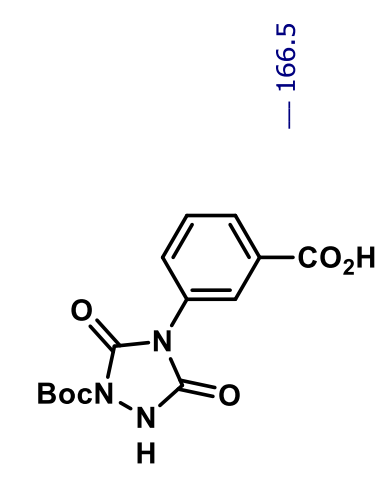

23

$101 \mathrm{MHz}{ }^{13} \mathrm{C}$ NMR Spectrum of

compound 23 (recorded in DMSO- $d_{6}$ )
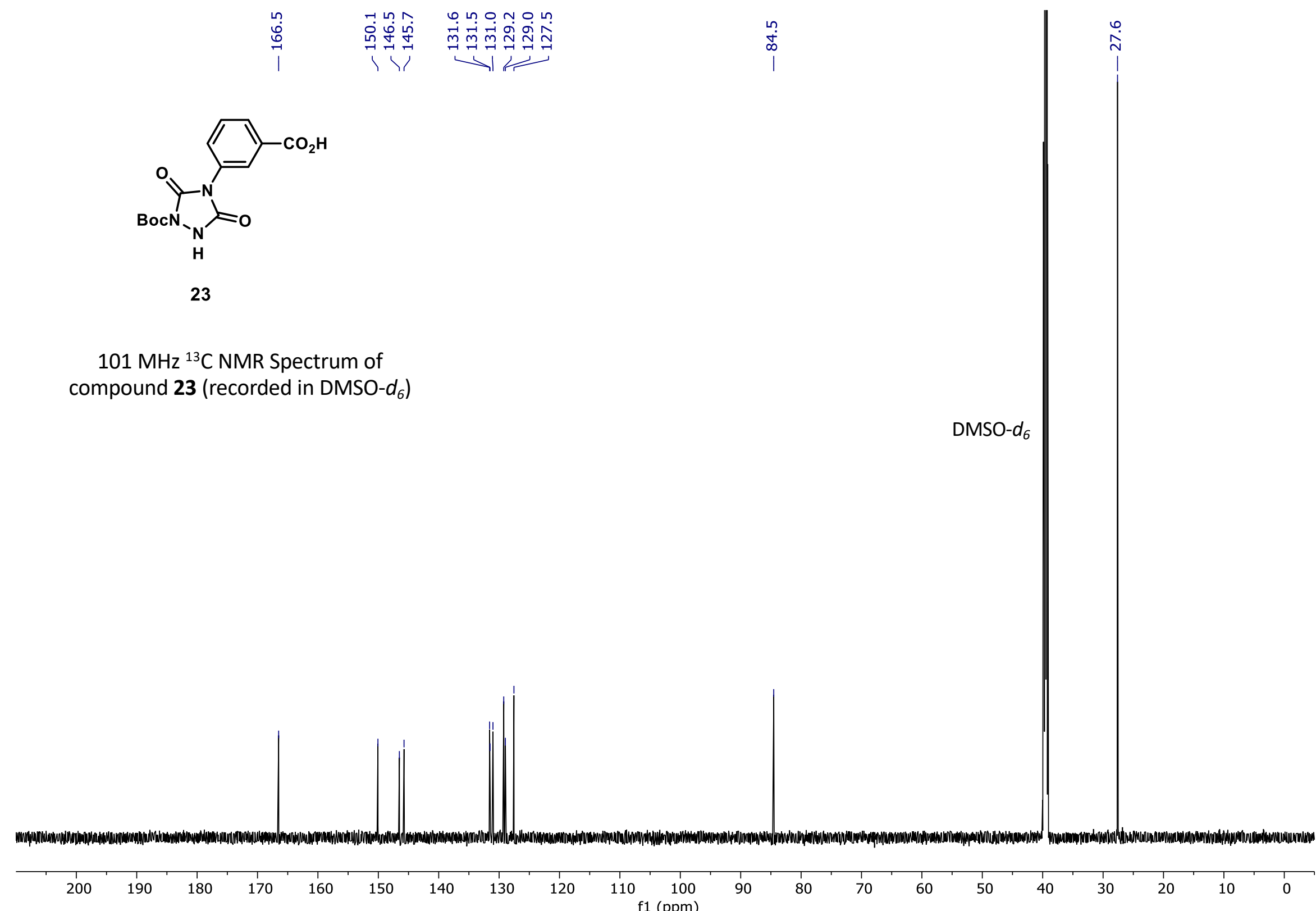


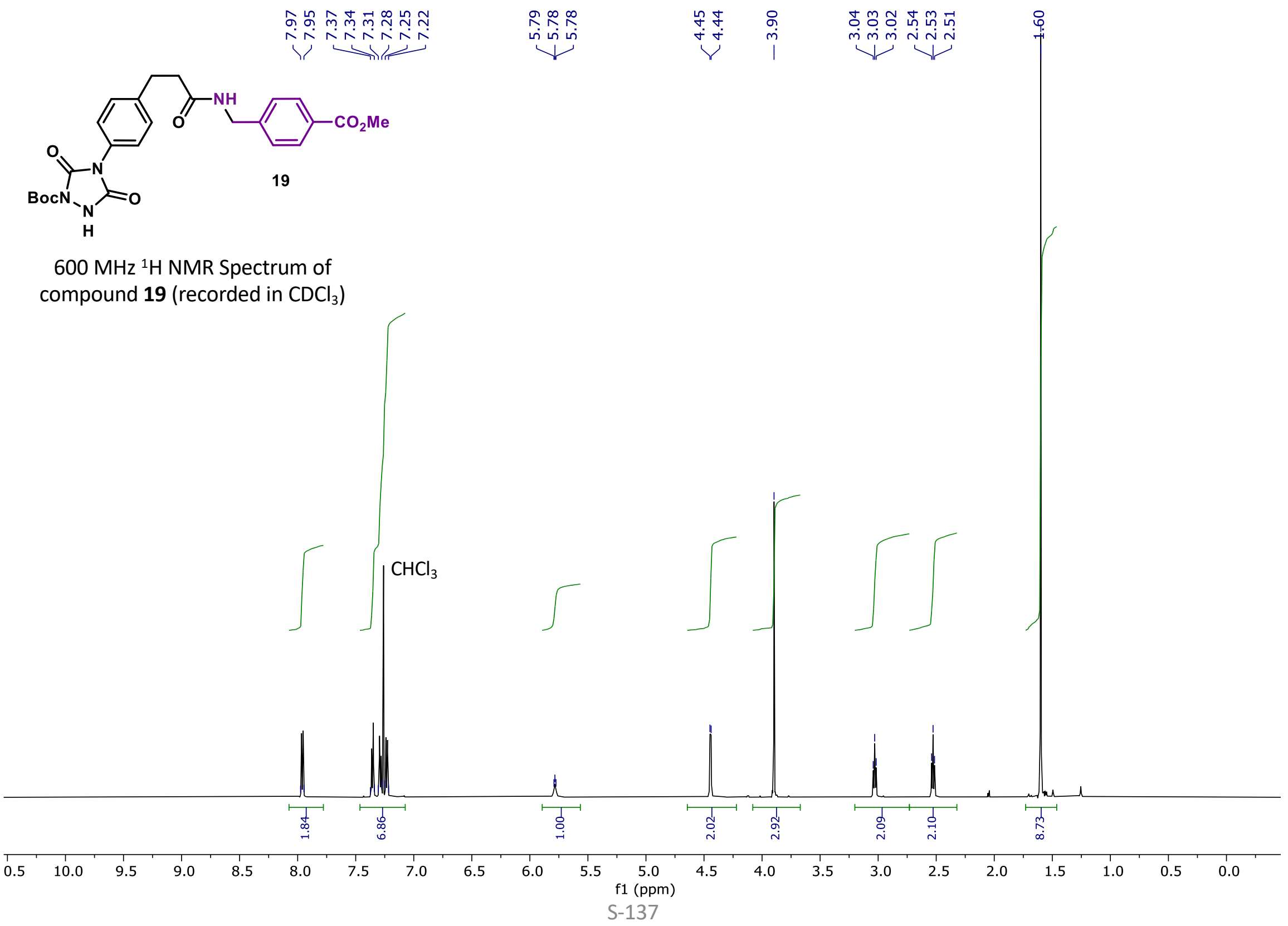




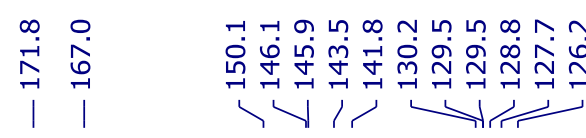

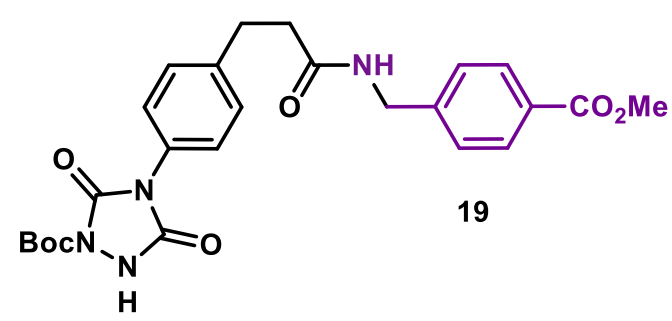

$\mathrm{CDCl}_{3}$

$151 \mathrm{MHz}{ }^{13} \mathrm{C}$ NMR Spectrum of compound 19 (recorded in $\mathrm{CDCl}_{3}$ )

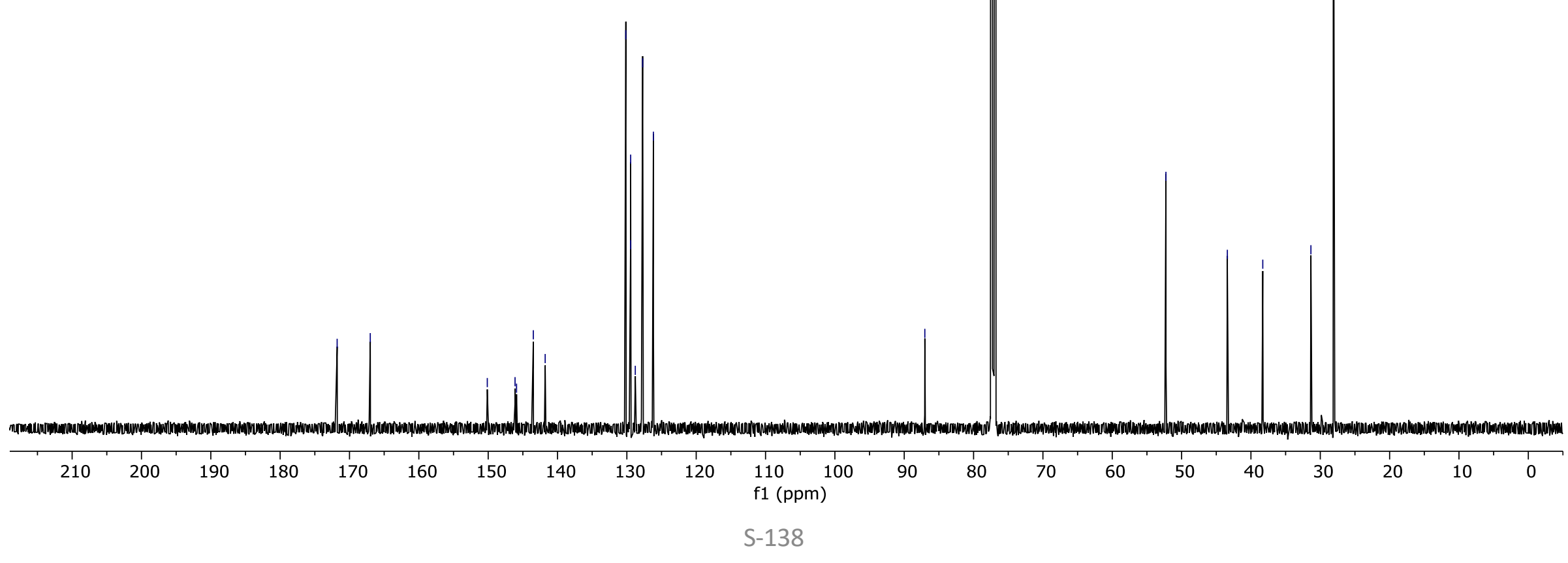




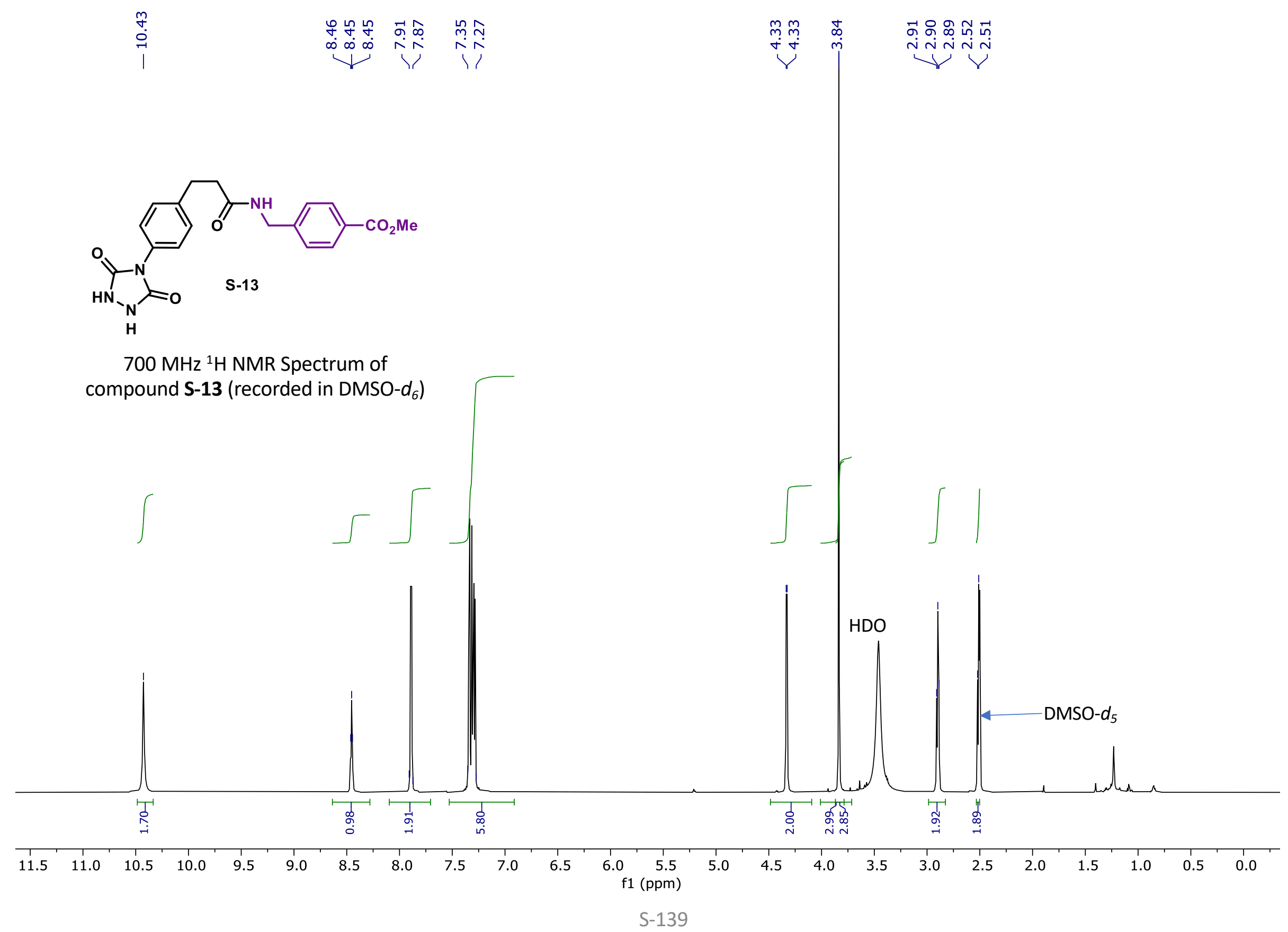




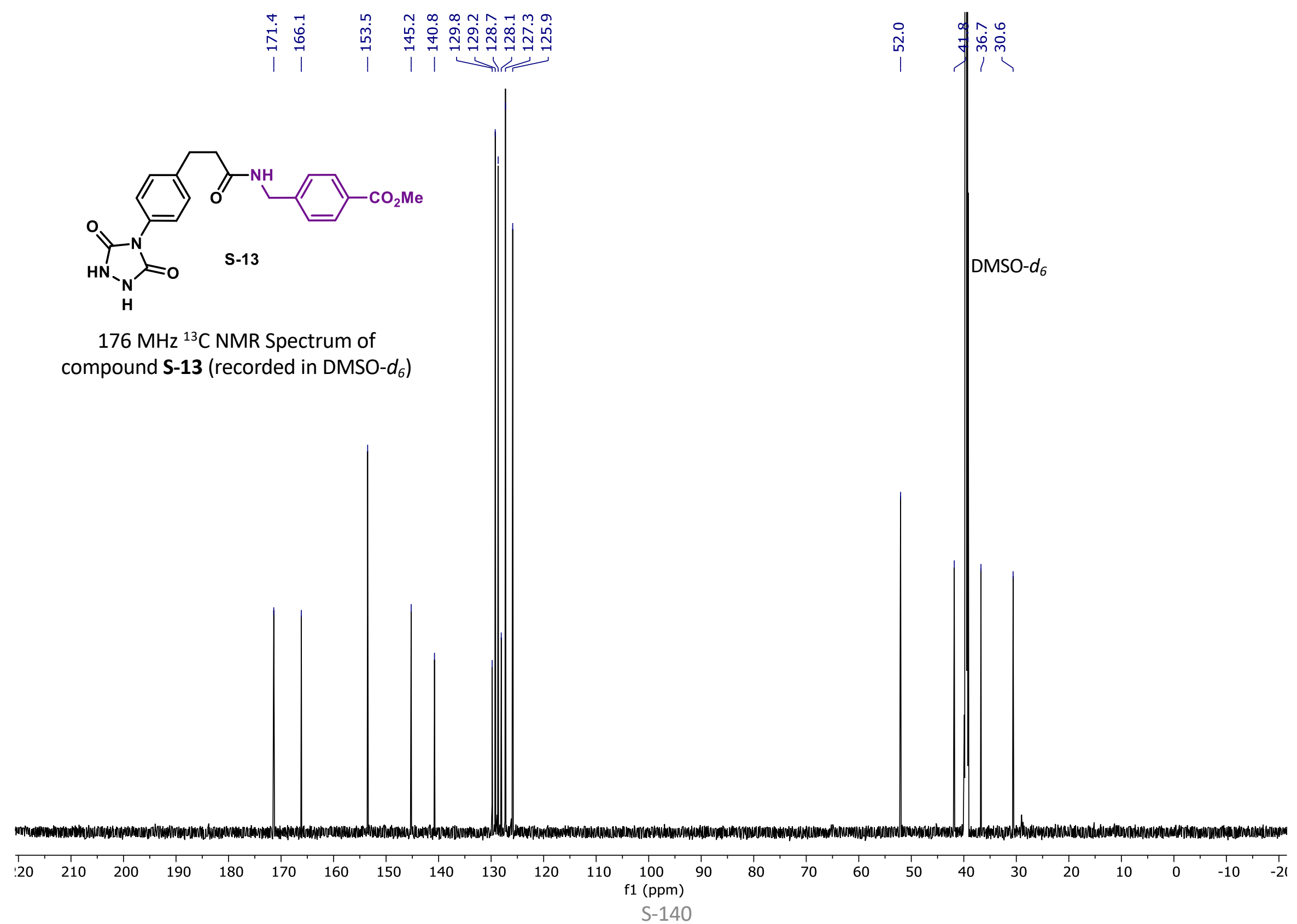




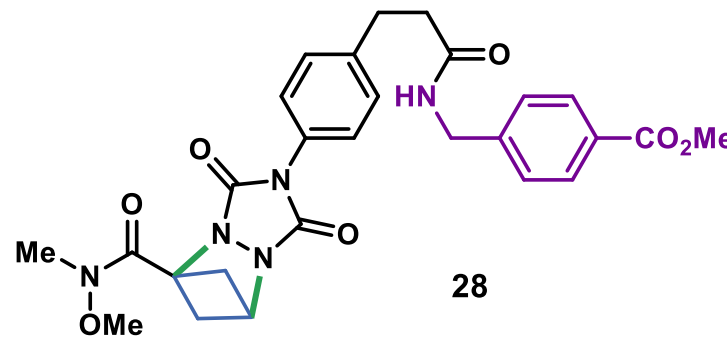

$700 \mathrm{MHz}{ }^{1} \mathrm{H}$ NMR Spectrum of compound $\mathbf{2 8}$ (recorded in $\mathrm{CDCl}_{3}$ )
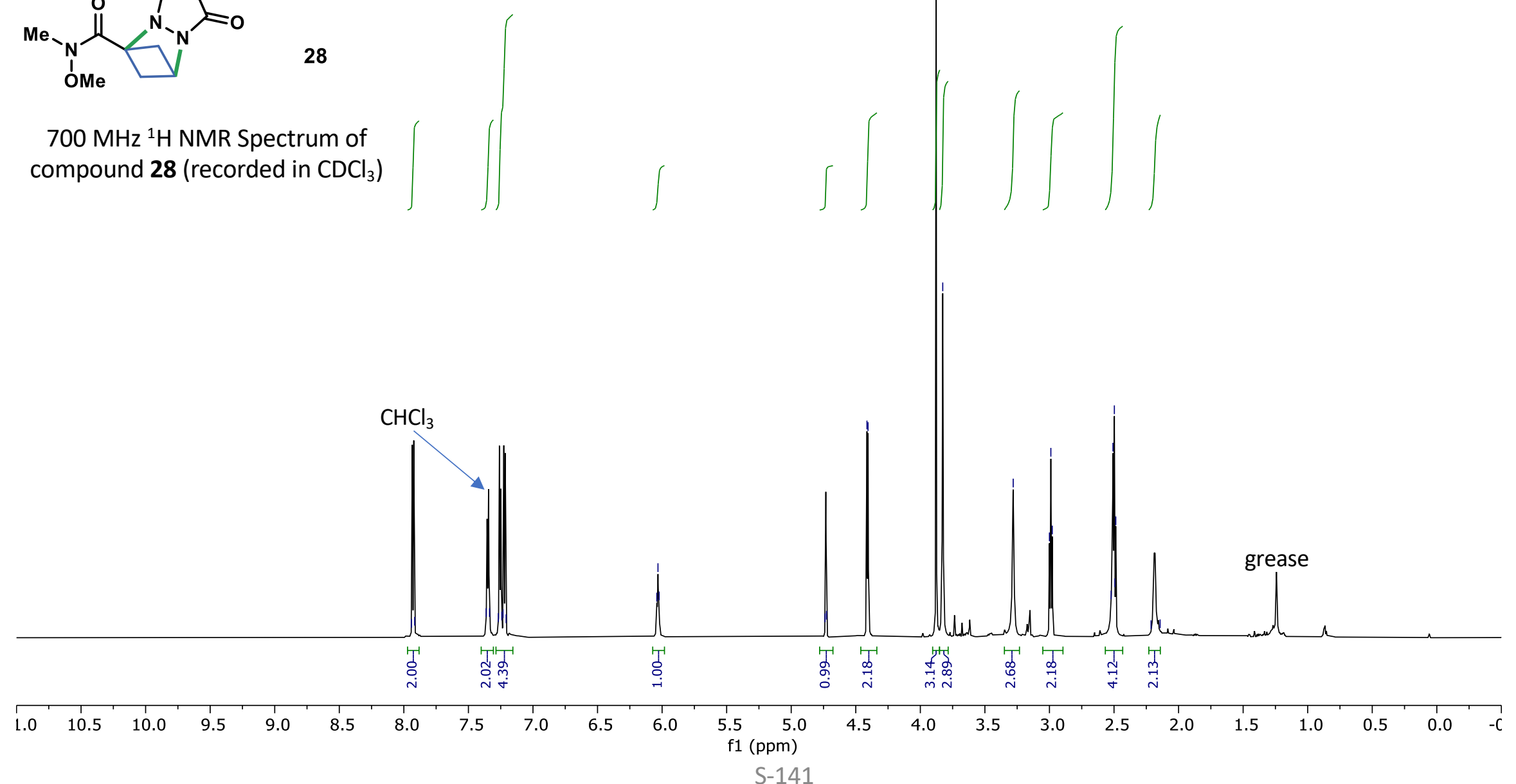


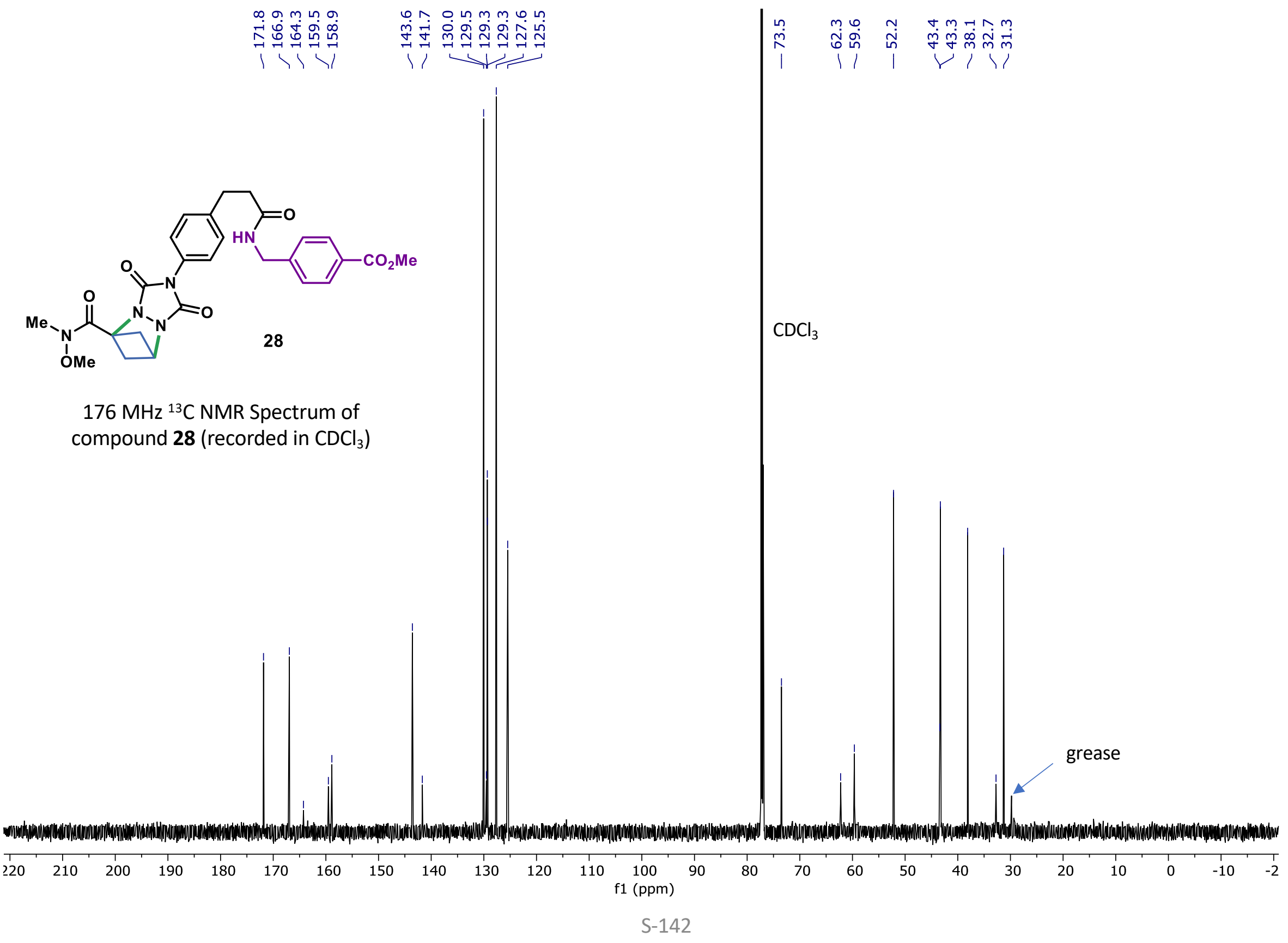




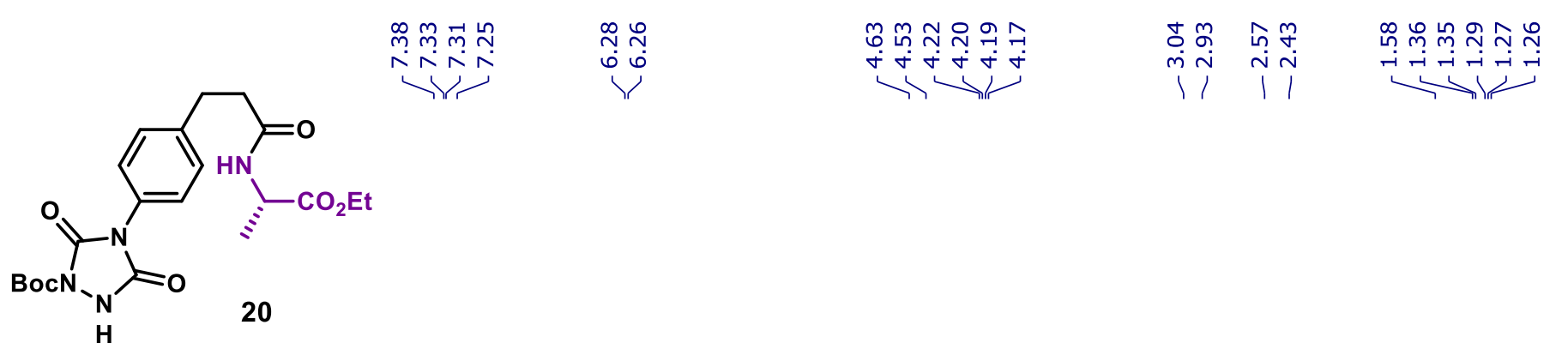

$400 \mathrm{MHz}{ }^{1} \mathrm{H}$ NMR Spectrum of compound $\mathbf{2 0}$ (recorded in $\mathrm{CDCl}_{3}$ )

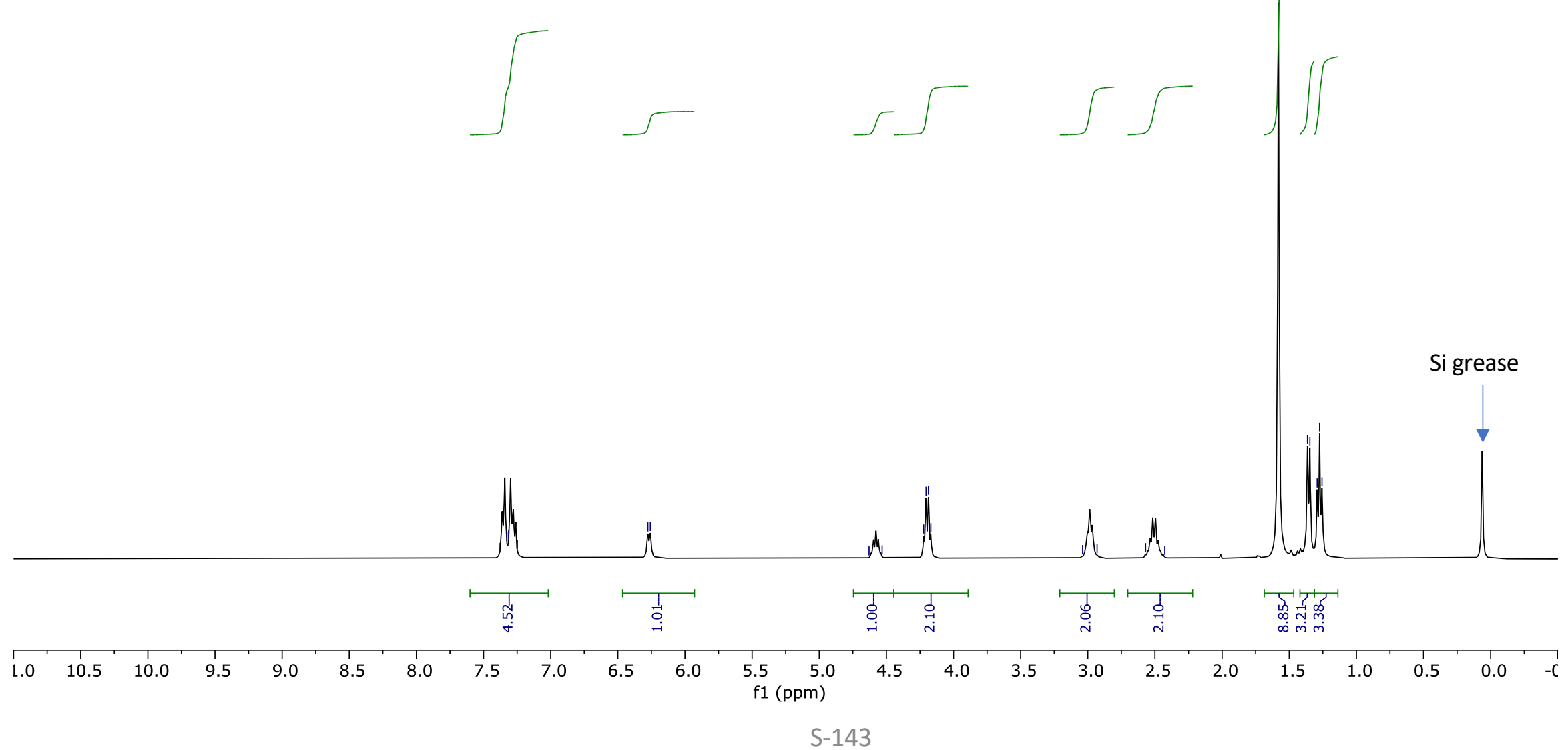




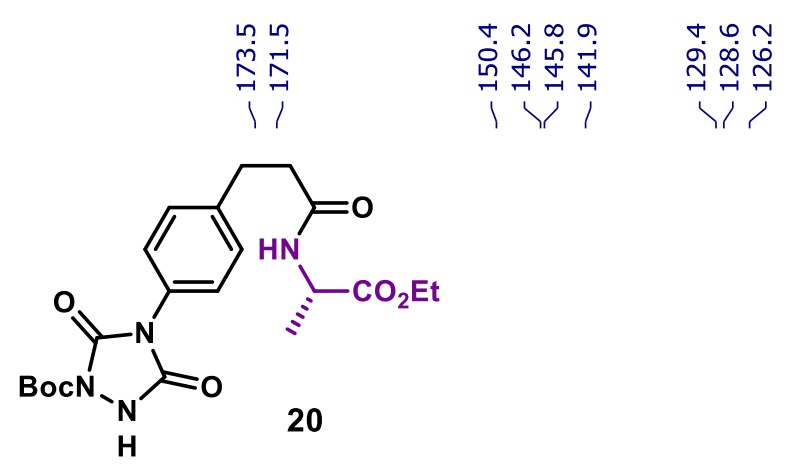

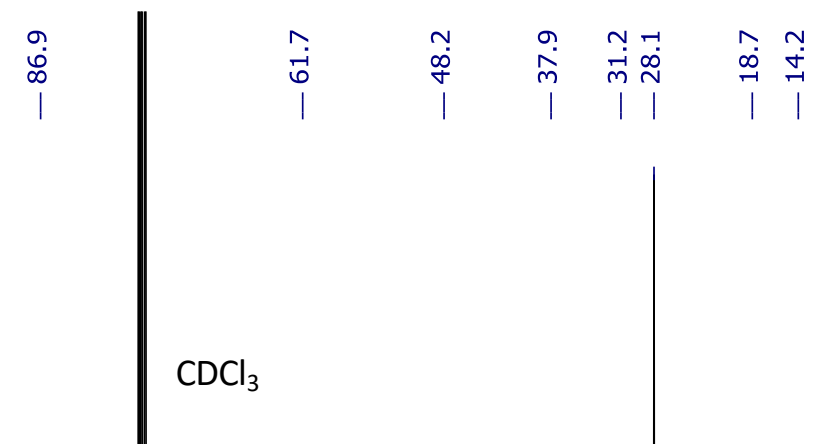

$101 \mathrm{MHz}{ }^{13} \mathrm{C}$ NMR Spectrum of compound $\mathbf{2 0}$ (recorded in $\mathrm{CDCl}_{3}$ )

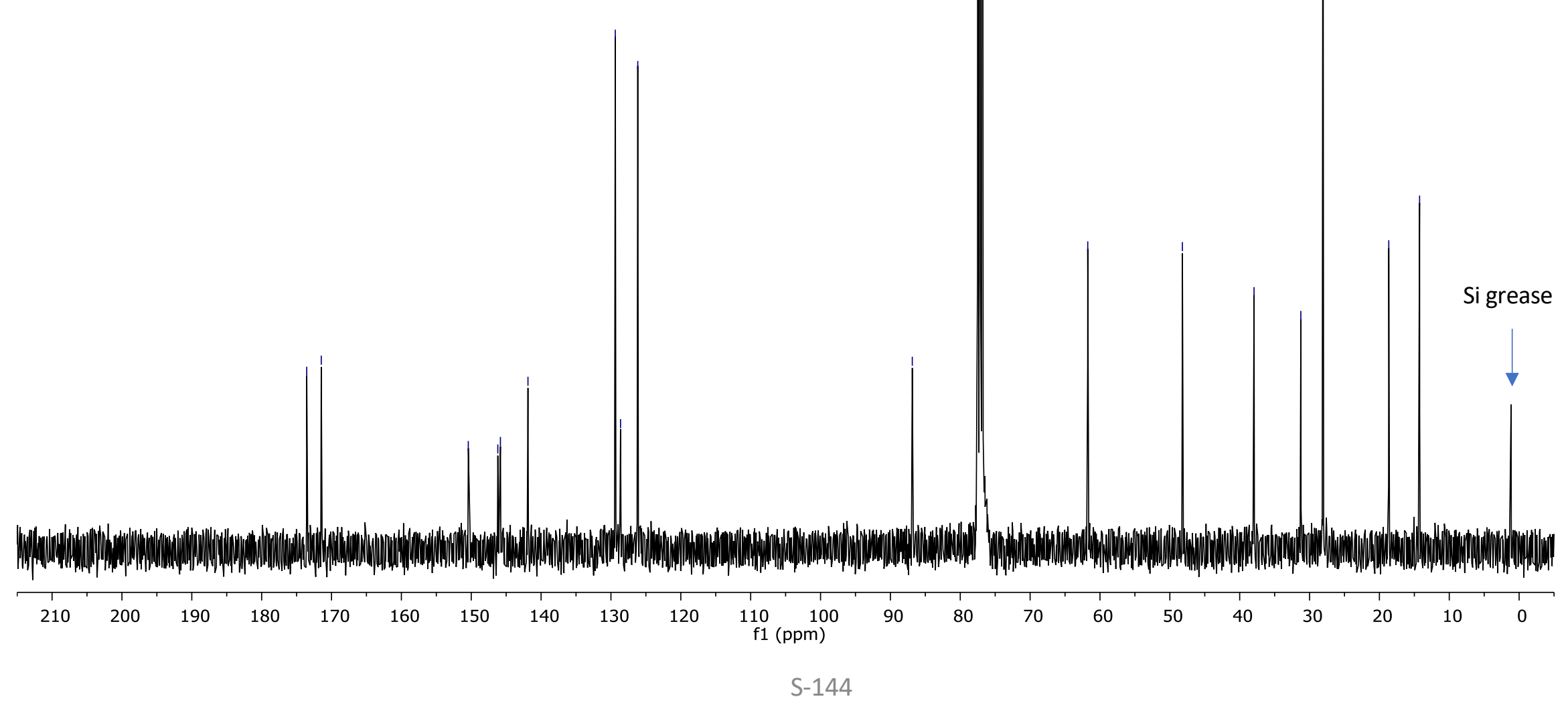



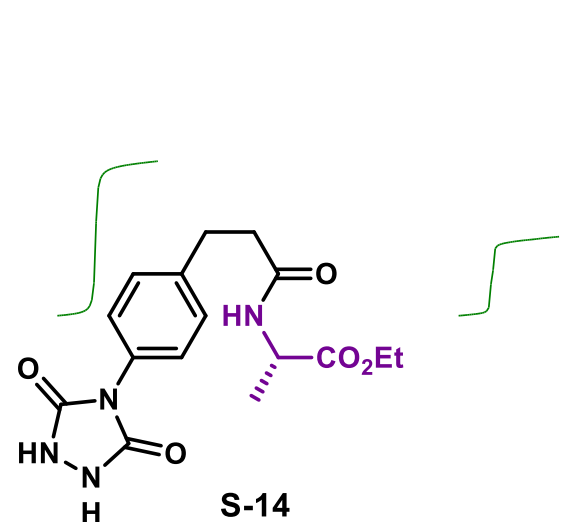

$400 \mathrm{MHz}{ }^{1} \mathrm{H}$ NMR Spectrum of compound S-14 (recorded in DMSO- $d_{6}$ )

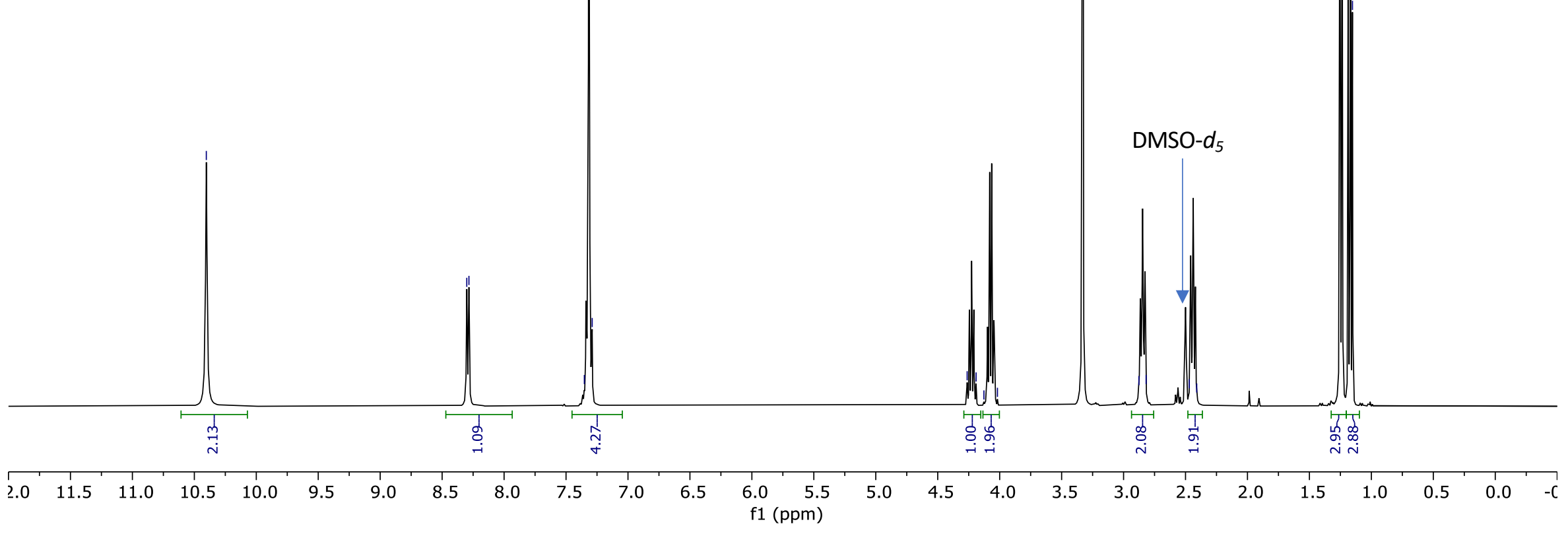




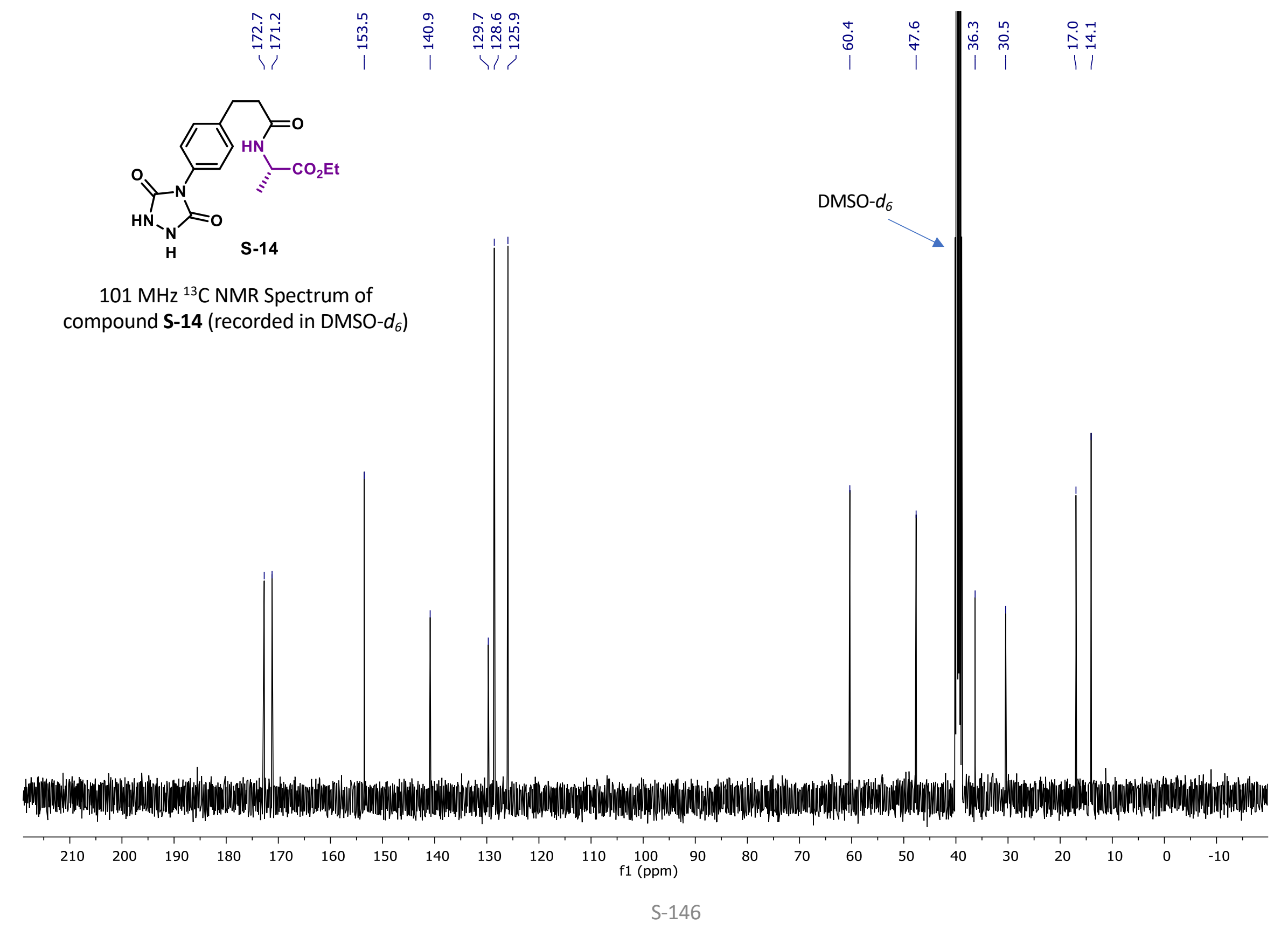




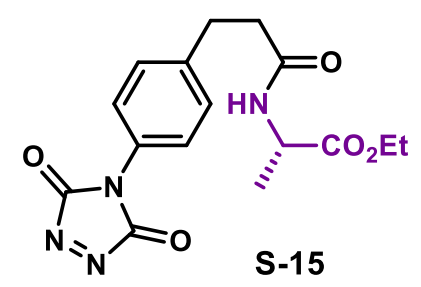

$400 \mathrm{MHz}{ }^{1} \mathrm{H}$ NMR Spectrum of crude reaction material obtained on compound S-15 (recorded in $\mathrm{CDCl}_{3}$ )

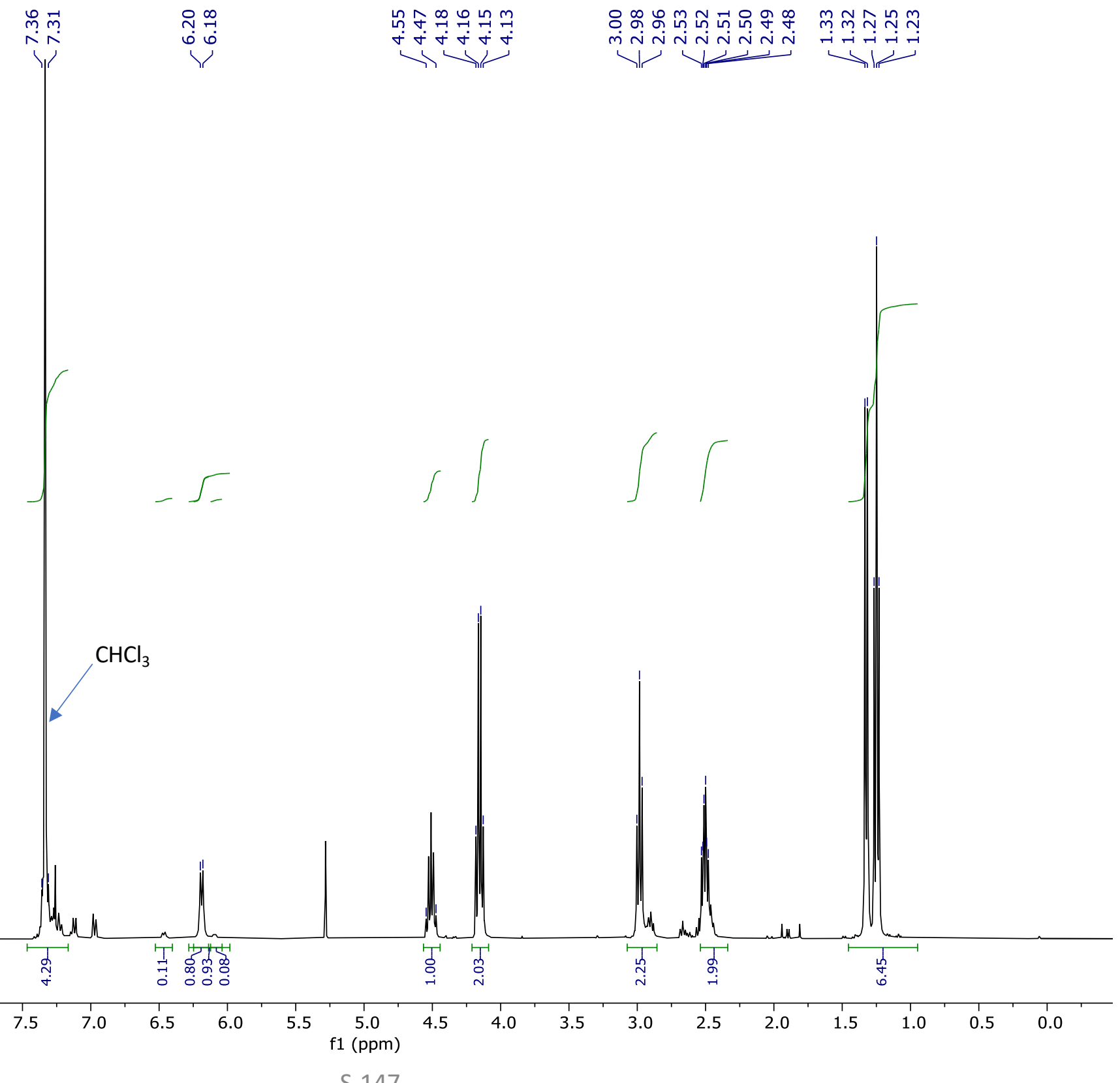




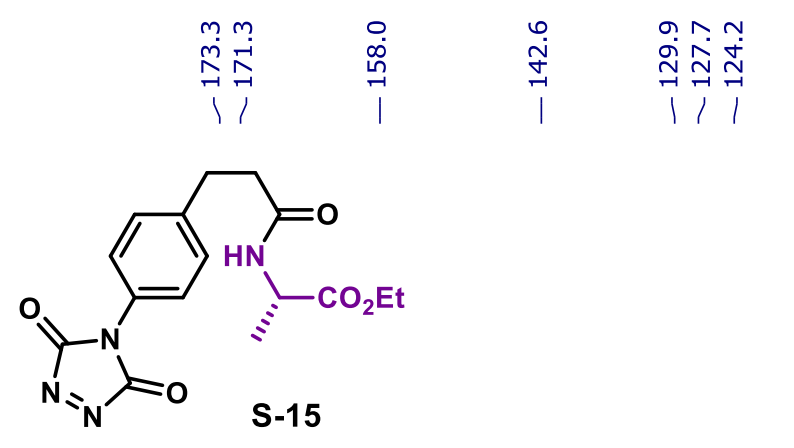

$\begin{array}{cccccc}\hat{i} & \stackrel{0}{\infty} & \stackrel{0}{i} & 0 & \stackrel{n}{\infty} & \stackrel{\infty}{ \pm} \\ 1 & 1 & 1 & \mid & \mid & 1\end{array}$

$101 \mathrm{MHz}{ }^{13} \mathrm{C}$ NMR Spectrum of crude reaction material obtained on compound S-15 (recorded in $\mathrm{CDCl}_{3}$ )

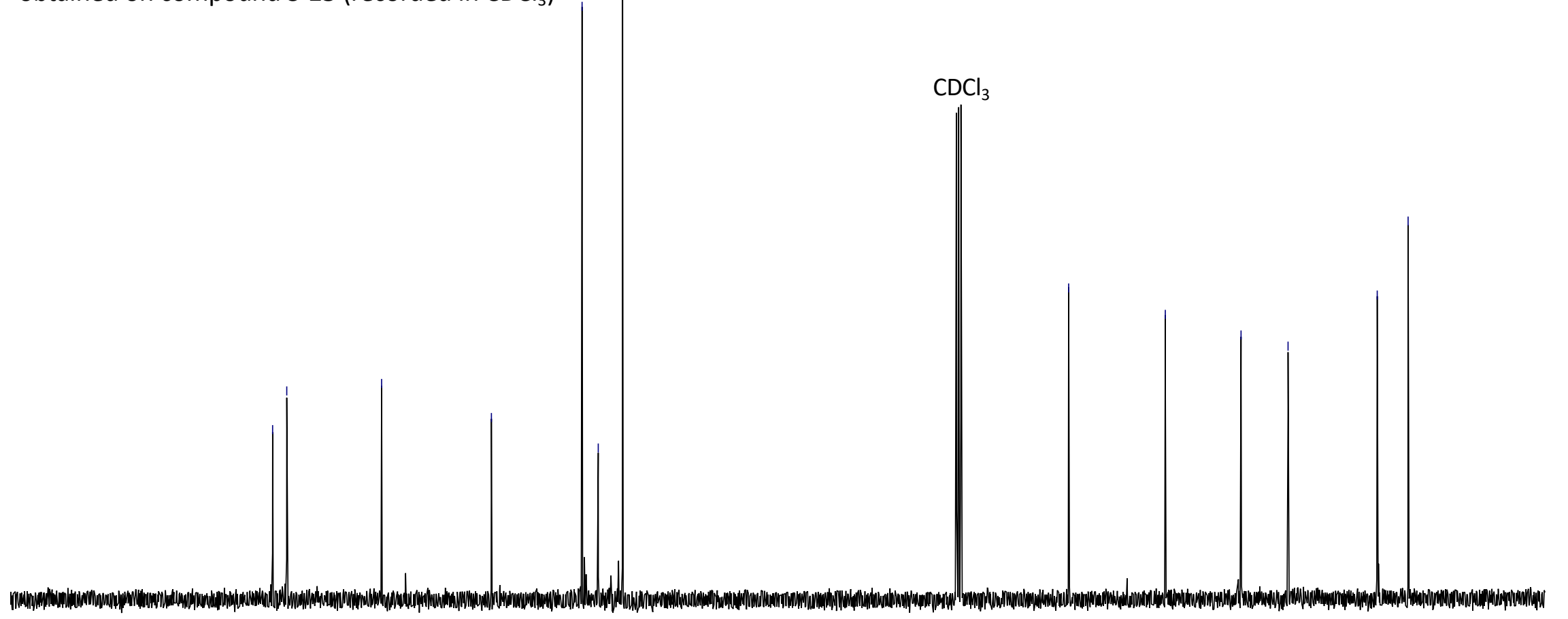

$10 \quad 200 \quad 190 \quad 180$

$150 \quad 140$

130

120

$10 \quad \begin{gathered}100 \\ \text { f1 }\end{gathered}$

90

80 $\begin{array}{ll}1 & 1 \\ 70 & 60\end{array}$ 


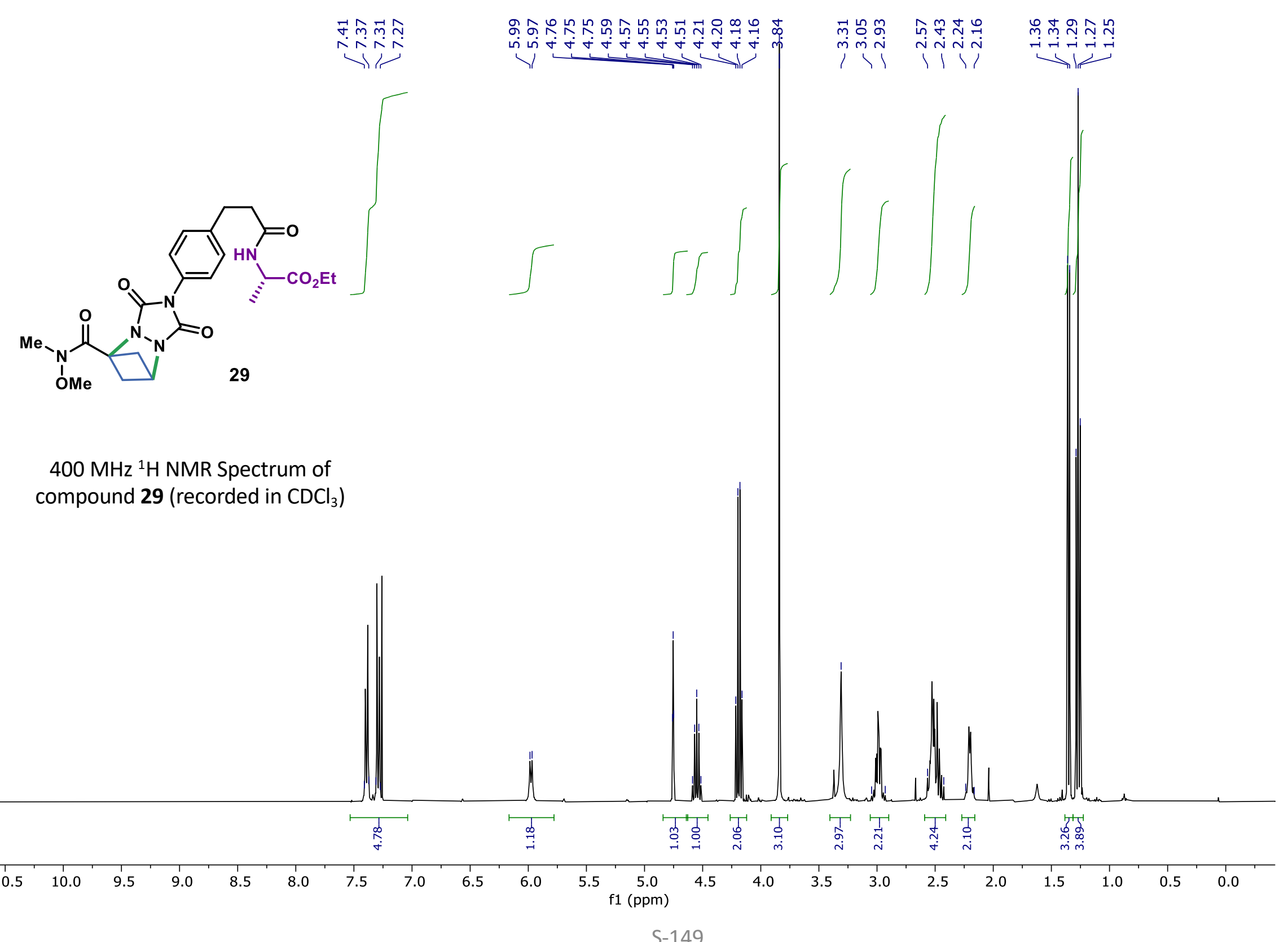

S-149 


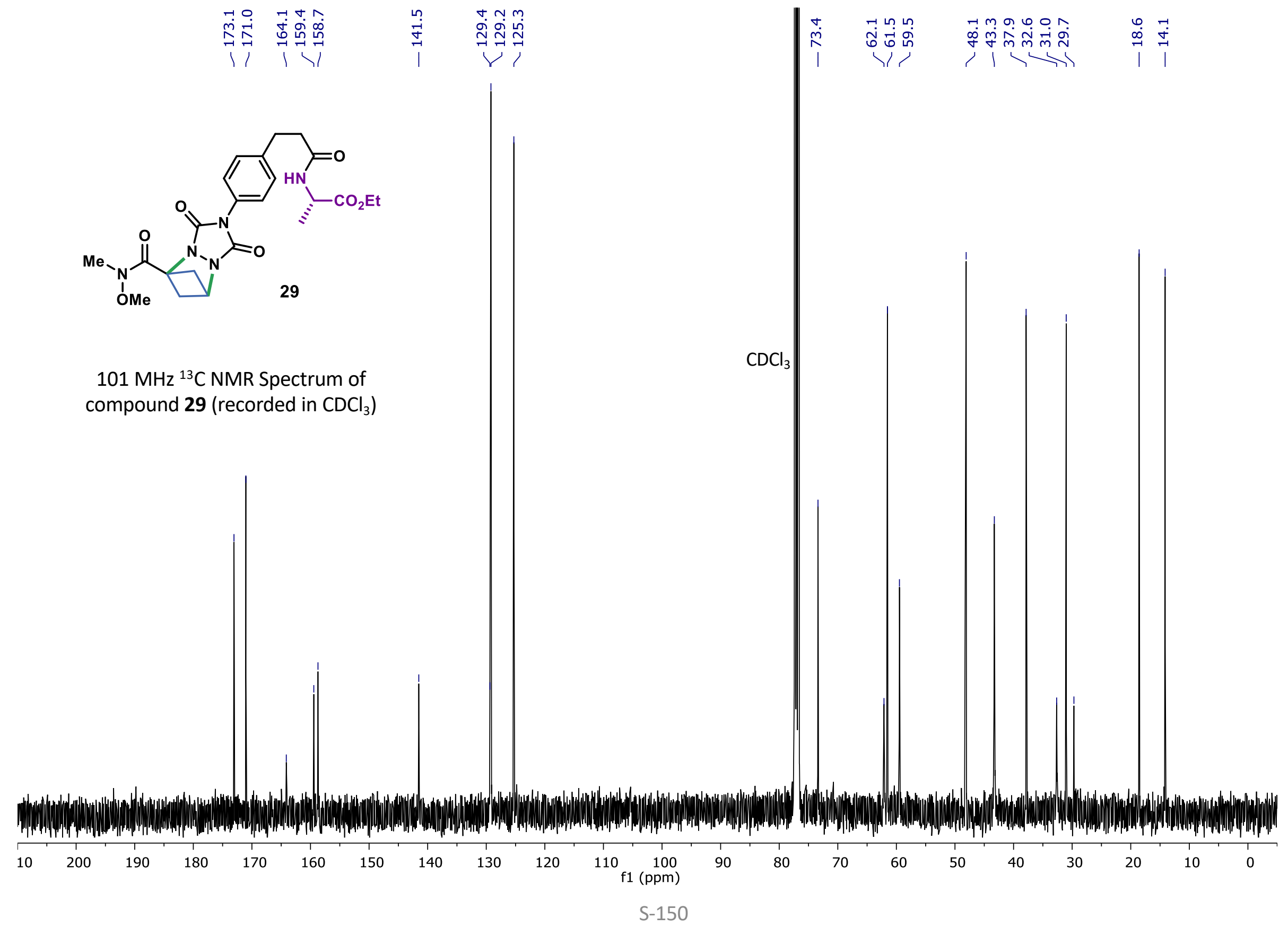




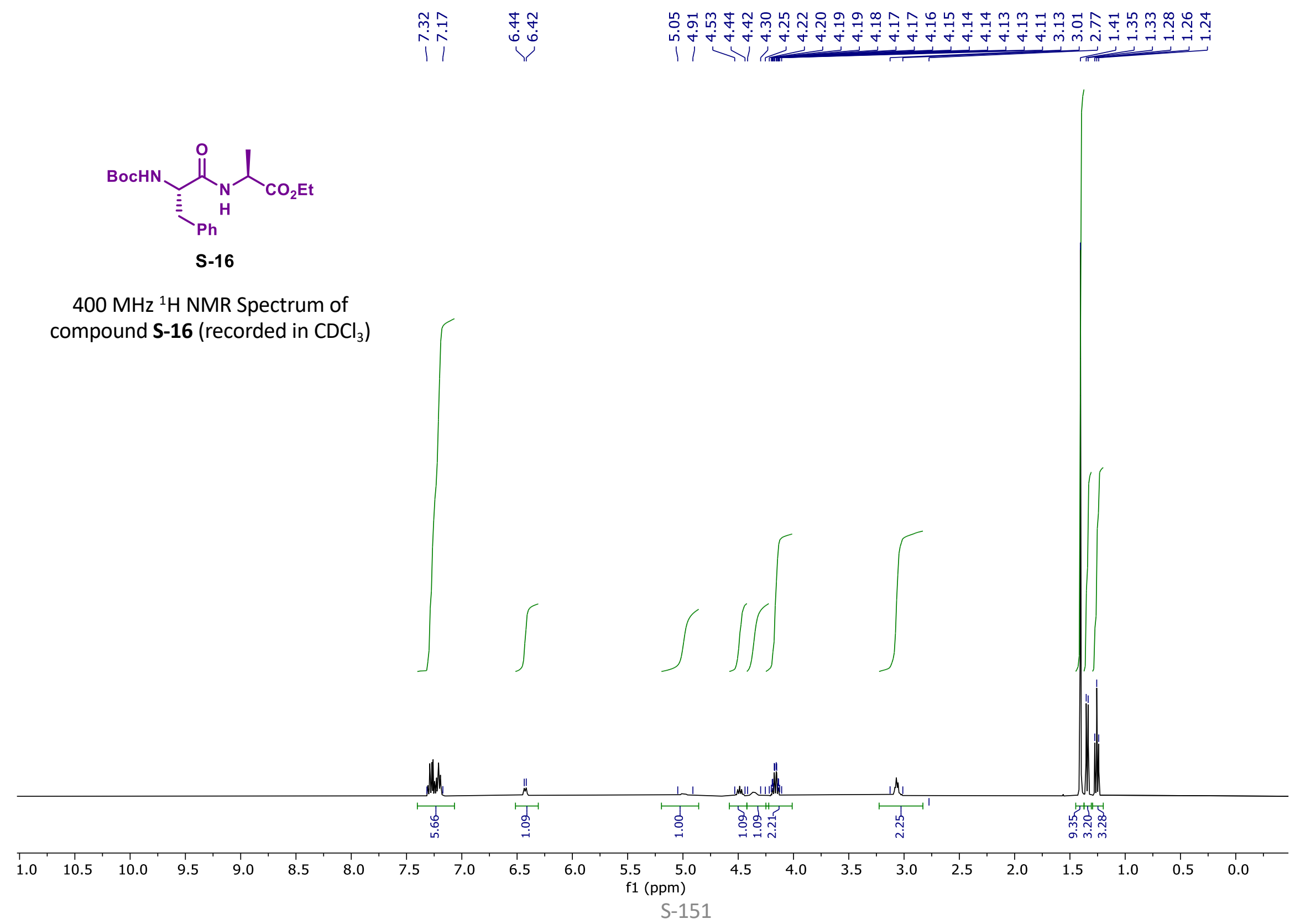




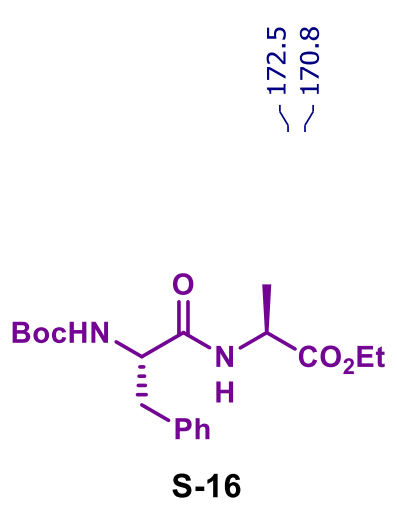

$101 \mathrm{MHz}{ }^{13} \mathrm{C}$ NMR Spectrum of compound S-16 (recorded in $\mathrm{CDCl}_{3}$ )

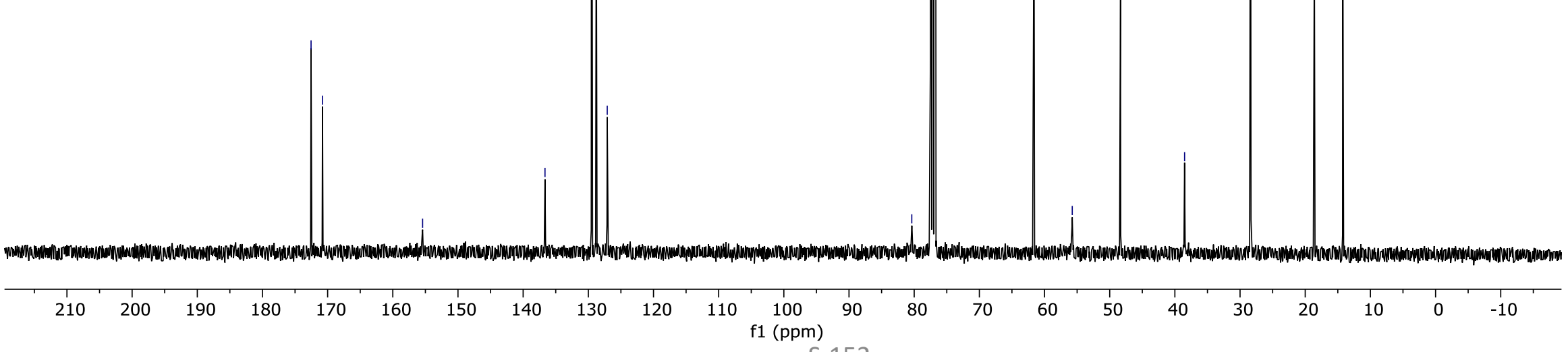




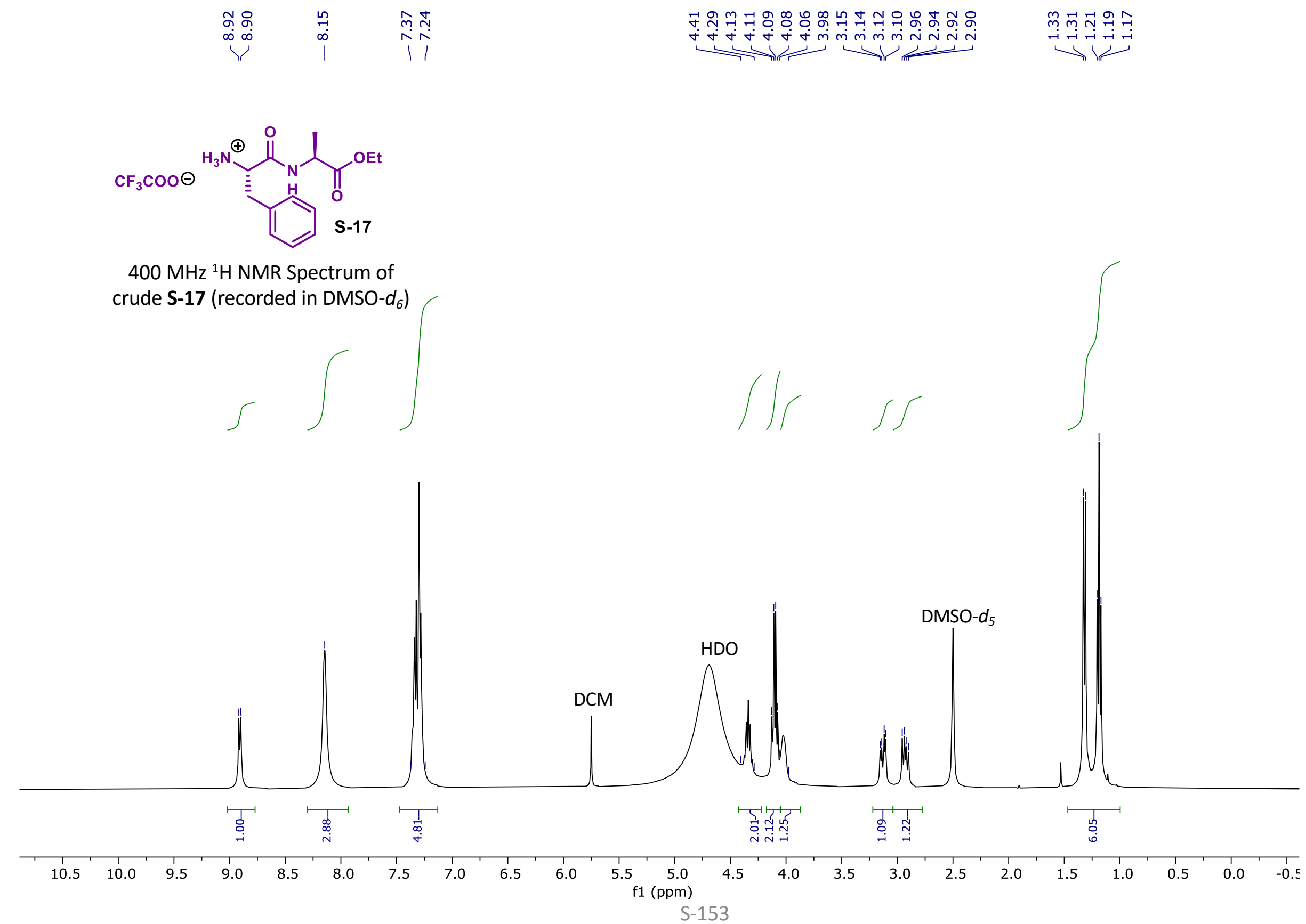




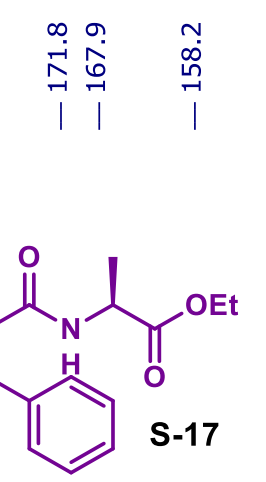

$101 \mathrm{MHz}{ }^{13} \mathrm{C}$ NMR Spectrum of crude

S-17 (recorded in DMSO- $d_{6}$ )
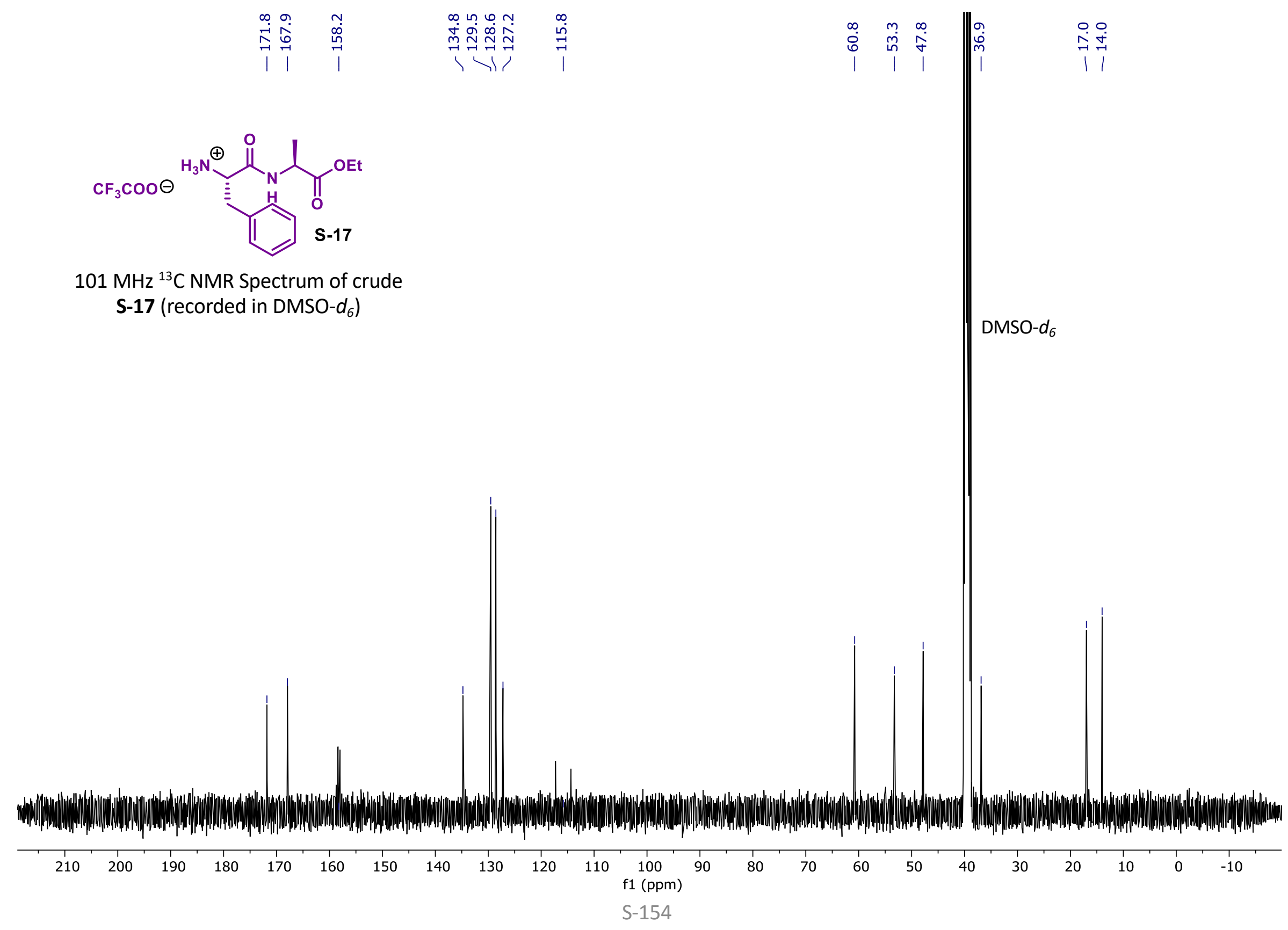


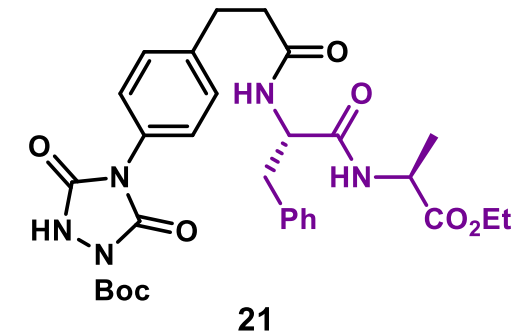

$400 \mathrm{MHz}{ }^{1} \mathrm{H}$ NMR Spectrum of compound 21 (recorded in $\mathrm{CDCl}_{3}$ )
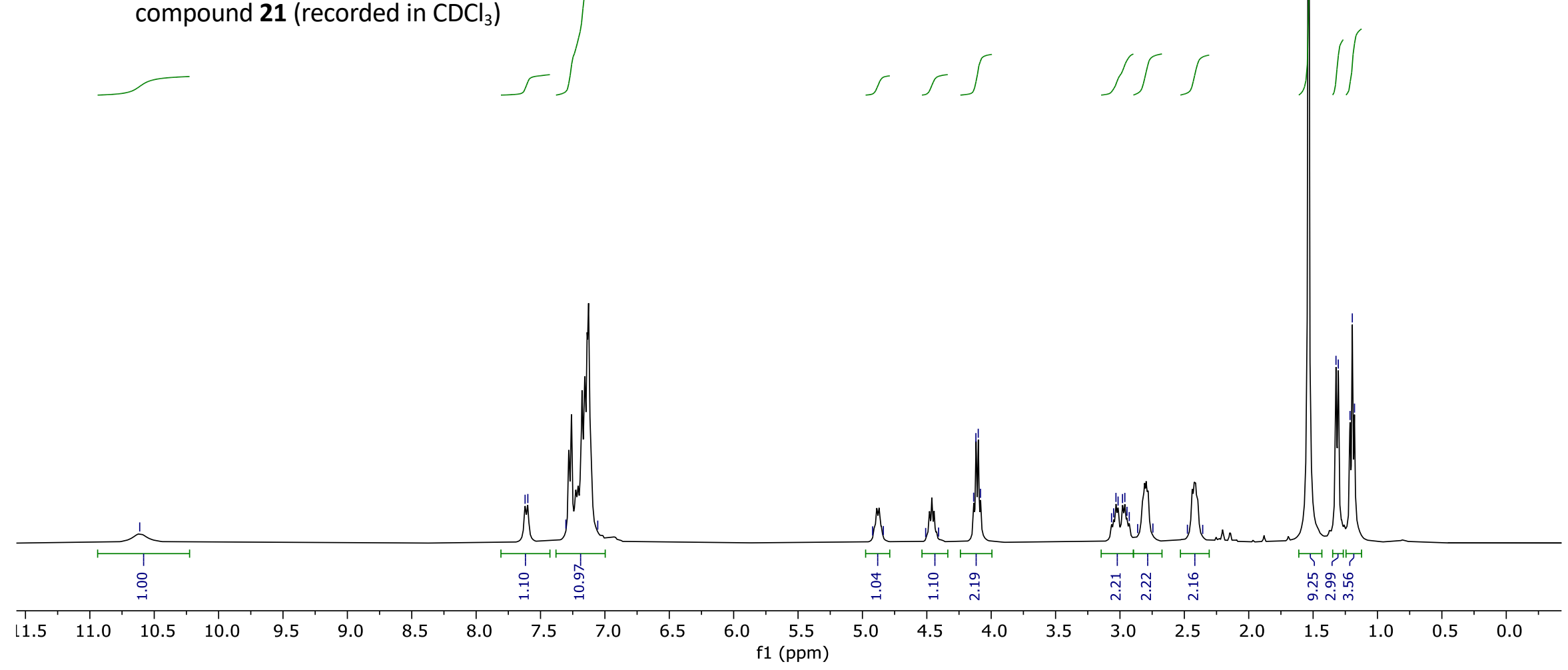


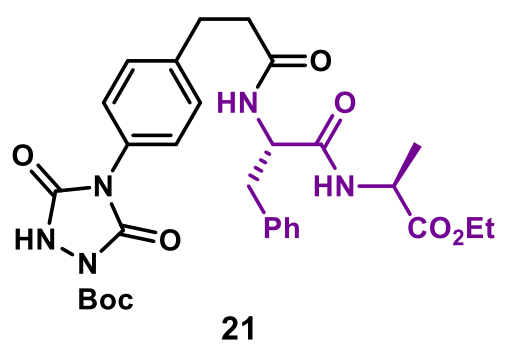

$101 \mathrm{MHz}{ }^{13} \mathrm{C}$ NMR Spectrum of compound $\mathbf{2 1}$ (recorded in $\mathrm{CDCl}_{3}$ )

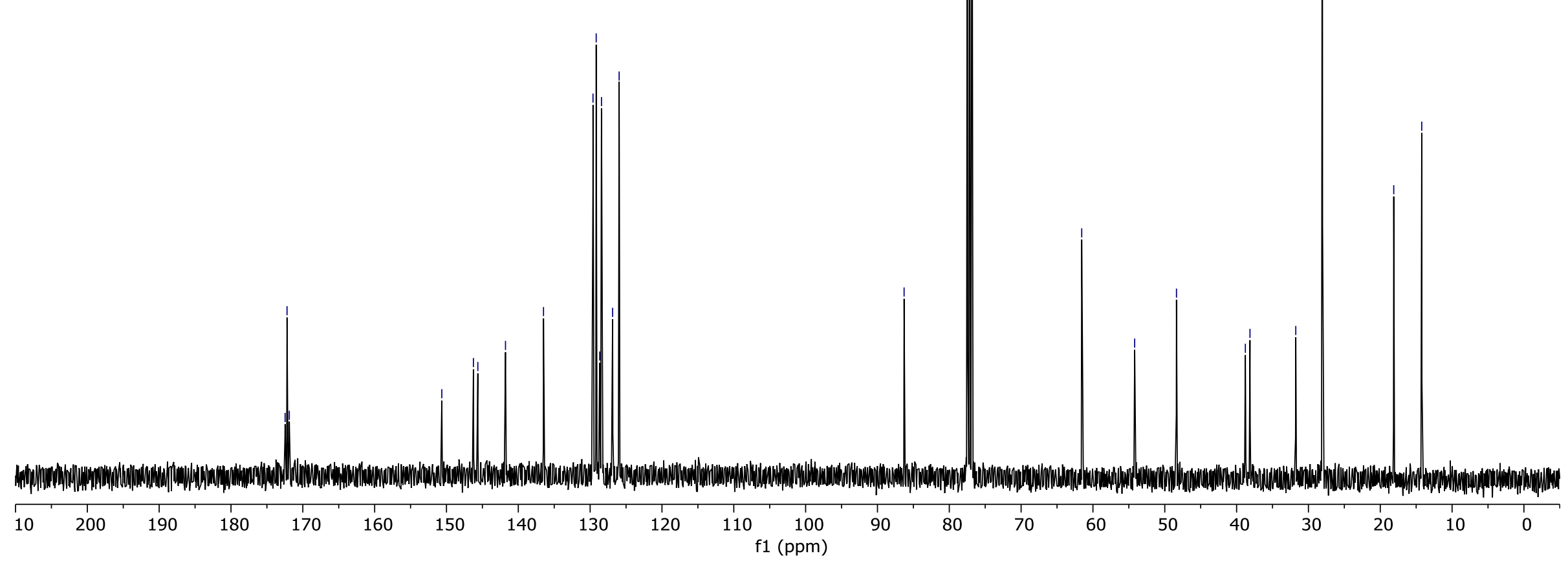




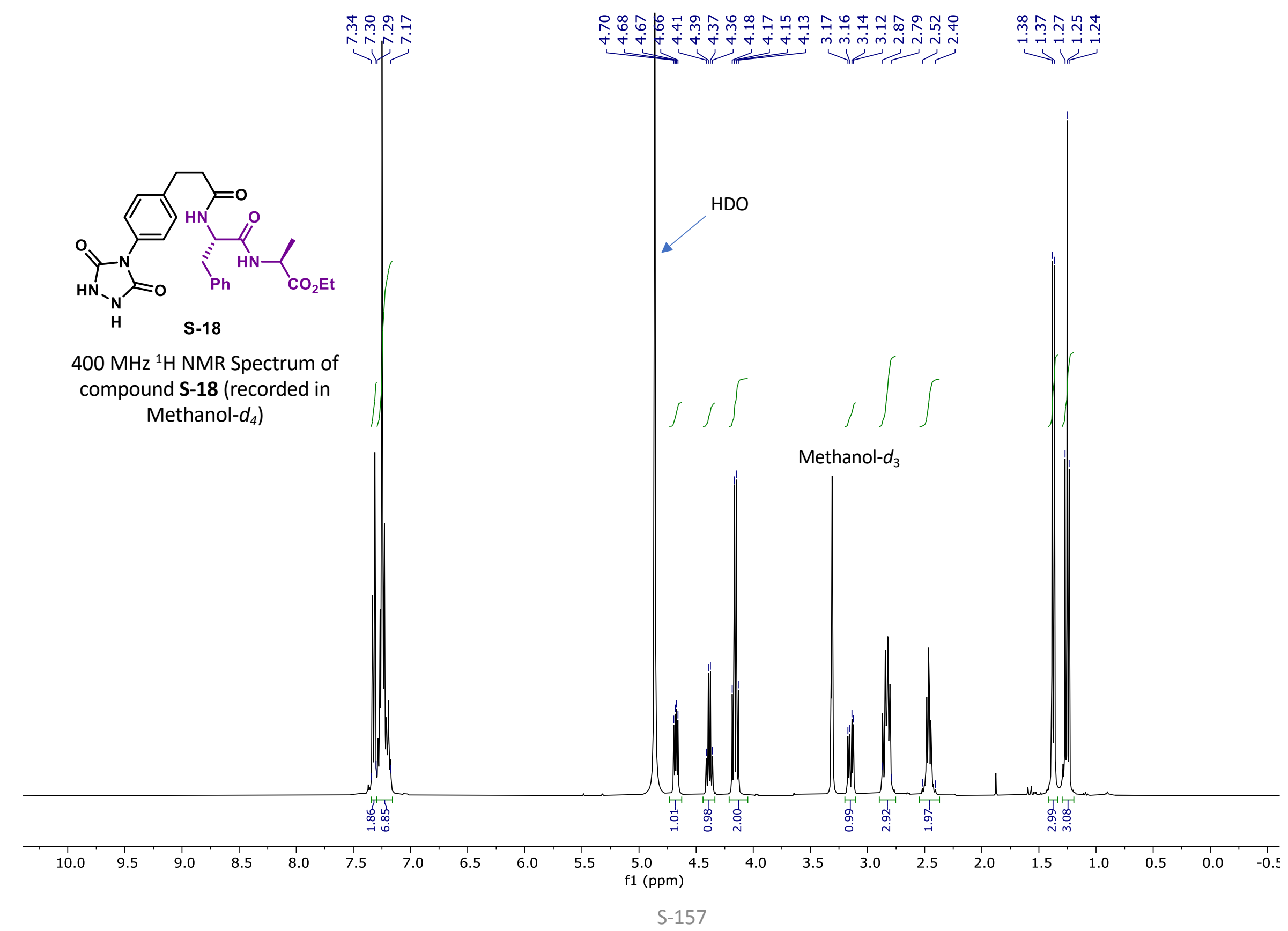




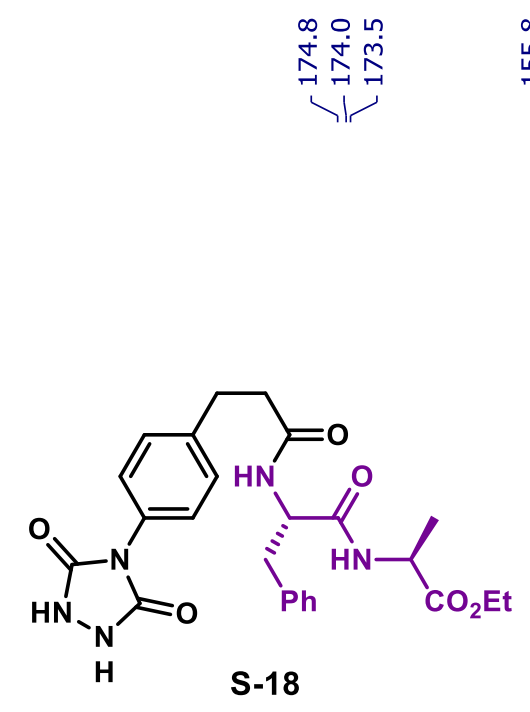

$101 \mathrm{MHz}{ }^{13} \mathrm{C}$ NMR Spectrum of

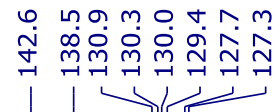

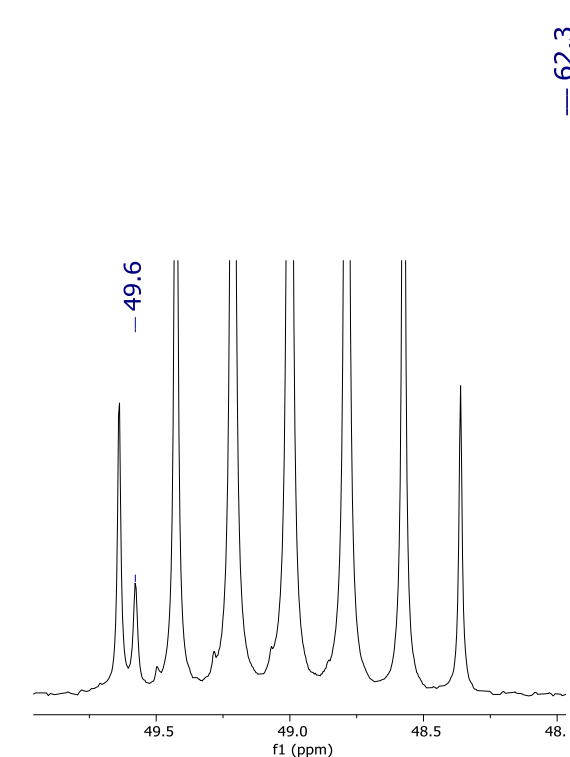

in compound S-18 (recorded in Methanol- $d_{4}$ )

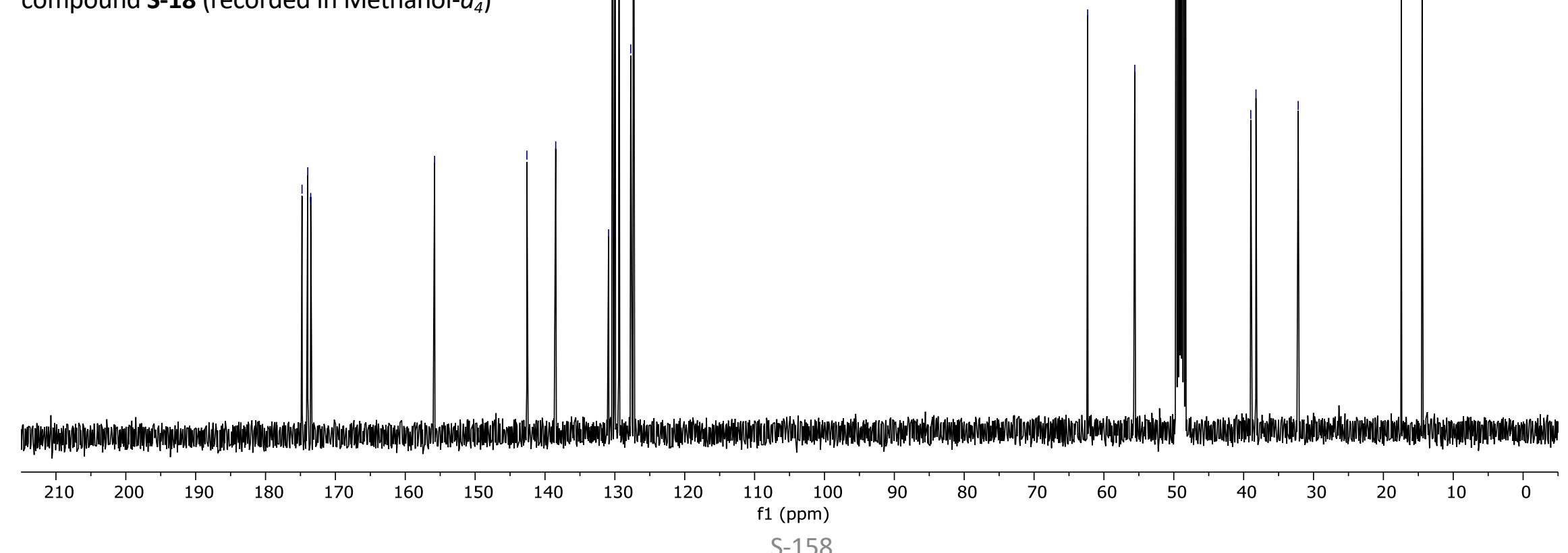




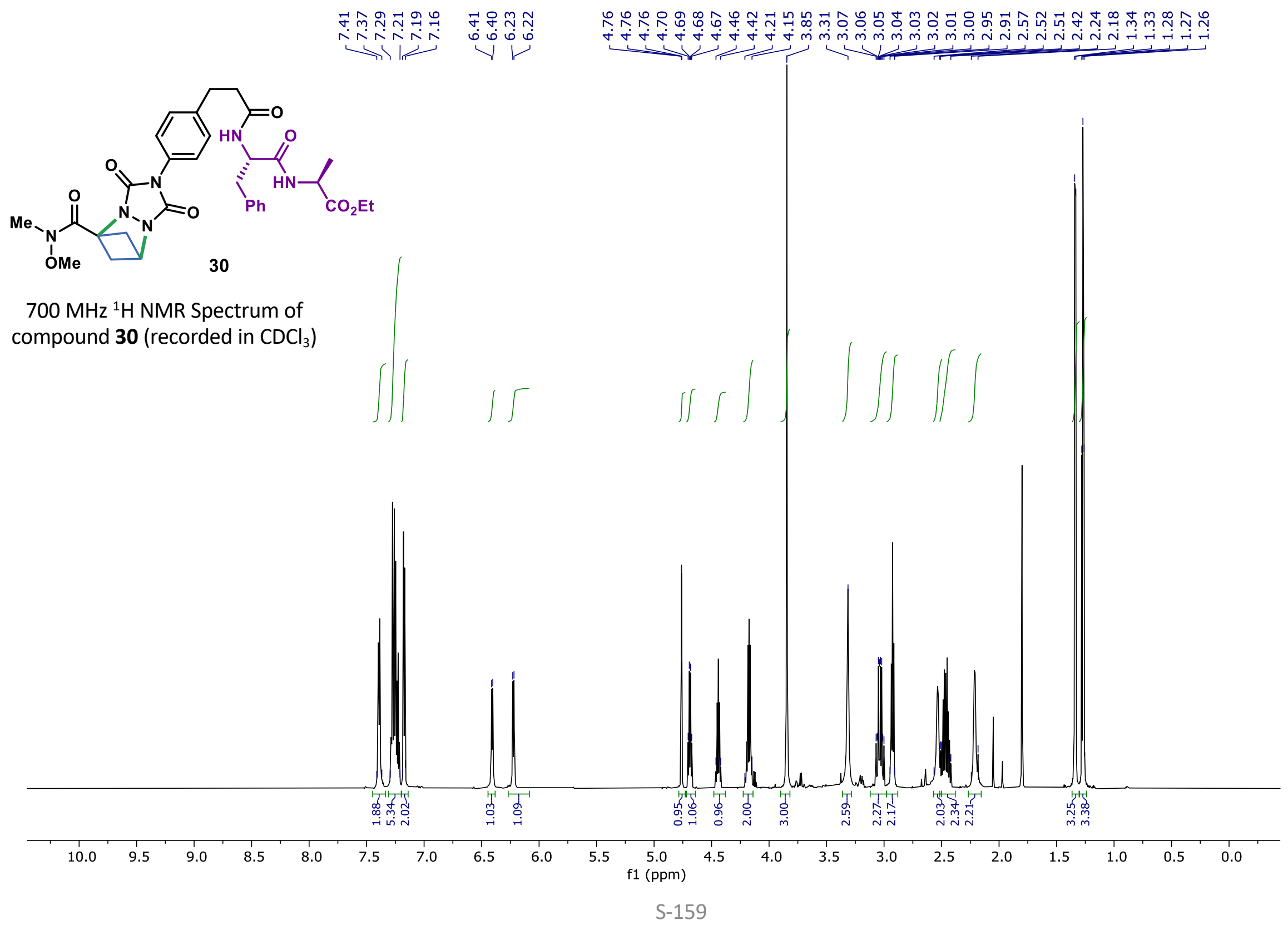




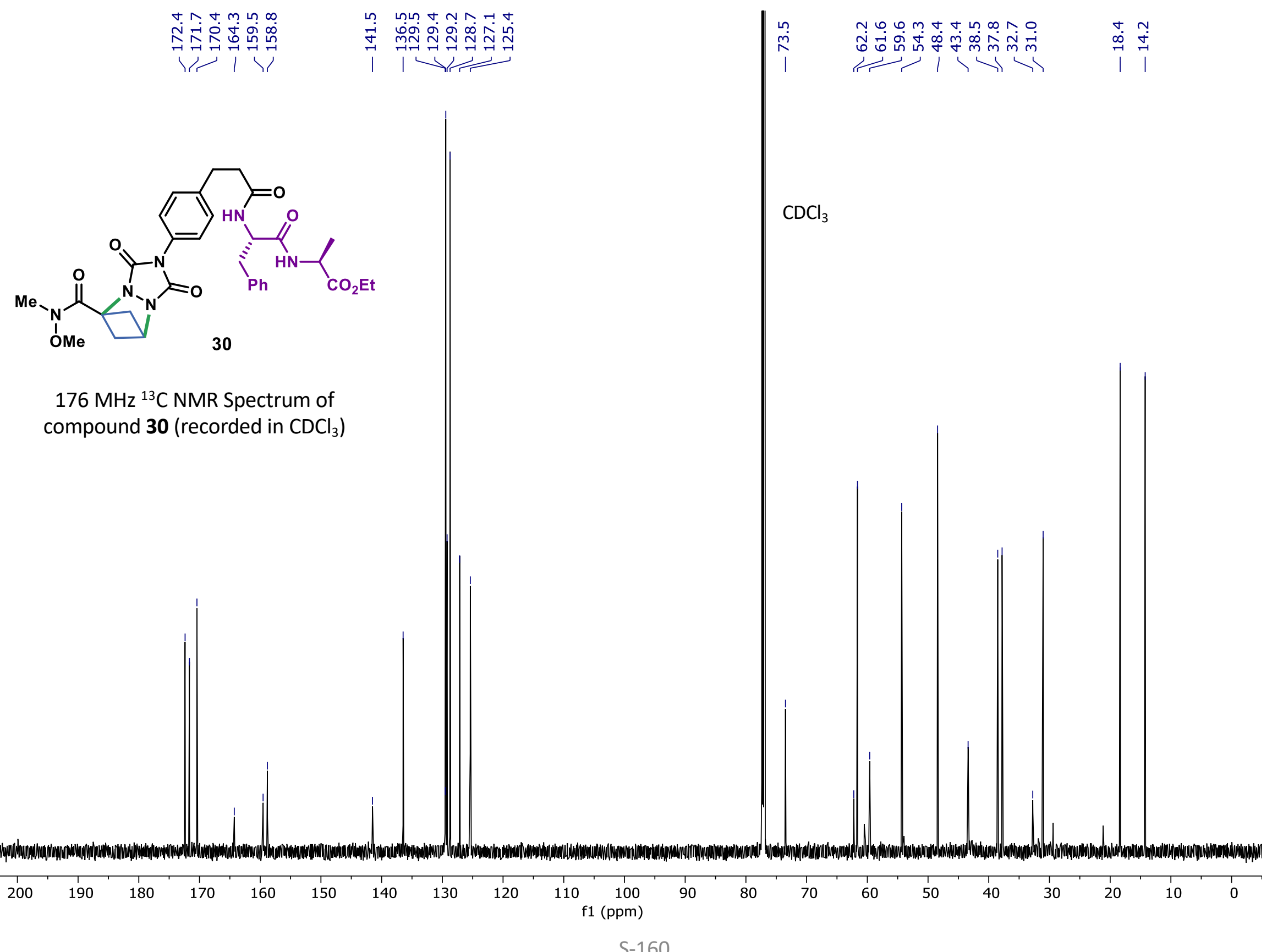




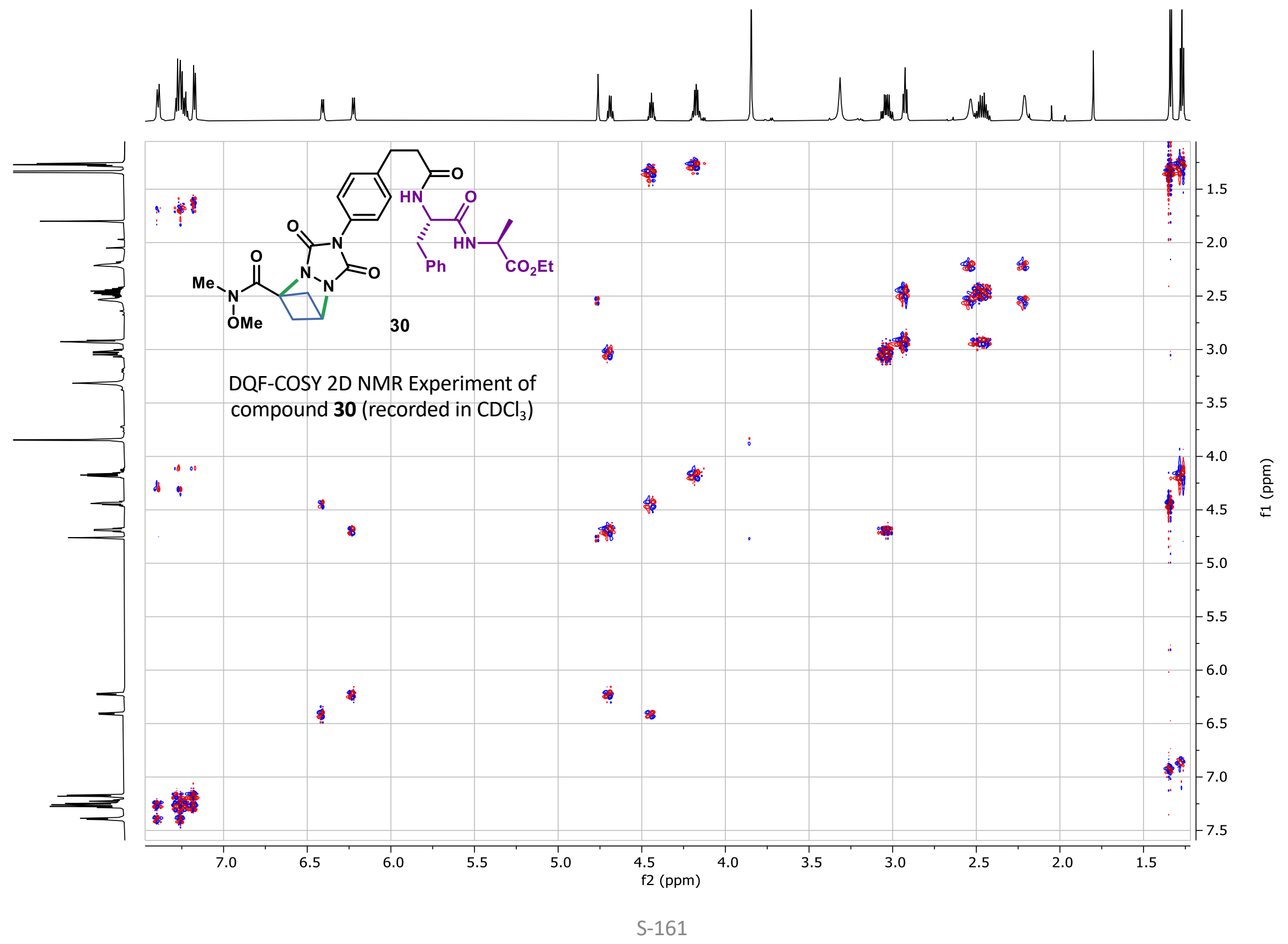




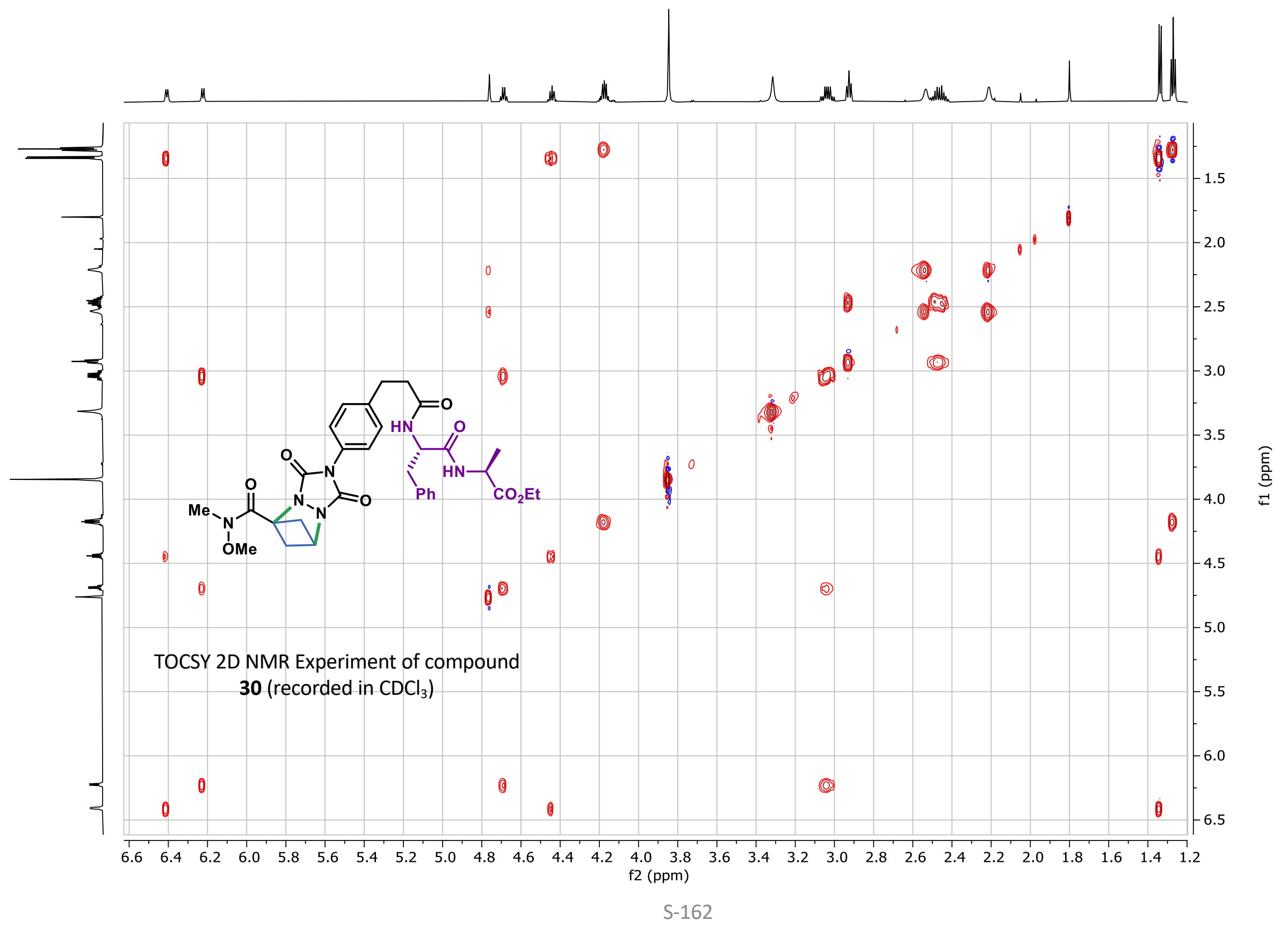




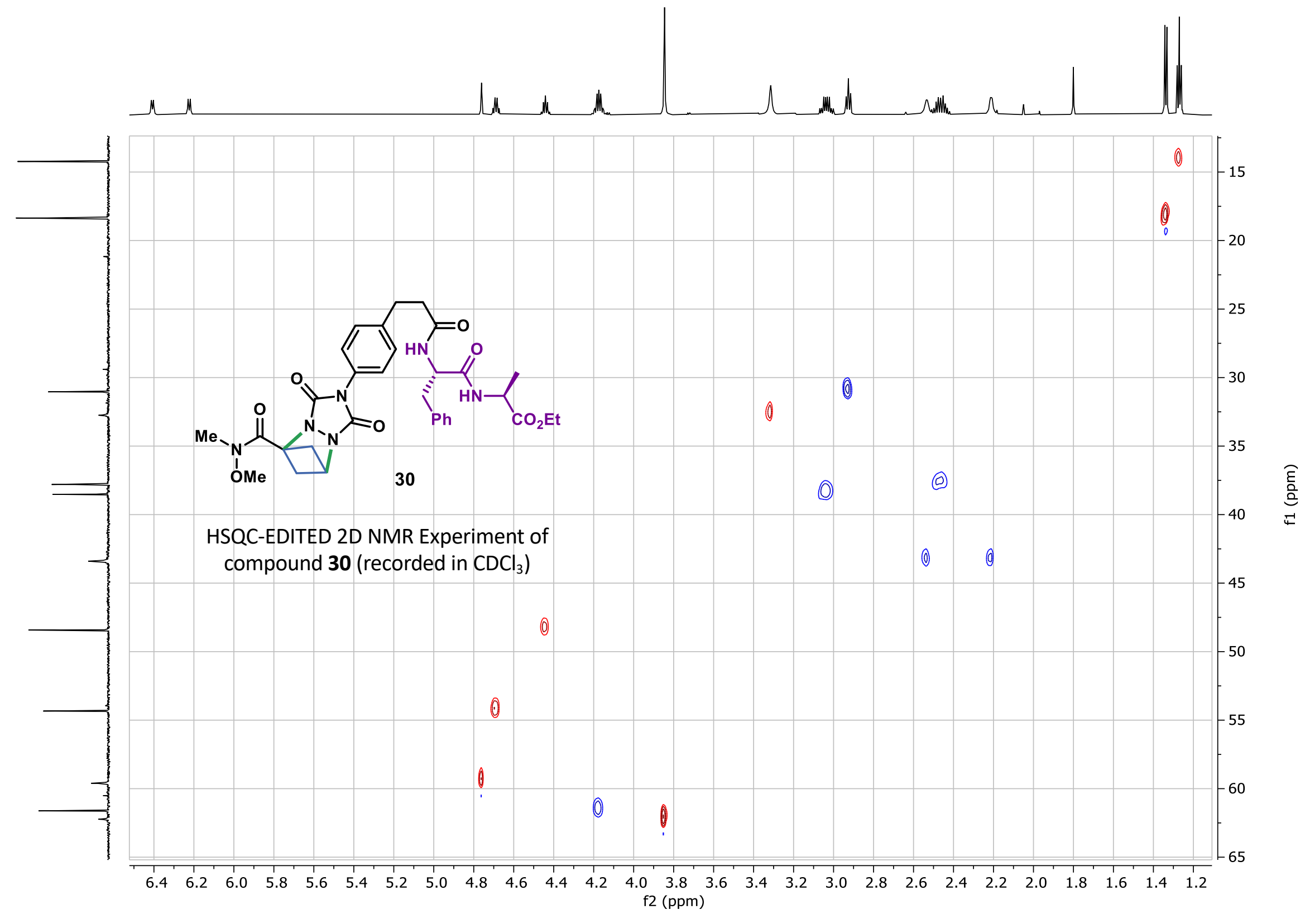




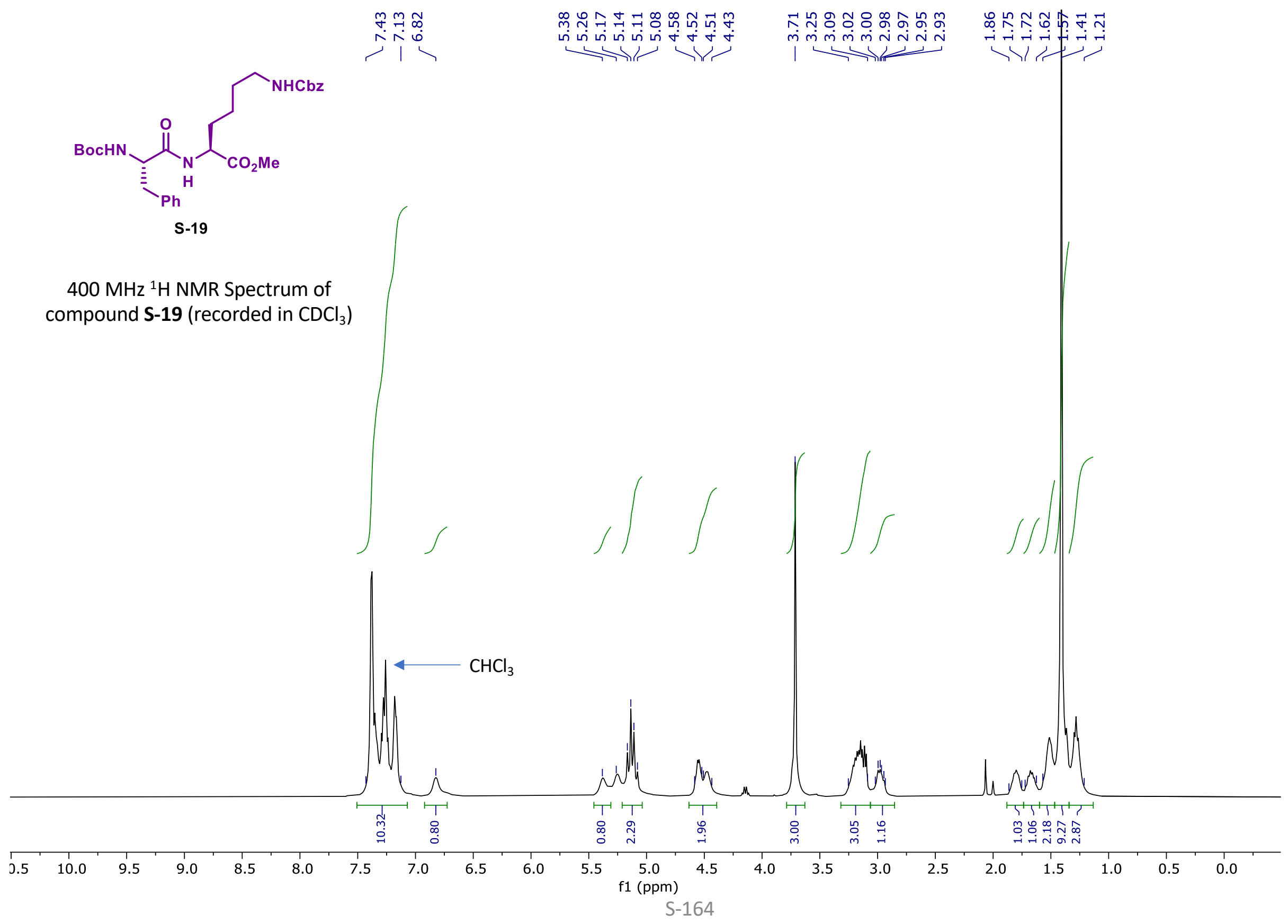




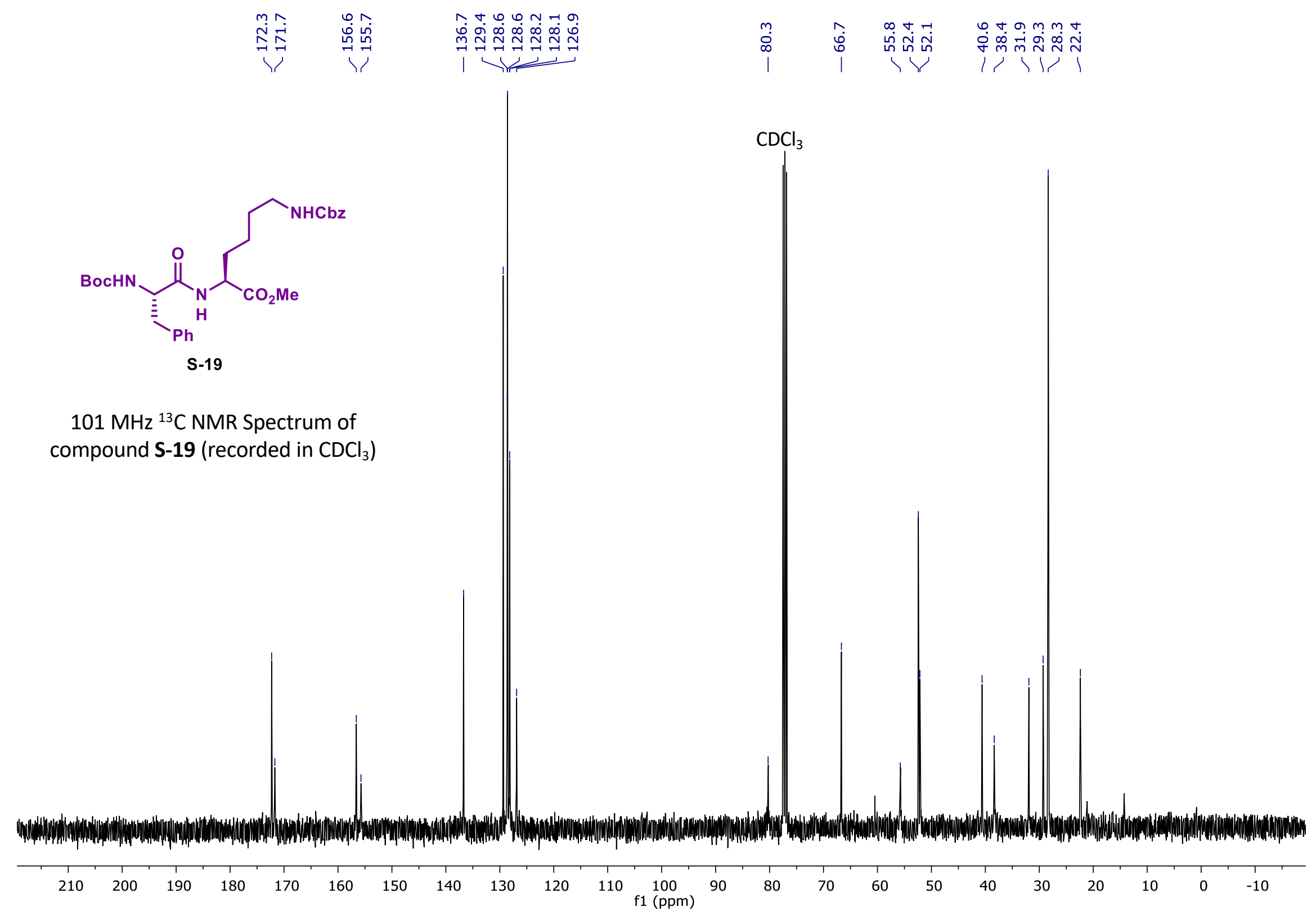




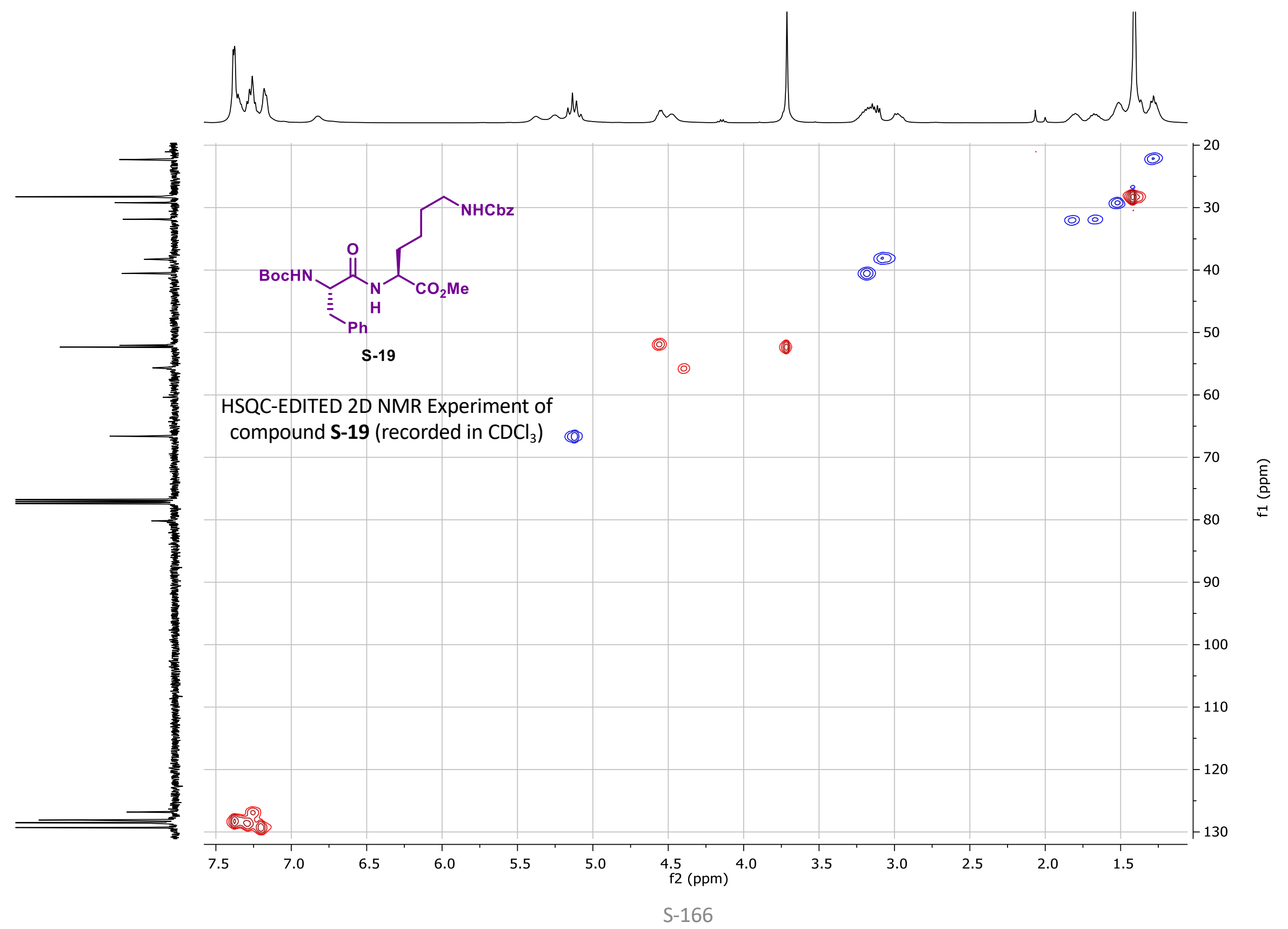




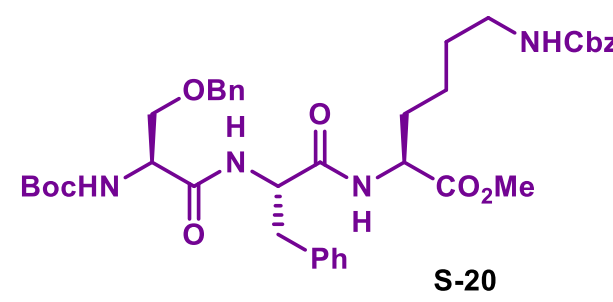

$400 \mathrm{MHz}{ }^{1} \mathrm{H}$ NMR Spectrum of compound $\mathbf{S}-\mathbf{2 0}$ (recorded in $\mathrm{CDCl}_{3}$ )

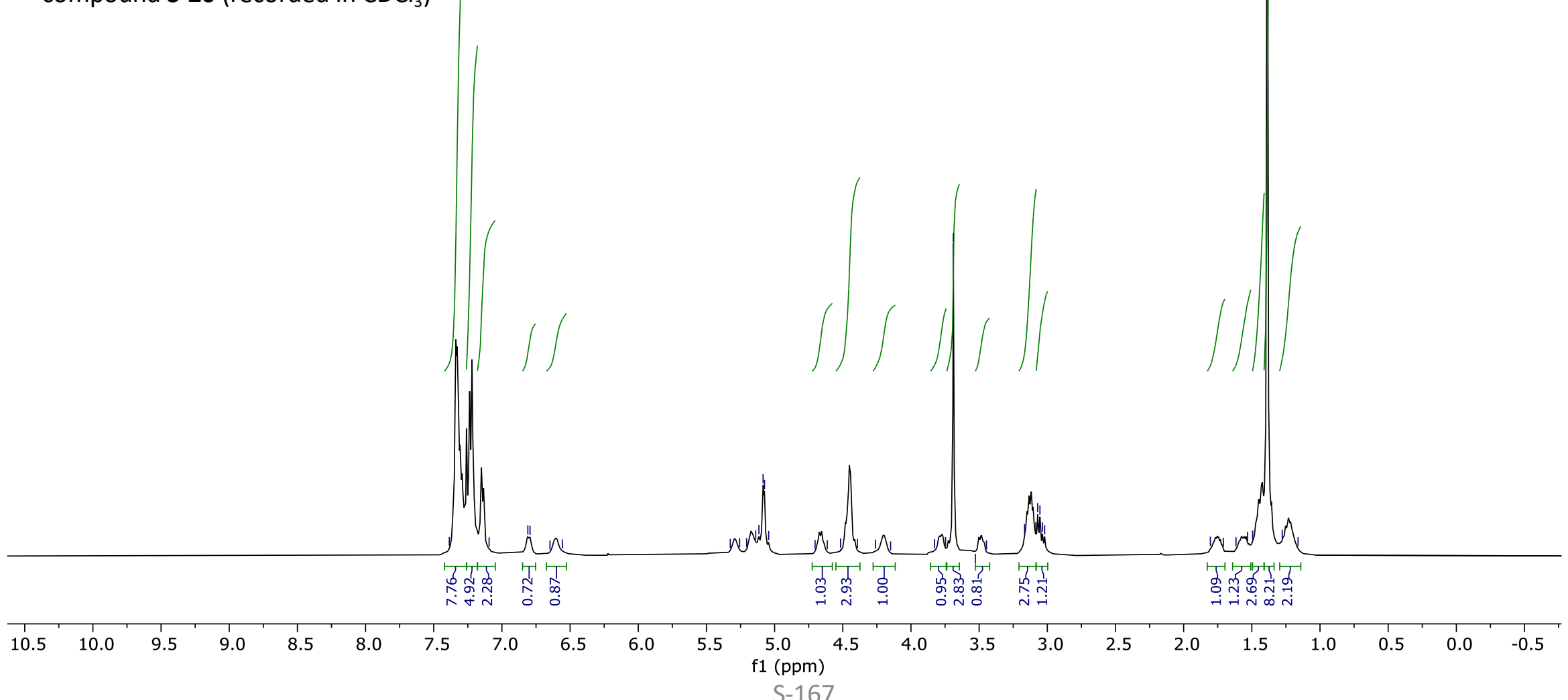




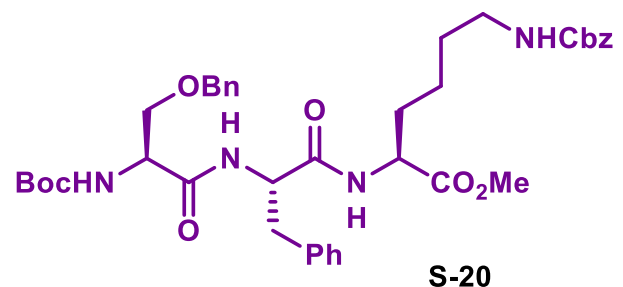

$101 \mathrm{MHz}{ }^{13} \mathrm{C}$ NMR Spectrum of compound S-20 (recorded in $\mathrm{CDCl}_{3}$ )

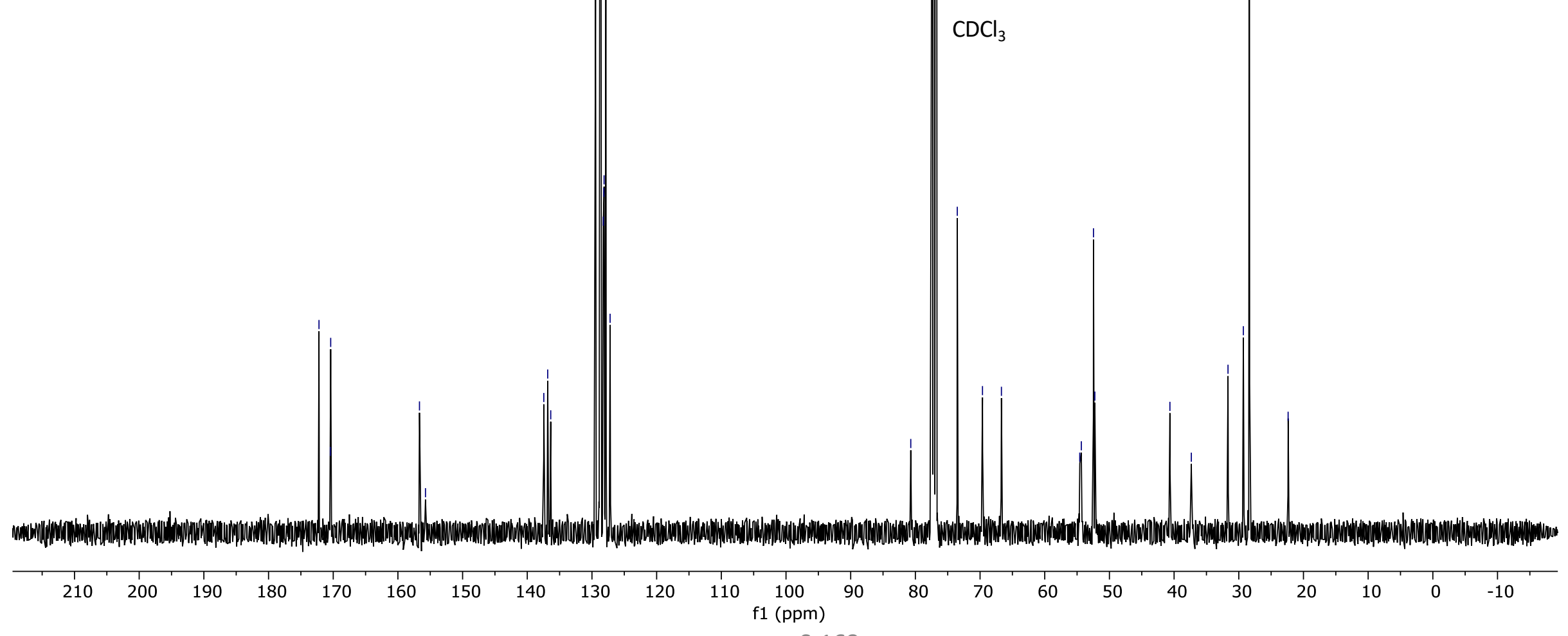




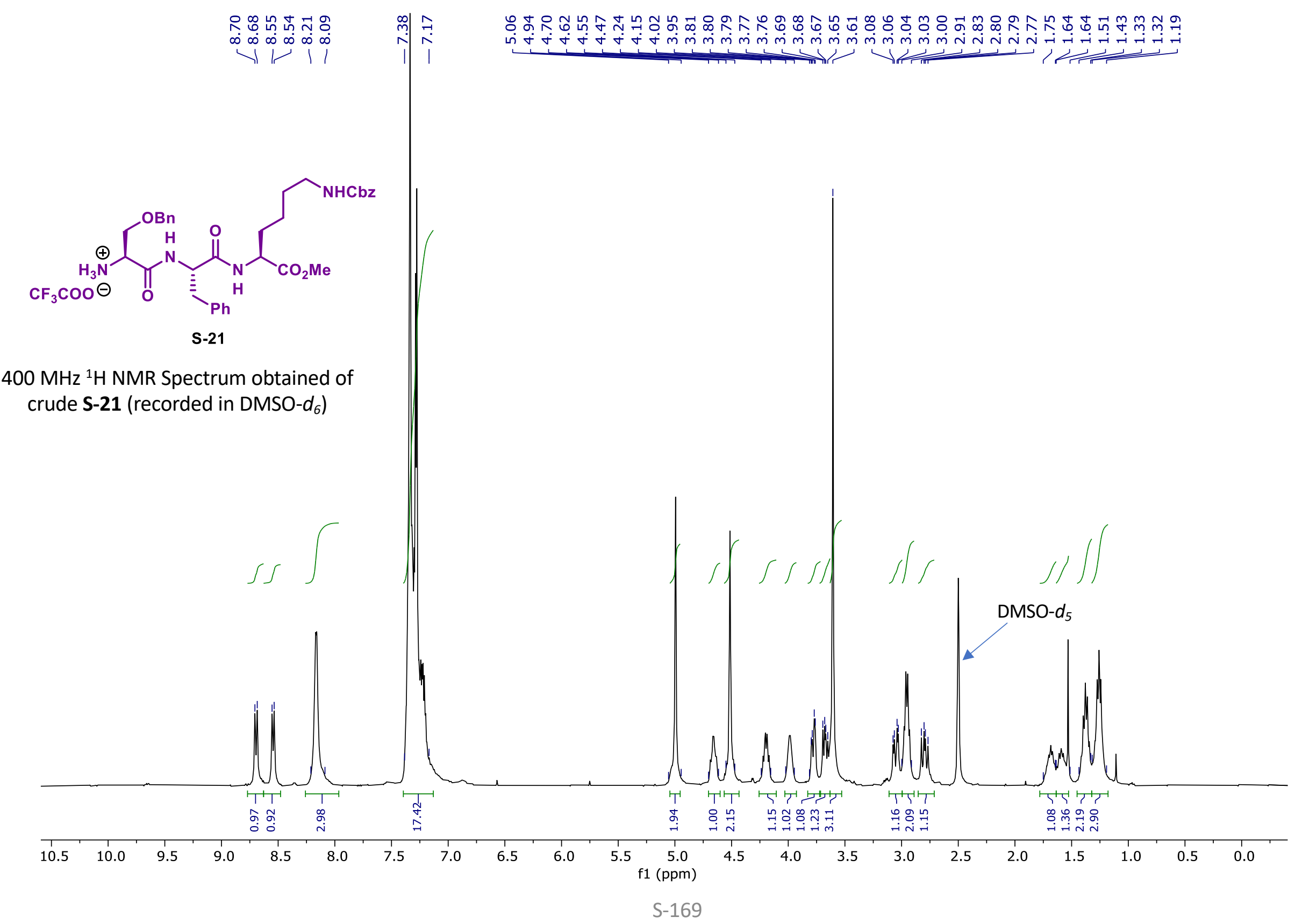




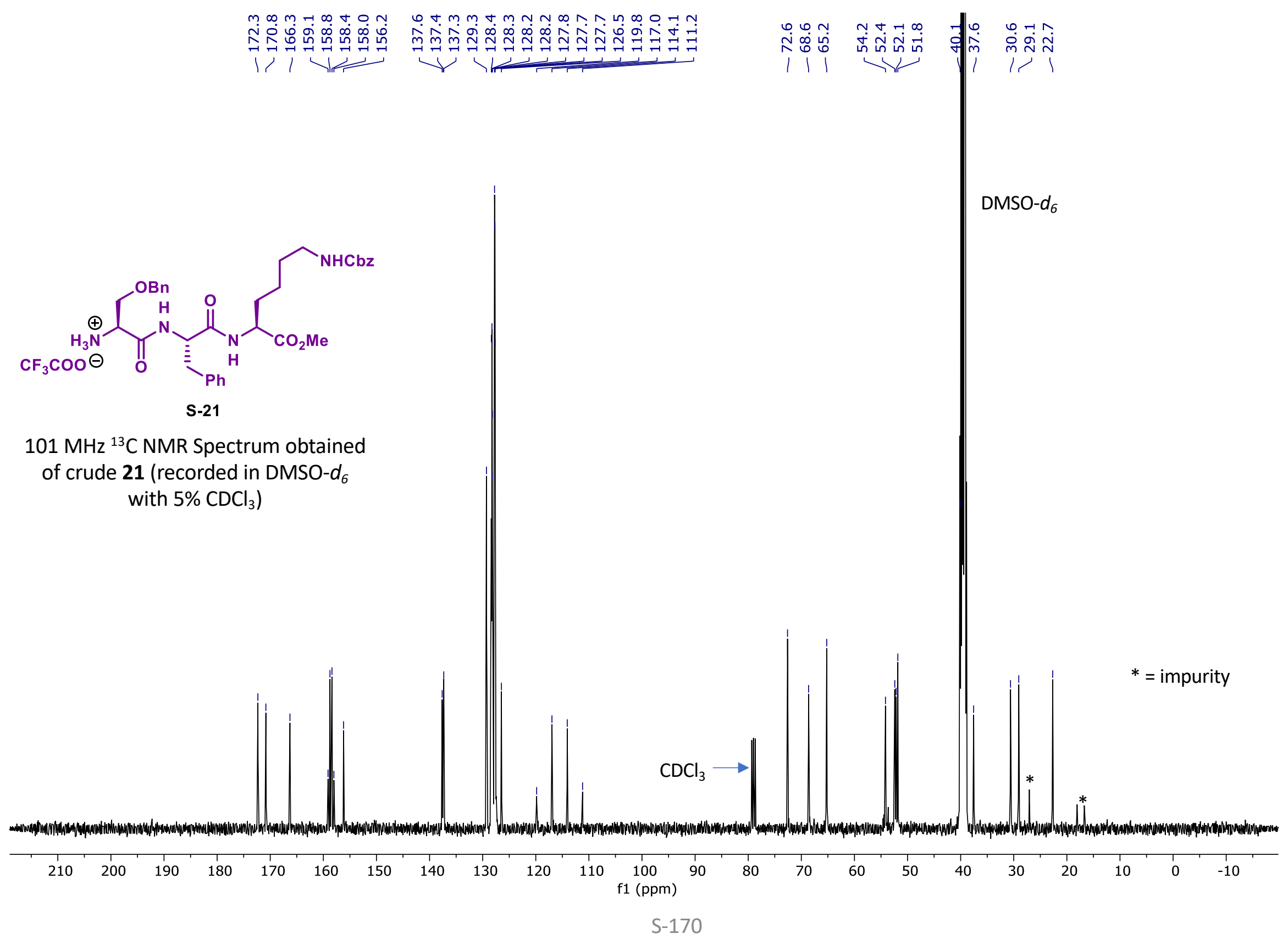




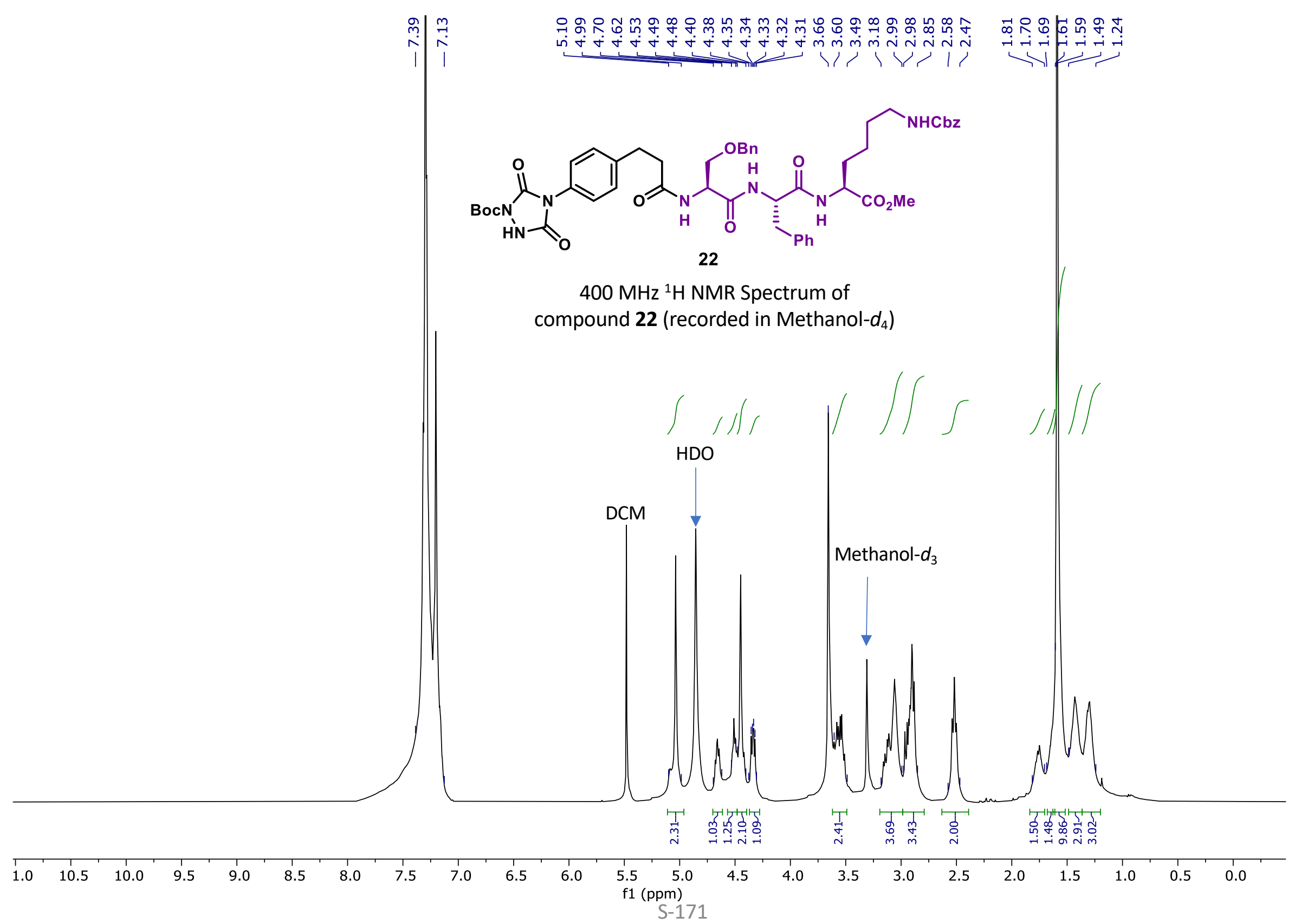




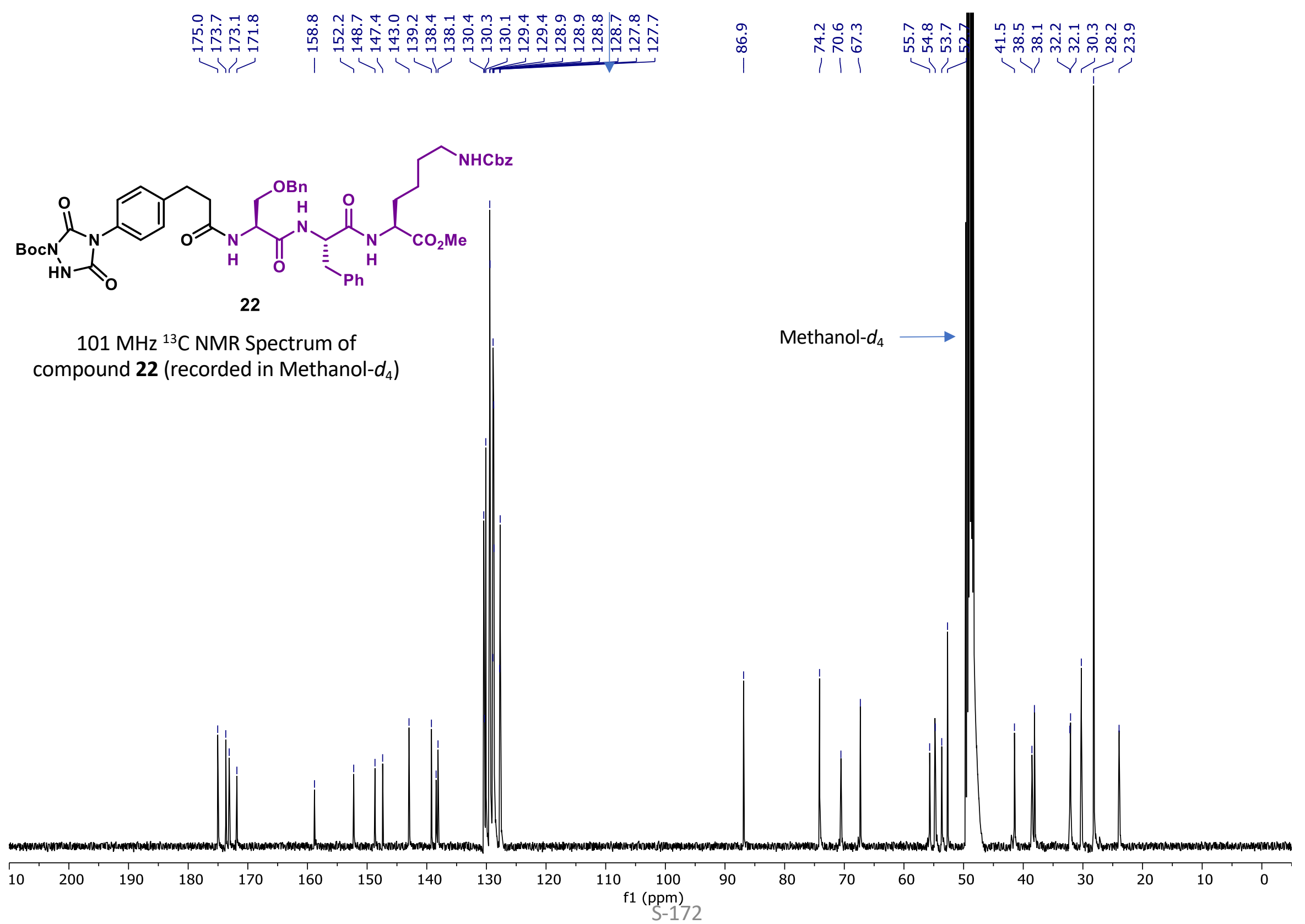




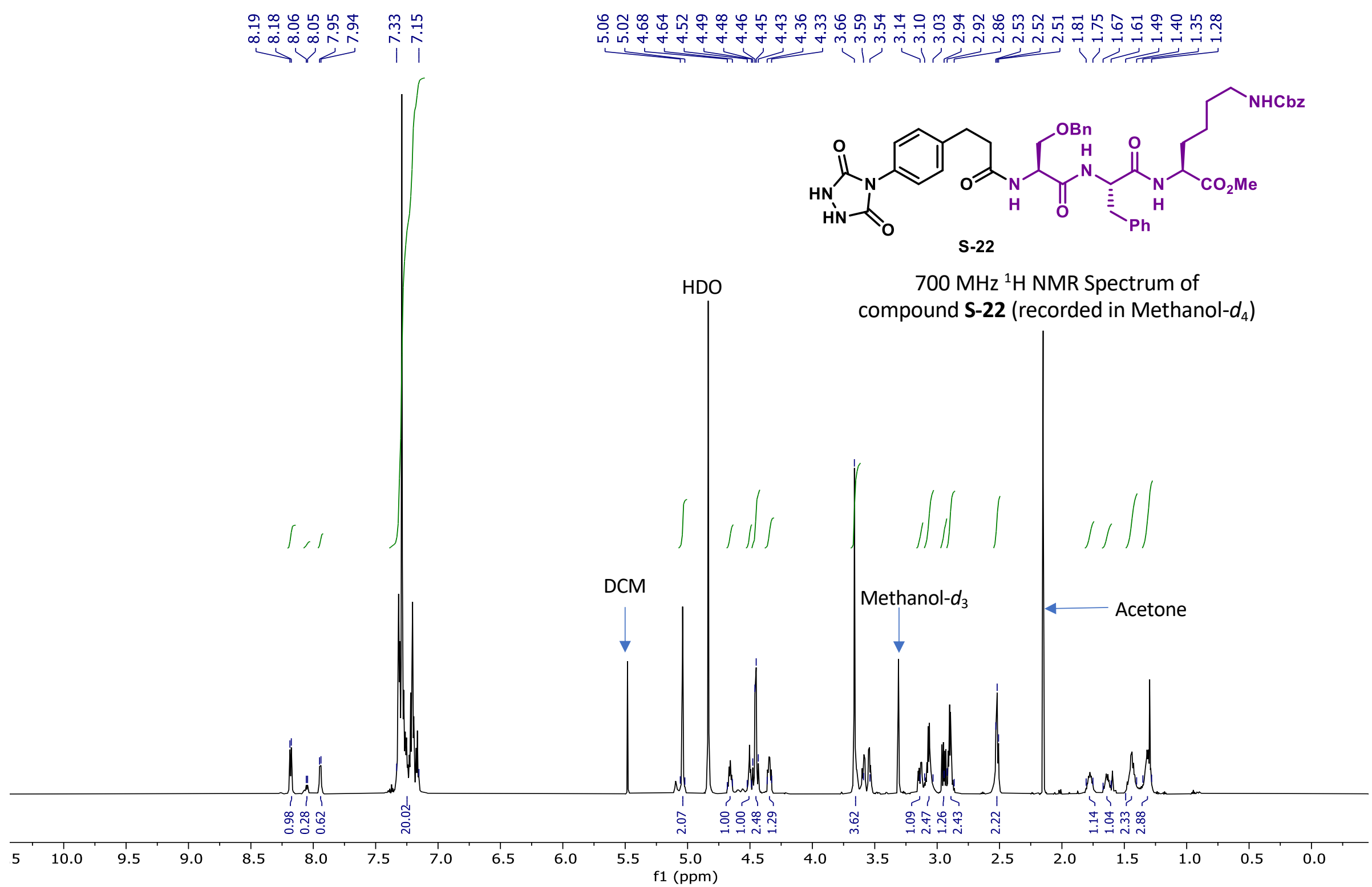


<smiles>CC(=O)NCCCCC(NC(=O)[C@H](Cc1ccccc1)NC(=O)C(COc1ccccc1)NC(=O)CCc1ccc(-n2c(=O)[nH][nH]c2=O)cc1)C(C)=O</smiles>

$176 \mathrm{MHz}{ }^{13} \mathrm{C}$ NMR Spectrum of compound S-22 (recorded in Methanol- $d_{4}$ )

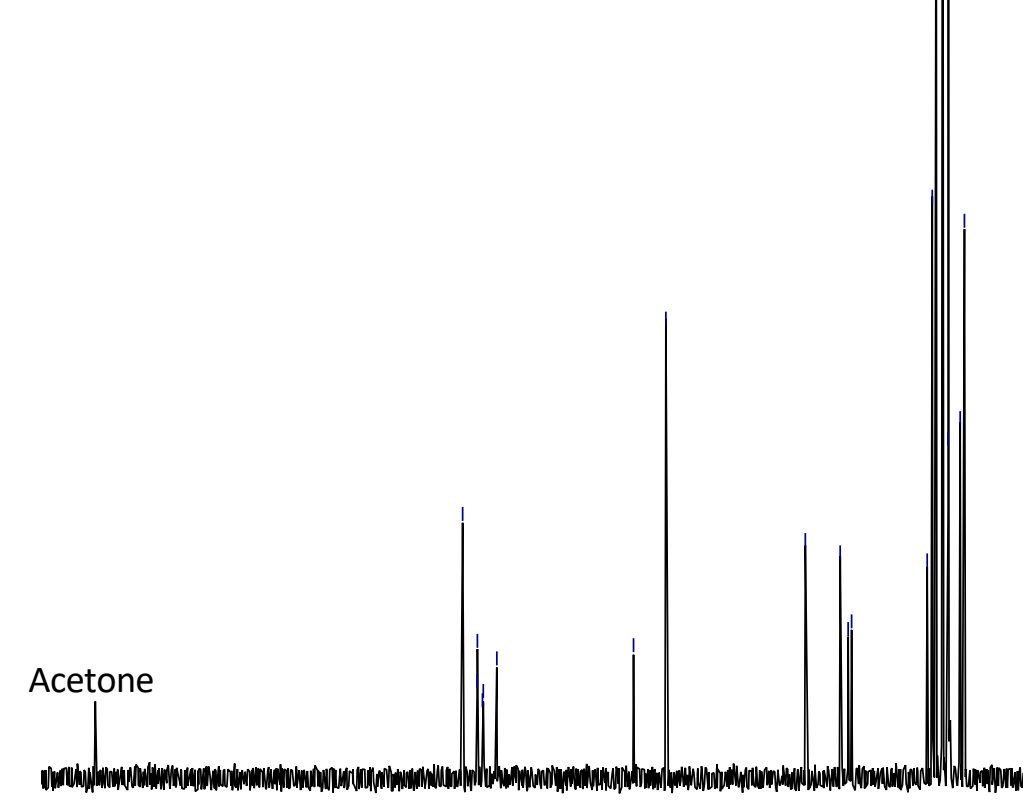

Methanol- $d_{4}$

\section{Acetone}

DCM

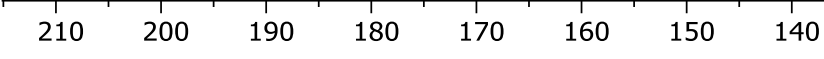

$130 \quad 120$ 


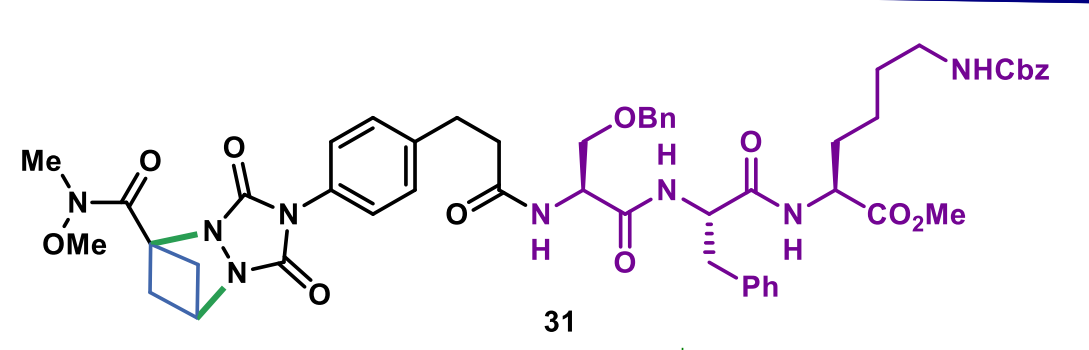

$700 \mathrm{MHz}{ }^{1} \mathrm{H}$ NMR Spectrum of compound $\mathbf{3 1}$ (recorded in Methanol- $\left.d_{4}\right)$

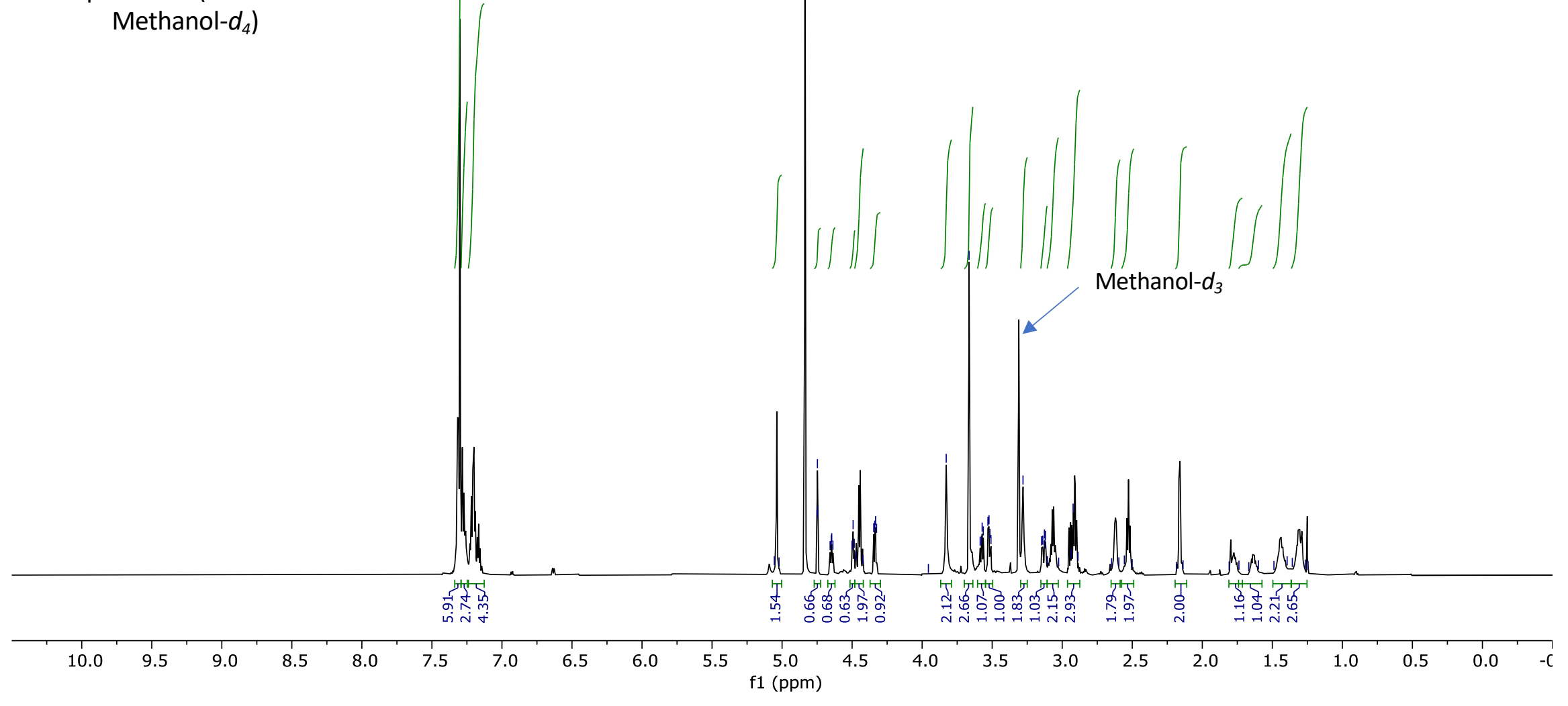




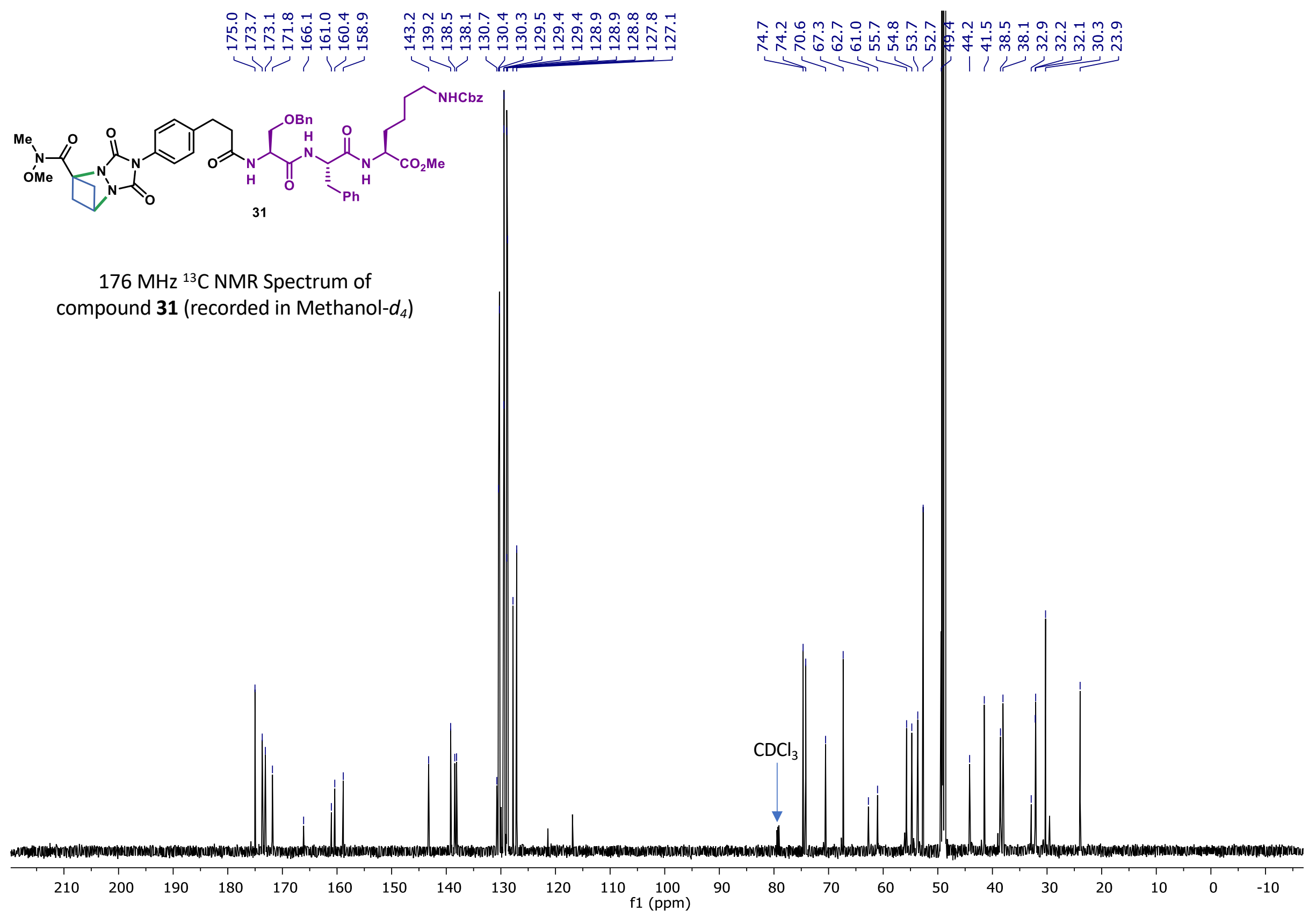




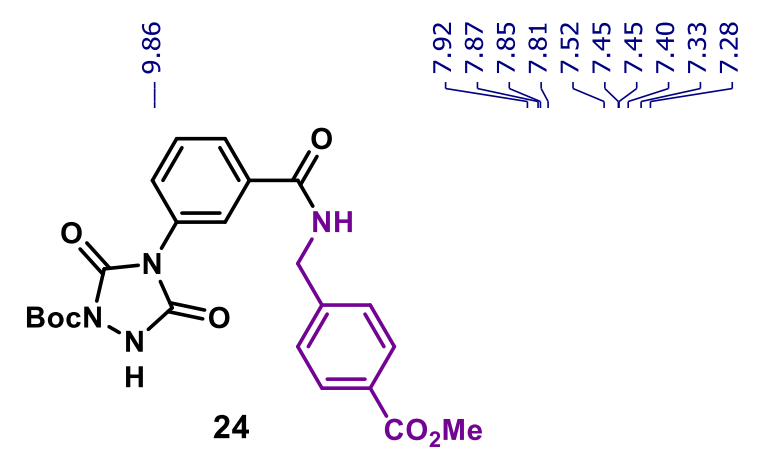

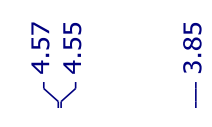

$400 \mathrm{MHz}{ }^{1} \mathrm{H}$ NMR Spectrum of compound $\mathbf{2 4}$ (recorded in $\mathrm{CDCl}_{3}$ )

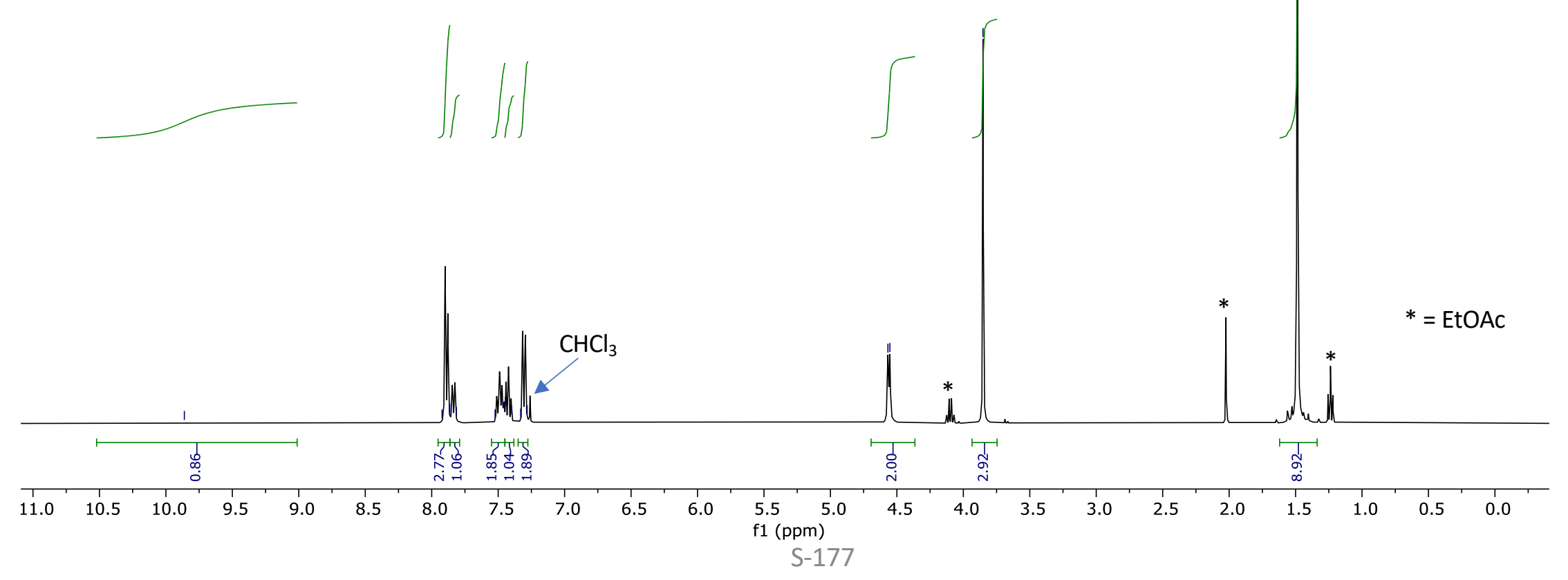




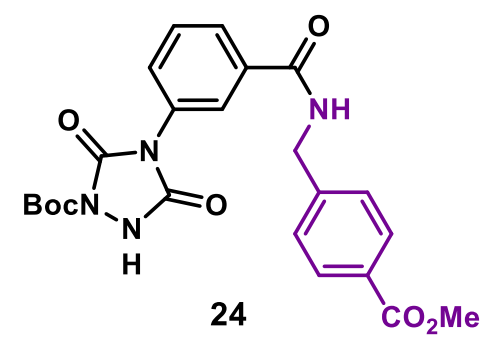

$101 \mathrm{MHz}{ }^{13} \mathrm{C}$ NMR Spectrum of compound $\mathbf{2 4}$ (recorded in $\mathrm{CDCl}_{3}$ )

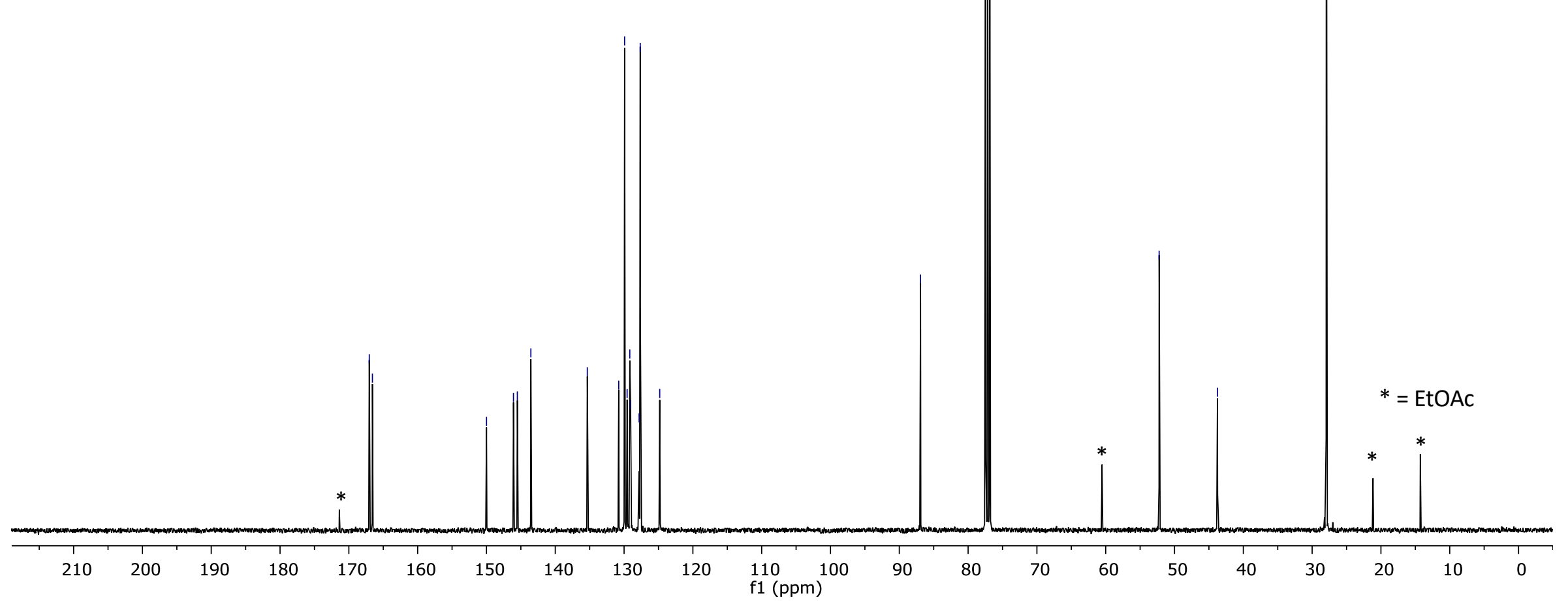




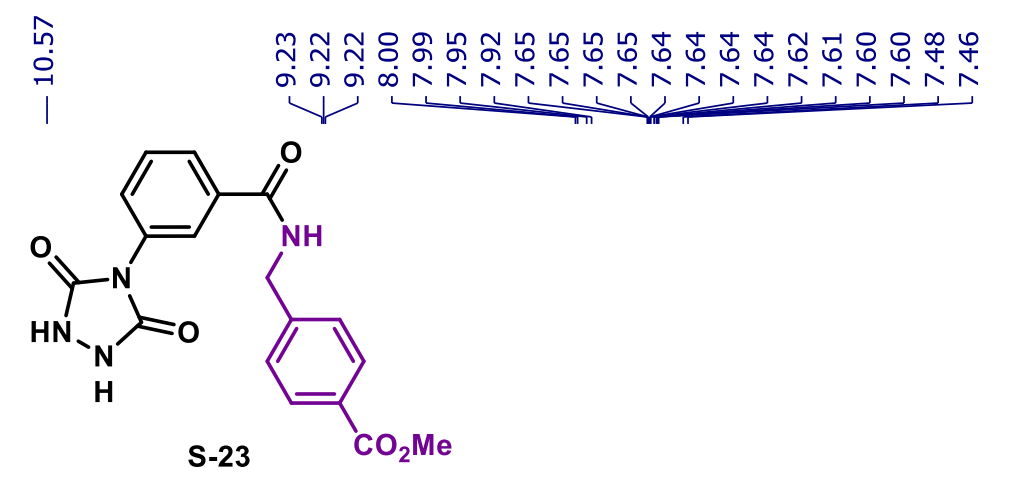

$700 \mathrm{MHz}{ }^{1} \mathrm{H}$ NMR Spectrum of compound S-23 (recorded in DMSO- $d_{6}$ )
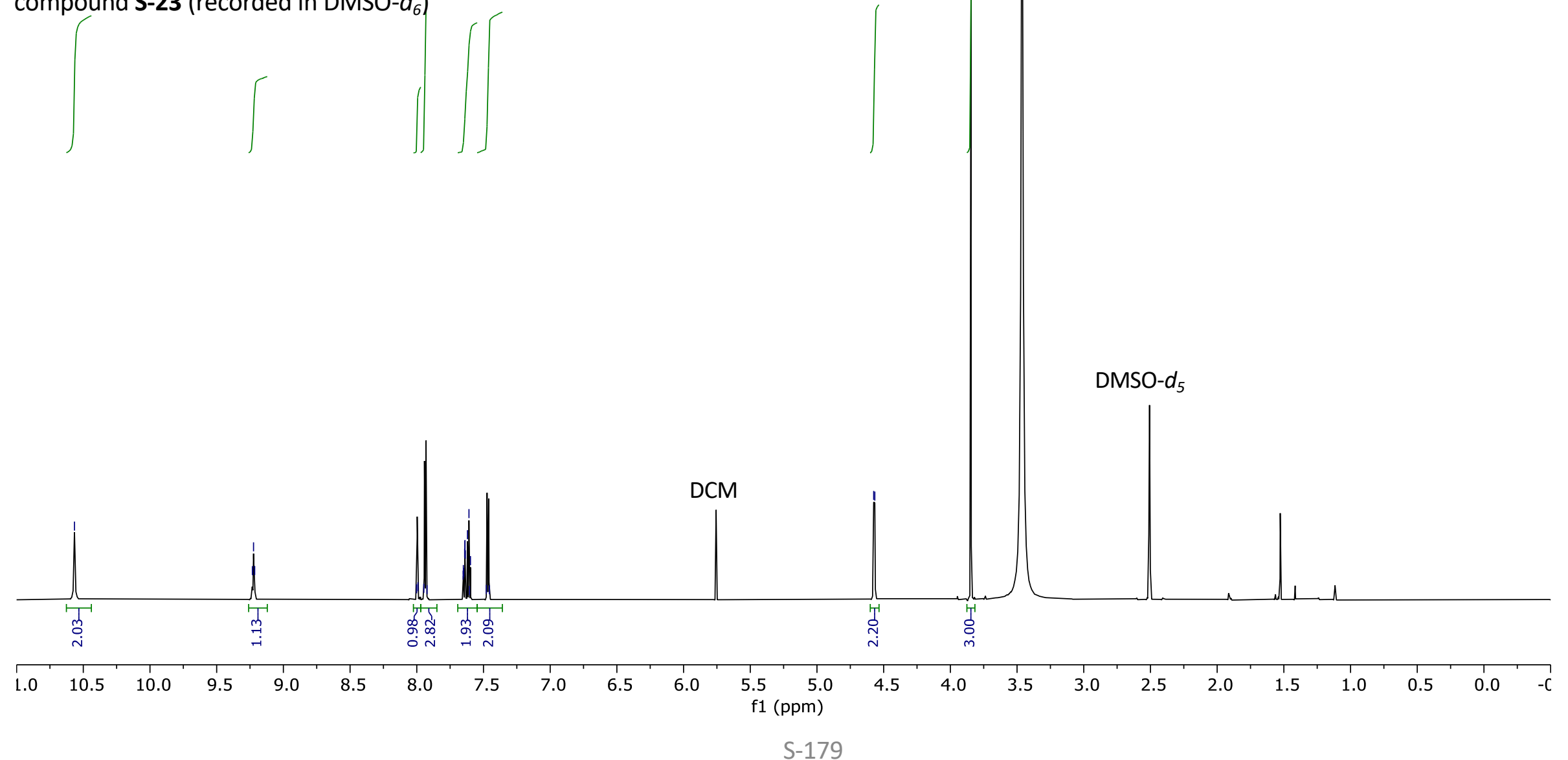

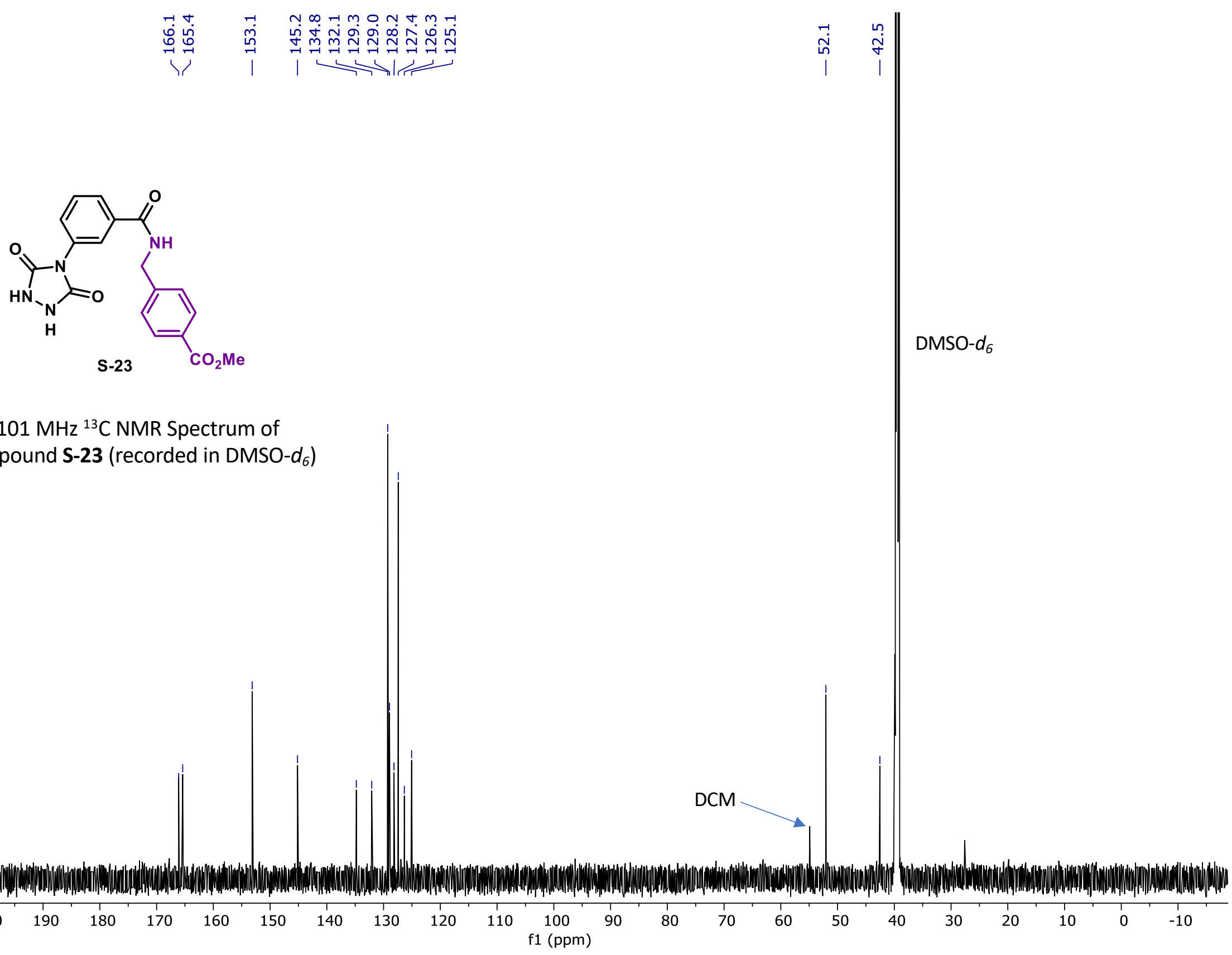

$101 \mathrm{MHz}{ }^{13} \mathrm{C}$ NMR Spectrum of compound S-23 (recorded in DMSO- $d_{6}$ )

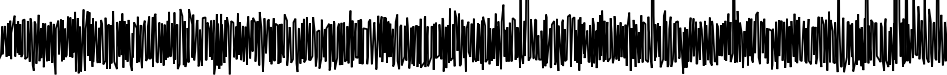
100
$\mathrm{f} 1(\mathrm{ppm})$ 


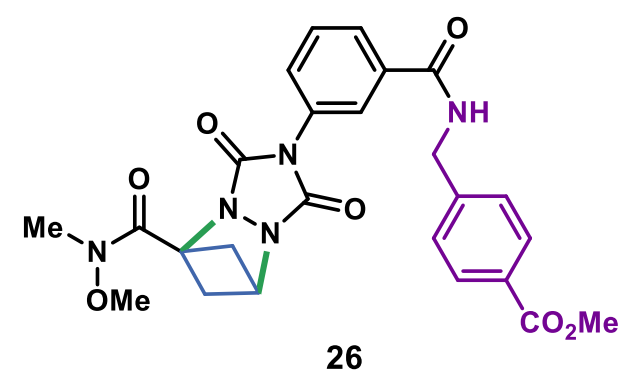

$700 \mathrm{MHz}{ }^{1} \mathrm{H}$ NMR Spectrum of compound 26 (recorded in $\mathrm{CDCl}_{3}$ )

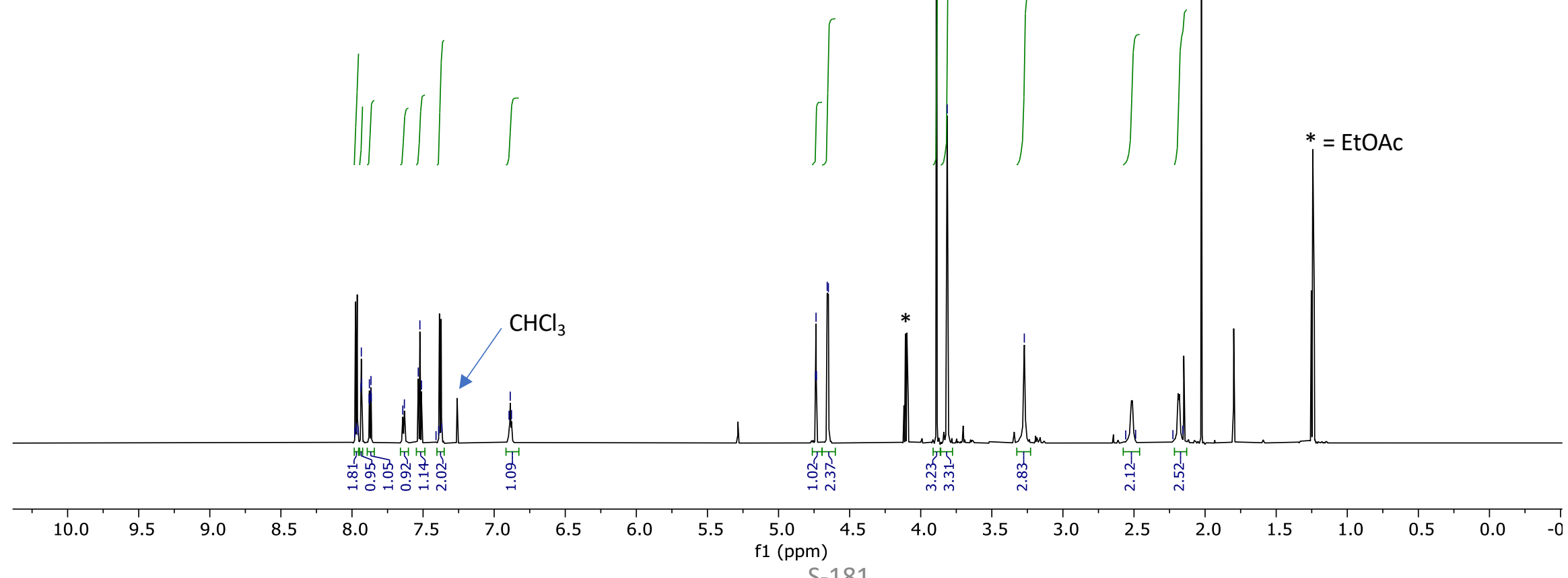




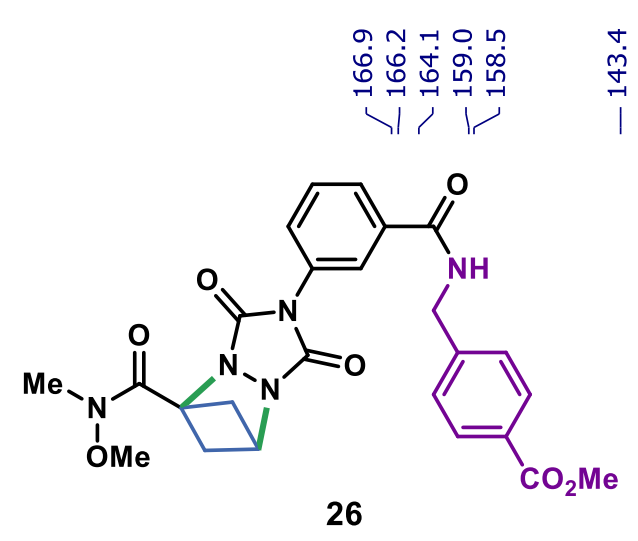

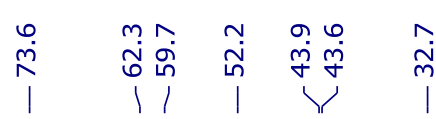

$176 \mathrm{MHz}{ }^{13} \mathrm{C}$ NMR Spectrum of compound $\mathbf{2 6}$ (recorded in $\mathrm{CDCl}_{3}$ )

$\mathrm{CDCl}_{3}$ $=$ EtOAC 


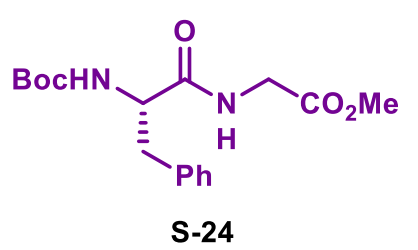

$400 \mathrm{MHz}{ }^{1} \mathrm{H}$ NMR Spectrum of compound S-24 (recorded in $\mathrm{CDCl}_{3}$ )

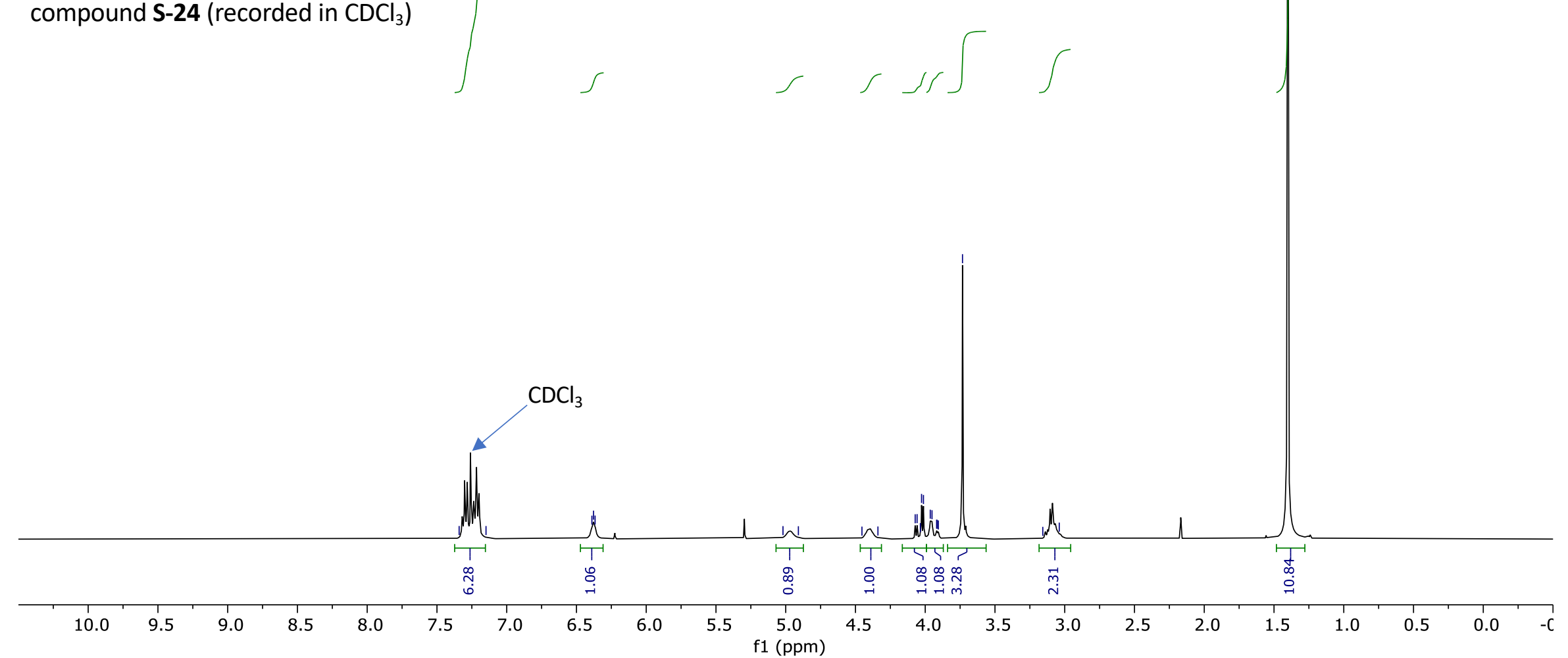




ज̃

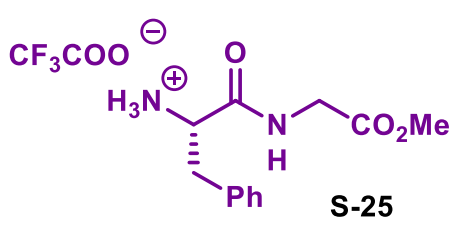

$400 \mathrm{MHz}{ }^{1} \mathrm{H}$ NMR Spectrum of

crude compound S-25 (recorded in DMSO- $d_{6}$ )

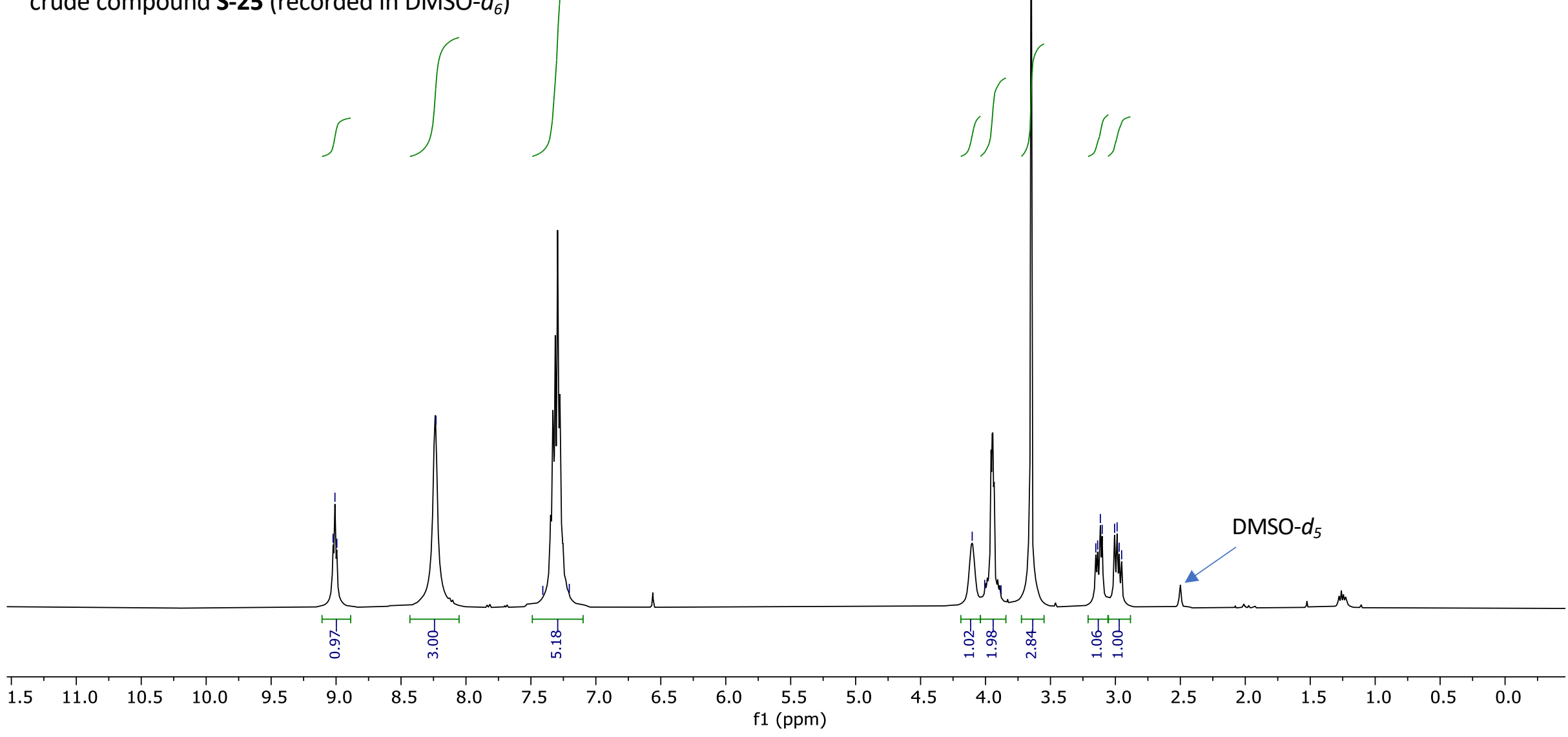




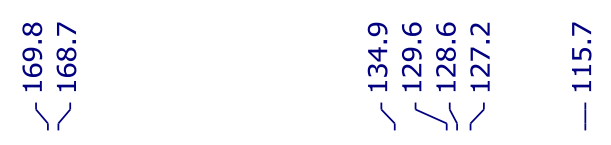

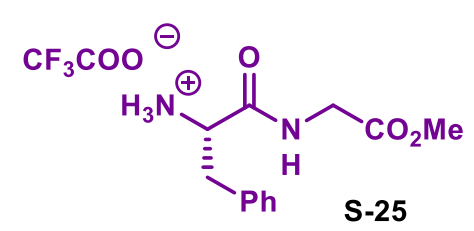

$101 \mathrm{MHz}{ }^{13} \mathrm{C}$ NMR Spectrum of crude compound S-25 (recorded in DMSO- $d_{6}$ )

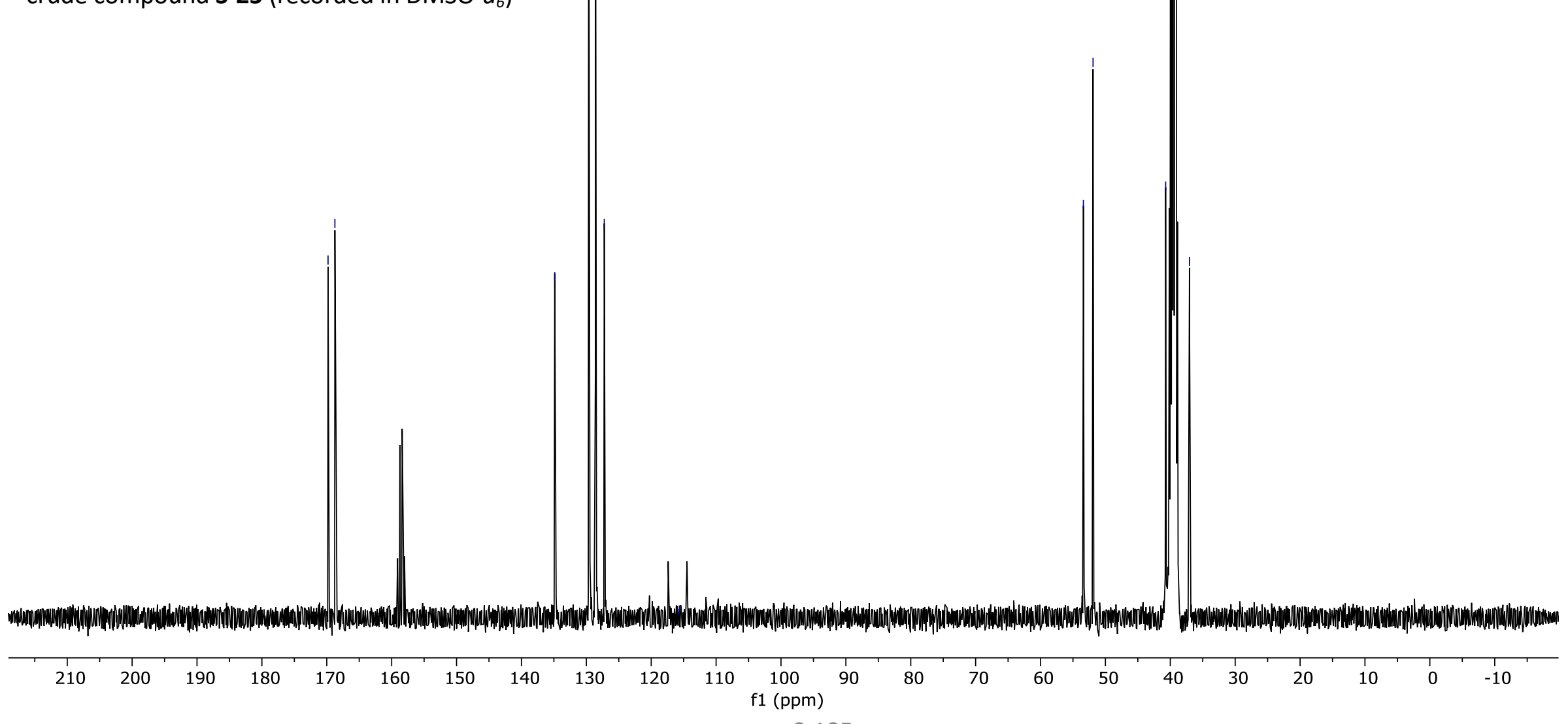




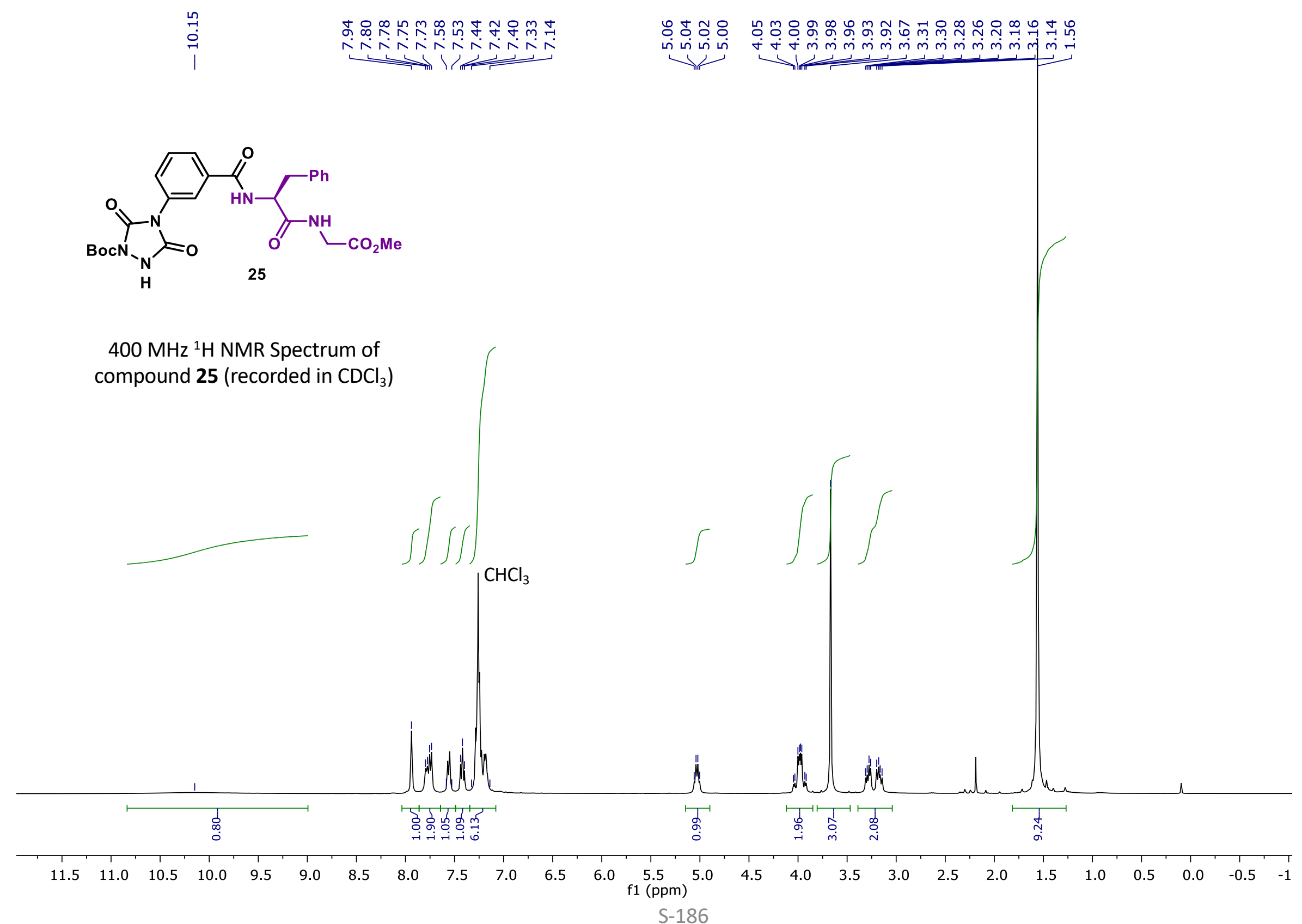




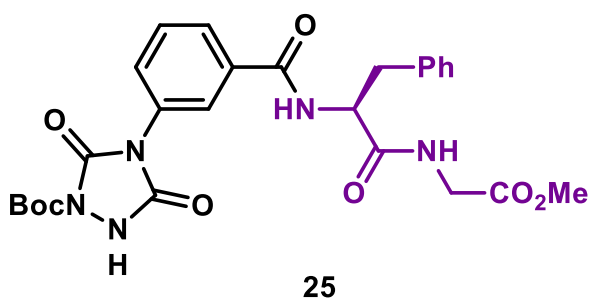

$101 \mathrm{MHz}{ }^{13} \mathrm{C}$ NMR Spectrum of compound $\mathbf{2 5}$ (recorded in $\mathrm{CDCl}_{3}$ )

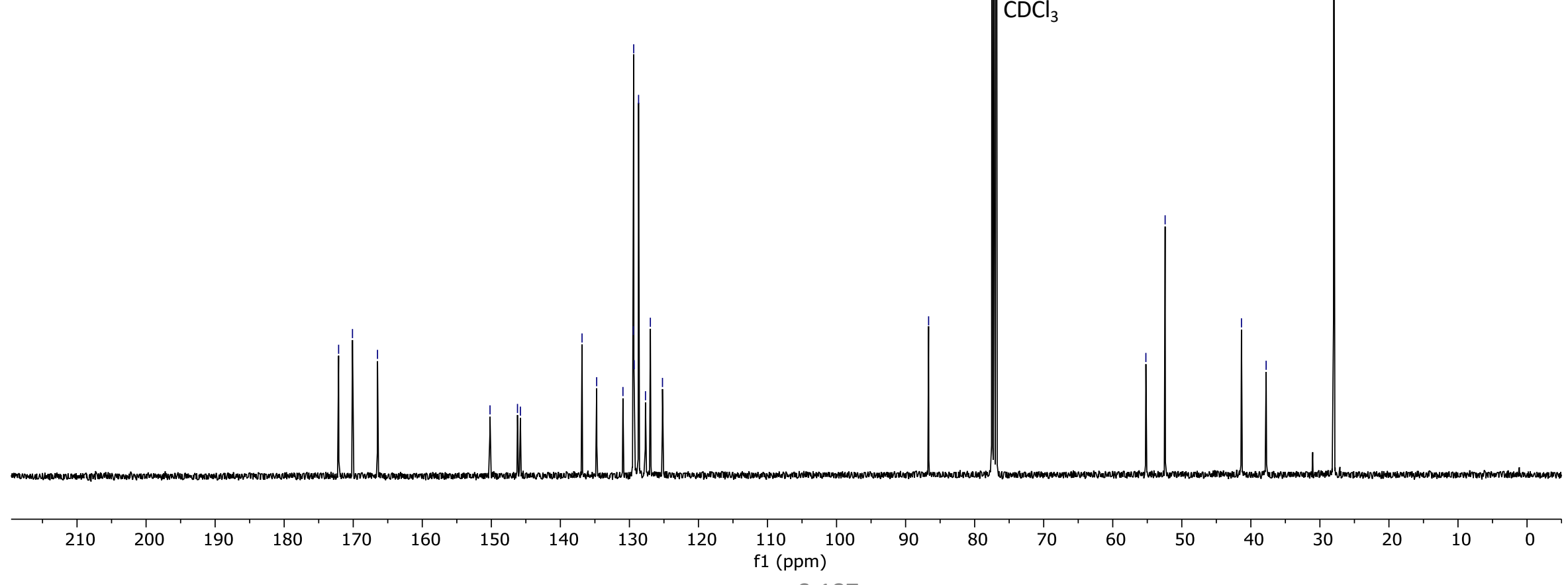




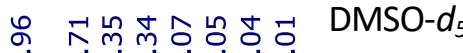

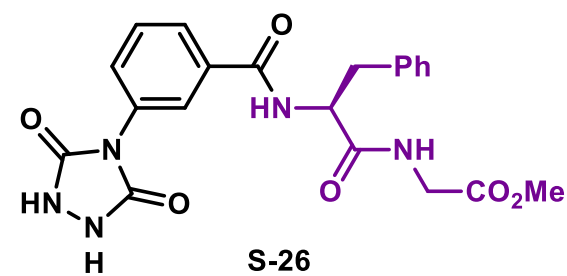

$400 \mathrm{MHz}{ }^{1} \mathrm{H}$ NMR Spectrum of compound S-26 (recorded in Methanol- $\left.d_{4}\right)$
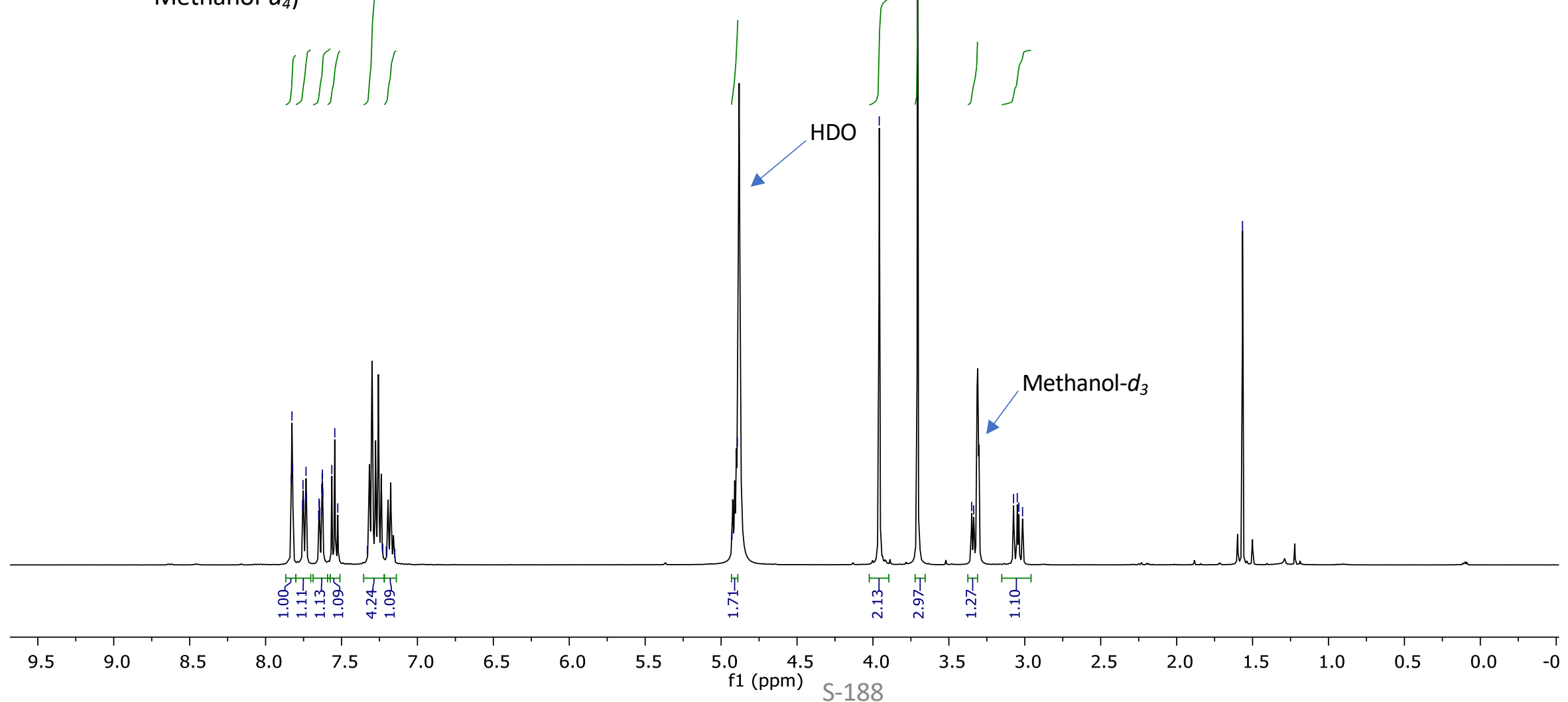


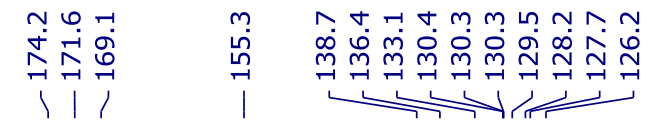<smiles>CC(=O)CNC(=O)C(Cc1ccccc1)NC(=O)c1cccc(-n2c(=O)[nH][nH]c2=O)c1</smiles>

$101 \mathrm{MHz}{ }^{13} \mathrm{C}$ NMR Spectrum of compound S-26 (recorded in Methanol- $d_{4}$ )
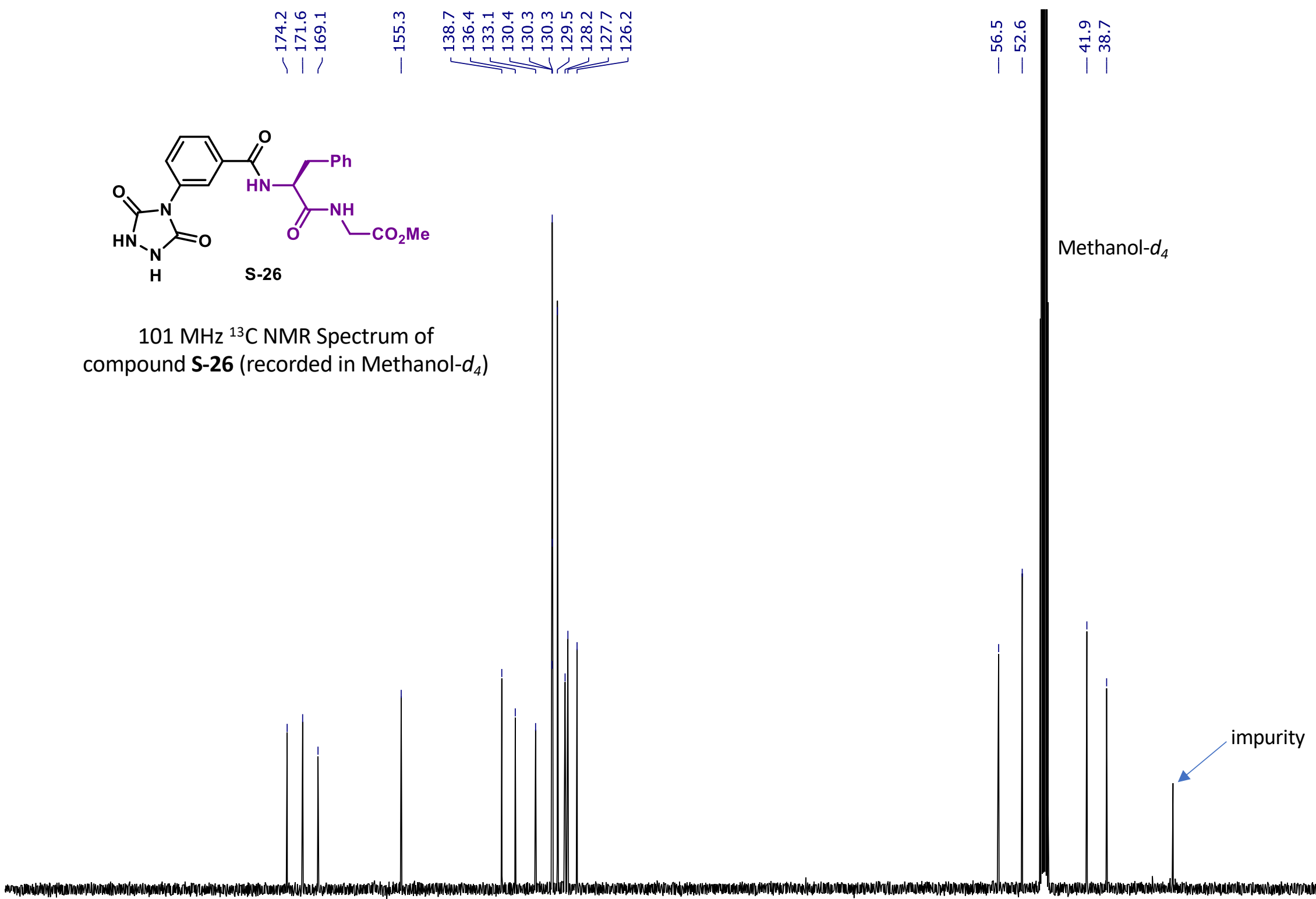


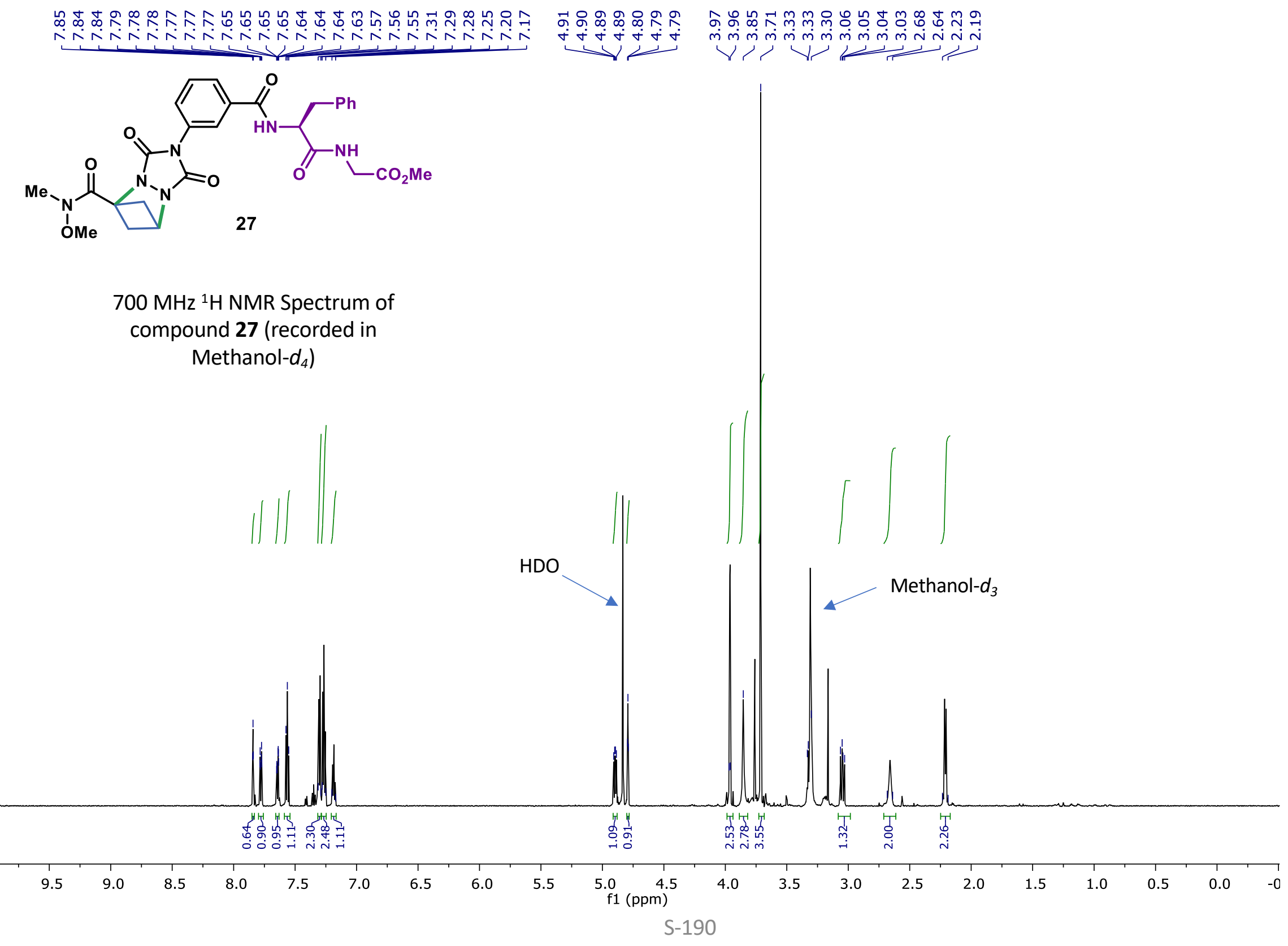




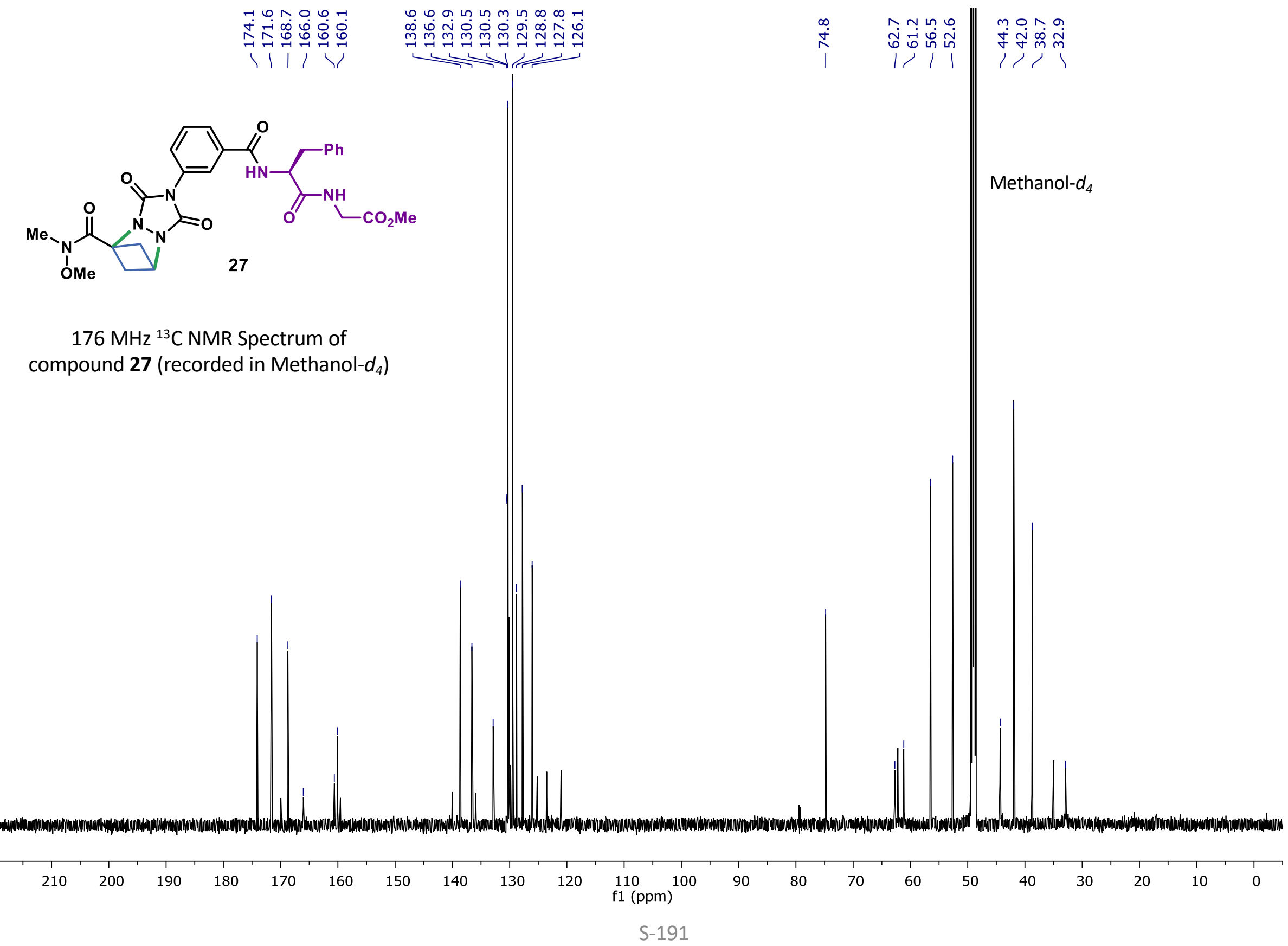

